\begin{tabular}{|c|c|c|c|c|c|c|c|c|}
\hline \multicolumn{3}{|c|}{$\begin{array}{l}\text { 2. To: (Receiving Organization) } \\
\text { Distribution }\end{array}$} & \multicolumn{2}{|c|}{$\begin{array}{l}\text { 3. From: (Originating Organization) } \\
\text { Nuclear Safety }\end{array}$} & \multicolumn{4}{|c|}{ 4. Related EDT No.: } \\
\hline \multicolumn{3}{|c|}{$\begin{array}{l}\text { 5. Proj./Prog./Dept./Div.: } \\
\text { Spent Nuclear Fuel Project }\end{array}$} & \multicolumn{2}{|c|}{$\begin{array}{l}\text { 6. Design Authority/ Design Agent/Cog. } \\
\text { Engr.: } \\
\text { D. M. Black }\end{array}$} & \multicolumn{4}{|c|}{$\begin{array}{r}\text { 7. Purchase Order No.: } \\
\qquad \text { N/A }\end{array}$} \\
\hline \multirow{2}{*}{\multicolumn{5}{|c|}{$\begin{array}{l}\text { 8. Originator Remarks: } \\
\text { N/A }\end{array}$}} & \multicolumn{4}{|c|}{$\begin{array}{r}\text { 9: Equip./Component No.: } \\
\text { N/A }\end{array}$} \\
\hline & & & & & \multicolumn{4}{|c|}{$\begin{array}{r}\text { 10. System/Bldg./Facility: } \\
\text { CSB }\end{array}$} \\
\hline \multirow{3}{*}{\multicolumn{3}{|c|}{ 11. Receiver Remarks: }} & \multirow{3}{*}{\multicolumn{2}{|c|}{ Document? [] Yes [X] No }} & \multicolumn{4}{|c|}{$\begin{array}{r}\text { 12. Major Assm. Dwg. No.: } \\
\text { N/A }\end{array}$} \\
\hline & & & & & \multicolumn{4}{|c|}{$\begin{array}{l}\text { 13. Permit/Permit Application No.: } \\
\text { N/A }\end{array}$} \\
\hline & & & & & \multicolumn{4}{|c|}{$\begin{array}{l}\text { 14. Required Response Date: } \\
\text { N/A }\end{array}$} \\
\hline 15. & \multicolumn{4}{|c|}{ DATA TRANSMITTED } & (F) & (G) & (H) & (I) \\
\hline $\begin{array}{l}(A) \\
\text { Item } \\
\text { No. }\end{array}$ & (B) DocumentDrawing No. & $\begin{array}{l}\text { (C) } \\
\text { Sheet } \\
\text { No. }\end{array}$ & $\begin{array}{l}\text { (D) } \\
\text { Rev. } \\
\text { No. }\end{array}$ & (E) Titic or Description of Data Transmitted & $\begin{array}{l}\text { Approval } \\
\text { Desig- } \\
\text { nator }\end{array}$ & $\begin{array}{l}\text { Reason } \\
\text { for Trans. } \\
\text { mittal }\end{array}$ & $\begin{array}{l}\text { Origi- } \\
\text { nator } \\
\text { Dispo- } \\
\text { sition }\end{array}$ & $\begin{array}{l}\text { Recciv- } \\
\text { er } \\
\text { Dispo- } \\
\text { sition }\end{array}$ \\
\hline 1 & HNF-4742 & & 0 & $\begin{array}{l}\text { Canister Storage Building } \\
\text { Compliance Assessment DOE } \\
\text { Order } 6430.1 \mathrm{~A}, \text { General } \\
\text { Design Criteria }\end{array}$ & $\mathrm{S}$ & 2 & $\overline{\mathrm{N} / \mathrm{A}}$ & N/A \\
\hline & & & & & & & & \\
\hline & & & & & & & & \\
\hline & & & & & & & & \\
\hline & & & & & & & & \\
\hline & & & & & & & & \\
\hline
\end{tabular}

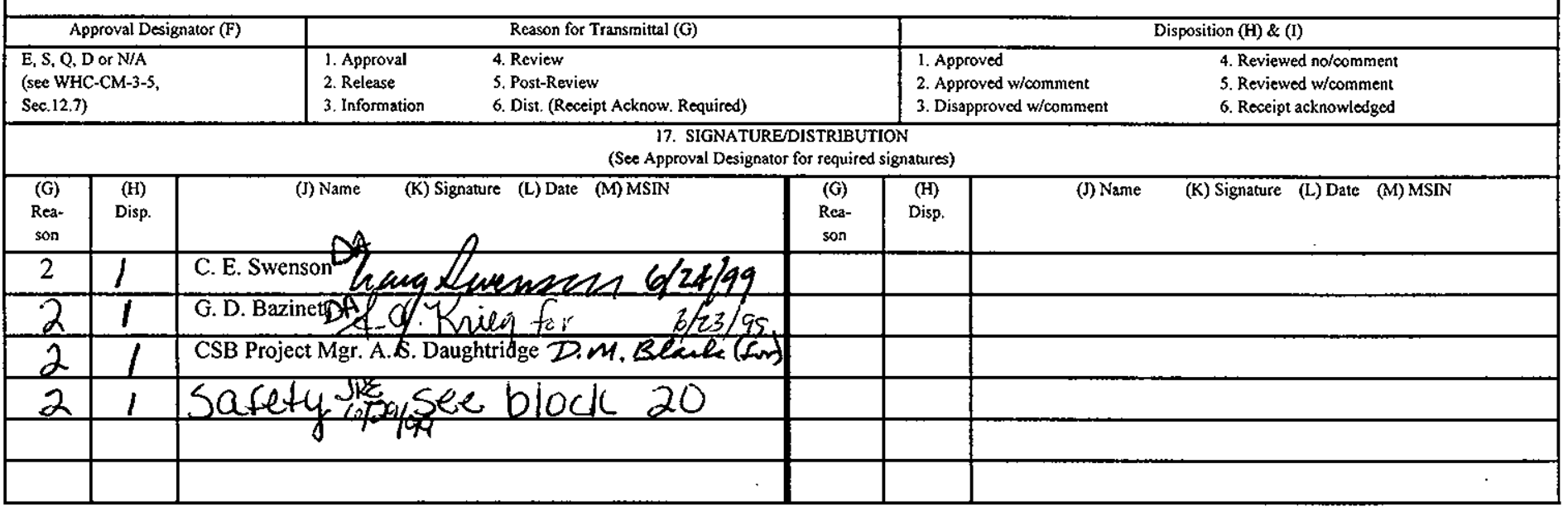

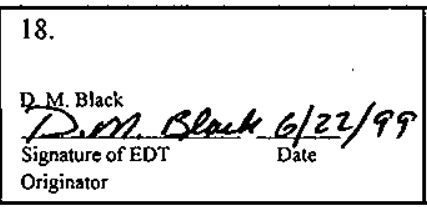

19.

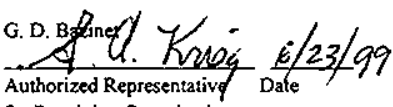

for Receiving Organization
20.

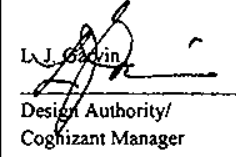

21. DOE APPROVAL (if required)

Ctrl. No.

[] Approved

[] Approved w/comments

[] Disapproved w/comments 


\section{Canister Storage Building Compliance Assessment DOE Order 6430.1A, General Design Criteria}

D. M. Black

Fluor Daniel Northwest, Inc., Richland, WA 99352

U.S. Department of Energy Contract DE-AC06-96RL13200

EDT/ECN: 626885

Org Code: 2 F200

B\&R Code: 39EW40400
UC: 620

Charge Code: $105625 / \mathrm{CB} 80$

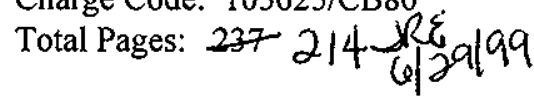

Key Words: Spent Nuclear Fuel Project, Canister Storage Building, Compliance Assessment

Abstract: This document presents the Project's position on compliance with DOE Order $6430.1 \mathrm{~A}$ "General Design Criteria." No non-compliances are shown. The compliance statements have been reviewed and approved by DOE. Open items are scheduled to be closed prior to project completion.

TRADEMARK DISCLAIMER. Reference herein to any specific commercial product, process, or service by trade name, trademark, manufacturer, or otherwise, does not necessarily constitute or imply its endorsement, recommendation, or favoring by the United States Government or any agency thereof or its contractors or subcontractors.

Printed in the United States of America. To obtain copies of this document, contact: Document Control Services, P.O. Box 950, Mailstop H6-08, Richland WA 99352, Phone (509) 372-2420; Fax (509) 376-4989.
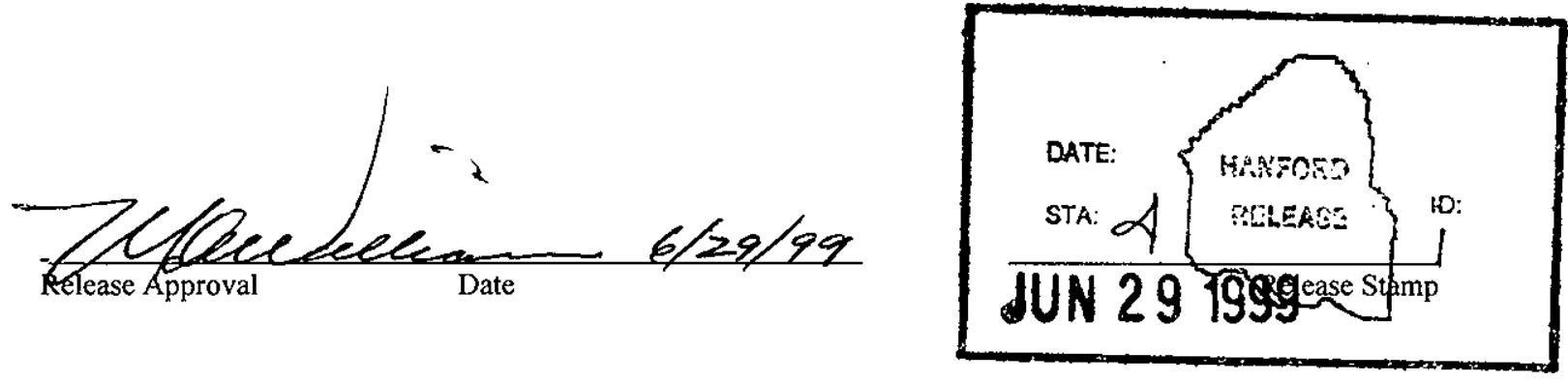

\section{Approved for Public Release}




\section{Canister Storage Building Compliance Assessment DOE Order 6430.1A, General Design Criteria}

HNF-4742, Rev. 0

\begin{tabular}{|c|c|c|c|c|}
\hline $\begin{array}{l}\text { Applicable } \\
\text { Section }\end{array}$ & $\begin{array}{c}\text { Item } \\
\#\end{array}$ & Criteria & Status & Implementation \\
\hline $0110-5$ & & Health and Safety & & \\
\hline $0110-5.1$ & 1. & $\begin{array}{l}\text { Specific project design criteria in the areas of } \\
\text { emergency preparedness and emergency } \\
\text { management shall be developed with the advice and } \\
\text { assistance of DOE organizations responsible for } \\
\text { DOE emergency management/emergency } \\
\text { preparedness programs. Such criteria shall comply } \\
\text { with: } \\
\qquad \begin{array}{l}\text { - DOE } 5500.1 \mathrm{~A} \\
\quad \text { DOE } 5500.3 \text {. }\end{array}\end{array}$ & $\mathrm{C}$ & $\begin{array}{l}\text { The CSB FSAR contains emergency preparedness sections in } \\
\text { accordance with DOE } 3009 \text {. (Ref: HNF- } 3553 \text {, Rev } 0 \text {, Chapters } \\
15.0 \text { and A15.0). The emergency response organization meets the } \\
\text { requirements set forth in the DOE } 5500 \text {-series orders and other } \\
\text { applicable state and federal regulations through DOE/RL-94-02, } \\
\text { Hanford Site Emergency Response Plan. }\end{array}$ \\
\hline $0110-5.2$ & & Safety Analysis & & \\
\hline $0110-5.2$ & 2. & $\begin{array}{l}\text { All DOE facilities shall be evaluated for potential } \\
\text { risks to the operators, the public, and the } \\
\text { environment. }\end{array}$ & $\mathrm{C}$ & $\begin{array}{l}\text { The CSB FSAR contains sections that evaluate the facility for } \\
\text { potential risks to the operator, the public and the environment. } \\
\text { (Ref: HNF-3553, Rev 0, Chapters } 3.0 \text { and A3.0). }\end{array}$ \\
\hline $0110-5.2$ & 3. & $\begin{array}{l}\text { The FSAR shall be updated as appropriate to reflect } \\
\text { changes affecting safety that are made to the facility } \\
\text { during its lifetime. }\end{array}$ & $\mathrm{C}$ & $\begin{array}{l}\text { As discussed in the CSB FSAR the system used to develop an } \\
\text { authorization basis document, evaluating and controlling changes, } \\
\text { and implementing the authorization basis is the Authorization Basis } \\
\text { Management System. (Ref: HNF-3553, Rev 0, Section 17.4.3.2.3). }\end{array}$ \\
\hline $0110-5.3$ & & Emergency Preparedness Planning & & \\
\hline
\end{tabular}




\section{Canister Storage Building Compliance Assessment DOE Order 6430.1A, General Design Criteria}

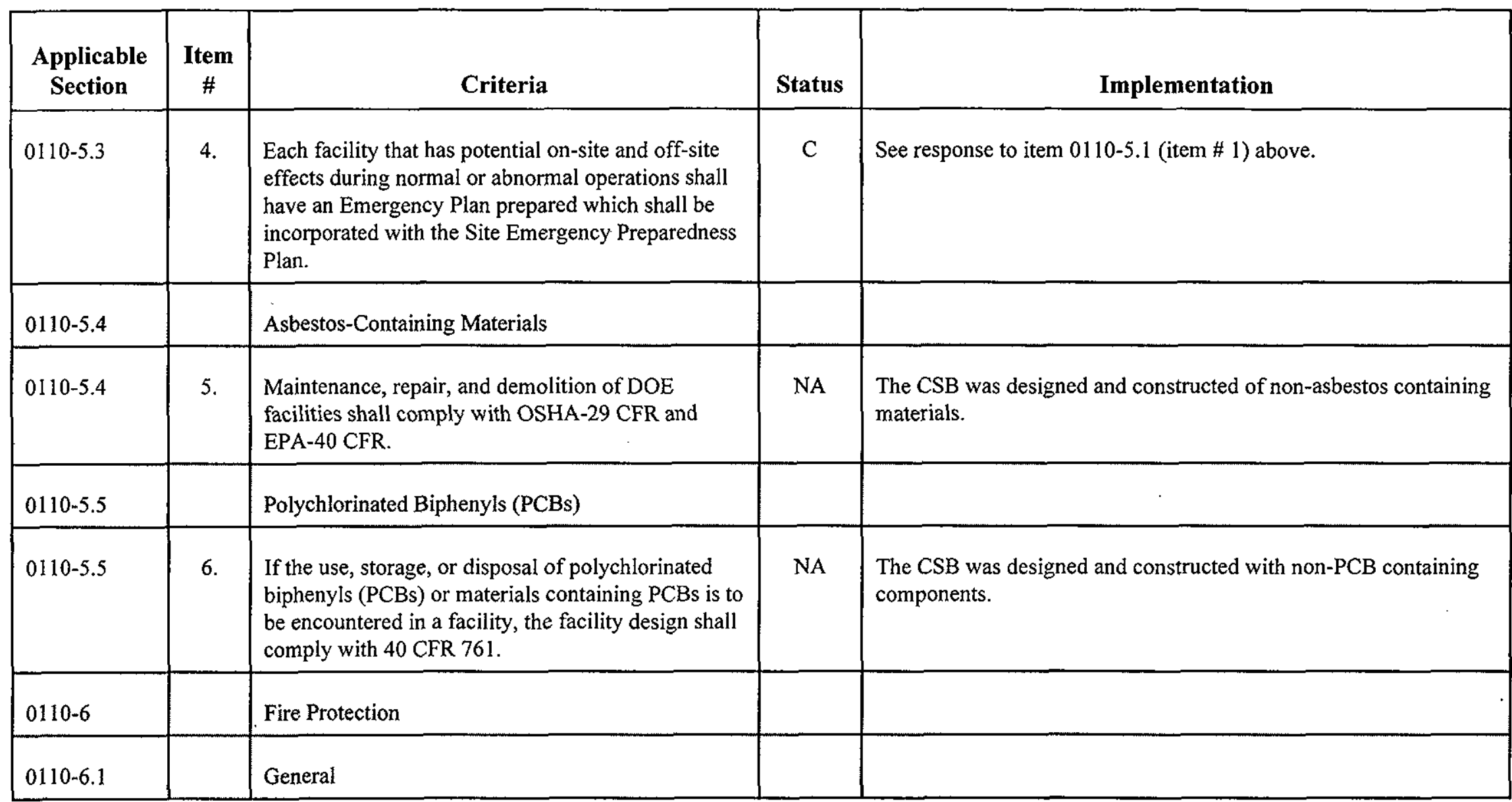




\section{Canister Storage Building Compliance Assessment DOE Order 6430.1A, General Design Criteria}

\begin{tabular}{|c|c|c|c|c|}
\hline $\begin{array}{l}\text { Applicable } \\
\text { Section }\end{array}$ & $\begin{array}{l}\text { Item } \\
\#\end{array}$ & Criteria & Status & Implementation \\
\hline $0110-6.1$ & 8. & $\begin{array}{l}\text { Facilities shall also comply with } 29 \text { CFR } 1926 \text { and } \\
\text { CFR } 1910 \text {. Except as required by other sections of } \\
\text { these criteria, NFPA } 101 \text { shall apply where } 29 \text { CFR } \\
1926 \text { and } 29 \text { CFR } 1910 \text { does not apply or where } \\
\text { NFPA } 101 \text { exceeds the requirements of } 29 \text { CFR } \\
1926 \text { and } 29 \text { CFR } 1910 \text {. }\end{array}$ & $\mathrm{C}$ & $\begin{array}{l}\text { CSB facility design is consistent with NFPA } 101 \text { for life safety and } \\
\text { NFPA } 220 \text { for types of construction. (Ref: FDH-9655218). See: } \\
\text { Performance Specification for the Spent Nuclear Fuel Canister } \\
\text { Storage Building, HNF-S-0425, Rev. } 3 \text {. }\end{array}$ \\
\hline $0110-6.1$ & 10. & $\begin{array}{l}\text { Any materials with unusual fire characteristics such } \\
\text { as urethane foams, and any materials that develop } \\
\text { significant quantities of toxic or other harmful } \\
\text { products of combustion, shall not be used as interior } \\
\text { finishes or other interior applications without the } \\
\text { approval of the cognizant DOE fire protection } \\
\text { authority. }\end{array}$ & NA & $\begin{array}{l}\text { The CSB design does not use any materials with unusual fire } \\
\text { characteristics. Only the MHM neutron absorbing material } \\
\text { (Jabroc }^{\mathrm{TM}} \text { ) has unique properties. No combustion products with } \\
\text { hazardous properties beyond those normally associated with } \\
\text { burning wood products are identified for this material. The } \\
\text { material does not burn freely. A flame spread test per UL } 723 \text { to } \\
\text { demonstrate a flame spread rating of } 25 \text { or less has been performed } \\
\text { ( } 0.8 \text { actual). (Ref: Appendix } 5 \text { of ESL/R(96)065-Rev D). }\end{array}$ \\
\hline $0110-6.1$ & 11. & $\begin{array}{l}\text { The use of foamed plastics in construction shall be } \\
\text { prohibited unless it fully complies with FM 1-57. }\end{array}$ & NA & The CSB design and construction does not utilize foamed plastics. \\
\hline
\end{tabular}




\section{Canister Storage Building Compliance Assessment \\ DOE Order 6430.1A, General Design Criteria}

HNF-4742, Rev. 0

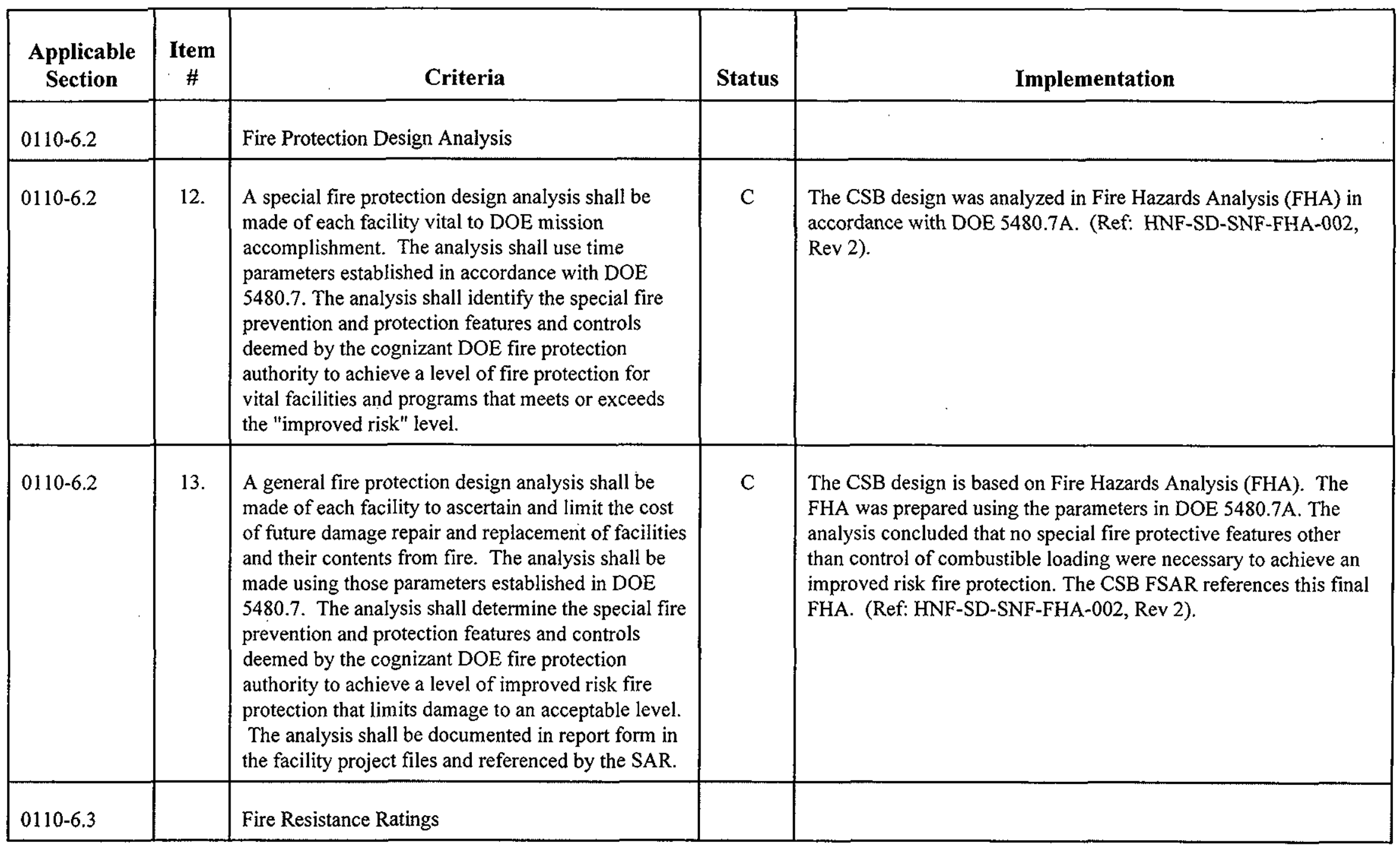




\section{Canister Storage Building Compliance Assessment \\ DOE Order 6430.1A, General Design Criteria}

HNF-4742, Rev. 0

\begin{tabular}{|c|c|c|c|c|}
\hline $\begin{array}{l}\text { Applicable } \\
\text { Section }\end{array}$ & $\begin{array}{c}\text { Item } \\
\#\end{array}$ & Criteria & Status & Implementation \\
\hline $0110-6.3$ & 15. & $\begin{array}{l}\text { Wall, floor and ceiling, and roof and ceiling } \\
\text { assemblies shall be tested and rated for their fire } \\
\text { resistance by UL or similar nationally accredited } \\
\text { testing laboratories, or shall be listed for their fire } \\
\text { resistance as approved by FM or similar national } \\
\text { insurance organizations. }\end{array}$ & $\mathrm{C}$ & $\begin{array}{l}\text { The CSB utilizes fire rated assemblies at penetrations through the } \\
\text { 2-hour fire rated wall between the support and operations area } \\
\text { buildings. These assemblies are rated and labeled in accordance } \\
\text { with UL or FM. (Ref: HNF-3553, Section A2.7.1). }\end{array}$ \\
\hline $0110-6.4$ & & Hazardous Areas & & \\
\hline $0110-6.4$ & 16. & $\begin{array}{l}\text { Hazardous areas, such as radioactive spaces or } \\
\text { spaces with inert atmospheres, shall have sufficient } \\
\text { alarms and interlocks to assure that access by } \\
\text { emergency personnel will not endanger such } \\
\text { personnel or result in a public hazard. }\end{array}$ & $\mathrm{C}$ & $\begin{array}{l}\text { The CSB design for the storage and handling of MCOs precludes } \\
\text { access by individuals to areas where high radiation levels or inert } \\
\text { gas atmospheres are present. Areas of high radiation such as the } \\
\text { below grade vault are not accessible by personnel. MHM interlocks } \\
\text { prevent the MHM from leaving a storage tube without first } \\
\text { replacing the shield plug. (Ref: HNF-3553, Section A2.5.1.3). }\end{array}$ \\
\hline
\end{tabular}




\section{Canister Storage Building Compliance Assessment DOE Order 6430.1A, General Design Criteria}

HNF-4742, Rev. 0

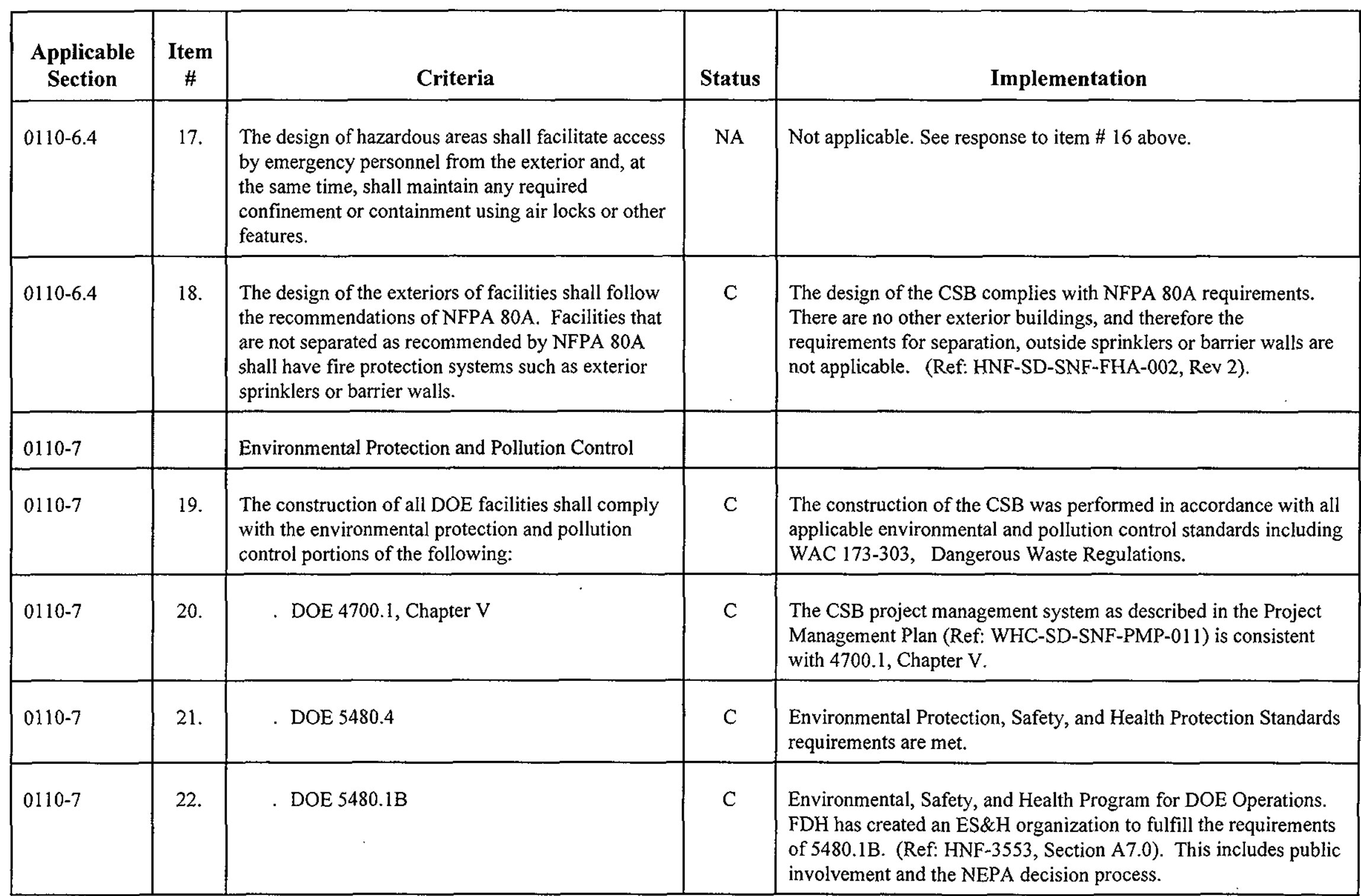




\section{Canister Storage Building Compliance Assessment \\ DOE Order 6430.1A, General Design Criteria}

HNF-4742, Rev. 0

\begin{tabular}{|c|c|c|c|c|}
\hline $\begin{array}{l}\text { Applicable } \\
\text { Section }\end{array}$ & $\begin{array}{l}\text { Item } \\
\#\end{array}$ & Criteria & Status & Implementation \\
\hline $0110-12$ & & Energy Conservation & & \\
\hline $0110-12.2$ & & General & & \\
\hline $0110-12.2$ & 24. & $\begin{array}{l}\text { For existing construction, ASHRAE Standard } 100 \\
\text { shall apply }\end{array}$ & NA & Not applicable. The CSB is new construction. \\
\hline $0110-13$ & & Physical Protection & & \\
\hline $0110-13.2$ & & Access Control and Security Areas & & \\
\hline $0110-13.2 .1$ & & General & & \\
\hline $0110-13.2 .1$ & 26. & $\begin{array}{l}\text { Controls shall be established to prevent } \\
\text { unauthorized access to security areas or removal of } \\
\text { security interests. In general, the following apply: }\end{array}$ & $\mathrm{C}$ & $\begin{array}{l}\text { The CSB provides physical protection for the SNF stored in MCOs } \\
\text { by providing intrusion barriers at the entrances to the operating } \\
\text { area and below grade vault. The below grade vault and the service } \\
\text { and sampling/welding pits are protected areas. The operating area } \\
\text { is a limited area. (Ref: CSB Vulnerability Assessment). }\end{array}$ \\
\hline
\end{tabular}




\section{Canister Storage Building Compliance Assessment \\ DOE Order 6430.1A, General Design Criteria}

HNF-4742, Rev. 0

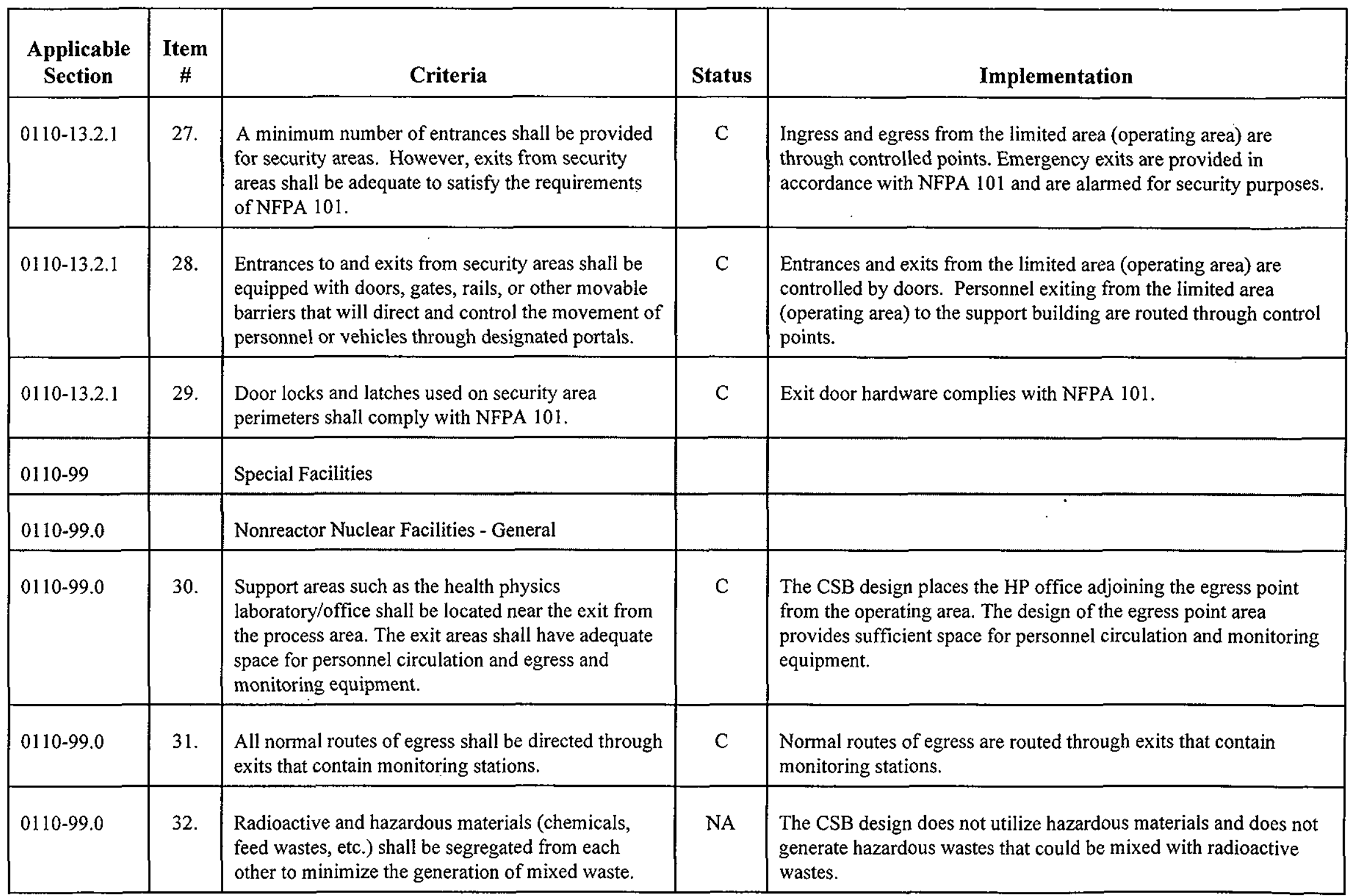




\section{Canister Storage Building Compliance Assessment \\ DOE Order 6430.1A, General Design Criteria}

HNF-4742, Rev. 0

\begin{tabular}{|c|c|c|c|c|}
\hline $\begin{array}{l}\text { Applicable } \\
\text { Section }\end{array}$ & $\begin{array}{l}\text { Item } \\
\#\end{array}$ & Criteria & Status & Implementation \\
\hline $0110-99.0 .2$ & 34. & $\begin{array}{l}\text { Special facilities services and building utilities shall } \\
\text { beplanned to achieve maximum flexibility and ease } \\
\text { of access. }\end{array}$ & $\mathrm{C}$ & $\begin{array}{l}\text { The CSB design provides utilities services at all anticipated use } \\
\text { locations. For example, service air and electrical power are } \\
\text { provided at various locations in the operating area. Maximum } \\
\text { flexibility and ease of access to utilities is thereby achieved. }\end{array}$ \\
\hline $0110-99.0 .2$ & 36. & $\begin{array}{l}\text { Establishment of zones (space) in vertical and } \\
\text { horizontal service chases }\end{array}$ & NA & $\begin{array}{l}\text { Not applicable. There are no horizontal or vertical service chases in } \\
\text { the CSB design. }\end{array}$ \\
\hline $0110-99.0 .2$ & 37. & Determination of service header sizes & NA & Not applicable, see response to item $\# 35$, above. \\
\hline $0110-99.0 .2$ & 38. & Assignment of spaces & NA & $\begin{array}{l}\text { Not applicable, there are no gravity flow piped services for which } \\
\text { space assignment is required. }\end{array}$ \\
\hline $0110-99.0 .2$ & 39. & $\begin{array}{l}\text { Vertical chases shall be provided with fire cutoffs, } \\
\text { preferably at each floor level and at the enclosing } \\
\text { partitions, consistent with the building construction } \\
\text { code classification. }\end{array}$ & NA & Not applicable. There are no vertical chases in the CSB design. \\
\hline
\end{tabular}




\section{Canister Storage Building Compliance Assessment \\ DOE Order 6430.1A, General Design Criteria}

HNF-4742, Rev. 0

\begin{tabular}{|c|c|c|c|c|}
\hline $\begin{array}{l}\text { Applicable } \\
\text { Section }\end{array}$ & $\begin{array}{c}\text { Item } \\
\#\end{array}$ & Criteria & Status & Implementation \\
\hline $0110-99.0 .2$ & 42. & $\begin{array}{l}\text { Compressed gas cylinders shall be isolated outside } \\
\text { of the special facilities building or housed in a } \\
\text { special hazardous materials storage room, exhausted } \\
\text { gas cabinets, or similar types of containment. }\end{array}$ & $\mathrm{C}$ & $\begin{array}{l}\text { Housing of compressed gas cylinders is outside of the operating } \\
\text { area building. Compressed gas cylinders used in the operating area } \\
\text { building are required to be provided with flow restricting devices } \\
\text { to prevent them from becoming dangerous missiles in the event of } \\
\text { an accidental drop. The cylinders are securely mounted to the } \\
\text { Tube Vent and Purge Cart. (Ref: HNF-3553, Chapter A3.0). }\end{array}$ \\
\hline $0110-99.0 .2$ & 43. & $\begin{array}{l}\text { To ensure both the safety of personnel and the } \\
\text { effective administration and control of special } \\
\text { facilities, access to hazardous areas (e.g., hazardous } \\
\text { gas storage locations and electrical power and } \\
\text { distribution panels) shall be controlled by locked } \\
\text { gates, doors, power panels, or other physical } \\
\text { barriers. }\end{array}$ & $\mathrm{C}$ & $\begin{array}{l}\text { Access to potentially hazardous locations controlled by locked } \\
\text { doors and panels to electrical power and safely stored compressed } \\
\text { gas cylinders. }\end{array}$ \\
\hline $0110-99.0 .2$ & 44. & $\begin{array}{l}\text { Where continuous services are required, service } \\
\text { headers shall be looped and appropriately valved to } \\
\text { maintain such services during routine maintenance } \\
\text { or systems alterations. }\end{array}$ & NA & $\begin{array}{l}\text { No utility services requiring continuous operation have been } \\
\text { identified for the CSB. }\end{array}$ \\
\hline
\end{tabular}




\section{Canister Storage Building Compliance Assessment DOE Order 6430.1A, General Design Criteria}

HNF-4742, Rev. 0

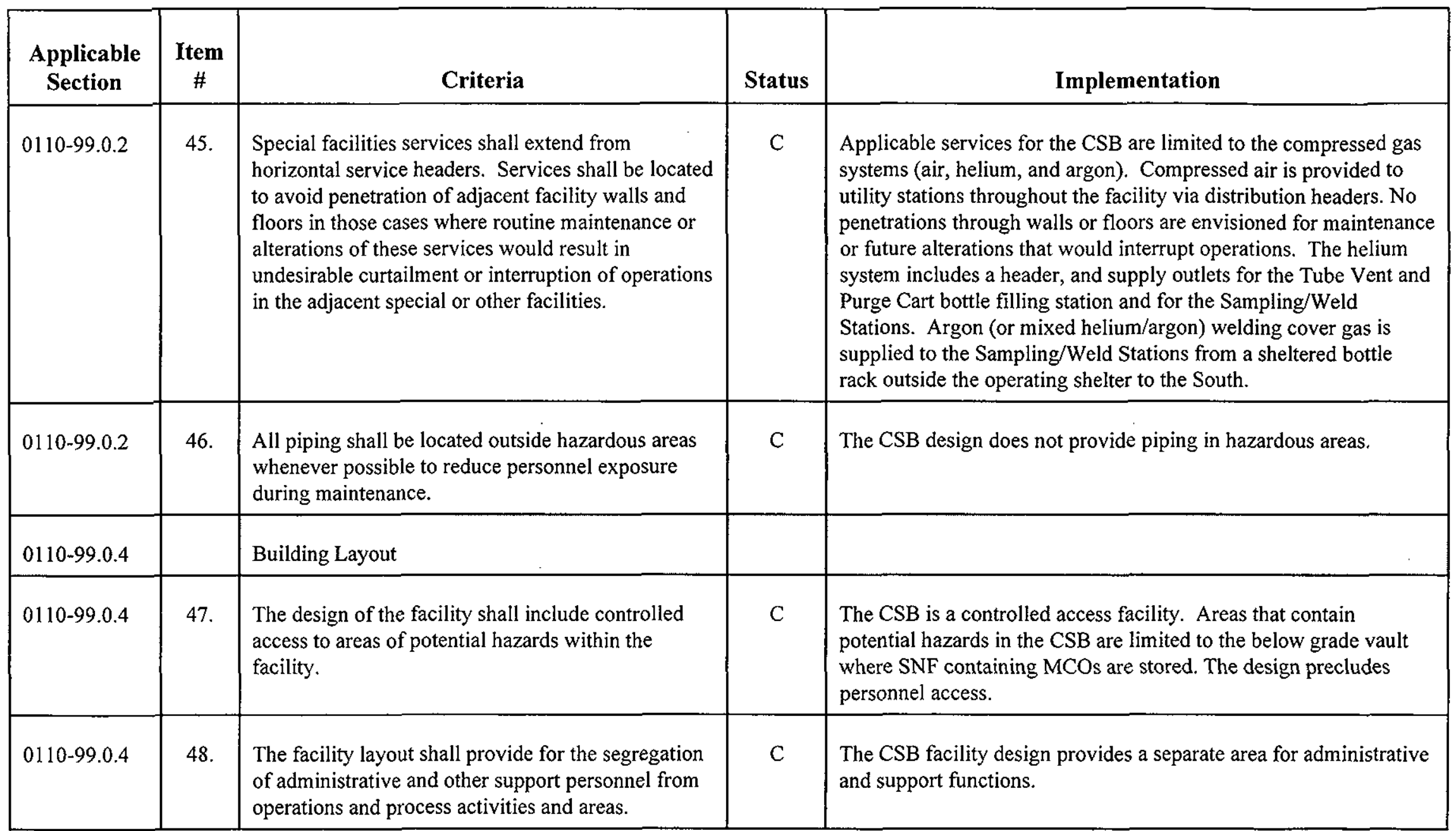




\section{Canister Storage Building Compliance Assessment \\ DOE Order 6430.1A, General Design Criteria}

HNF-4742, Rev. 0

\begin{tabular}{|c|c|c|c|c|}
\hline $\begin{array}{l}\text { Applicable } \\
\text { Section }\end{array}$ & $\begin{array}{c}\text { Item } \\
\#\end{array}$ & Criteria & Status & Implementation \\
\hline $0110-99.0 .4$ & 50. & $\begin{array}{l}\text { The design shall protect workers sufficiently from } \\
\text { hazards to ensure that workers can perform actions } \\
\text { required during normal operations, anticipated } \\
\text { operational occurrences and postulated DBAs. }\end{array}$ & $\mathrm{C}$ & $\begin{array}{l}\text { The CSB design protects workers from hazards during normal or } \\
\text { anticipated occurrences, or DBAs. (Ref: HNF-3553, Section } \\
\text { A3.3.3). }\end{array}$ \\
\hline $0110-99.0 .4$ & 51. & $\begin{array}{l}\text { The design shall ensure prompt, safe shutdown in } \\
\text { emergencies and allow ready access to areas where } \\
\text { manual corrective actions are required and to areas } \\
\text { that contain radiation monitoring equipment. }\end{array}$ & $\mathrm{C}$ & $\begin{array}{l}\text { MCO handling equipment in the CSB is provided with emergency } \\
\text { shutdowns. Seismic detection and automatic shutdown is provided } \\
\text { for the cranes in accordance with ASME NOG-1. Radiation } \\
\text { monitoring equipment is located in easily accessed areas of the } \\
\text { support building and operating area. The CSB is designed to place } \\
\text { all equipment in a safe status upon loss of power. }\end{array}$ \\
\hline $0110-99.0 .4$ & 52. & $\begin{array}{l}\text { A minimum number of entrances shall be provided } \\
\text { for security areas. However, exits shall comply } \\
\text { with NFPA } 101 \text {. Some exits shall be provided for } \\
\text { emergency use only, and equipped with alarm } \\
\text { devices and seals. }\end{array}$ & $\mathrm{C}$ & $\begin{array}{l}\text { The CSB design is provided with limited entrances for security and } \\
\text { safeguards reasons. Exits are provided with alarms. See response } \\
\text { to } 6430.1 \mathrm{~A} \text {, Section } 0110-13.2 .1 \text { above (item \# 27). }\end{array}$ \\
\hline $0110-99.0 .4$ & 53. & $\begin{array}{l}\text { At least two exits shall be provided in rooms where } \\
\text { hazardous materials are handled. (Exceptions for } \\
\text { explosives facilities appear in Chapter II, Section } \\
2.2 \text {, of DOE/EV 06194.) }\end{array}$ & NA & $\begin{array}{l}\text { The CSB operation does not involve direct handling of hazardous } \\
\text { materials. Exits are provided in accordance with NFPA } 101 \text {. }\end{array}$ \\
\hline
\end{tabular}




\section{Canister Storage Building Compliance Assessment DOE Order 6430.1A, General Design Criteria}

HNF-4742, Rev. 0

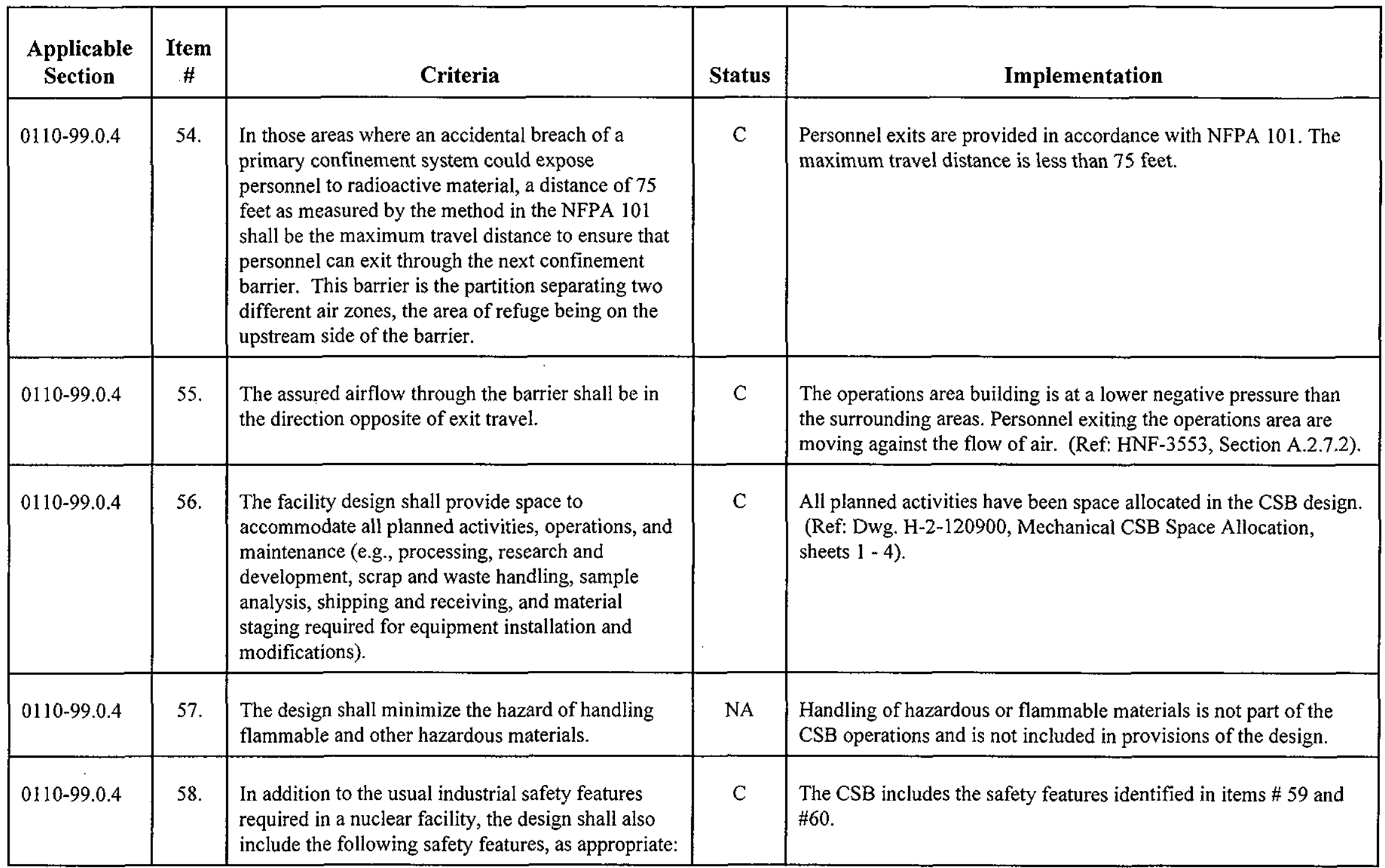




\section{Canister Storage Building Compliance Assessment \\ DOE Order 6430.1A, General Design Criteria}

HNF-4742, Rev. 0

\begin{tabular}{|c|c|c|c|c|}
\hline $\begin{array}{l}\text { Applicable } \\
\text { Section }\end{array}$ & $\begin{array}{c}\text { Item } \\
\#\end{array}$ & Criteria & Status & Implementation \\
\hline $0110-99.0 .4$ & 60. & $\begin{array}{l}\text { The provision of additional space shall be } \\
\text { considered for temporary shielding or for additional } \\
\text { shielding in the event radiation levels are higher } \\
\text { than anticipated. }\end{array}$ & $\mathrm{C}$ & $\begin{array}{l}\text { The shielding design for the CSB is based on very conservative } \\
\text { assumptions. If additional shielding were to be needed the facility } \\
\text { design can easily accommodate it. }\end{array}$ \\
\hline $0110-99.0 .4$ & 61. & $\begin{array}{l}\text { Storage facilities shall be physically separated from } \\
\text { process operations, areas for the storage of non- } \\
\text { nuclear materials or equipment, and functions not } \\
\text { directly required for storage operations. }\end{array}$ & $\mathrm{C}$ & $\begin{array}{l}\text { The CSB vault provides a physical separation of the stored SNF } \\
\text { from the sampling/weld station area by virtue of the below deck } \\
\text { storage configuration. (Ref: HNF-3553, Figure A2-6). }\end{array}$ \\
\hline
\end{tabular}




\section{Canister Storage Building Compliance Assessment \\ DOE Order 6430.1A, General Design Criteria}

HNF-4742, Rev. 0

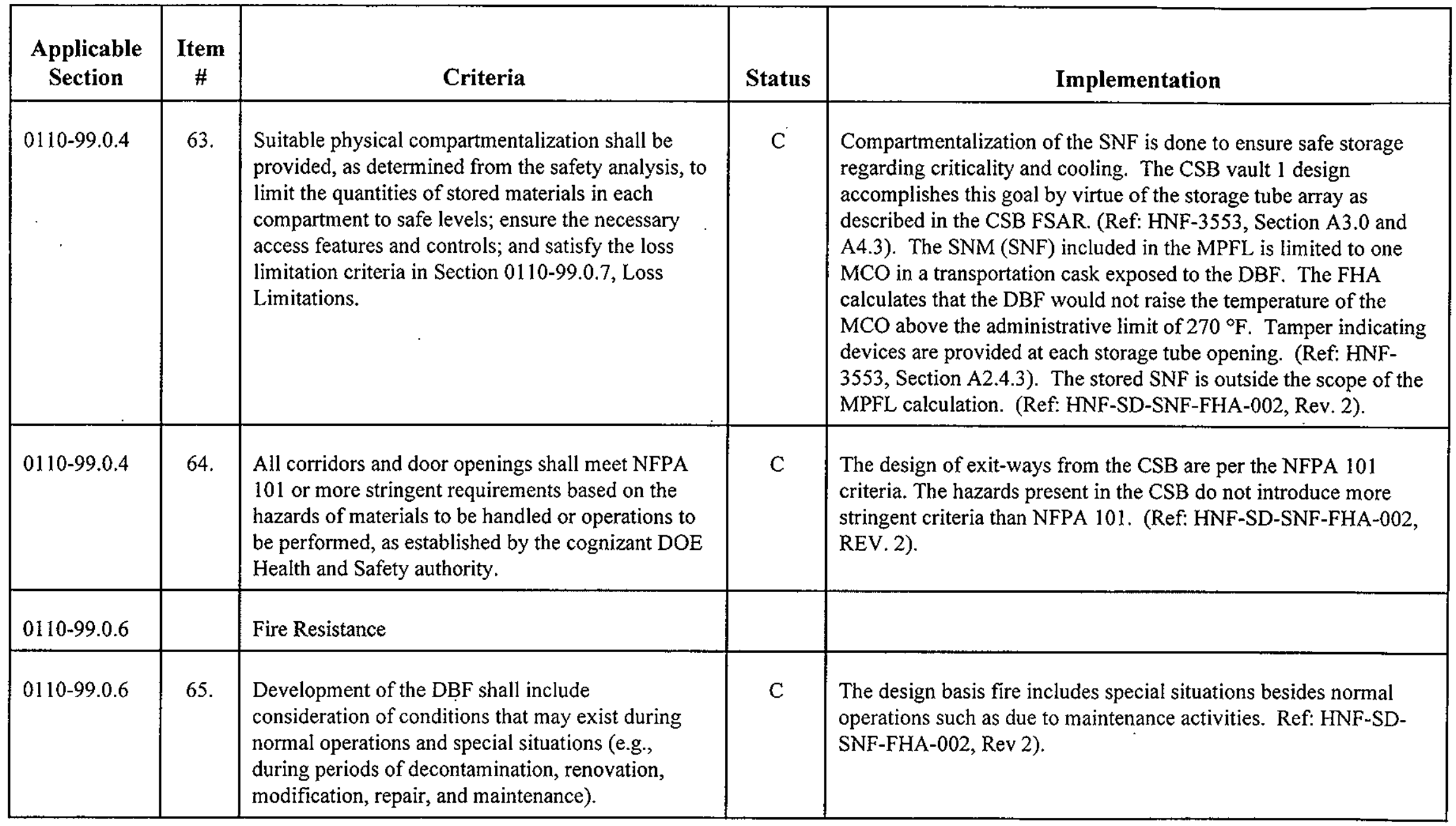




\section{Canister Storage Building Compliance Assessment DOE Order 6430.1A, General Design Criteria}

HNF-4742, Rev. 0

\begin{tabular}{|c|c|c|c|c|}
\hline $\begin{array}{c}\text { Applicable } \\
\text { Section }\end{array}$ & $\begin{array}{c}\text { Item } \\
\#\end{array}$ & Criteria & Status & Implementation \\
\hline $0110-99.0 .6$ & 67. & $\begin{array}{l}\text { In no event shall the fire resistance rating [of the } \\
\text { structural shell] be less than two-hours under } \\
\text { conditions of failure of any fire suppression system } \\
\text { not designed as a safety class item. }\end{array}$ & C & $\begin{array}{l}\text { The operating area shelter is separated from the sprinkled support } \\
\text { building by a 2-hour rated partition wall. (Ref: HNF-3553, Section } \\
\text { A2.7.1). }\end{array}$ \\
\hline $0110-99.0 .7$ & & Loss Limitations & & \\
\hline
\end{tabular}




\section{Canister Storage Building Compliance Assessment \\ DOE Order 6430.1A, General Design Criteria}

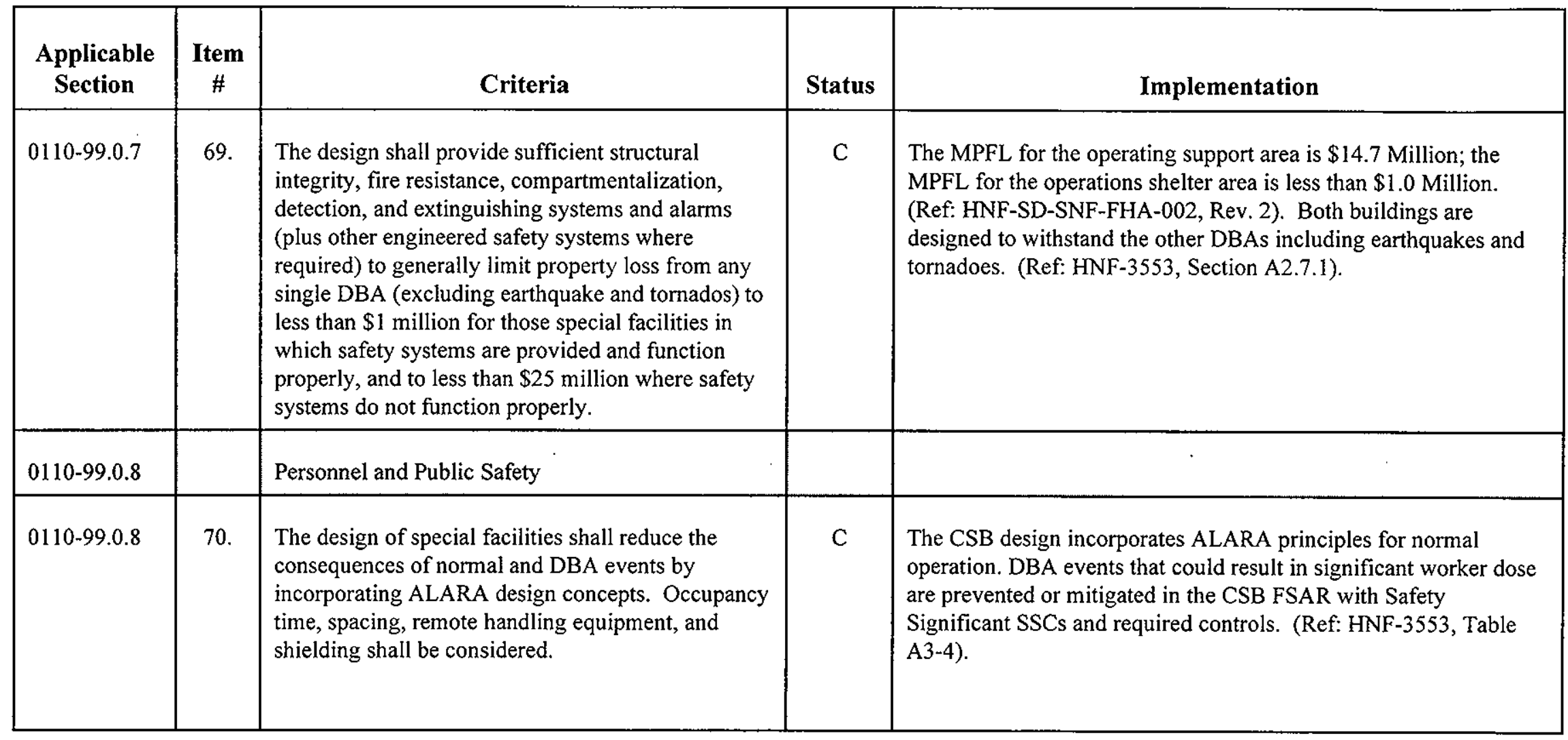




\section{Canister Storage Building Compliance Assessment \\ DOE Order 6430.1A, General Design Criteria}

HNF-4742, Rev. 0

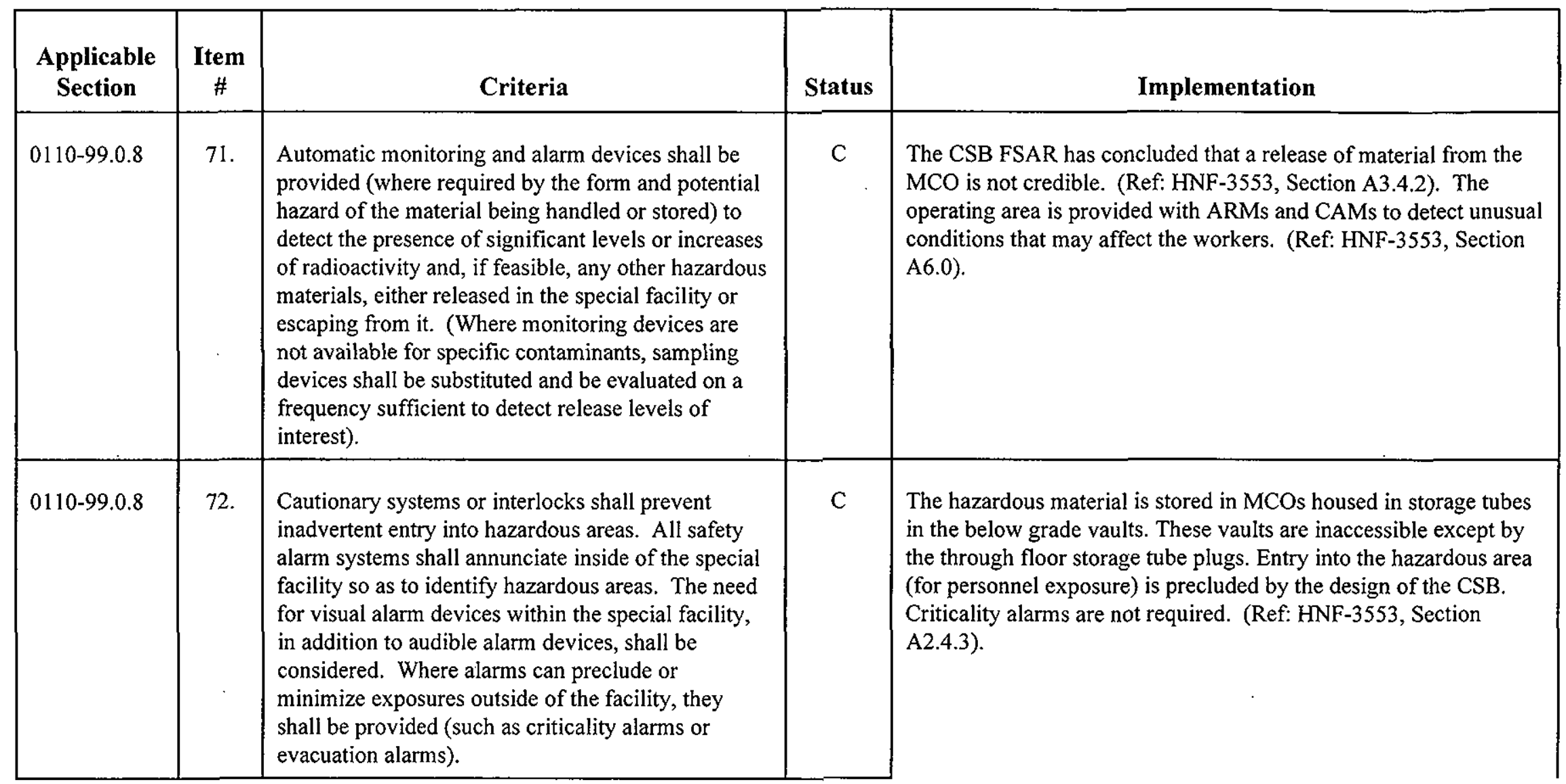




\section{Canister Storage Building Compliance Assessment \\ DOE Order 6430.1A, General Design Criteria}

HNF-4742, Rev. 0

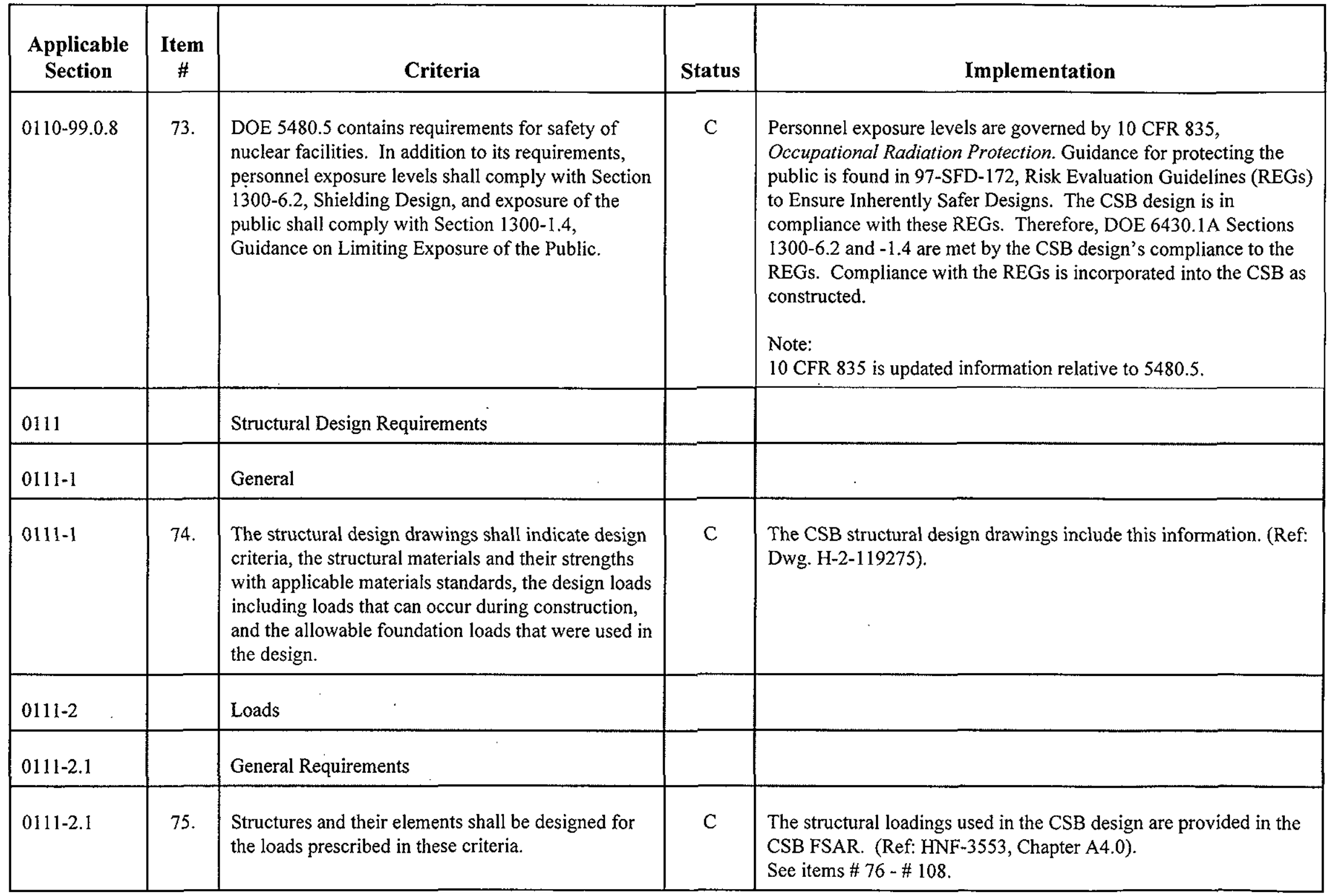




\section{Canister Storage Building Compliance Assessment DOE Order 6430.1A, General Design Criteria}

HNF-4742, Rev. 0

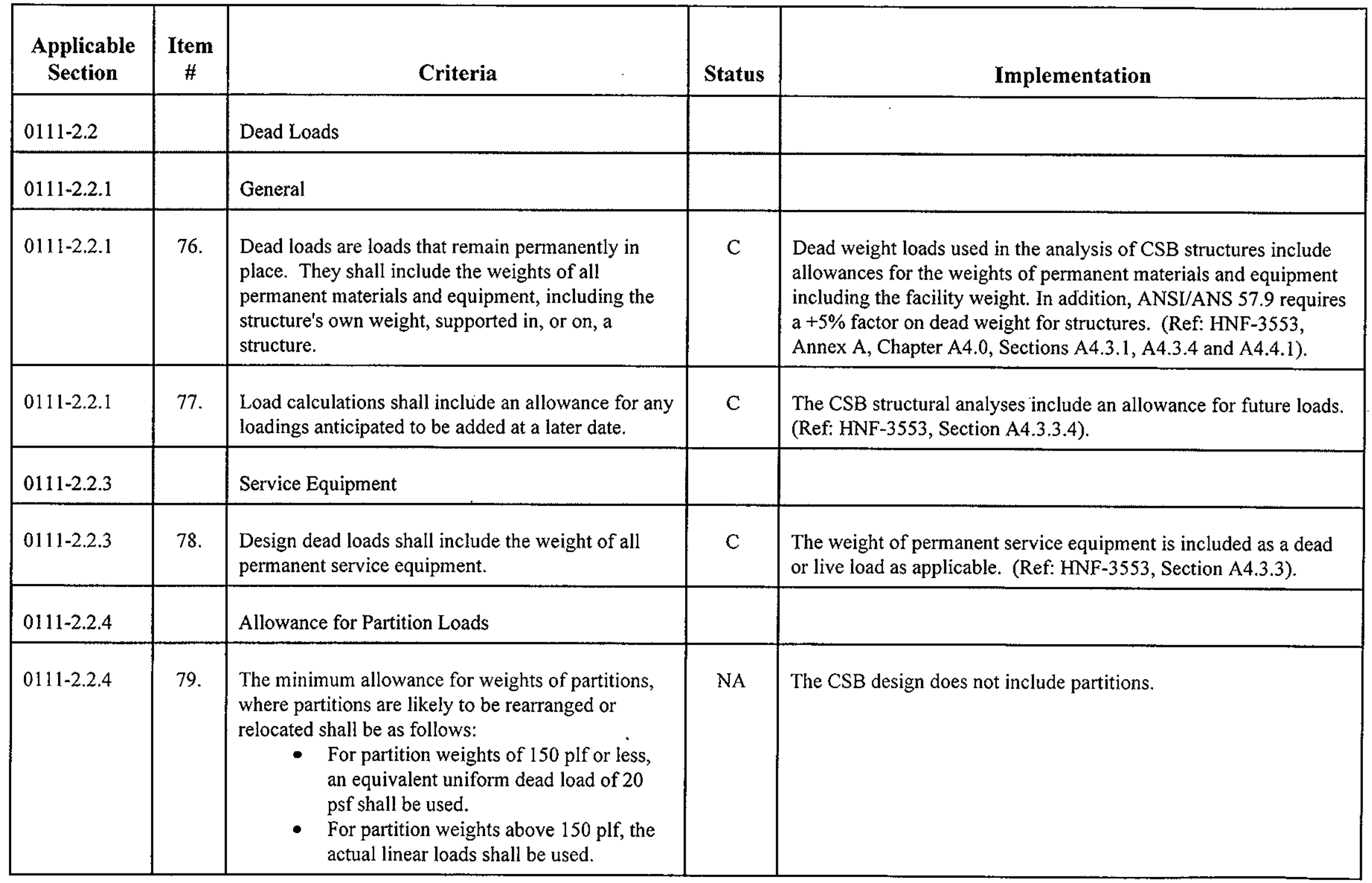




\section{Canister Storage Building Compliance Assessment \\ DOE Order 6430.1A, General Design Criteria}

HNF-4742, Rev. 0

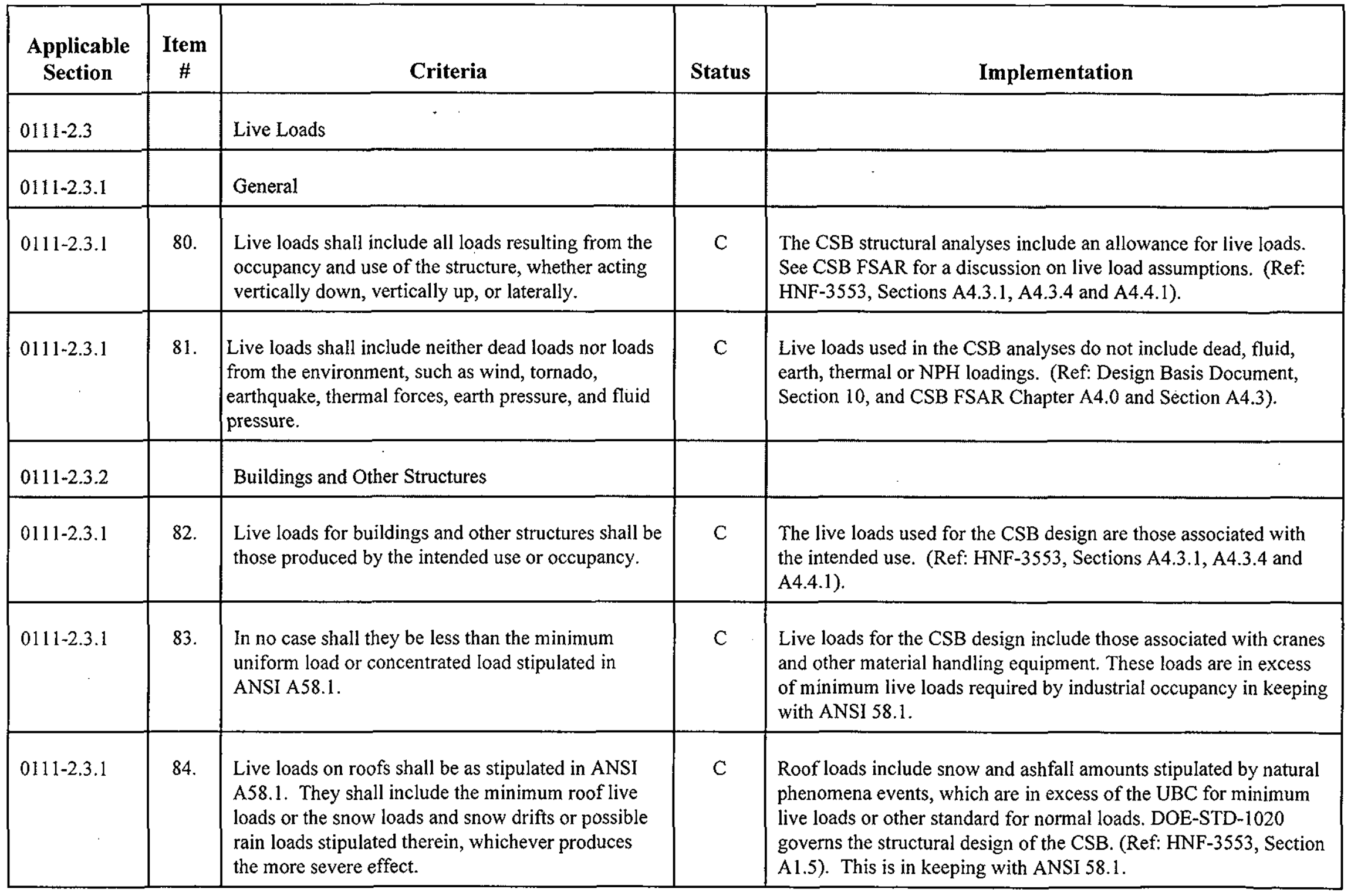




\section{Canister Storage Building Compliance Assessment DOE Order 6430.1A, General Design Criteria}

HNF-4742, Rev. 0

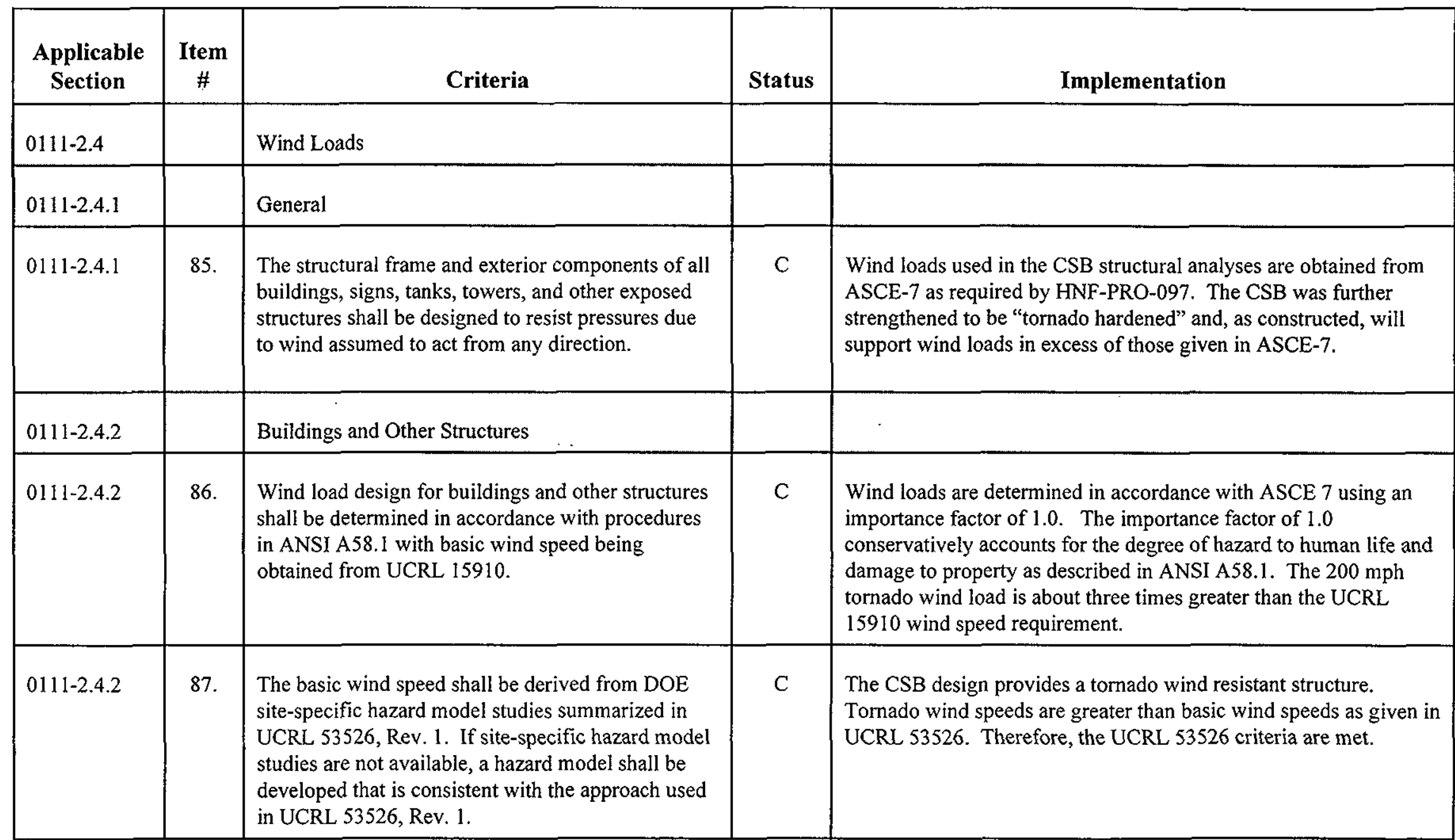




\section{Canister Storage Building Compliance Assessment DOE Order 6430.1A, General Design Criteria}

HNF-4742, Rev. 0

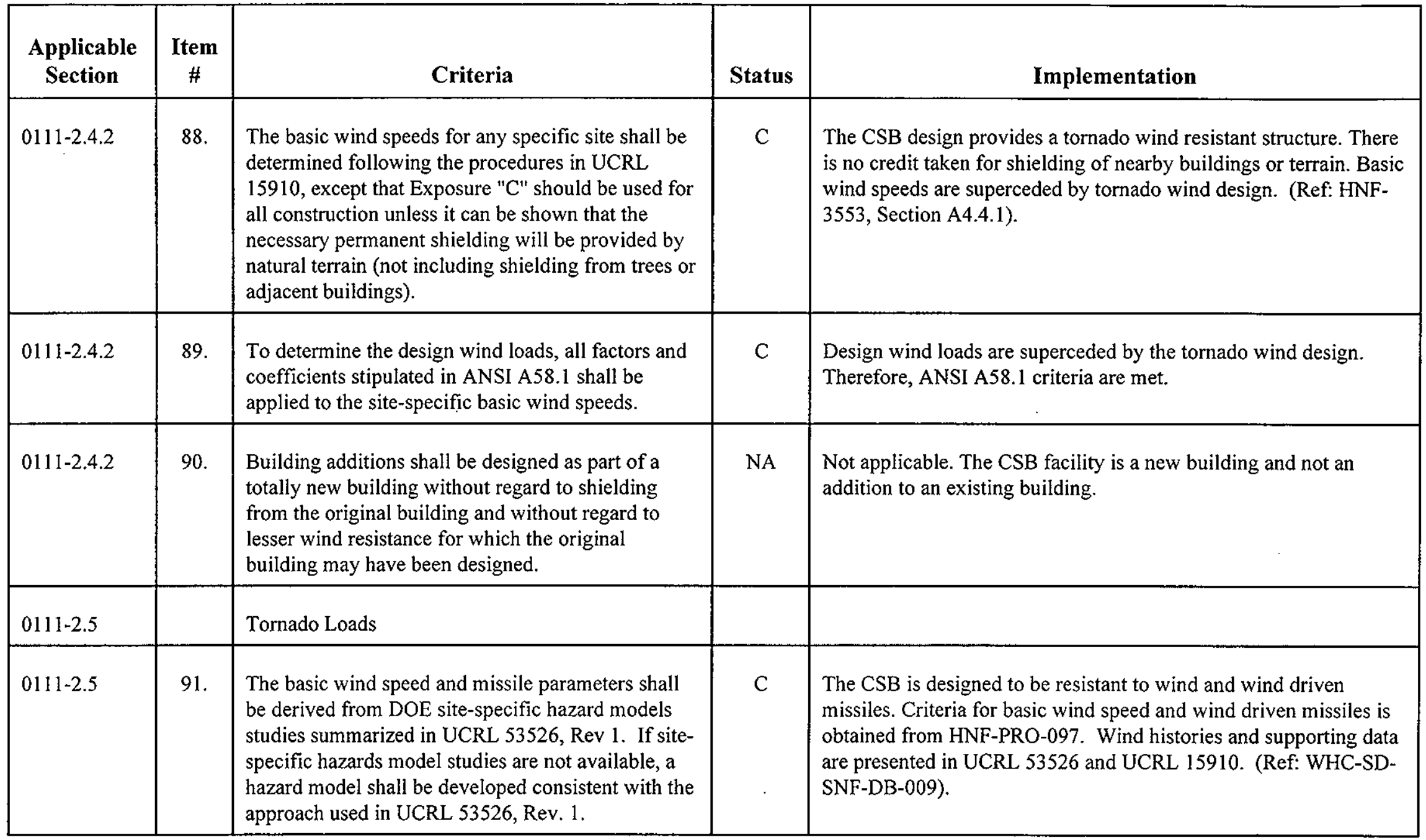




\section{Canister Storage Building Compliance Assessment DOE Order 6430.1A, General Design Criteria}

HNF-4742, Rev. 0

\begin{tabular}{|c|c|c|c|c|}
\hline $0111-2.6$ & & Internal Shock and Blast Loads & & \\
\hline $0111-2.6$ & 93. & $\begin{array}{l}\text { Building structures (excluding explosive facilities) } \\
\text { that house operations that may release energy from } \\
\text { rupture of equipment or explosions, either } \\
\text { inadvertently or purposely (such as testing), shall be } \\
\text { designed to control the resulting internal shock } \\
\text { pressure loads per applicable criteria. }\end{array}$ & NA & $\begin{array}{l}\text { The CSB FSAR has not identified the need for designs to control } \\
\text { internal shock pressures. (Ref: HNF-3553, Section A3.4.2). }\end{array}$ \\
\hline $0111-2.7$ & & Earthquake Loads & & \\
\hline $0111-2.7 .1$ & & Buildings and Other Structures & & \\
\hline $0111-2.7 .1$ & 94. & $\begin{array}{l}\text { The basic seismic parameters shall be derived from } \\
\text { DOE site-specific hazard model studies summarized } \\
\text { in UCRL } 53582 \text {. If site-specific hazard model } \\
\text { studies are not available, a hazard model shall be } \\
\text { developed that is consistent with the approach used } \\
\text { in UCRL } 53582 \text {. In applying UCRL } 53582 \text {, specific } \\
\text { guidance on relating frequency of occurrence to } \\
\text { facility hazard levels shall be obtained from UCRL } \\
15910 \text {. }\end{array}$ & $\mathrm{C}$ & $\begin{array}{l}\text { Earthquake loads are derived from amplified ground accelerations } \\
\text { contained in DOE-STD-1020. These probabilistic hazard models of } \\
\text { UCRL-53582 are the basis of the recommended site hazard curves } \\
\text { in DOE-STD-1020. (Ref: HNF-SD-SNF-DB-004). }\end{array}$ \\
\hline
\end{tabular}




\section{Canister Storage Building Compliance Assessment DOE Order 6430.1A, General Design Criteria}

HNF-4742, Rev. 0

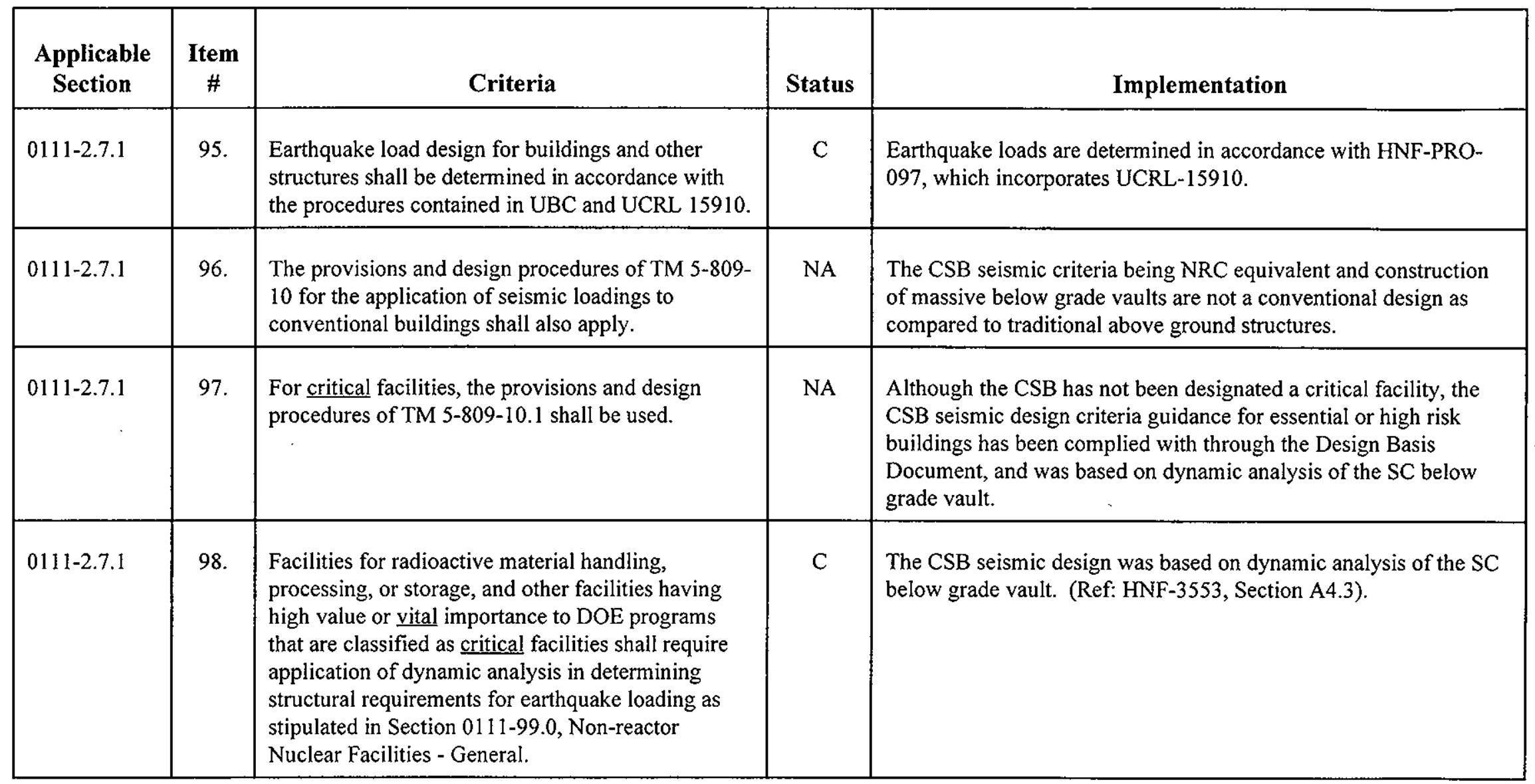




\section{Canister Storage Building Compliance Assessment \\ DOE Order 6430.1A, General Design Criteria}

HNF-4742, Rev. 0

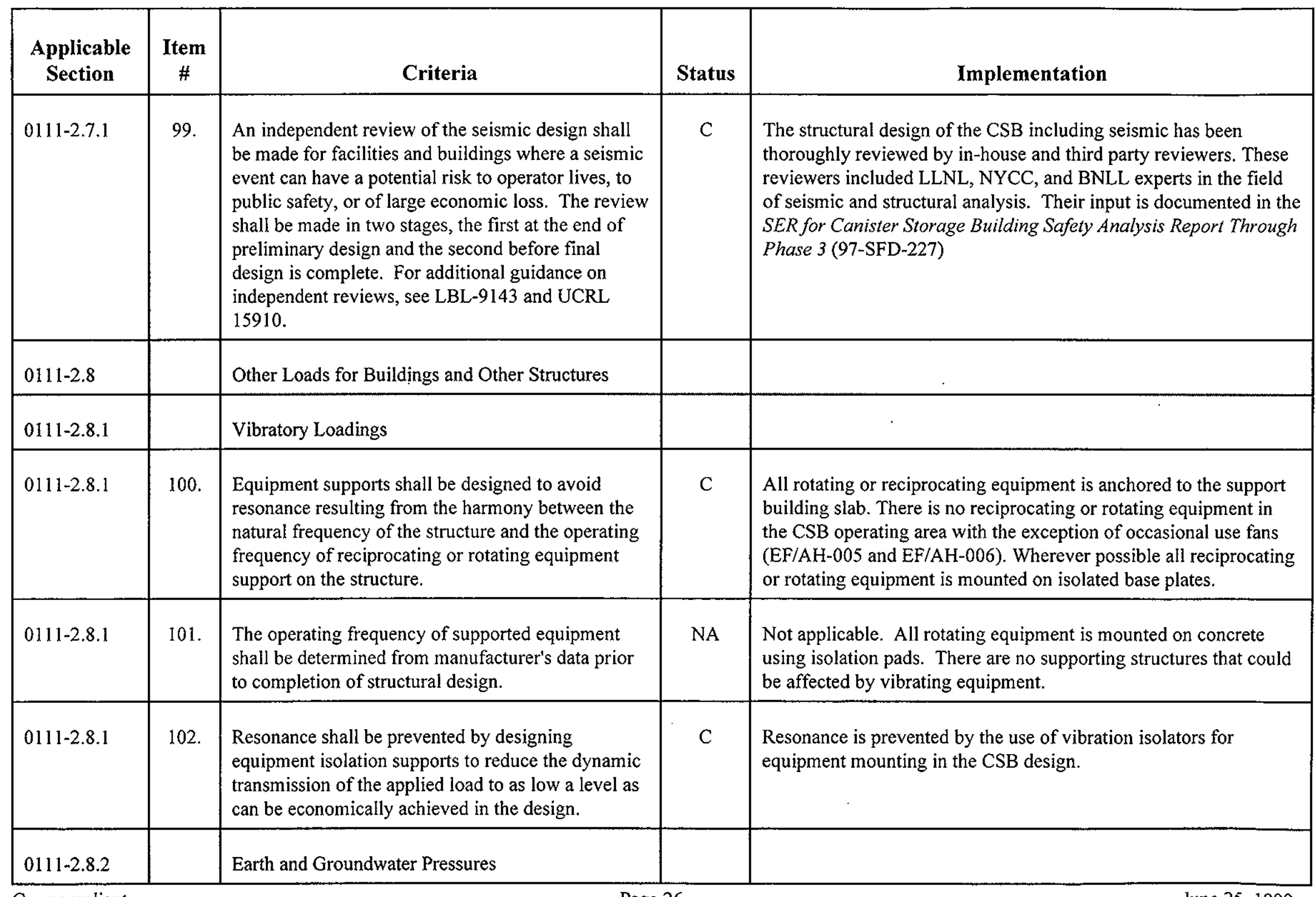




\section{Canister Storage Building Compliance Assessment \\ DOE Order 6430.1A, General Design Criteria}

HNF-4742, Rev. 0

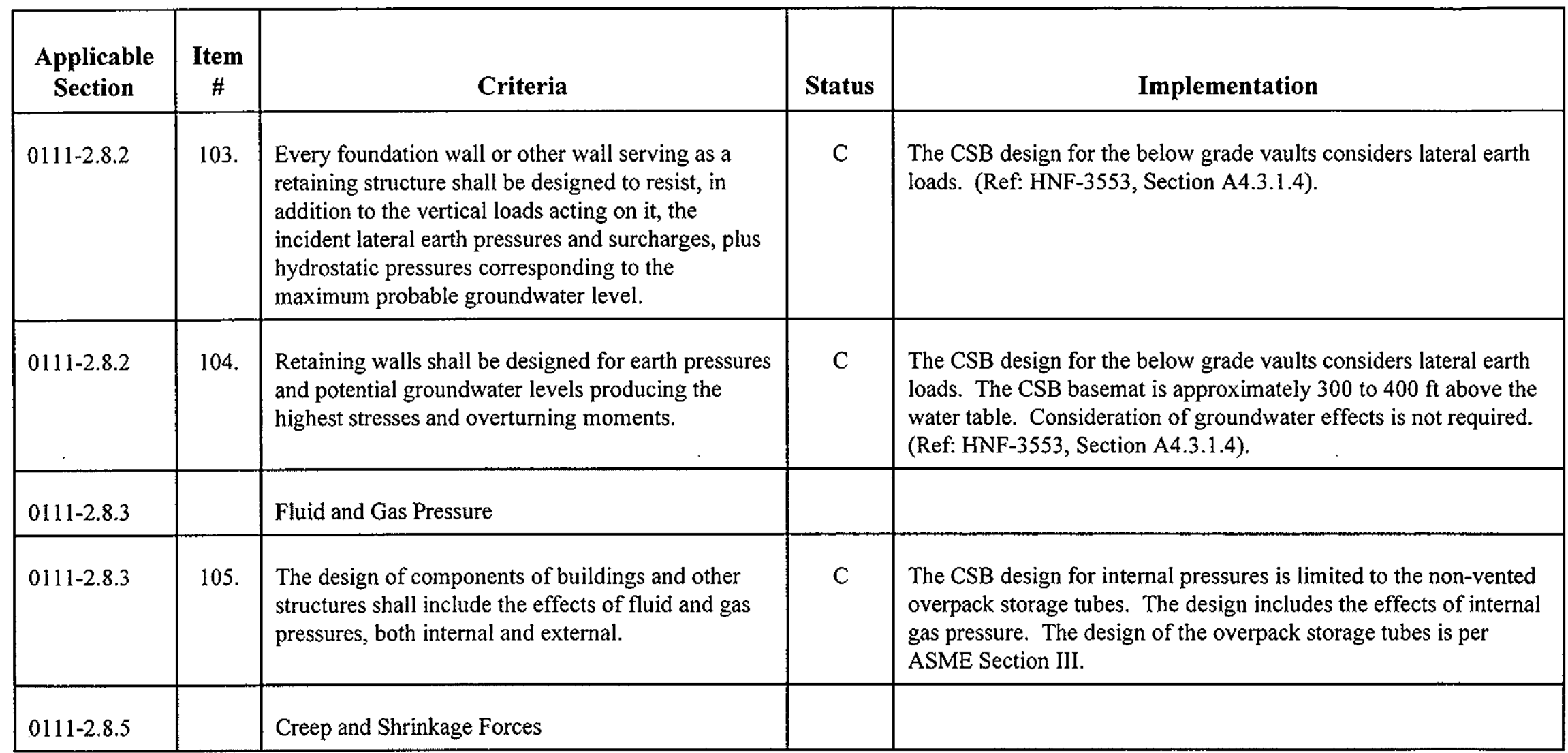




\section{Canister Storage Building Compliance Assessment DOE Order 6430.1A, General Design Criteria}

HNF-4742, Rev. 0

\begin{tabular}{|c|c|c|c|c|}
\hline $0111-2.10$ & & $\begin{array}{l}\text { Combination of Loads and Design Requirements for } \\
\text { Buildings and Other Structures }\end{array}$ & & \\
\hline $0111-3$ & & $\begin{array}{l}\text { Structural Systems for Buildings and Other } \\
\text { Structures }\end{array}$ & & \\
\hline $0111-3.2$ & & Floors & & \\
\hline $0111-3.2$ & 108. & $\begin{array}{l}\text { Where the first floor uses concrete-slab-on-grade } \\
\text { construction, the slab shall be placed on a free- } \\
\text { draining aggregate base overlying a compacted } \\
\text { subgrade. }\end{array}$ & C & $\begin{array}{l}\text { The CSB at-grade reinforced concrete construction is placed on an } \\
\text { aggregate base overlying a compacted subgrade. (Ref: Dwg. H-2- } \\
\text { 119324). }\end{array}$ \\
\hline
\end{tabular}




\section{Canister Storage Building Compliance Assessment \\ DOE Order 6430.1A, General Design Criteria}

HNF-4742, Rev. 0

\begin{tabular}{|c|c|c|c|c|}
\hline $\begin{array}{l}\text { Applicable } \\
\text { Section }\end{array}$ & $\begin{array}{c}\text { Item } \\
\#\end{array}$ & Criteria & Status & Implementation \\
\hline $0111-3.2$ & 110. & $\begin{array}{l}\text { Excessive loads or equipment subject to vibration } \\
\text { shall be supported by separate pads isolated from } \\
\text { the rest of the floor slab with flexible joints. }\end{array}$ & $\mathrm{C}$ & $\begin{array}{l}\text { The CSB equipment foundations in the support building are } \\
\text { separated from the base slab by flexible expansion joints. } \\
\text { Expansion joints are also present between slab and column bases. }\end{array}$ \\
\hline $0111-3.3$ & & Control Joints & & \\
\hline $0111-3.3$ & 111. & $\begin{array}{l}\text { Control joints shall be designed and placed in such a } \\
\text { manner as to avoid structural distress and } \\
\text { uncontrolled cracking from thermal expansion and } \\
\text { contraction, concrete shrinkage, and movements due } \\
\text { to wind and earthquake forces. }\end{array}$ & $\mathrm{C}$ & $\begin{array}{l}\text { Control joints, that have as their primary purpose the prevention of } \\
\text { structural distress and uncontrolled cracking, are appropriately } \\
\text { designed and placed in the CSB construction. }\end{array}$ \\
\hline $0111-3.4 .1$ & & General Requirements & & \\
\hline $0111-3.4 .1$ & 112. & $\begin{array}{l}\text { The provisions of the UBC shall be the minimum } \\
\text { requirements for foundations design. The potential } \\
\text { adverse effects of frost heave and movements due to } \\
\text { expansive soils shall also be considered in the } \\
\text { design. }\end{array}$ & $\mathrm{C}$ & $\begin{array}{l}\text { The design of equipment foundations in the CSB exceed the } \\
\text { minimum required per the UBC. The design takes into account } \\
\text { frost heaving and expansive soil effects. (Ref: Design Basis } \\
\text { Document, Section 10). }\end{array}$ \\
\hline
\end{tabular}




\section{Canister Storage Building Compliance Assessment \\ DOE Order 6430.1A, General Design Criteria}

HNF-4742, Rev. 0

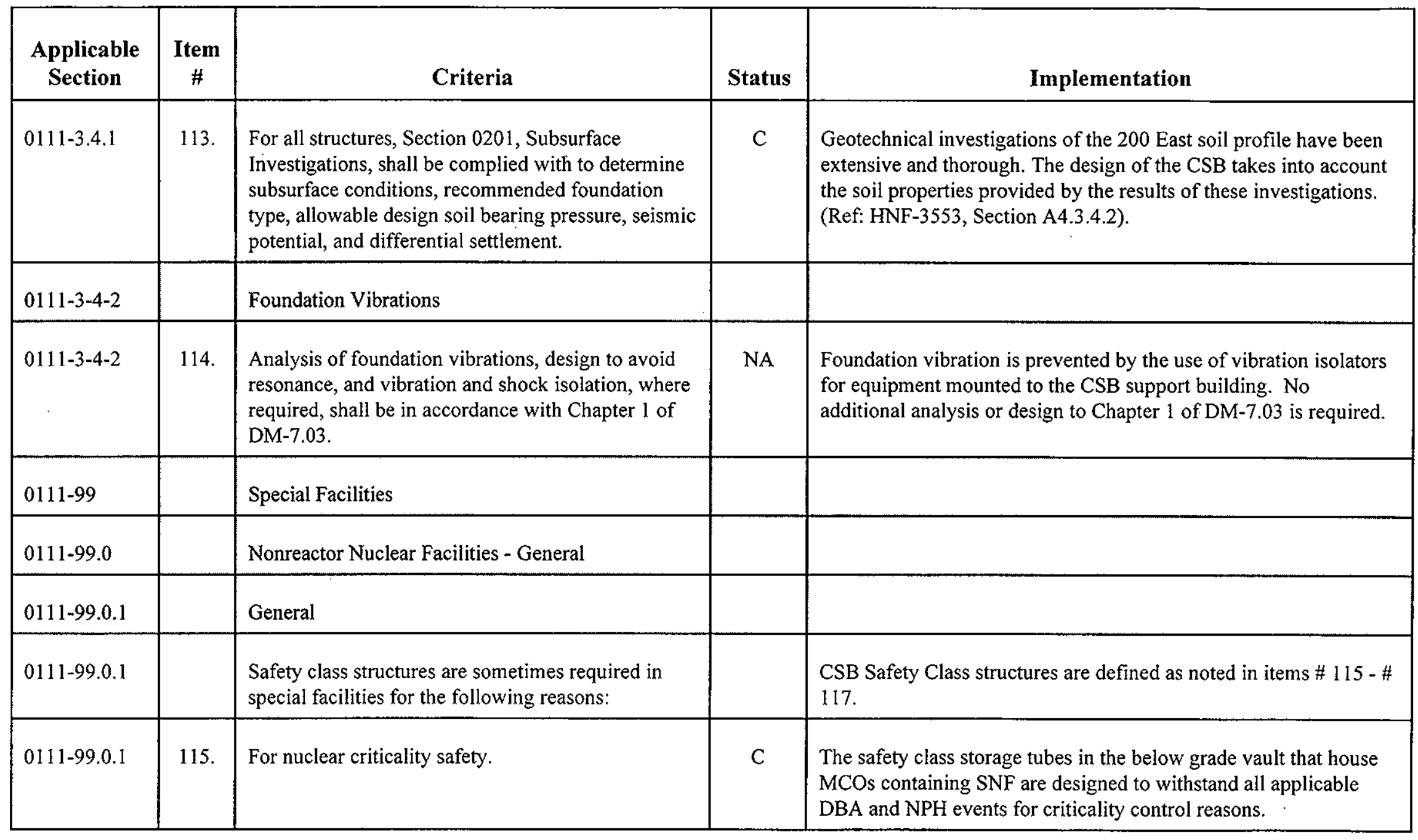




\section{Canister Storage Building Compliance Assessment \\ DOE Order 6430.1A, General Design Criteria}

HNF-4742, Rev. 0

\begin{tabular}{|c|c|c|c|c|}
\hline $0111-99.0 .1$ & 117. & $\begin{array}{l}\text { To achieve and maintain the facility in a safe } \\
\text { shutdown condition. }\end{array}$ & $\mathrm{C}$ & $\begin{array}{l}\text { The CSB design does not require active systems to achieve and } \\
\text { maintain a safe shutdown. }\end{array}$ \\
\hline $0111-99.0 .1$ & 118. & $\begin{array}{l}\text { Special facility structures that need not be designed } \\
\text { to withstand severe natural phenomena or man- } \\
\text { made events shall be designed to the requirements } \\
\text { in Section } 0111-2 \text {, Loads. }\end{array}$ & NA & $\begin{array}{l}\text { The CSB design addresses severe natural phenomena criteria. } \\
\text { (Ref: HNF-3553, Chapter A1.0). }\end{array}$ \\
\hline $0111-99.0 .1$ & 120. & $\begin{array}{l}\text { Safety class structures shall be protected against } \\
\text { dynamic effects, including effects of wind driven } \\
\text { missiles and discharging fluids, that may result from } \\
\text { natural phenomena, accidents at nearby facilities, } \\
\text { including military installations and transportation } \\
\text { facilities, equipment failure, and similar events and } \\
\text { conditions inside and outside the facility. }\end{array}$ & $\mathrm{C}$ & $\begin{array}{l}\text { The CSB FSAR has not identified credible events that result in } \\
\text { missiles impacting safety class structures. The CSB operating } \\
\text { shelter is resistant to wind driven missiles. (Ref: HNF-3553, } \\
\text { Section A4.4.1). }\end{array}$ \\
\hline
\end{tabular}




\section{Canister Storage Building Compliance Assessment \\ DOE Order 6430.1A, General Design Criteria}

HNF-4742, Rev. 0

\begin{tabular}{|c|c|c|c|c|}
\hline 0111-99.0.1 & 122. & $\begin{array}{l}\text { Where floor-mounted special facilities equipment } \\
\text { will have a commonality of use, it shall be centrally } \\
\text { located with respect to special facilities operations. }\end{array}$ & $\mathrm{C}$ & $\begin{array}{l}\text { The CSB design uses dedicated equipment for the individual } \\
\text { functions. Where equipment is used at separate locations within the } \\
\text { facility the equipment is designed to be mobile. }\end{array}$ \\
\hline $0111-99.0 .1$ & 123. & $\begin{array}{l}\text { The design of structures, including their supports, } \\
\text { that are confinement system barriers shall ensure } \\
\text { satisfaction of the functional requirements for the } \\
\text { specific confinement system they are part of. }\end{array}$ & $\mathrm{C}$ & $\begin{array}{l}\text { Design requirements of confinement barriers are demonstrated by } \\
\text { functional test relative to its next confinement barrier or the } \\
\text { environment as applicable. }\end{array}$ \\
\hline $0111-99.0 .1$ & 125. & $\begin{array}{l}\text { In no case shall the total combustible loading } \\
\text { located in a fire area exceed the fire resistance rating } \\
\text { of the area enclosure. This shall be documented in a } \\
\text { fire risk analysis. }\end{array}$ & C & $\begin{array}{l}\text { The CSB final Fire Hazards Analysis documents the permissible } \\
\text { combustible loadings in the various areas of the CSB. These } \\
\text { combustible loading limits need to be complied with during facility } \\
\text { operation. (Ref: HNF-SD-SNF-FHA-002 Rev. 2). }\end{array}$ \\
\hline
\end{tabular}




\section{Canister Storage Building Compliance Assessment \\ DOE Order 6430.1A, General Design Criteria}

HNF-4742, Rev. 0

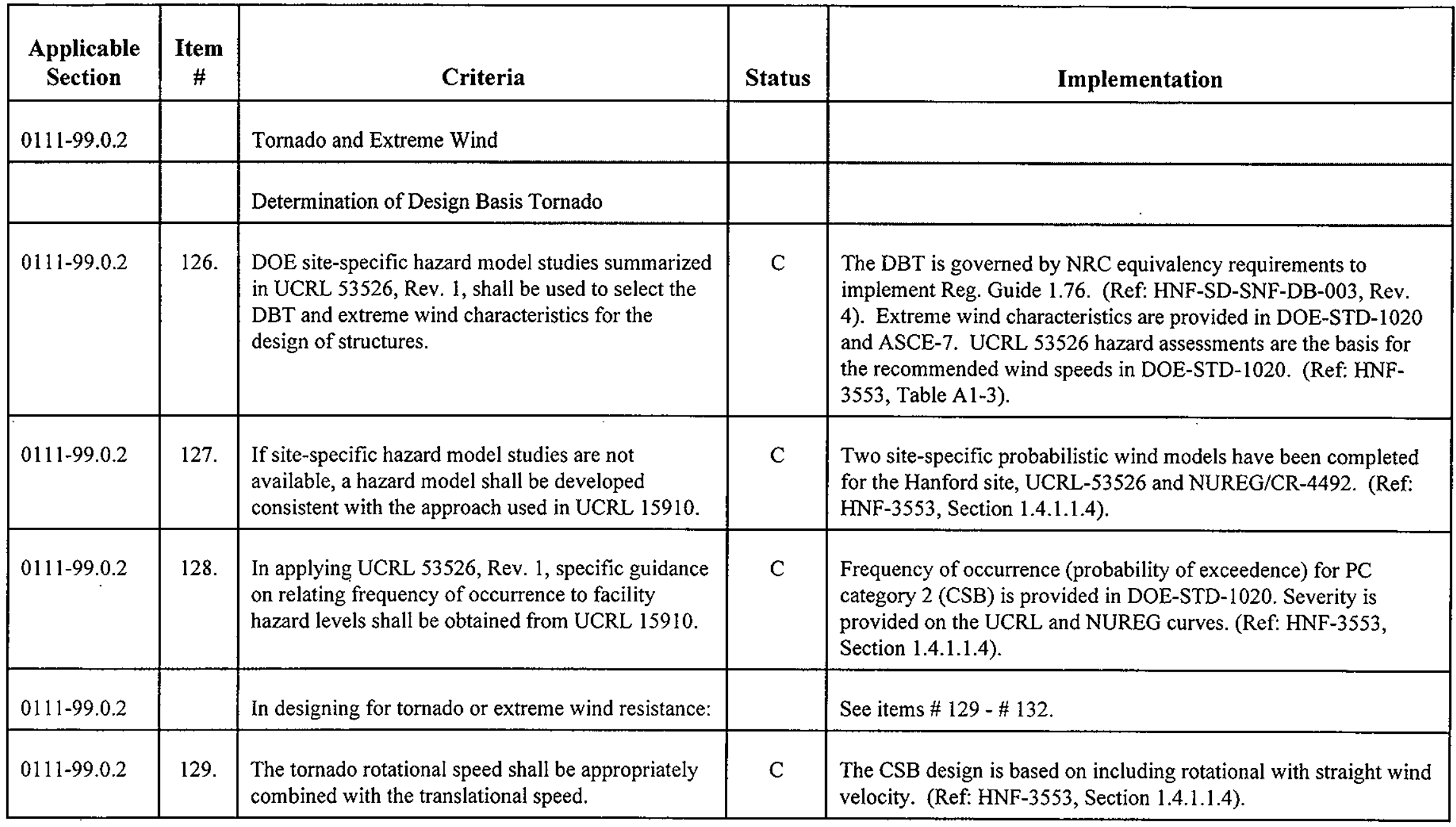




\section{Canister Storage Building Compliance Assessment \\ DOE Order 6430.1A, General Design Criteria}

HNF-4742, Rev. 0

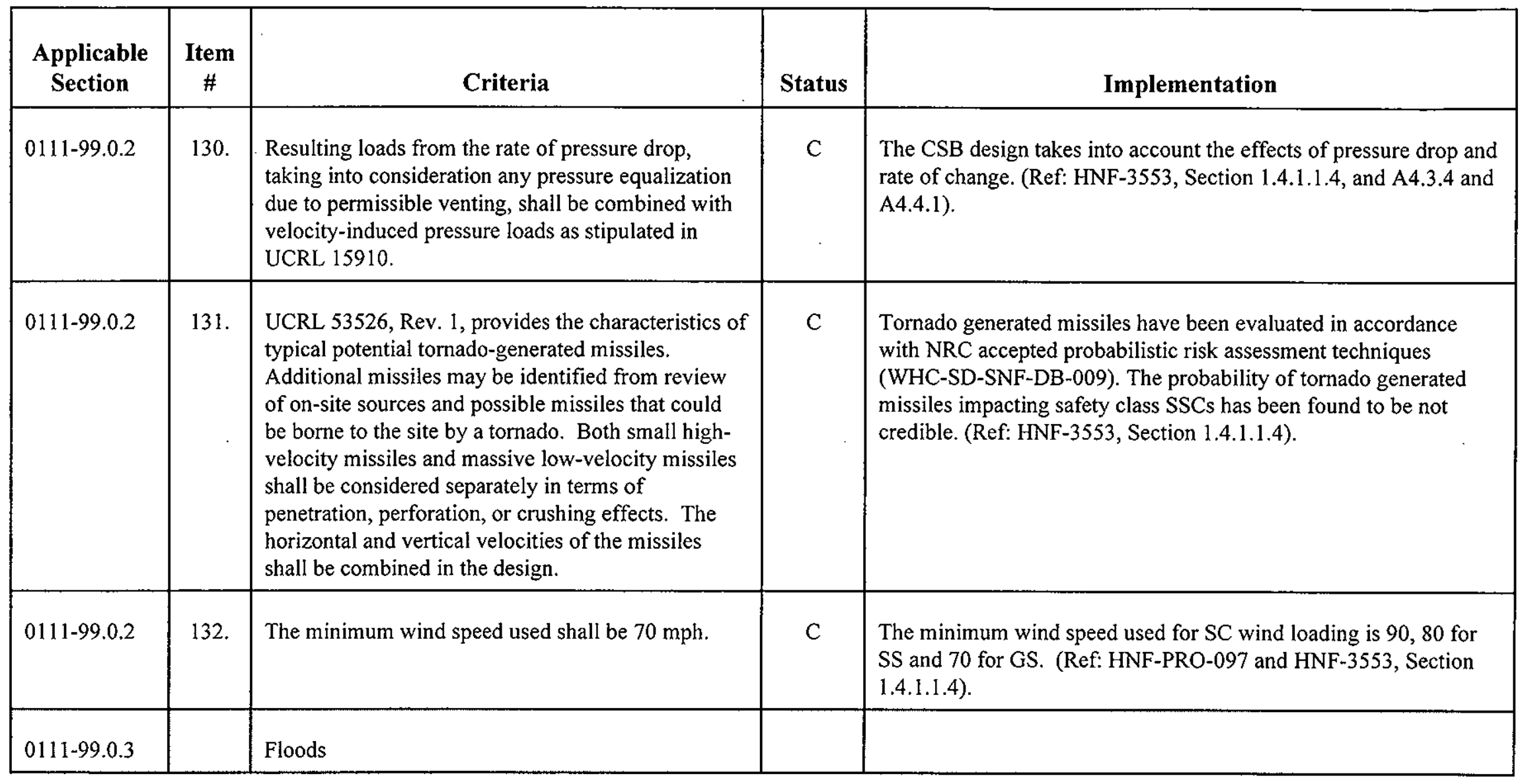




\section{Canister Storage Building Compliance Assessment \\ DOE Order 6430.1A, General Design Criteria}

HNF-4742, Rev. 0

\begin{tabular}{|c|c|c|c|c|}
\hline $\begin{array}{l}\text { Applicable } \\
\text { Section }\end{array}$ & $\begin{array}{c}\text { Item } \\
\#\end{array}$ & Criteria & Status & Implementation \\
\hline $0111-99.0 .4$ & & Earthquakes & & \\
\hline $0111-99.0 .4$ & 135. & $\begin{array}{l}\text { The systems, components, and structures that shall } \\
\text { be designed to meet these special facility criteria } \\
\text { shall be identified through a written evaluation (see } \\
\text { Section } 0111-99.0 .1 \text {, General). }\end{array}$ & $\mathrm{C}$ & $\begin{array}{l}\text { Safety class systems, structures, and components required to } \\
\text { withstand severe natural phenomena are identified in the CSB } \\
\text { FSAR. (Ref: HNF-3553, Section A4.3). }\end{array}$ \\
\hline $0111-99.0 .4$ & 136. & $\begin{array}{l}\text { Such systems, components, and structures shall be } \\
\text { designed to provide their passive or active functions } \\
\text { as required by the SAR in accord with their } \\
\text { designated safety classes. }\end{array}$ & $\mathrm{C}$ & $\begin{array}{l}\text { These SSCs provide their identified active or passive safety class } \\
\text { function as determined by the CSB FSAR accident analysis. (Ref: } \\
\text { HNF-3553, Section A4.3). }\end{array}$ \\
\hline
\end{tabular}




\section{Canister Storage Building Compliance Assessment DOE Order 6430.1A, General Design Criteria}

HNF-4742, Rev. 0

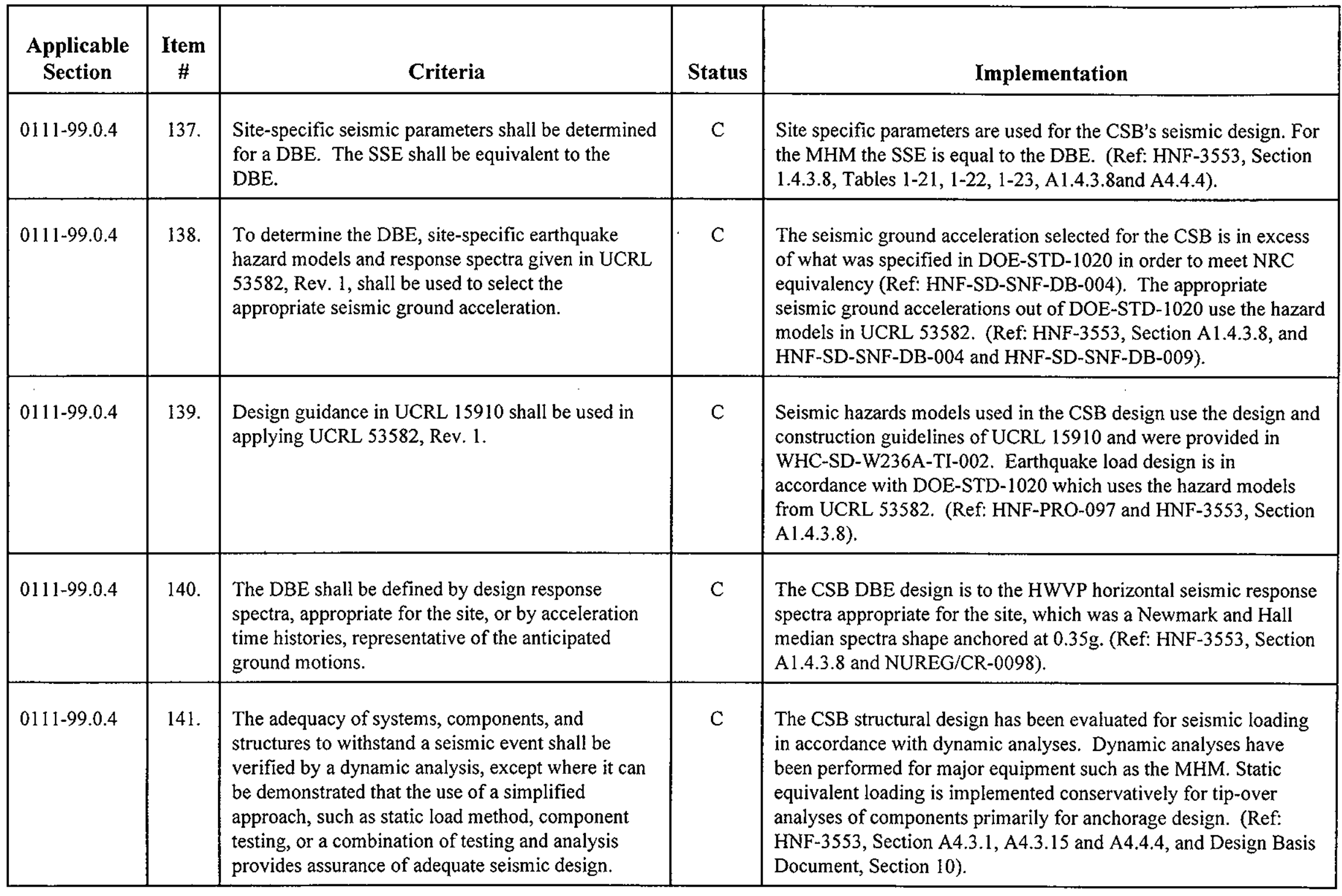




\section{Canister Storage Building Compliance Assessment \\ DOE Order 6430.1A, General Design Criteria}

HNF-4742, Rev. 0

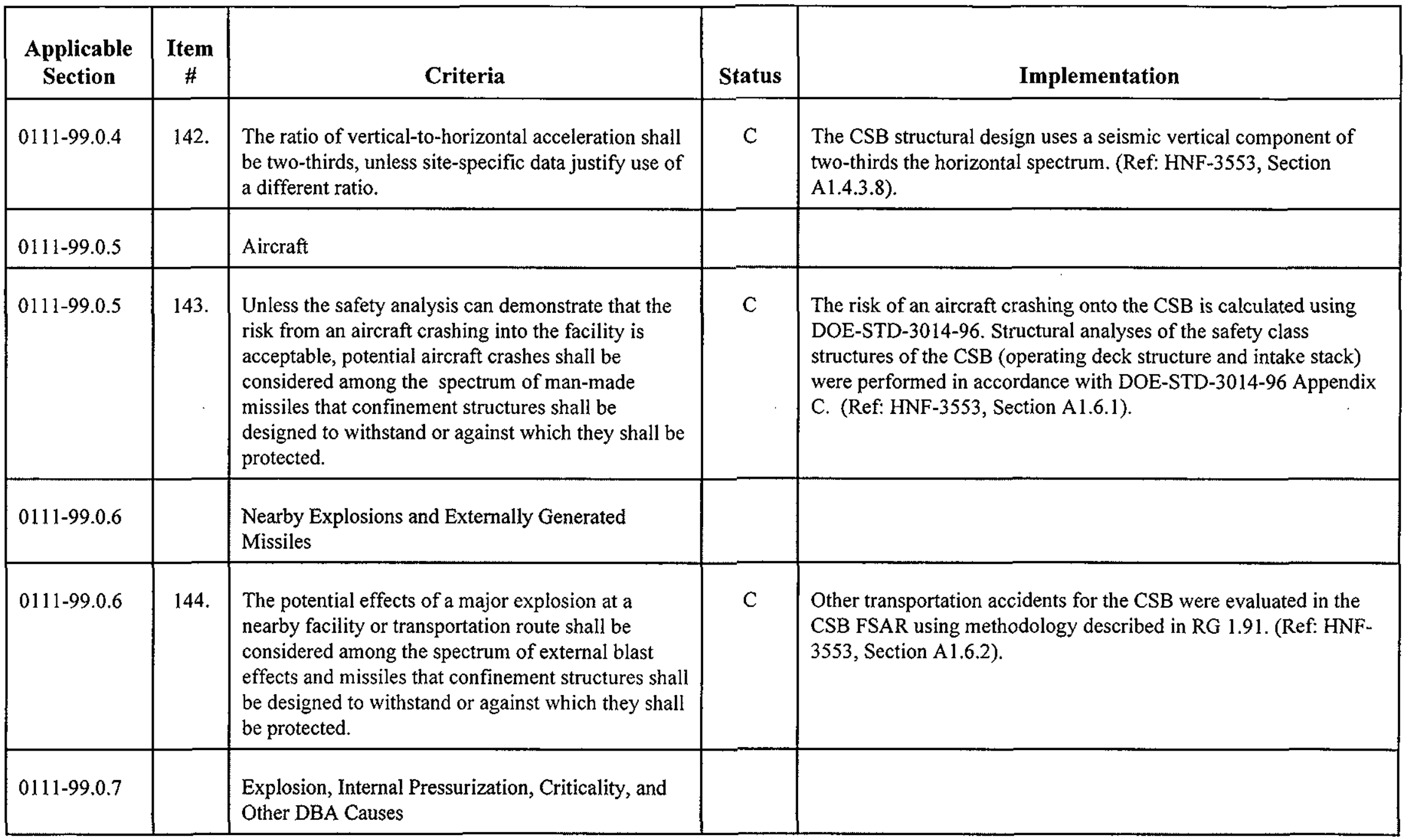




\section{Canister Storage Building Compliance Assessment \\ DOE Order 6430.1A, General Design Criteria}

HNF-4742, Rev. 0

\begin{tabular}{|c|c|c|c|c|}
\hline $\begin{array}{l}\text { Applicable } \\
\text { Section }\end{array}$ & $\begin{array}{c}\text { Item } \\
\#\end{array}$ & Criteria & Status & Implementation \\
\hline $0111-99.0 .8$ & & Load Combinations & & \\
\hline $0111-99.0 .8$ & 146. & $\begin{array}{l}\text { Safety class structures and structural members shall } \\
\text { be designed to resist the appropriate load } \\
\text { combinations provided in UCRL } 15910 \text {. }\end{array}$ & $\mathrm{C}$ & $\begin{array}{l}\text { Load combinations for the CSB safety class structures include NPH } \\
\text { event loads in combination with normal operating loads as } \\
\text { provided in UCRL 15910. These load combinations are in } \\
\text { accordance with DOE-STD-1020. (Ref: HNF-PRO-097 and HNF- } \\
3553 \text {, Table A4-3). }\end{array}$ \\
\hline $0111-99.0 .8$ & & Concrete Structures & & \\
\hline $0111-99.0 .8$ & 147. & $\begin{array}{l}\text { Concrete structures and structural members for } \\
\text { safety class concrete structures shall meet the design } \\
\text { and construction requirements of ACI } 349 \text { for new } \\
\text { construction or original (or equivalent) codes for } \\
\text { existing construction providing the margin of safety } \\
\text { of the overall facility is maintained. }\end{array}$ & $\mathrm{C}$ & $\begin{array}{l}\text { The safety class reinforced concrete structures comprising the CSB } \\
\text { are designed in accordance with load combinations per ACl-349. } \\
\text { (Ref: HNF-3553, Section A4.3.1 and Design Basis Document, } \\
\text { Section 10). }\end{array}$ \\
\hline $0111-99.0 .8$ & & Steel Structures & & \\
\hline
\end{tabular}




\section{Canister Storage Building Compliance Assessment \\ DOE Order 6430.1A, General Design Criteria}

HNF-4742, Rev. 0

\begin{tabular}{|c|c|c|c|c|}
\hline $\begin{array}{l}\text { Applicable } \\
\text { Section }\end{array}$ & $\begin{array}{c}\text { Item } \\
\#\end{array}$ & Criteria & Status & Implementation \\
\hline 0140 & & Quality Assurance & & \\
\hline 0140 & 149. & $\begin{array}{l}\text { A QA program shall be developed and implemented } \\
\text { in compliance with DOE } 5700.6 \mathrm{~b} \text { and using the } \\
\text { elements of DOE } 4700.1 \text { and ANS ANSI/ASME } \\
\text { NQA-1. }\end{array}$ & $\mathrm{C}$ & $\begin{array}{l}\text { Development and implementation of the quality assurance program } \\
\text { is in compliance with 10 CFR } 830.120 \text { and DOE order } 5700.6 \mathrm{C} \text {. } \\
\text { (Ref: HNF-3553, Section 14.3). }\end{array}$ \\
\hline $0200-1$ & & Facility Siting & & \\
\hline $0200 \sim 1.2$ & & Radiological Siting Requirements & & \\
\hline $0200-1.2$ & 150. & $\begin{array}{l}\text { For those facilities in which radioactive materials } \\
\text { are processed, used, or stored, or those facilities that } \\
\text { incorporate radiation-producing machines, the } \\
\text { acceptability of the site shall be evaluated in terms } \\
\text { of potential radiological consequences. }\end{array}$ & $\mathrm{C}$ & $\begin{array}{l}\text { The potential radiological consequences of the storage of spent } \\
\text { nuclear fuel canisters in the CSB is documented in the CSB FSAR. } \\
\text { (Ref: HNF-3553, Section } 1.7 \text { and A1.7). }\end{array}$ \\
\hline
\end{tabular}




\section{Canister Storage Building Compliance Assessment \\ DOE Order 6430.1A, General Design Criteria}

HNF-4742, Rev. 0

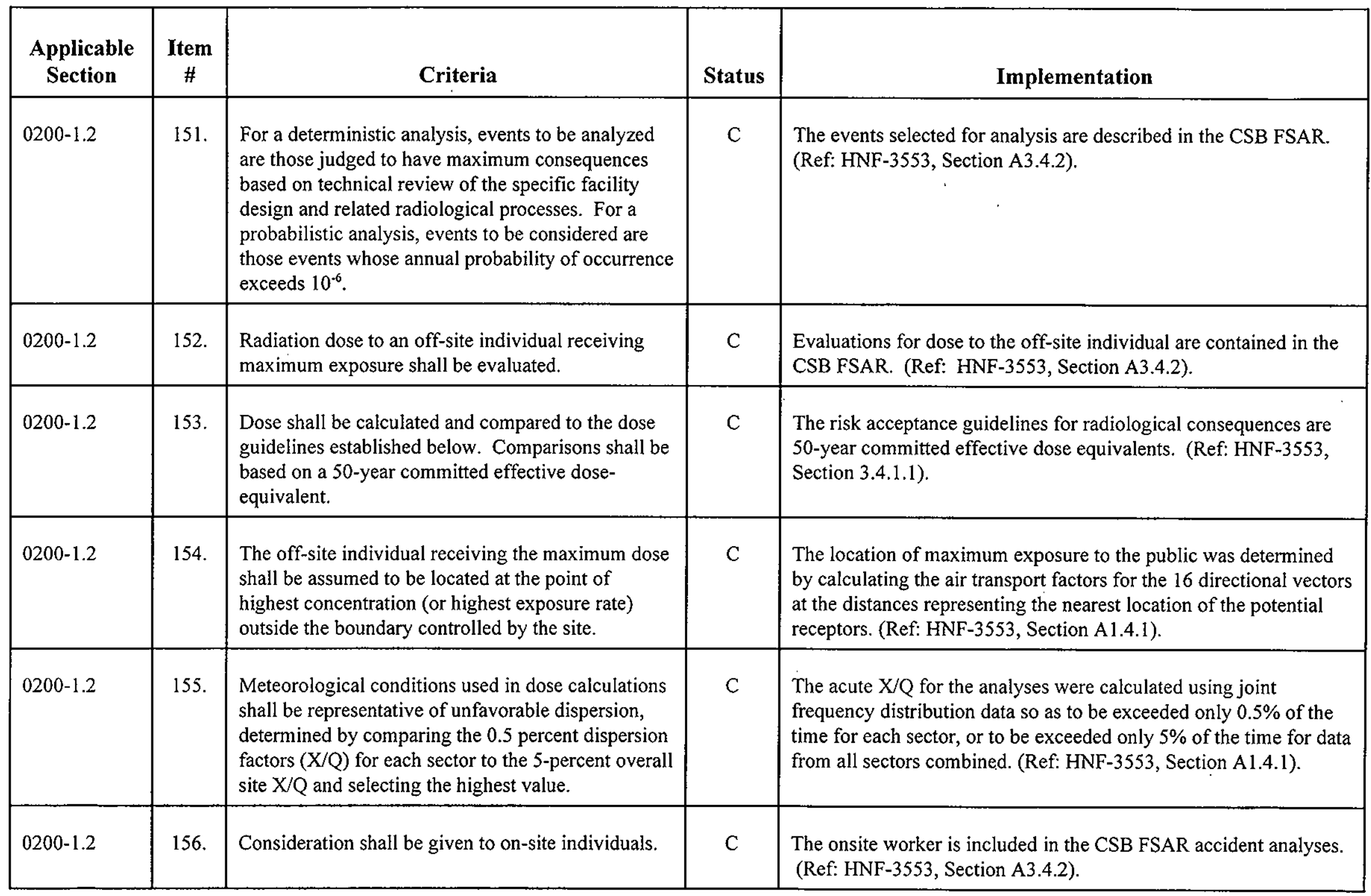




\section{Canister Storage Building Compliance Assessment \\ DOE Order 6430.1A, General Design Criteria}

HNF-4742, Rev. 0

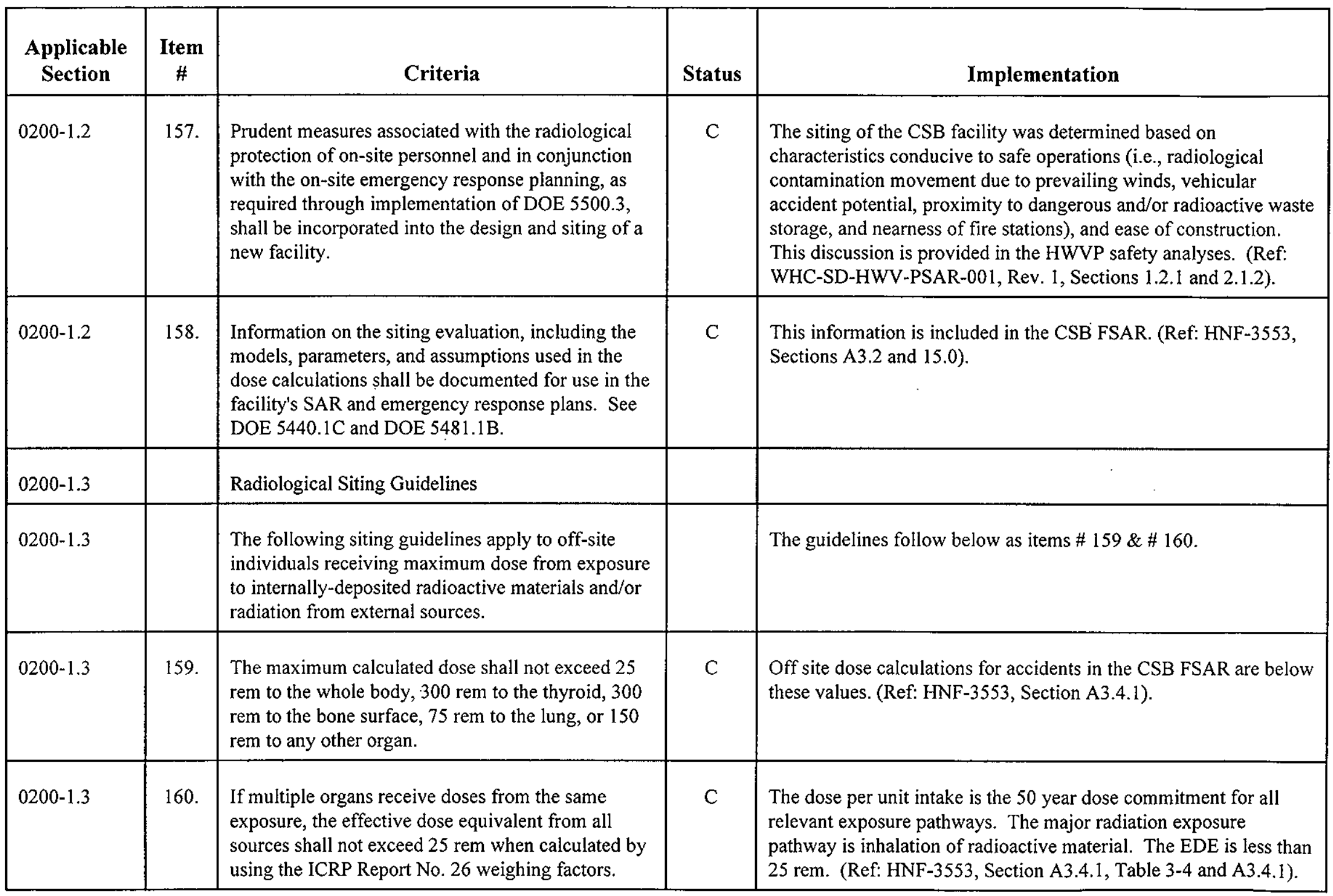




\section{Canister Storage Building Compliance Assessment \\ DOE Order 6430.1A, General Design Criteria}

HNF-4742, Rev. 0

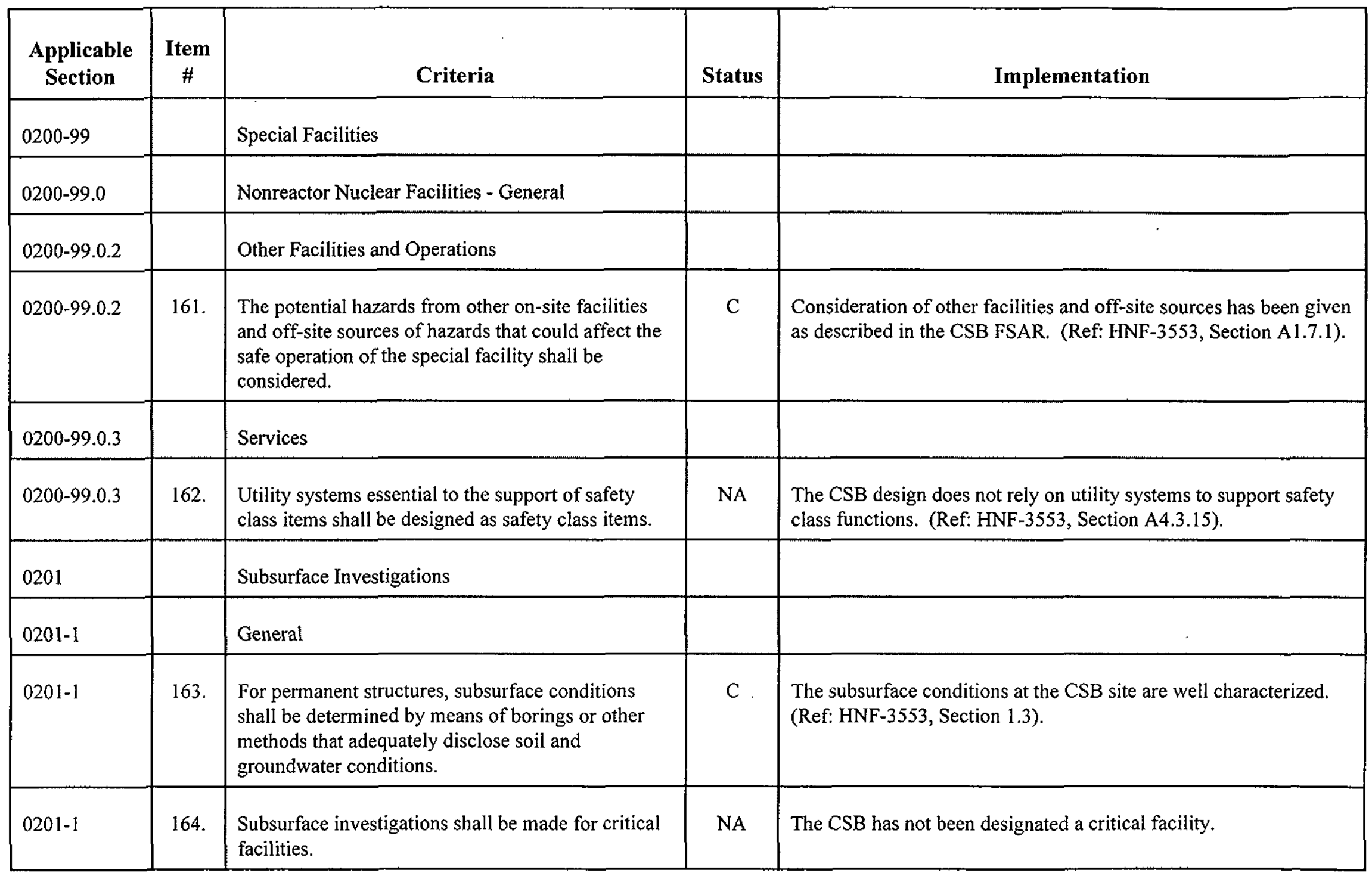




\section{Canister Storage Building Compliance Assessment \\ DOE Order 6430.1A, General Design Criteria}

HNF-4742, Rev. 0

\begin{tabular}{|l|c|l|c|l|}
\hline $\begin{array}{c}\text { Applicable } \\
\text { Section }\end{array}$ & $\begin{array}{c}\text { Item } \\
\text { \# }\end{array}$ & Criteria & Status & \multicolumn{1}{|c|}{ Implementation } \\
\hline $0201-1$ & 165. & $\begin{array}{l}\text { A settlement analysis under differential design loads } \\
\text { shall be performed where differential settlement } \\
\text { may cause structural or architectural damage. }\end{array}$ & C & $\begin{array}{l}\text { The effects of differential settlement between the slab on grade } \\
\text { extensions of the operating deck above the vault and the vault has } \\
\text { been considered in the design of the CSB. Settlement of the } \\
\text { support building slab has also been considered. (Ref: HNF-3553, } \\
\text { Section A4.3.1). }\end{array}$ \\
\hline $0201-4$ & 166. & $\begin{array}{l}\text { The soils engineer shall analyze the information } \\
\text { developed by investigation or otherwise available, } \\
\text { including any aspect of the soil conditions that } \\
\text { might affect design and construction of proposed } \\
\text { structures, and shall consult with the engineer on the } \\
\text { design requirements of the project. }\end{array}$ & $\begin{array}{l}\text { Foundation Engineering Evaluation and } \\
\text { Recommendations }\end{array}$ & $\begin{array}{l}\text { The basis for the CSB construction in the 200 East area of the } \\
\text { Hanford site is described in the HWVP PSAR. The CSB below . } \\
\text { grade basemat and slab on grade construction is based on } \\
\text { recommendations based on investigations of the soil profile strata. } \\
\text { (Refs: WHC-SD-HWV-PSAR-001, Rev 1, Section 3.6.1.9 and the } \\
\text { Dames \& Moore report). }\end{array}$ \\
\hline
\end{tabular}




\section{Canister Storage Building Compliance Assessment \\ DOE Order 6430.1A, General Design Criteria}

HNF-4742, Rev. 0

\begin{tabular}{|c|c|c|c|c|}
\hline $\begin{array}{l}\text { Applicable } \\
\text { Section }\end{array}$ & $\begin{array}{c}\text { Item } \\
\#\end{array}$ & Criteria & Status & Implementation \\
\hline 0235 & & Building Foundations & & \\
\hline $0235-3$ & & Concrete & & \\
\hline
\end{tabular}




\section{Canister Storage Building Compliance Assessment \\ DOE Order 6430.1A, General Design Criteria}

HNF-4742, Rev. 0

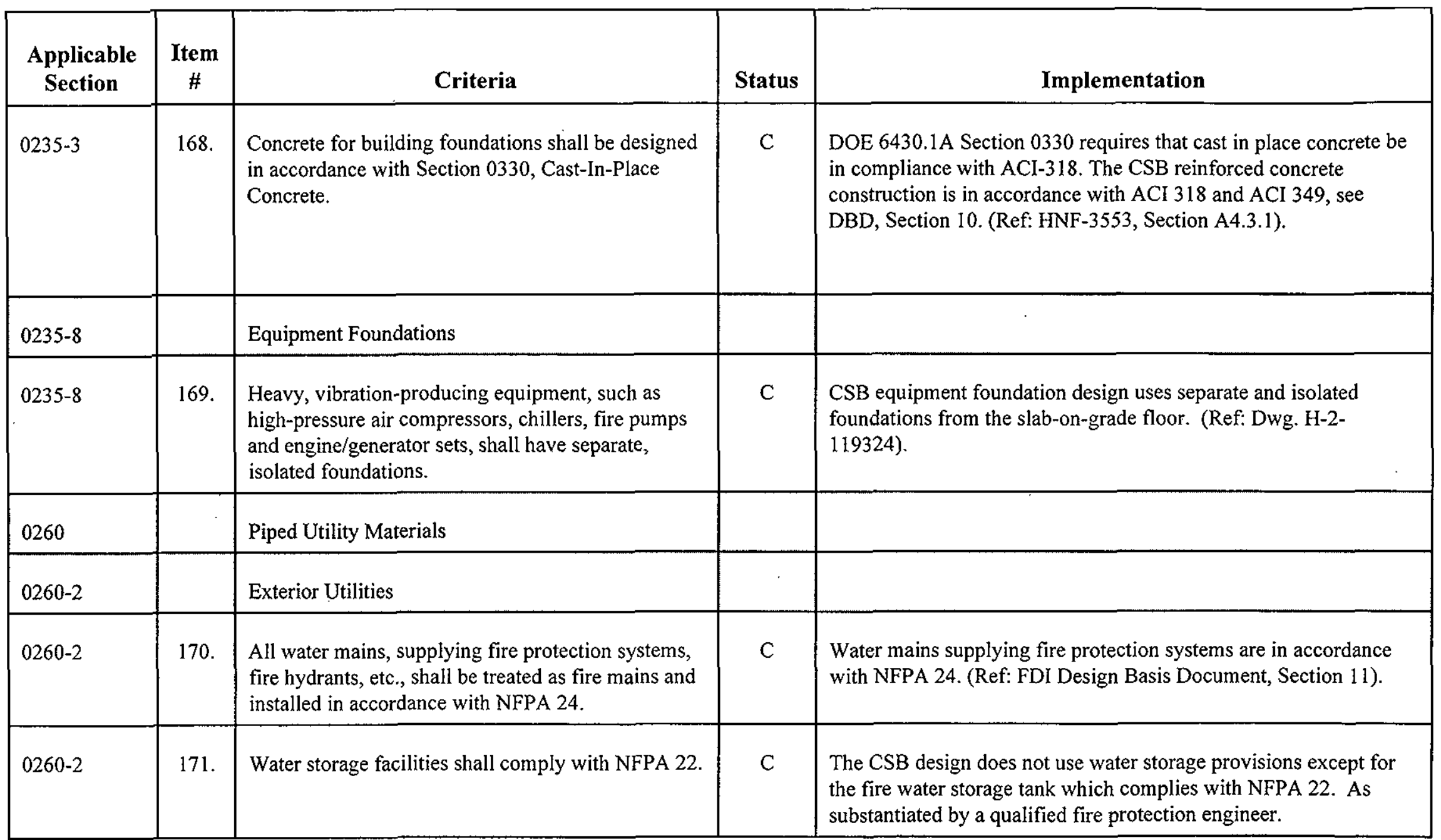




\section{Canister Storage Building Compliance Assessment \\ DOE Order 6430.1A, General Design Criteria}

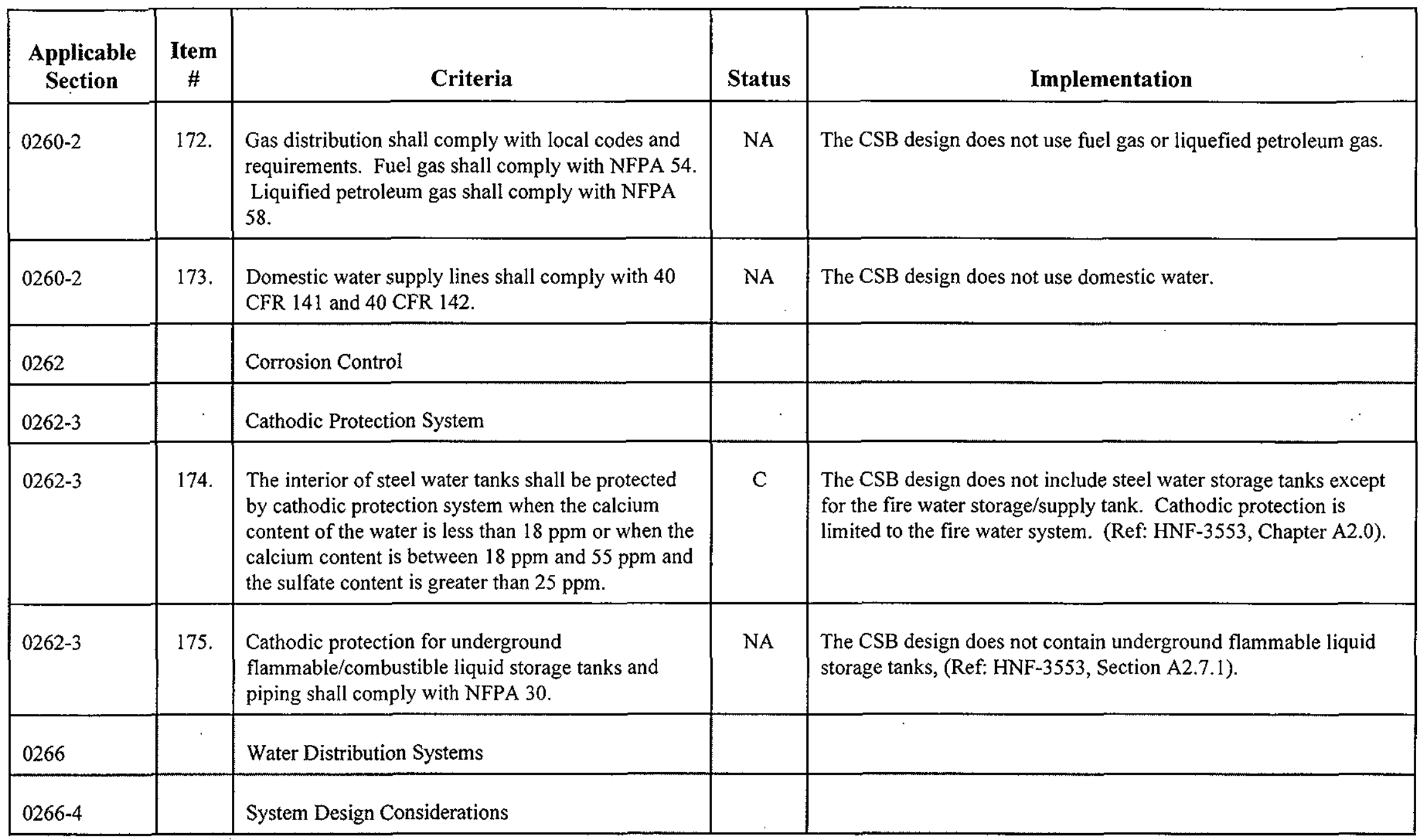




\section{Canister Storage Building Compliance Assessment \\ DOE Order 6430.1A, General Design Criteria}

HNF-4742, Rev. 0

\begin{tabular}{|c|c|c|c|c|}
\hline $0266-4$ & 177. & $\begin{array}{l}\text { Each fire hydrant within the distribution system } \\
\text { must be capable of delivering } 1000 \text { gpm at a } \\
\text { residual pressure of not less than } 10 \mathrm{psi} \text {. }\end{array}$ & $\mathrm{C}$ & $\begin{array}{l}\text { The fire hydrants have been tested and provide } 1800 \text { to } 2000 \mathrm{gpm} \text {. } \\
\text { Line pressure (pumped from the fire water pump house) is about } \\
125 \text { psig. }\end{array}$ \\
\hline $0266-4$ & 178. & $\begin{array}{l}\text { Where domestic water distribution systems are to } \\
\text { serve internal fire protection systems (i.e., sprinklers } \\
\text { or foamite systems), adequate residual pressures } \\
\text { shall be maintained for proper operation of such fire } \\
\text { protection systems. }\end{array}$ & NA & $\begin{array}{l}\text { The CSB design does not have a domestic water distribution } \\
\text { system. (Ref: HNF-3553, Chapter A2.0). }\end{array}$ \\
\hline $0266-4$ & 179. & $\begin{array}{l}\text { Fire hydrant branches (from main to hydrant) shall } \\
\text { be not less than } 6 \text { inches in diameter and no longer } \\
\text { than } 300 \text { feet. }\end{array}$ & $\mathrm{C}$ & $\begin{array}{l}\text { The fire hydrant branches are } 6 " \text { diameter pipe, at distances of } 20 \text {, } \\
25 \text {, and } 150 \text { feet from the } 10^{\prime \prime} \text { and } 12 \text { " diameter fire water mains. }\end{array}$ \\
\hline $0266-4$ & 180 & $\begin{array}{l}\text { A gate valve shall be installed within each fire } \\
\text { hydrant branch to facilitate maintenance. }\end{array}$ & C & $\begin{array}{l}\text { Each fire hydrant has a gate valve with a post indicator for shutting } \\
\text { off flow to the hydrant. }\end{array}$ \\
\hline $0266-4$ & 181. & $\begin{array}{l}\text { Fire hydrants shall be installed at a maximum } \\
\text { spacing of } 400 \text { feet. Fire hydrants shall not be } \\
\text { located more than } 300 \text { feet from the buildings to be } \\
\text { protected. }\end{array}$ & C & $\begin{array}{l}\text { Hose lay distances from three hydrants to exterior portions of the } \\
\text { building are not more than } 300 \text { feet. The fire hydrants are spaced } \\
437 \text { and } 370 \text { feet apart. The two fire hydrants separated by } 370 \text { feet } \\
\text { satisfy this requirement (Note item \#182). (Ref: HNF-3553, Figure } \\
\text { A2-4, and Design Basis Document, Section 11.8.1). }\end{array}$ \\
\hline
\end{tabular}




\section{Canister Storage Building Compliance Assessment \\ DOE Order 6430.1A, General Design Criteria}

HNF-4742, Rev. 0

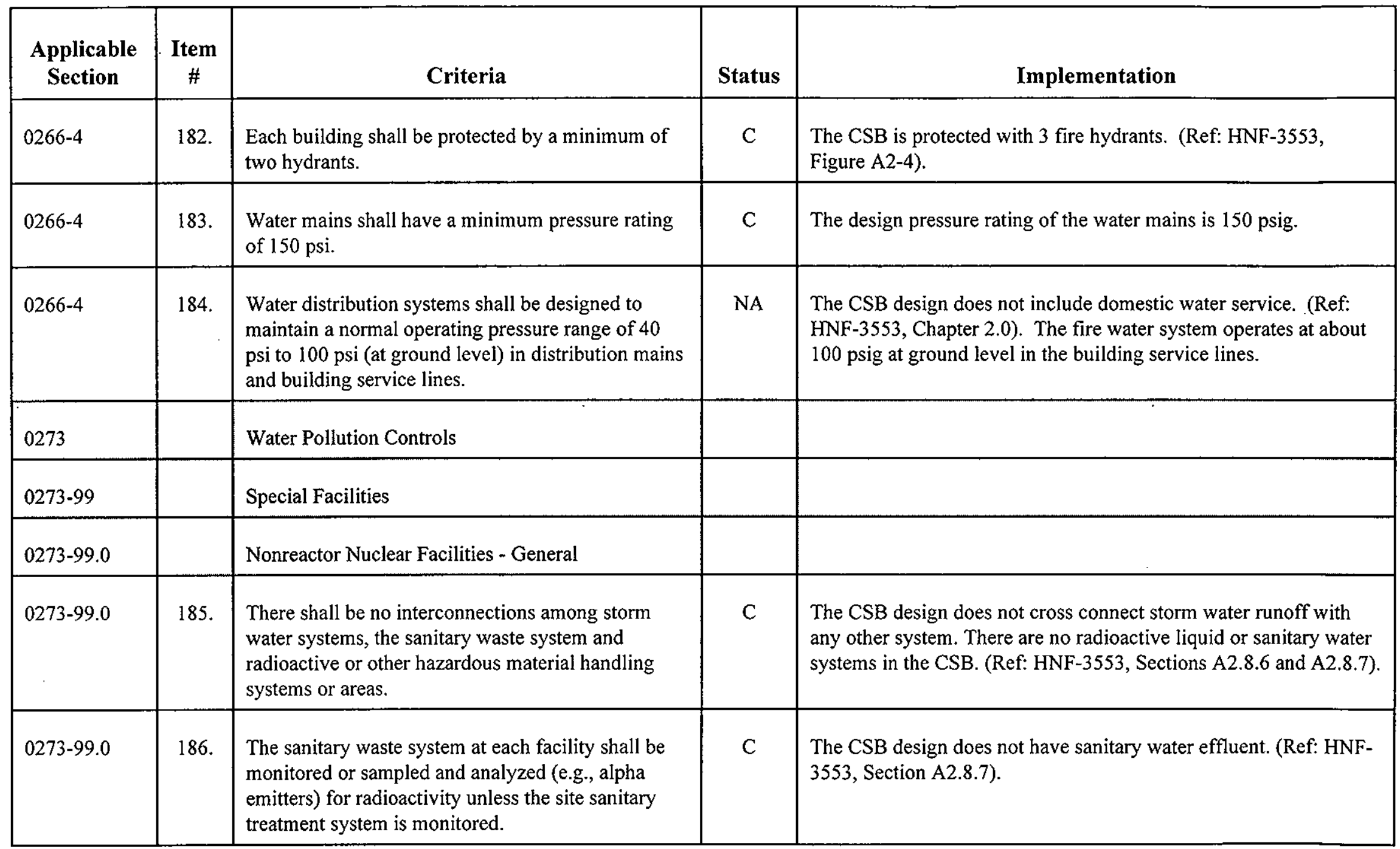




\section{Canister Storage Building Compliance Assessment \\ DOE Order 6430.1A, General Design Criteria}

HNF-4742, Rev. 0

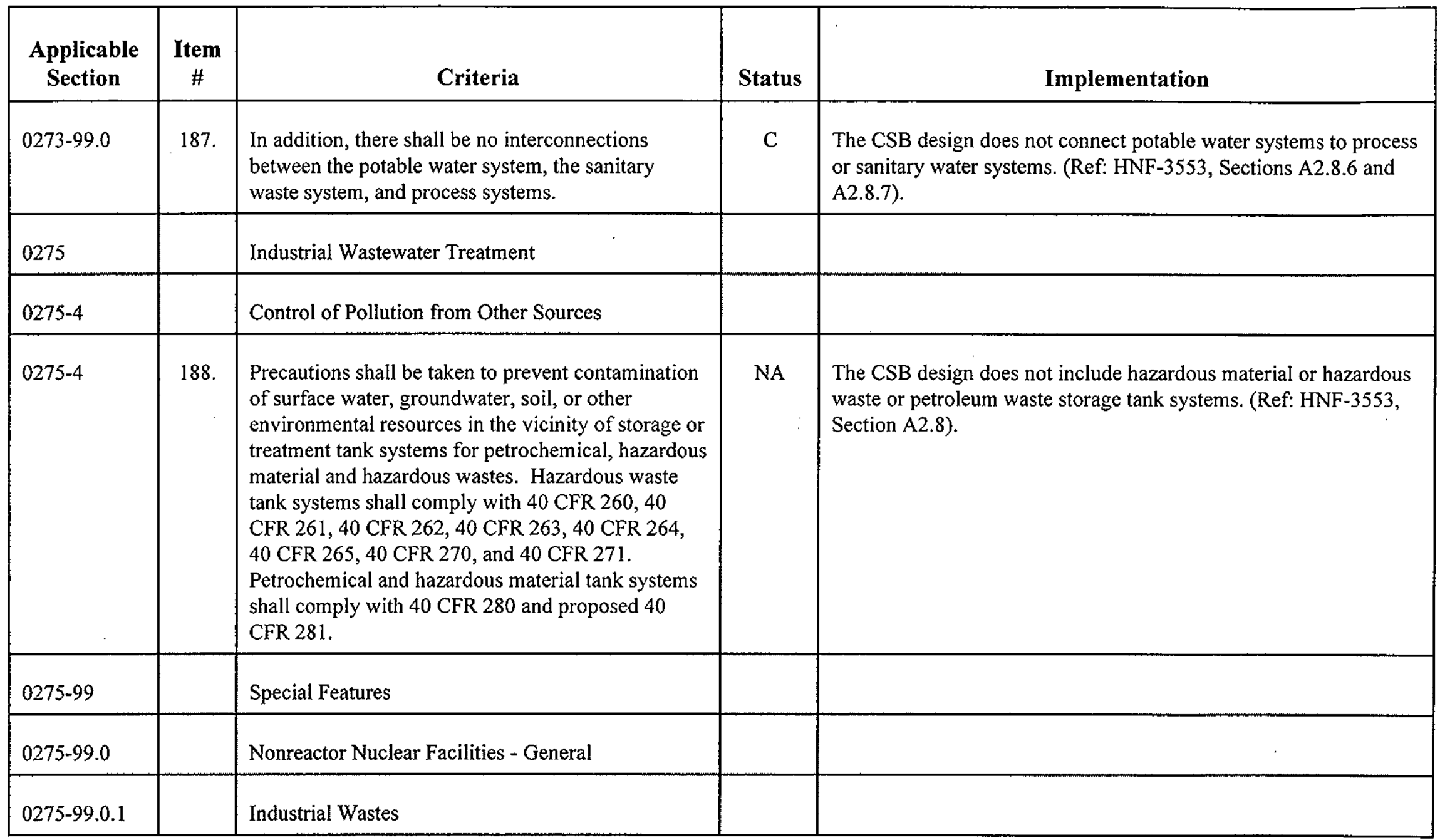




\section{Canister Storage Building Compliance Assessment \\ DOE Order 6430.1A, General Design Criteria}

HNF-4742, Rev. 0

\begin{tabular}{|c|c|c|c|c|}
\hline $\begin{array}{l}\text { Applicable } \\
\text { Section }\end{array}$ & $\begin{array}{l}\text { Item } \\
\#\end{array}$ & Criteria & Status & Implementation \\
\hline $0275-99.0 .1$ & 190. & $\begin{array}{l}\text { Provisions shall be made for the continuous } \\
\text { monitoring and recording of radioactivity, flow } \\
\text { volume, pH, and other parameters required for } \\
\text { material control and proper waste treatment } \\
\text { operations while each volume of waste is being } \\
\text { received by the plant. }\end{array}$ & $\mathrm{C}$ & $\begin{array}{l}\text { The transfer of liquid waste from the CSB to the treatment plant is } \\
\text { by batch (nominally } 55 \text { gal). Sampling of the batches will be } \\
\text { performed before shipping to the treatment plant. (Ref: HNF-3553, } \\
\text { Section A2.8.6). }\end{array}$ \\
\hline $0275-99.0 .2$ & & Process Wastes & & \\
\hline $0275-99.0 .2$ & 192. & $\begin{array}{l}\text { Liquid process wastes containing radioactive or } \\
\text { other hazardous material shall be collected and } \\
\text { monitored near the source of generation before } \\
\text { batch transfer through appropriate pipelines or tank } \\
\text { transfer to a liquid waste treatment plant or area. }\end{array}$ & $\mathrm{C}$ & $\begin{array}{l}\text { Liquid wastes are collected and sampled before transfer to a } \\
\text { treatment plant. (Ref: HNF-3553, Section A2.8.6). }\end{array}$ \\
\hline $0275-99.0 .2$ & 193. & $\begin{array}{l}\text { Waste storage tanks and transfer lines shall be } \\
\text { designed and constructed so that any leakage shall } \\
\text { be detected and contained before it reaches the } \\
\text { environment. }\end{array}$ & C & $\begin{array}{l}\text { Waste collection, storage or transfer is not by permanently installed } \\
\text { tanks or pipes. Liquid condensate is collected in a sump and } \\
\text { transferred to drums that are removed from the CSB. (Ref: HNF- } \\
3553 \text {, Section A2.8.6). }\end{array}$ \\
\hline
\end{tabular}




\section{Canister Storage Building Compliance Assessment \\ DOE Order 6430.1A, General Design Criteria}

HNF-4742, Rev. 0

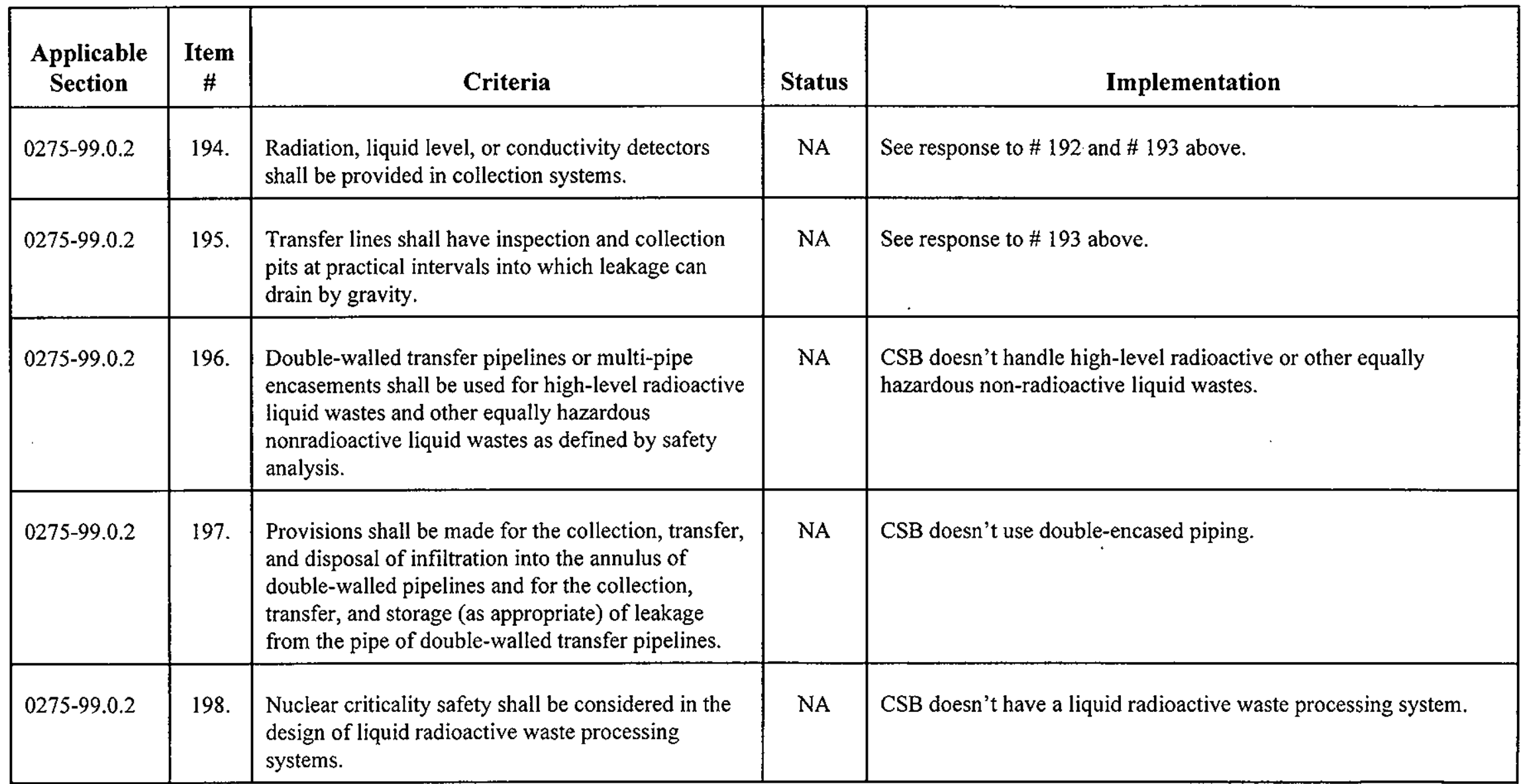




\section{Canister Storage Building Compliance Assessment \\ DOE Order 6430.1A, General Design Criteria}

HNF-4742, Rev. 0

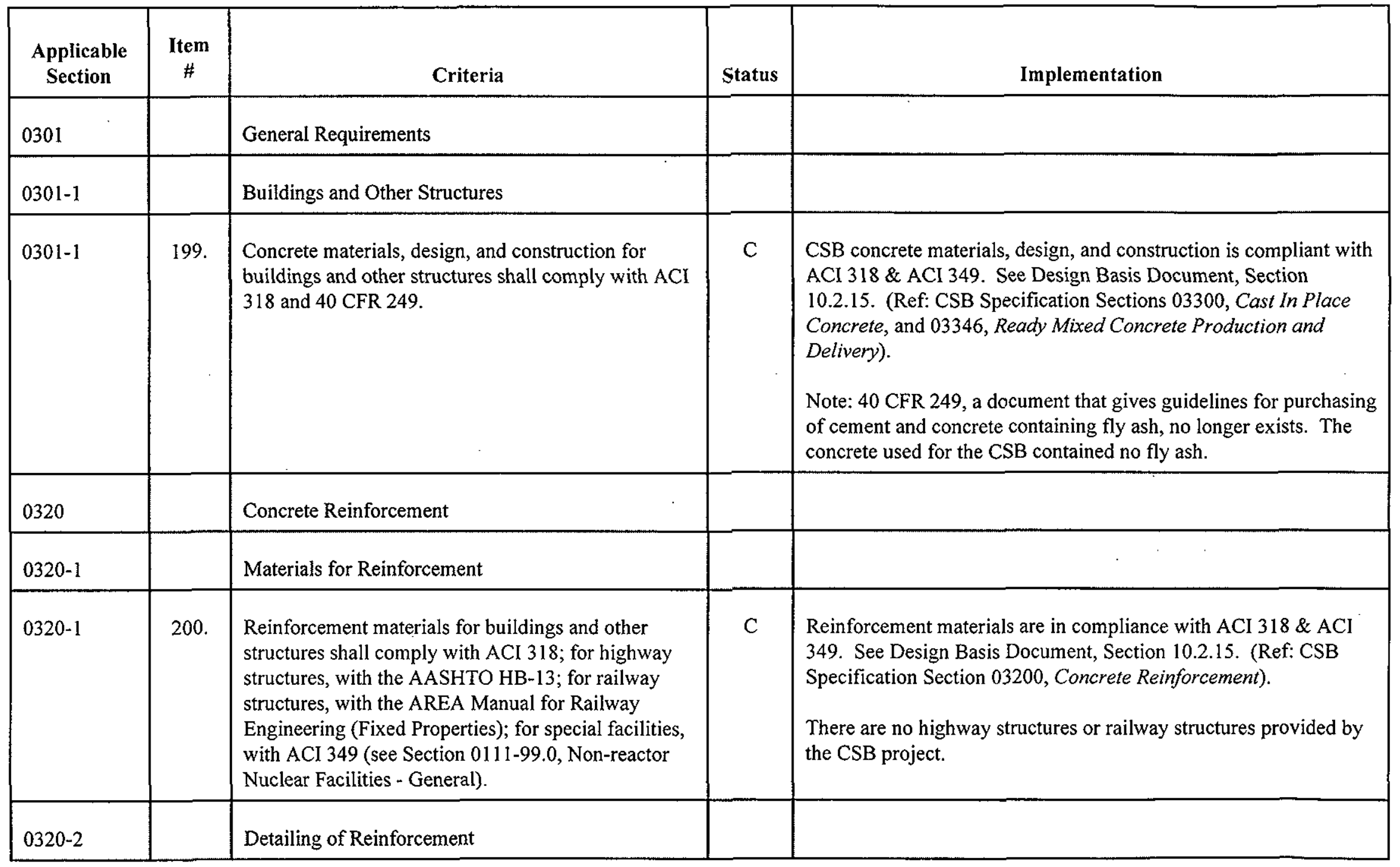




\section{Canister Storage Building Compliance Assessment DOE Order 6430.1A, General Design Criteria}

HNF-4742, Rev. 0

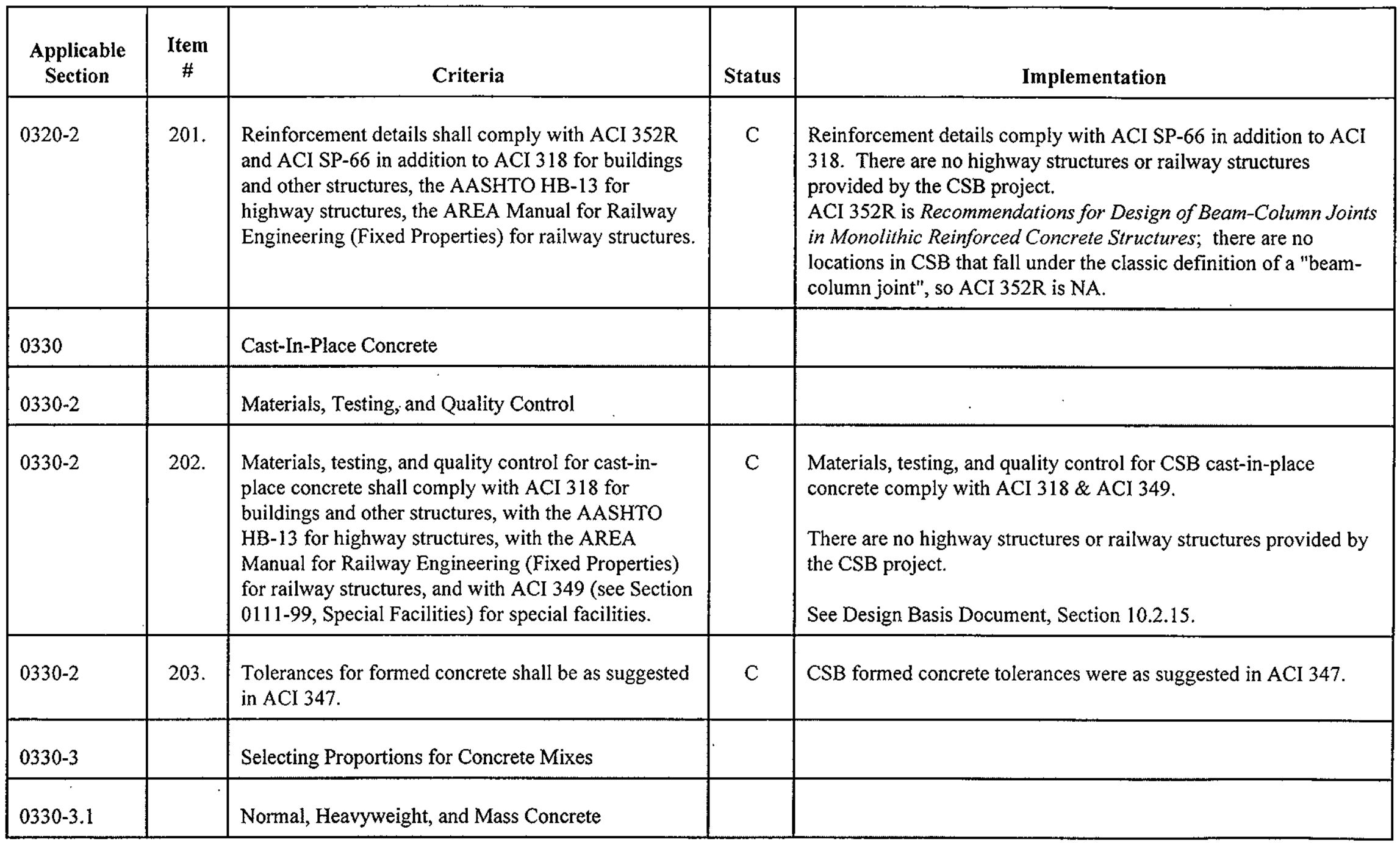




\section{Canister Storage Building Compliance Assessment \\ DOE Order 6430.1A, General Design Criteria}

HNF-4742, Rev. 0

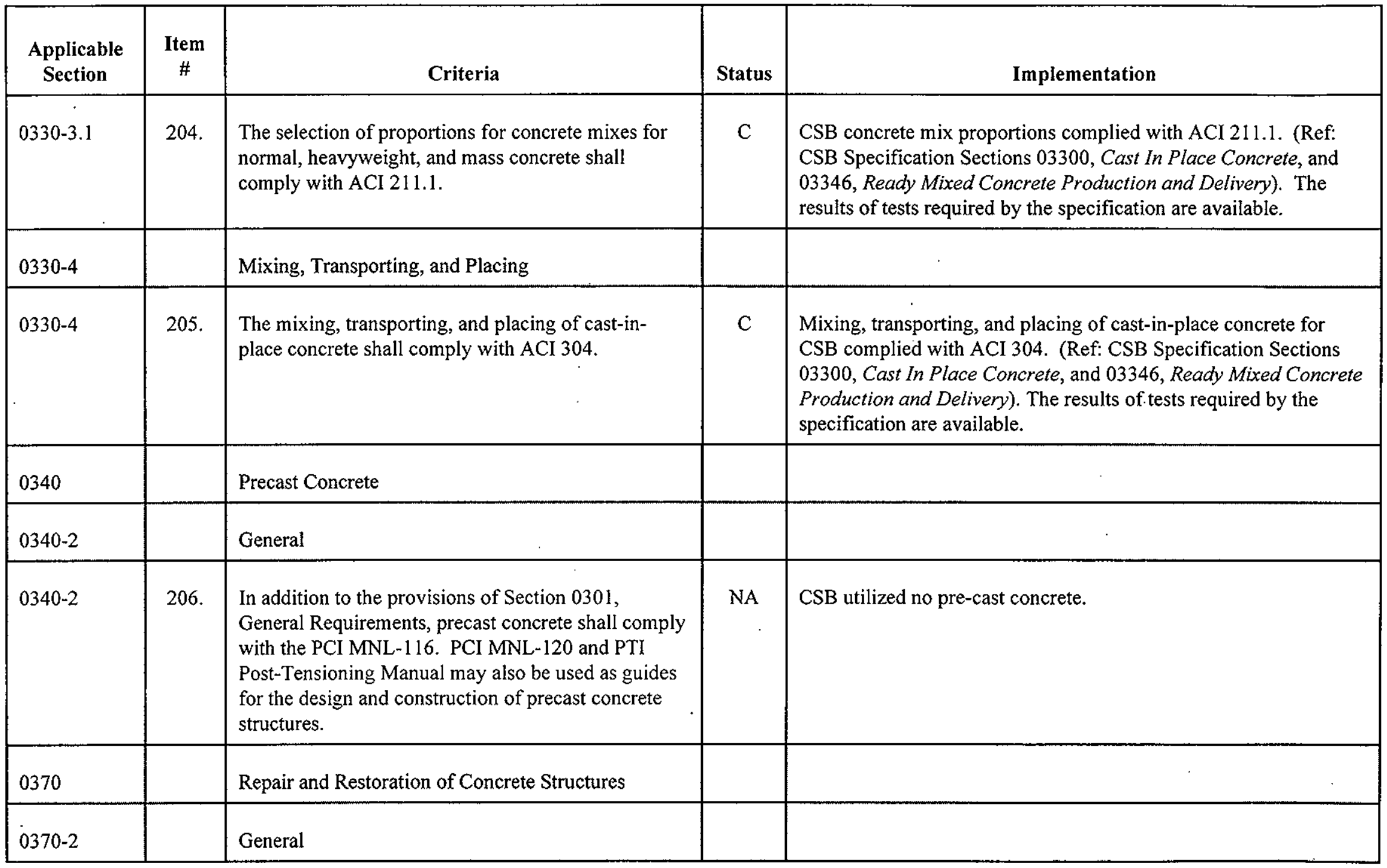




\section{Canister Storage Building Compliance Assessment \\ DOE Order 6430.1A, General Design Criteria}

HNF-4742, Rev. 0

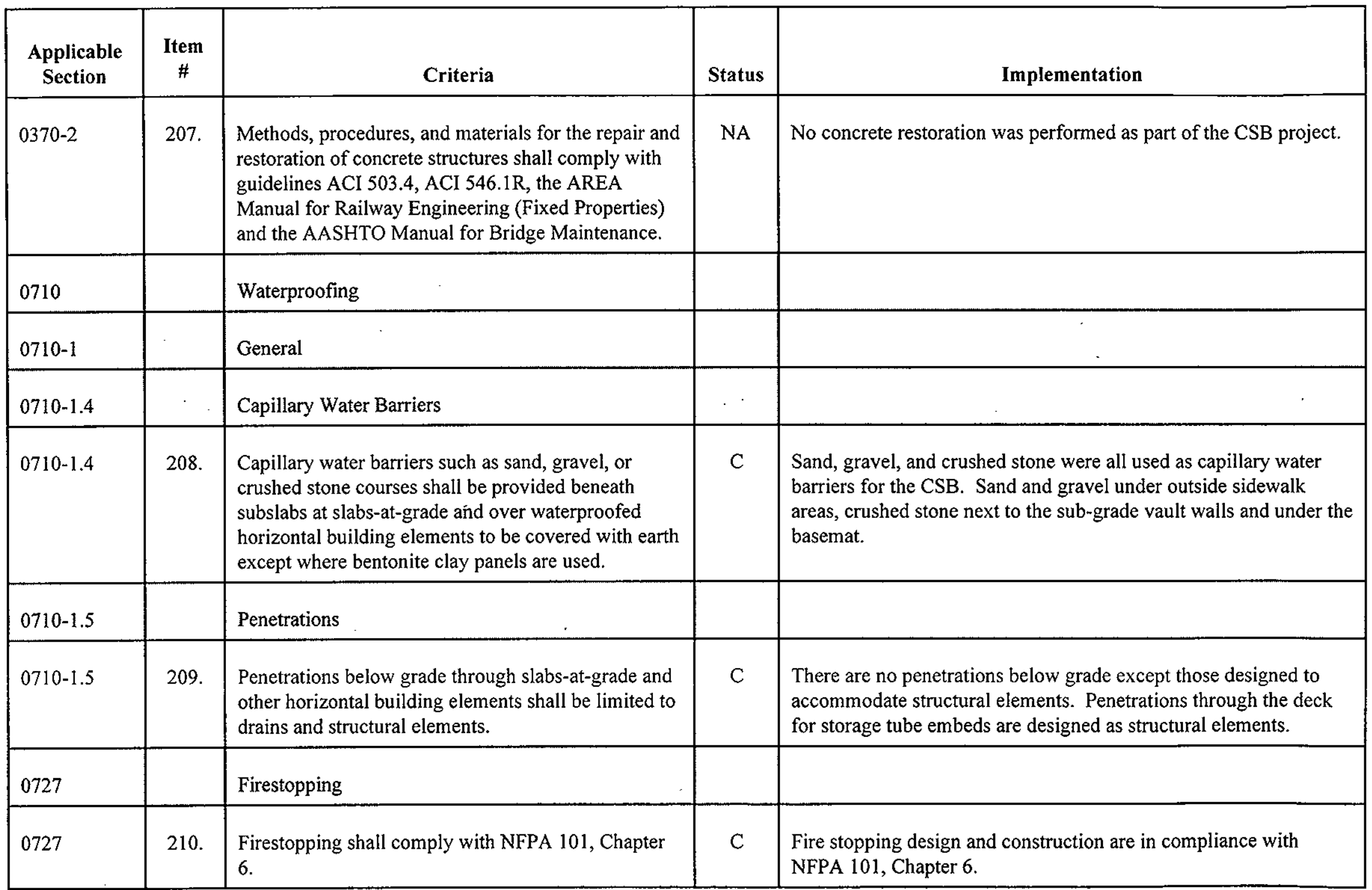




\section{Canister Storage Building Compliance Assessment \\ DOE Order 6430.1A, General Design Criteria}

HNF-4742, Rev. 0

\begin{tabular}{|c|c|c|c|c|}
\hline 0800 & & General & & \\
\hline $0800-1$ & & Doors & & \\
\hline $0800-1.2$ & & Fire Protection & & \\
\hline $0800-1.2$ & 213. & $\begin{array}{l}\text { Fire doors, frames, and hardware shall be installed } \\
\text { with label attached in accordance with NFPA } 80 \text {. }\end{array}$ & $\mathrm{C}$ & $\begin{array}{l}\text { Installation of these items in the firewall between the support } \\
\text { building and the operating area was with the compliant labels } \\
\text { attached. }\end{array}$ \\
\hline 0910 & & Metal Support Systems & & \\
\hline $0910-2$ & & Ceiling Suspension Systems & & . \\
\hline
\end{tabular}




\section{Canister Storage Building Compliance Assessment \\ DOE Order 6430.1A, General Design Criteria}

HNF-4742, Rev. 0

\begin{tabular}{|c|c|c|c|c|}
\hline 1161 & & Enclosures & & \\
\hline $1161-1$ & & General Considerations & & \\
\hline
\end{tabular}




\section{Canister Storage Building Compliance Assessment DOE Order 6430.1A, General Design Criteria}

\begin{tabular}{|c|c|c|c|c|}
\hline $\begin{array}{l}\text { Applicable } \\
\text { Section }\end{array}$ & $\begin{array}{c}\text { Item } \\
\#\end{array}$ & Criteria & Status & Implementation \\
\hline $1161-1$ & 217. & $\begin{array}{l}\text { The enclosure system, including its internal and } \\
\text { external support structures, shall be designed to } \\
\text { withstand the effects of normal operating conditions } \\
\text { and the environment. }\end{array}$ & $\mathrm{C}$ & $\begin{array}{l}\text { The enclosures mentioned in \# } 216 \text {, above, were designed to } \\
\text { withstand the effects of normal operating conditions and the } \\
\text { environment in which they operate. }\end{array}$ \\
\hline $1161-1$ & 218. & $\begin{array}{l}\text { Also, DBAs such as fire, explosion, criticality, and } \\
\text { natural phenomena shall be considered in the design } \\
\text { of the enclosure. }\end{array}$ & $\mathrm{C}$ & $\begin{array}{l}\text { All DBAs and NPH events (i.e., seismic, wind, rain, flooding, } \\
\text { ashfall, etc.) were considered in the design of the enclosures. The } \\
\text { DBAs do not impact primary design considerations of confinement } \\
\text { and structural integrity in intended use. }\end{array}$ \\
\hline
\end{tabular}




\section{Canister Storage Building Compliance Assessment DOE Order 6430.1A, General Design Criteria}

\begin{tabular}{|c|c|c|c|c|}
\hline $1161-1$ & 221. & $\begin{array}{l}\text { All equipment that must be located within the } \\
\text { enclosure shall be designed to allow for in place } \\
\text { maintenance and/or replacement. }\end{array}$ & $\mathrm{C}$ & $\begin{array}{l}\text { This guidance is complied with. For example, the MCO process } \\
\text { valve operator will be installed and removed within the Sample } \\
\text { Hood. Both the Sample Hood and the Weld Hoods can be } \\
\text { removed from service for maintenance of interior items. } \\
\text { There is not a regular program of maintenance and replacement for } \\
\text { the other three enclosure systems: } \\
\text { The Service Station Tent and the overpack tubes have no items } \\
\text { permanently installed inside. } \\
\text { The MHM cask is designed for in-place maintenance. } \\
\text { There is no equipment in the overpack storage tubes. }\end{array}$ \\
\hline $1161-1$ & 222. & $\begin{array}{l}\text { The design and operation of support and protection } \\
\text { systems, such as fire protection, shall not promote the } \\
\text { failure of the enclosure system integrity or the loss of } \\
\text { confinement. }\end{array}$ & $\mathrm{C}$ & $\begin{array}{l}\text { There are no support and protection systems capable of causing } \\
\text { impact upon the integrity of, or loss of confinement of the } \\
\text { enclosures mentioned in item } \# 216 \text {, above. The enclosures are all } \\
\text { located in the operating area, where there is no sprinkler system. }\end{array}$ \\
\hline
\end{tabular}




\section{Canister Storage Building Compliance Assessment \\ DOE Order 6430.1A, General Design Criteria}

HNF-4742, Rev. 0

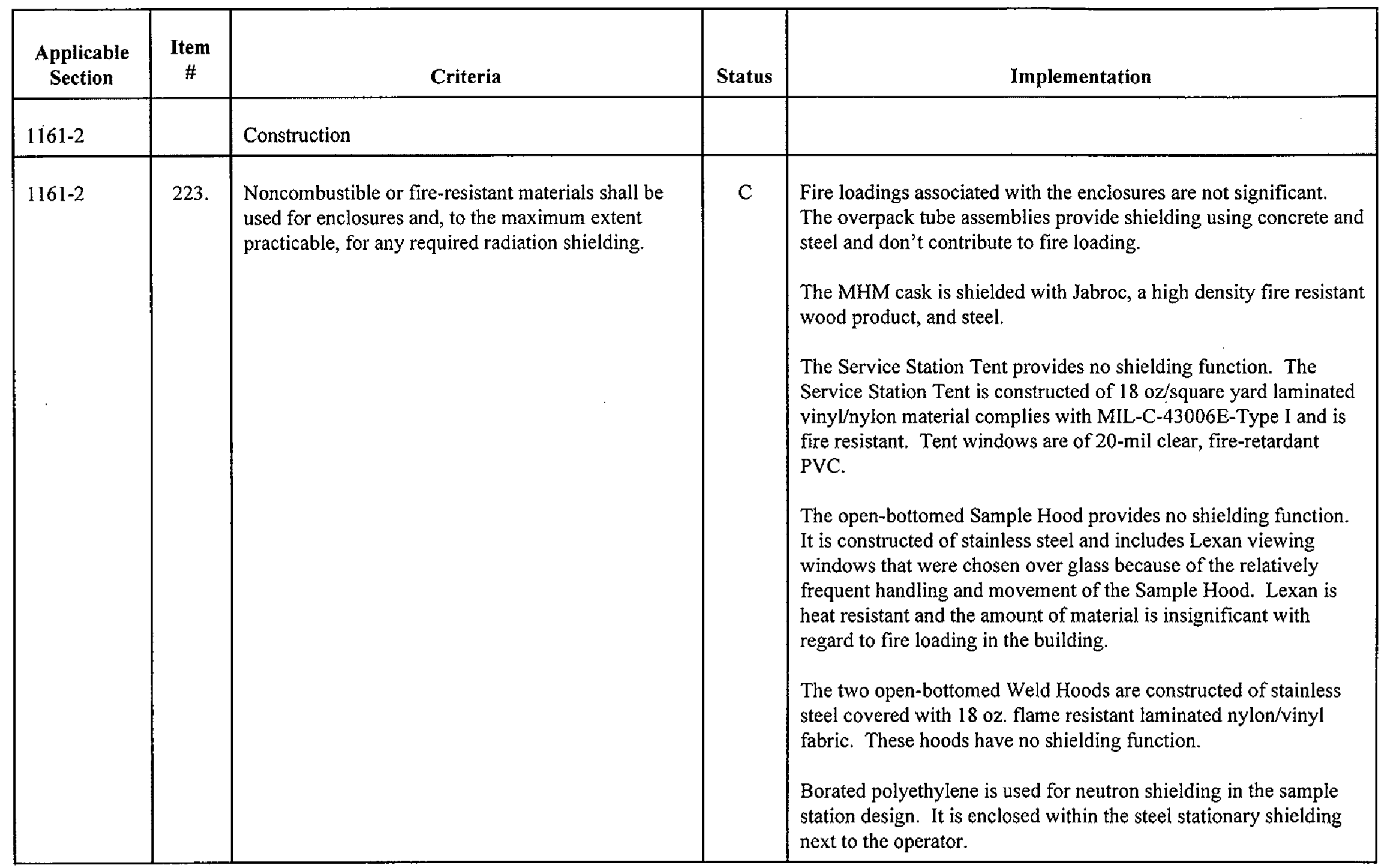




\section{Canister Storage Building Compliance Assessment DOE Order 6430.1A, General Design Criteria}

HNF-4742, Rev. 0

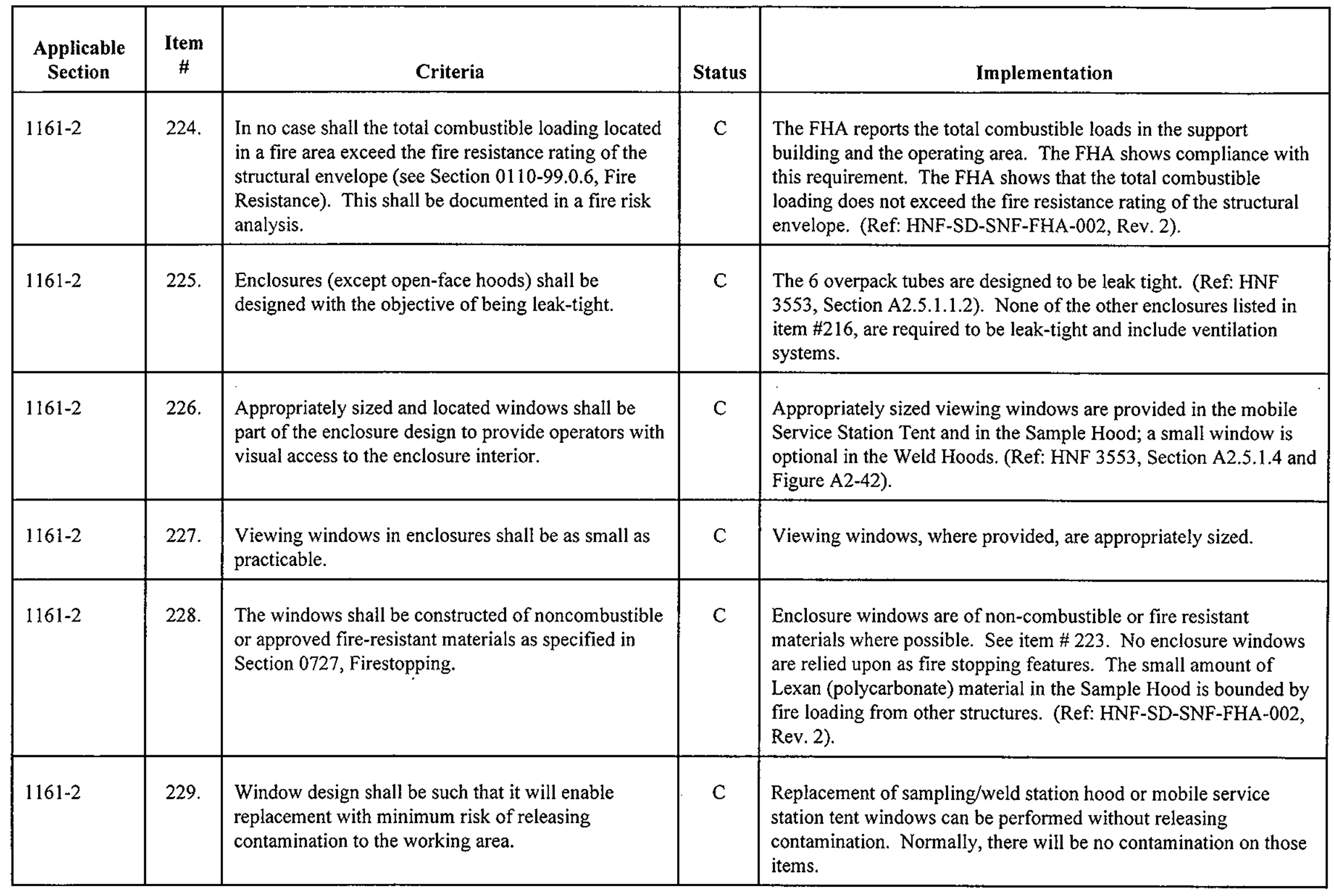




\section{Canister Storage Building Compliance Assessment \\ DOE Order 6430.1A, General Design Criteria}

HNF-4742, Rev. 0

\begin{tabular}{|c|c|c|c|c|}
\hline $1161-2$ & 231. & $\begin{array}{l}\text { Glove ports shall be located to facilitate both } \\
\text { operations and maintenance work inside the } \\
\text { enclosure. }\end{array}$ & C & $\begin{array}{l}\text { The Sample Hood is the only CSB enclosure provided with glove } \\
\text { ports. The glove ports are located to facilitate work within the } \\
\text { enclosure. (Ref: HNF-3553, Section A2.5.1.4). }\end{array}$ \\
\hline $1161-2$ & 232. & $\begin{array}{l}\text { They shall have flexible gloves attached to allow } \\
\text { operating personnel access to all interior surfaces and } \\
\text { equipment. }\end{array}$ & C & $\begin{array}{l}\text { Access is provided for all operations required within the Sample } \\
\text { Hood. The hood is removable and open on the bottom for } \\
\text { maintenance and decontamination. The gloves can be removed } \\
\text { from the hood. }\end{array}$ \\
\hline $1161-2$ & 233. & $\begin{array}{l}\text { They shall be designed to allow replacement of } \\
\text { gloves without losing contamination control and with } \\
\text { minimum exposure to the operator. }\end{array}$ & C & $\begin{array}{l}\text { Because the sample hood is not closed on the bottom and is easily } \\
\text { removable for bag-out and decontamination, gloves can be } \\
\text { replaced without loss of contamination control and with minimal } \\
\text { exposure to the operator. Sweep air inflow is sufficient to confine } \\
\text { contamination to the hood in the event of a glove failure. }\end{array}$ \\
\hline $1161-2$ & 234. & $\begin{array}{l}\text { When gloves are not in place, a noncombustible } \\
\text { shield or cover for each glove port shall be provided. }\end{array}$ & C & $\begin{array}{l}\text { Gloveport shields or covers are provided by the sample hood } \\
\text { design. }\end{array}$ \\
\hline
\end{tabular}




\section{Canister Storage Building Compliance Assessment DOE Order 6430.1A, General Design Criteria}

HNF-4742, Rev. 0

\begin{tabular}{|c|c|l|c|l|}
\hline $\begin{array}{c}\text { Applicable } \\
\text { Section }\end{array}$ & $\begin{array}{c}\text { Item } \\
\text { \# }\end{array}$ & Criteria & Status & Implementation \\
\hline $1161-2$ & 235. & $\begin{array}{l}\text { To reduce migration of contamination, closure } \\
\text { devices or permanent seals shall be provided on } \\
\text { entrances and exits of piping, ducts, or conduits } \\
\text { penetrating confinement barriers. }\end{array}$ & C & $\begin{array}{l}\text { The sealed enclosures are the plug closure device that seals the } \\
\text { penetrations between the operations area and the interior of the } 6 \\
\text { overpack tubes/plugs are sealed. The other enclosures are not } \\
\text { designed to be leak tight and rely on air sweep to reduce migration } \\
\text { of contamination. } \\
\text { The penetrations between the Service Station Tent and the } \\
\text { operating area are through the HEPA filters, or are small and } \\
\text { subjected to negative pressure relative to the operating area. }\end{array}$ \\
\hline $1161-2$ & 236. & $\begin{array}{l}\text { Such closures or seals shall have an integrity equal to } \\
\text { or greater than the barrier itself. }\end{array}$ & C & $\begin{array}{l}\text { See item \# 235, above. The penetration seals for the overpack tube } \\
\text { assemblies are valved or capped pipes welded to the plug body. } \\
\text { Double o-rings and tight sealing valves form the barrier. The } \\
\text { integrity of the overpack tube assembly sealing system is } \\
\text { demonstrated through testing and surveillance. }\end{array}$ \\
\hline
\end{tabular}




\section{Canister Storage Building Compliance Assessment DOE Order 6430.1A, General Design Criteria}

HNF-4742, Rev. 0

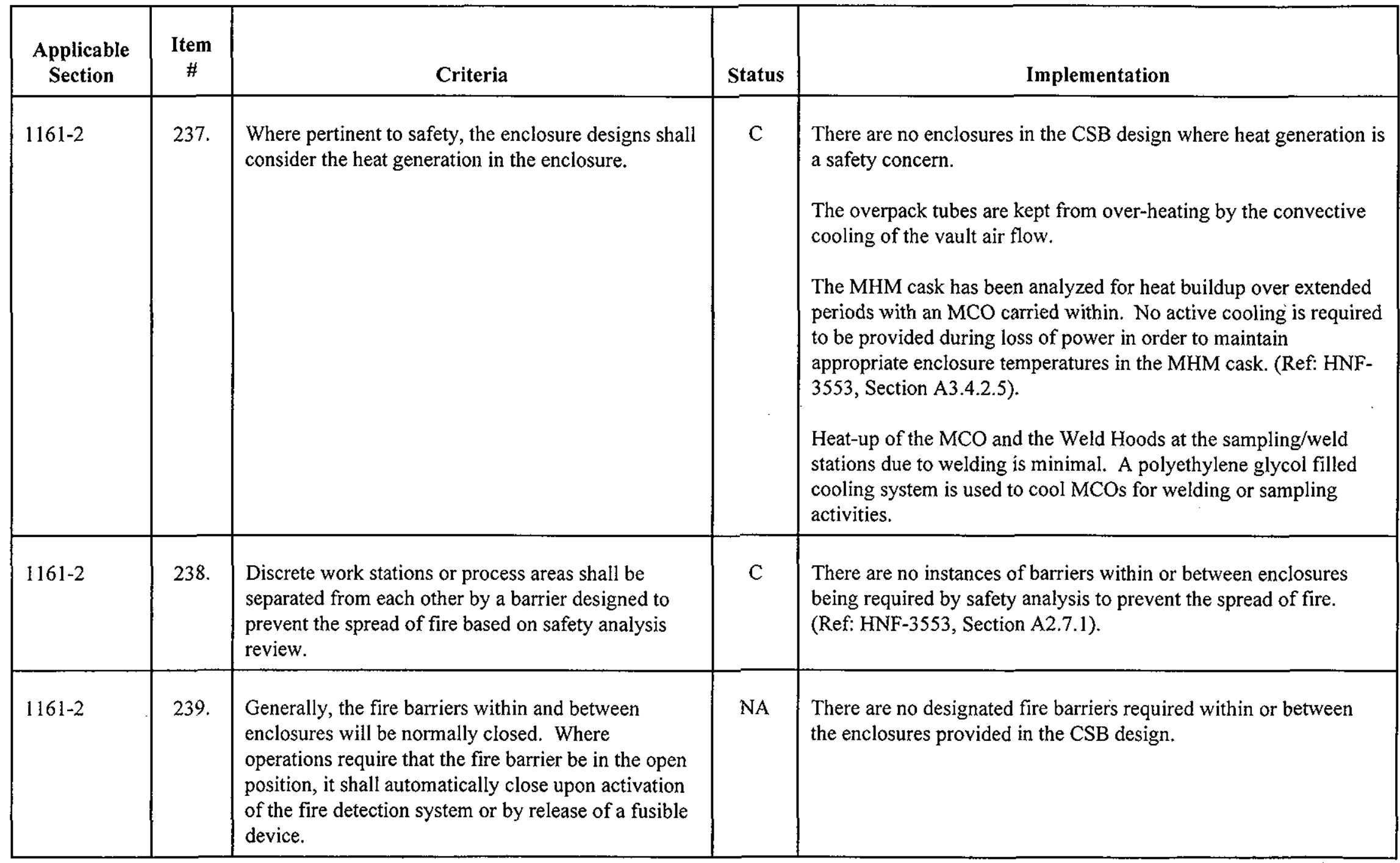




\section{Canister Storage Building Compliance Assessment \\ DOE Order 6430.1A, General Design Criteria}

HNF-4742, Rev. 0

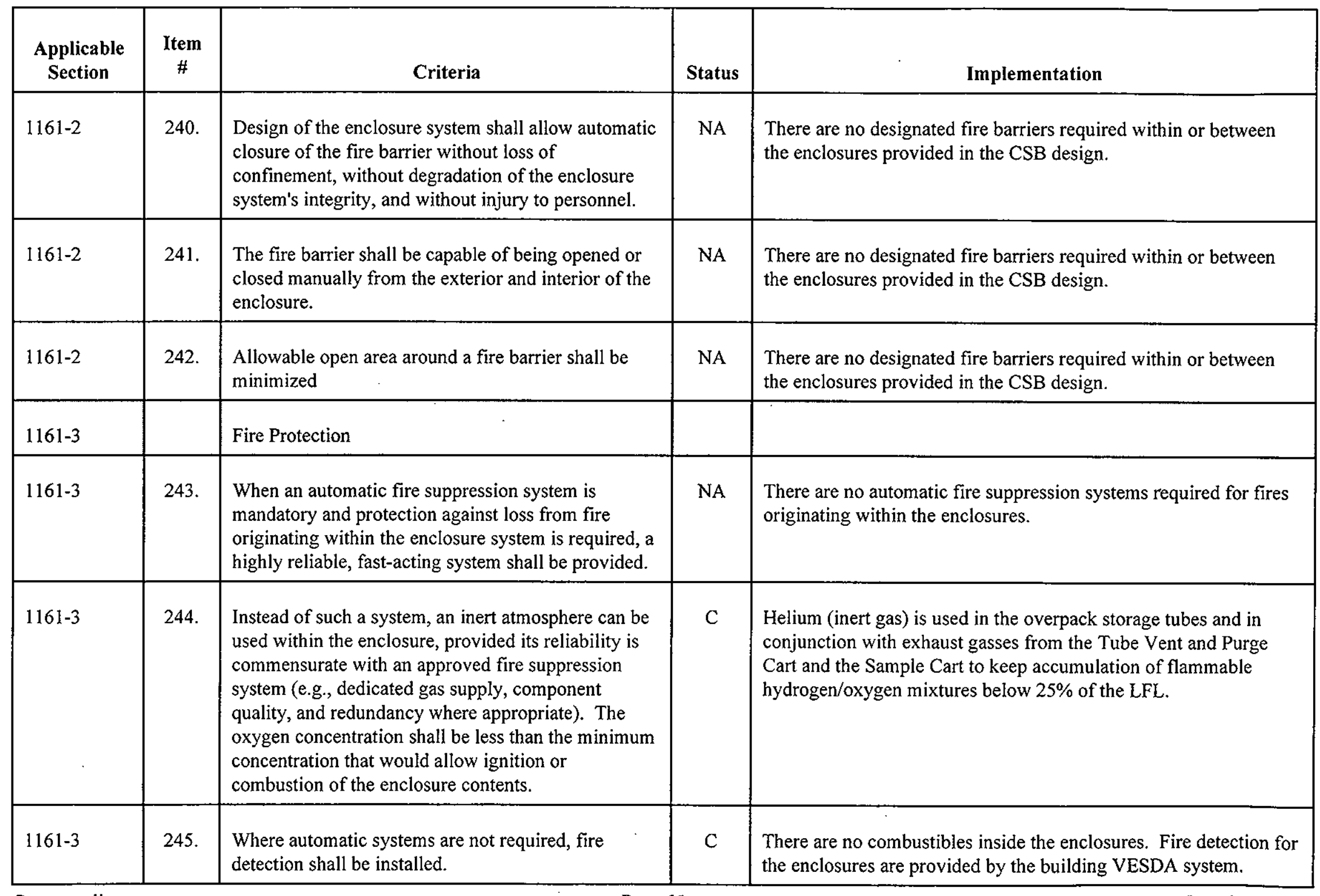




\section{Canister Storage Building Compliance Assessment DOE Order 6430.1A, General Design Criteria}

HNF-4742, Rev. 0

\begin{tabular}{|c|c|c|c|c|}
\hline $1161-3$ & 247. & $\begin{array}{l}\text { Fire detection systems shall be integrated with any } \\
\text { central alarm location and any associated automatic } \\
\text { fire suppression systems. }\end{array}$ & $\mathrm{C}$ & $\begin{array}{l}\text { The VESDA system in the operating area and the fire detection } \\
\text { system associated with the sprinkler system in the support area are } \\
\text { integrated with the Hanford site central alarm station. }\end{array}$ \\
\hline $1161-4$ & & Ventilation & & \\
\hline $1161-4$ & 248. & $\begin{array}{l}\text { A ventilation system shall be installed on all } \\
\text { enclosure systems to maintain minimum negative } \\
\text { pressure differential of } 0.3 \text { in. of water inside the } \\
\text { enclosure (except open-face hoods) with respect to } \\
\text { the operating area. }\end{array}$ & $\mathrm{C}$ & $\begin{array}{l}\text { The MHM cask will be maintained at a minimum differential } \\
\text { negative pressure of } 0.3 \text { in. of water with respect to the operating } \\
\text { area whenever an MCO is contained therein. } \\
\text { The mobile service station tent is designed to maintain a minimum } \\
\text { negative pressure with respect to the operating area of } 0.5 \text { inches of } \\
\text { water. Normal operations are expected to be at a minimum of } 0.25 \\
\text { inches of water. (Ref: HNF-3553, Section A2.5.1.2). } \\
\text { The Sample Hood and the Weld Hoods are functionally "open- } \\
\text { face" hoods, that rely on air-sweep to reduce migration of } \\
\text { contamination. } \\
\text { Note: } \\
\text { The six overpack storage assemblies are maintained at about } 5 \text { psig } \\
\text { positive pressure for the inert gas function required by NFPA } 69 \text {. }\end{array}$ \\
\hline $1161-4$ & 249. & $\begin{array}{l}\text { Open-face hoods shall be ventilated such that flow } \\
\text { from the operating area into the hood is maintained. }\end{array}$ & $\mathrm{C}$ & $\begin{array}{l}\text { The Sample Hood and Weld Hoods maintain inward airflow from } \\
\text { the operating area to capture contamination that could otherwise } \\
\text { escape to the operating area. }\end{array}$ \\
\hline
\end{tabular}




\section{Canister Storage Building Compliance Assessment \\ DOE Order 6430.1A, General Design Criteria}

HNF-4742, Rev. 0

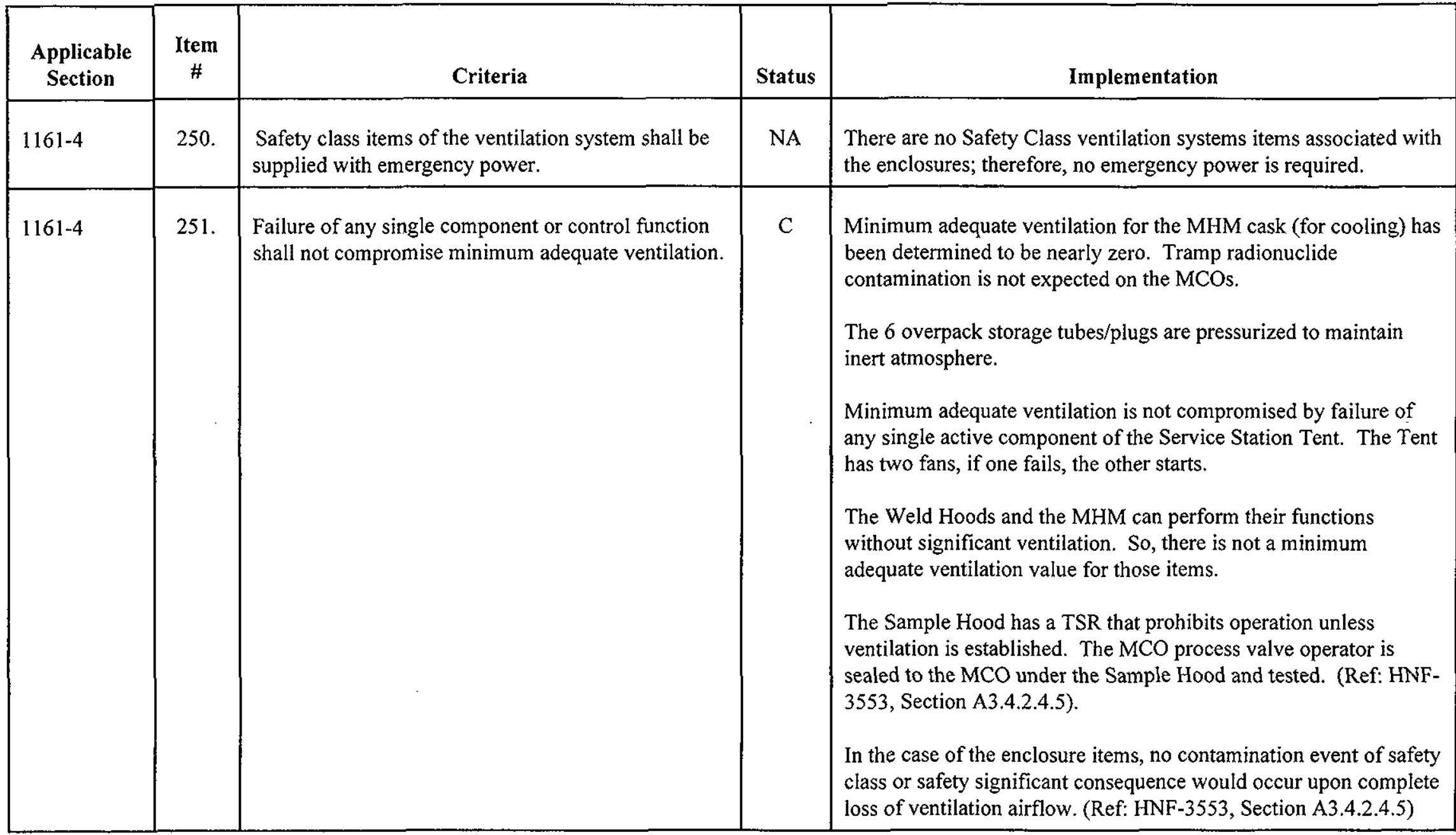




\section{Canister Storage Building Compliance Assessment DOE Order 6430.1A, General Design Criteria}

HNF-4742, Rev. 0

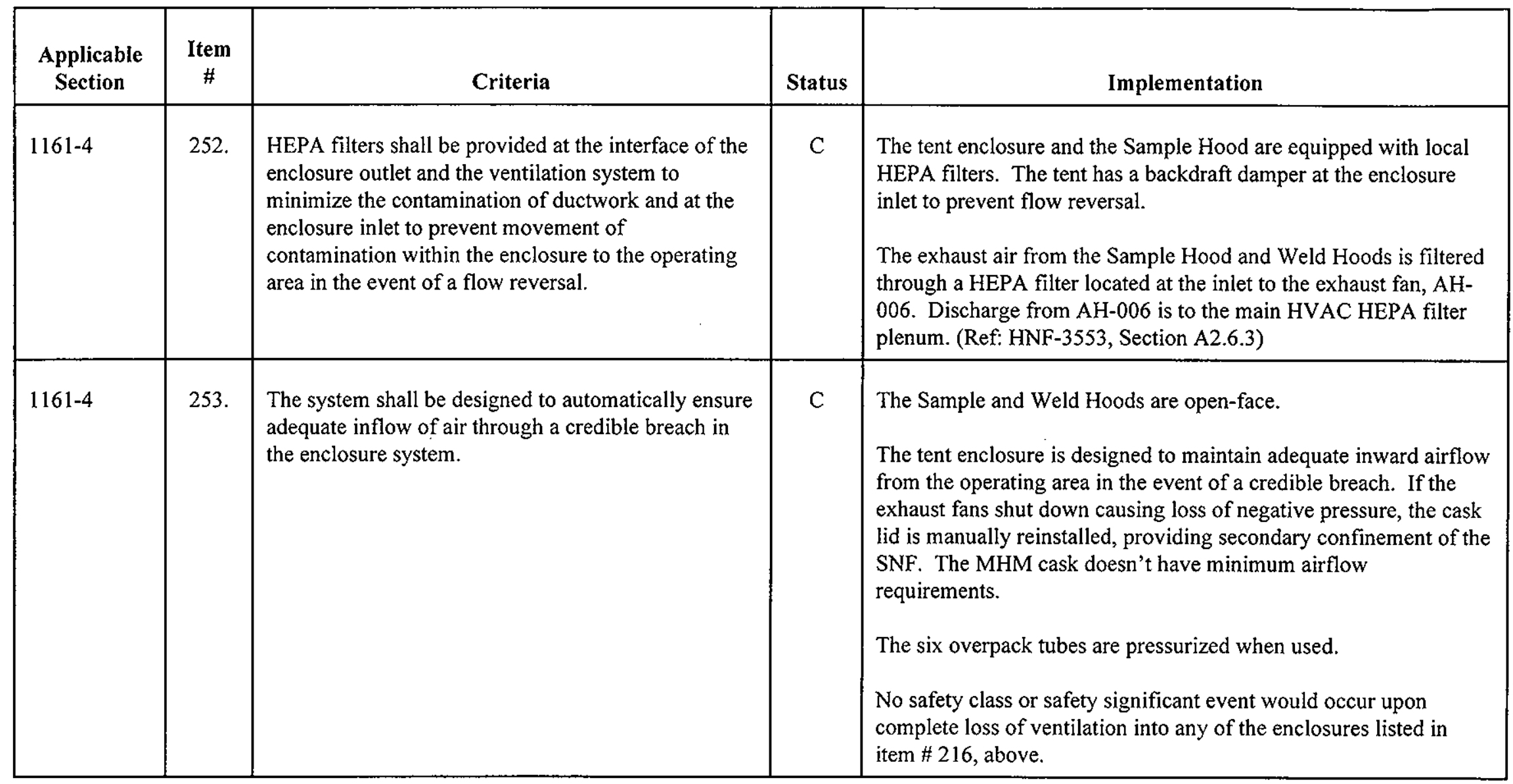




\section{Canister Storage Building Compliance Assessment \\ DOE Order 6430.1A, General Design Criteria}

HNF-4742, Rev. 0

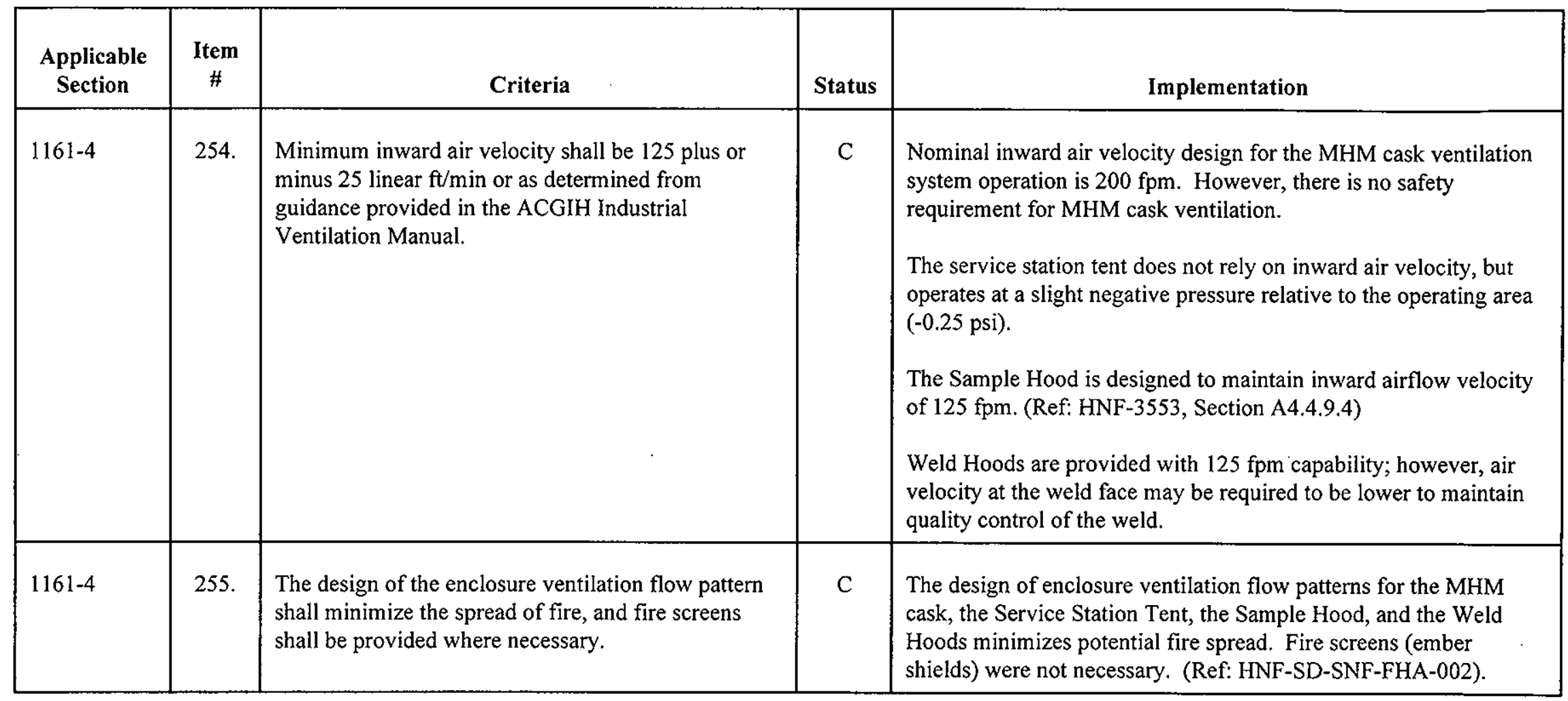




\section{Canister Storage Building Compliance Assessment DOE Order 6430.1A, General Design Criteria}

\begin{tabular}{|c|c|c|c|c|}
\hline $1161-4$ & 258 & $\begin{array}{l}\text { Hood faces shall not be located within } 10 \mathrm{ft} \text {. of the } \\
\text { closest air supply or exhaust point. Hoods shall not } \\
\text { be located in or along normal traffic routes. }\end{array}$ & C & $\begin{array}{l}\text { Building HVAC inlet and exhaust points are distant (much farther } \\
\text { than } 10 \mathrm{ft} \text {.) from the Sample and Weld Hoods. The only nearby } \\
\text { traffic is associated with Sampling Station and/or Weld Station } \\
\text { operations. }\end{array}$ \\
\hline $1161-4$ & 259. & $\begin{array}{l}\text { An open-faced hood shall be designed and located to } \\
\text { provide a minimum air velocity of } 125 \text { plus or minus } \\
25 \text { linear } \mathrm{ft} / \mathrm{min} \text { over the hood face area. }\end{array}$ & $\mathrm{C}$ & $\begin{array}{l}\text { The open-bottomed Sample Hood and Weld Hoods are provided } \\
\text { with } 125 \text { fpm capability; however, air velocity at the weld face } \\
\text { may be required to be lower to maintain quality control of the } \\
\text { weld. }\end{array}$ \\
\hline
\end{tabular}




\section{Canister Storage Building Compliance Assessment \\ DOE Order 6430.1A, General Design Criteria}

HNF-4742, Rev. 0

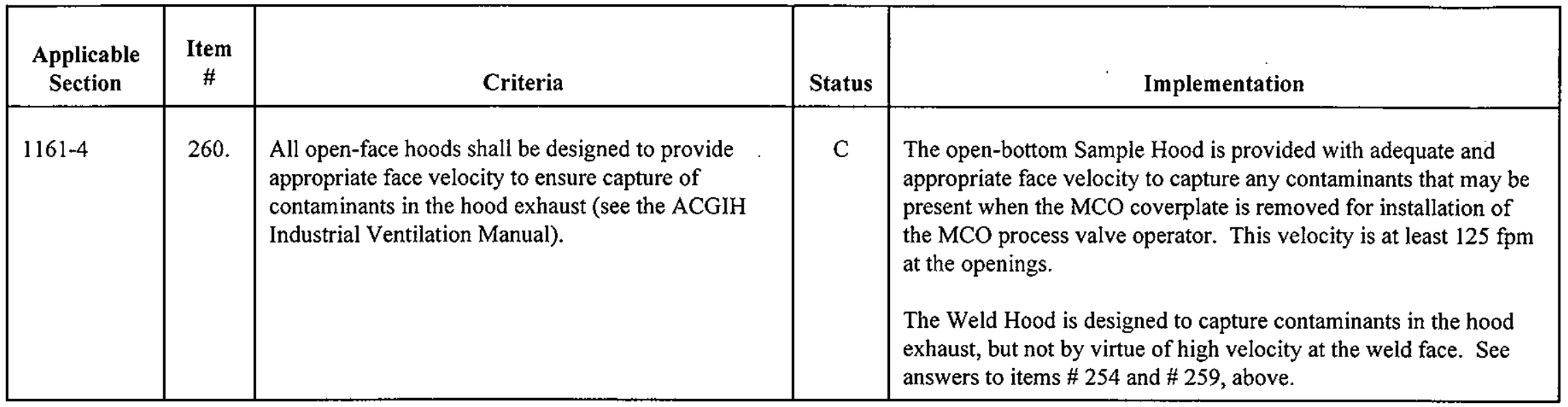




\section{Canister Storage Building Compliance Assessment \\ DOE Order 6430.1A, General Design Criteria}

HNF-4742, Rev. 0

\begin{tabular}{|c|c|c|c|c|}
\hline $\begin{array}{l}\text { Applicable } \\
\text { Section }\end{array}$ & $\begin{array}{c}\text { Item } \\
\#\end{array}$ & Criteria & Status & Implementation \\
\hline $1300-1$ & & Coverage and Objectives & & \\
\hline $1300-1.4 .1$ & & General & & \\
\hline $1300-1.4 .1$ & 261. & $\begin{array}{l}\text { The confinement of hazardous materials produced, } \\
\text { processed, or stored in special facilities shall be } \\
\text { designed to minimize dose to a maximally exposed } \\
\text { member of the public. }\end{array}$ & C & $\begin{array}{l}\text { CSB confinement systems are designed to minimize the release of } \\
\text { material to the environment. This was implemented by the MCO's } \\
\text { robust design and many safety features of the material handling } \\
\text { system including the MHM, the storage tubes and impact absorbers } \\
\text { that prevent damage to MCO confinement and the CSB secondary } \\
\text { confinement system. (Ref: HNF-3553 Chapter A2.0) }\end{array}$ \\
\hline
\end{tabular}




\section{Canister Storage Building Compliance Assessment DOE Order 6430.1A, General Design Criteria}

HNF-4742, Rev. 0

\begin{tabular}{|c|c|c|c|c|}
\hline $\begin{array}{l}\text { Applicable } \\
\text { Section }\end{array}$ & $\begin{array}{c}\text { Item } \\
\#\end{array}$ & Criteria & Status & Implementation \\
\hline $1300-1.4 .3$ & & Routine Releases & & \\
\hline
\end{tabular}




\section{Canister Storage Building Compliance Assessment \\ DOE Order 6430.1A, General Design Criteria}

HNF-4742, Rev. 0

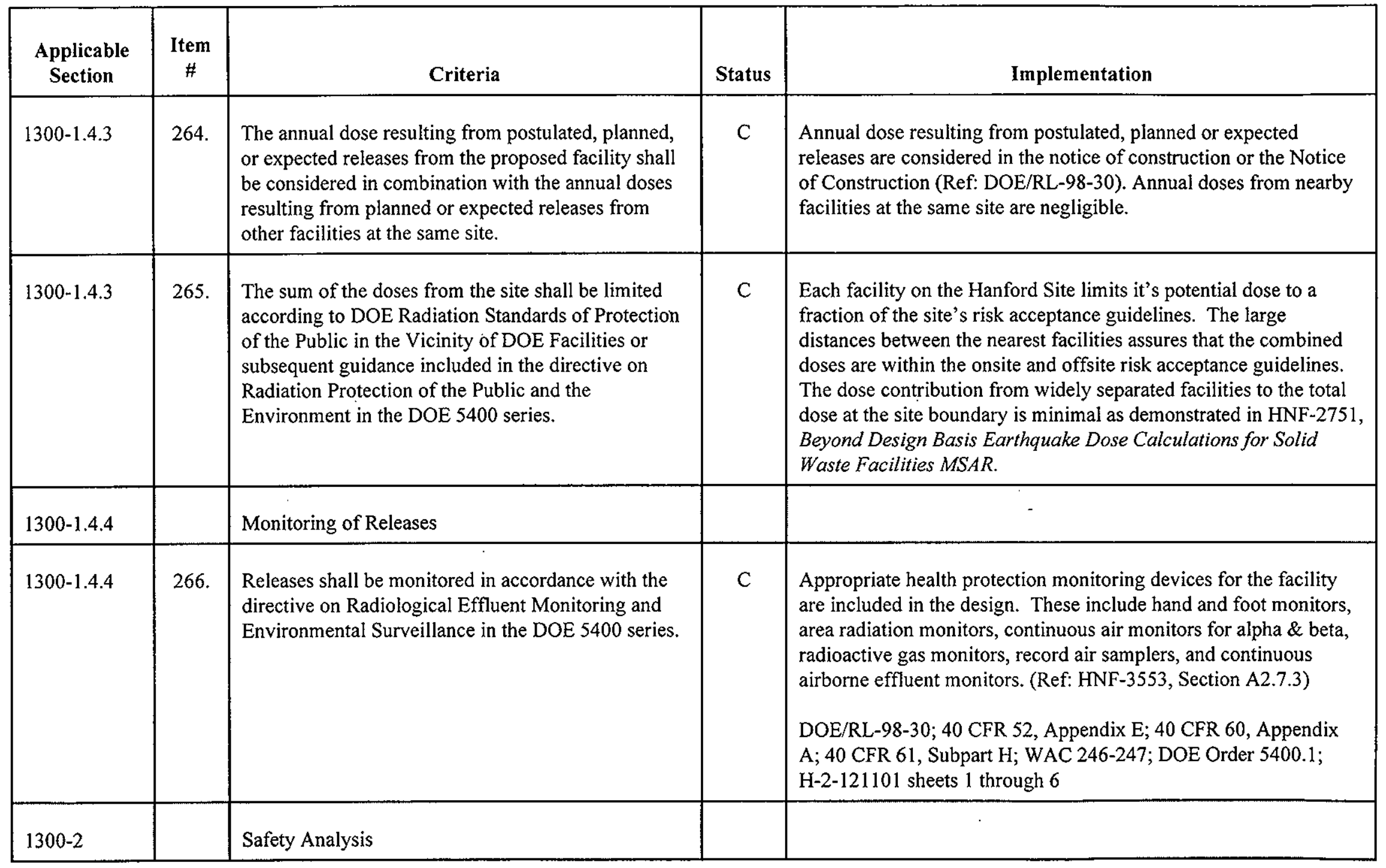




\section{Canister Storage Building Compliance Assessment}

HNF-4742, Rev. 0

\section{DOE Order 6430.1A, General Design Criteria}

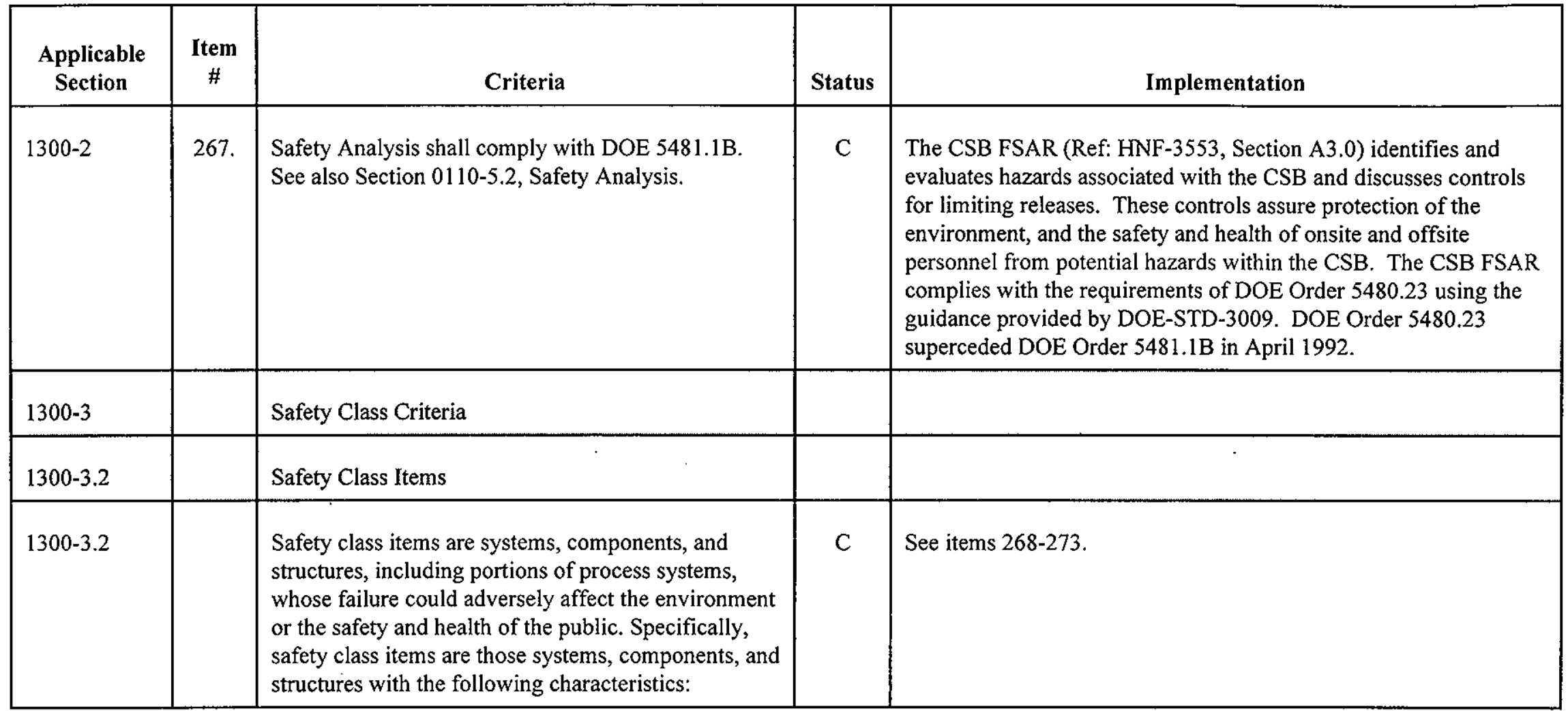




\section{Canister Storage Building Compliance Assessment \\ DOE Order 6430.1A, General Design Criteria}

HNF-4742, Rev. 0

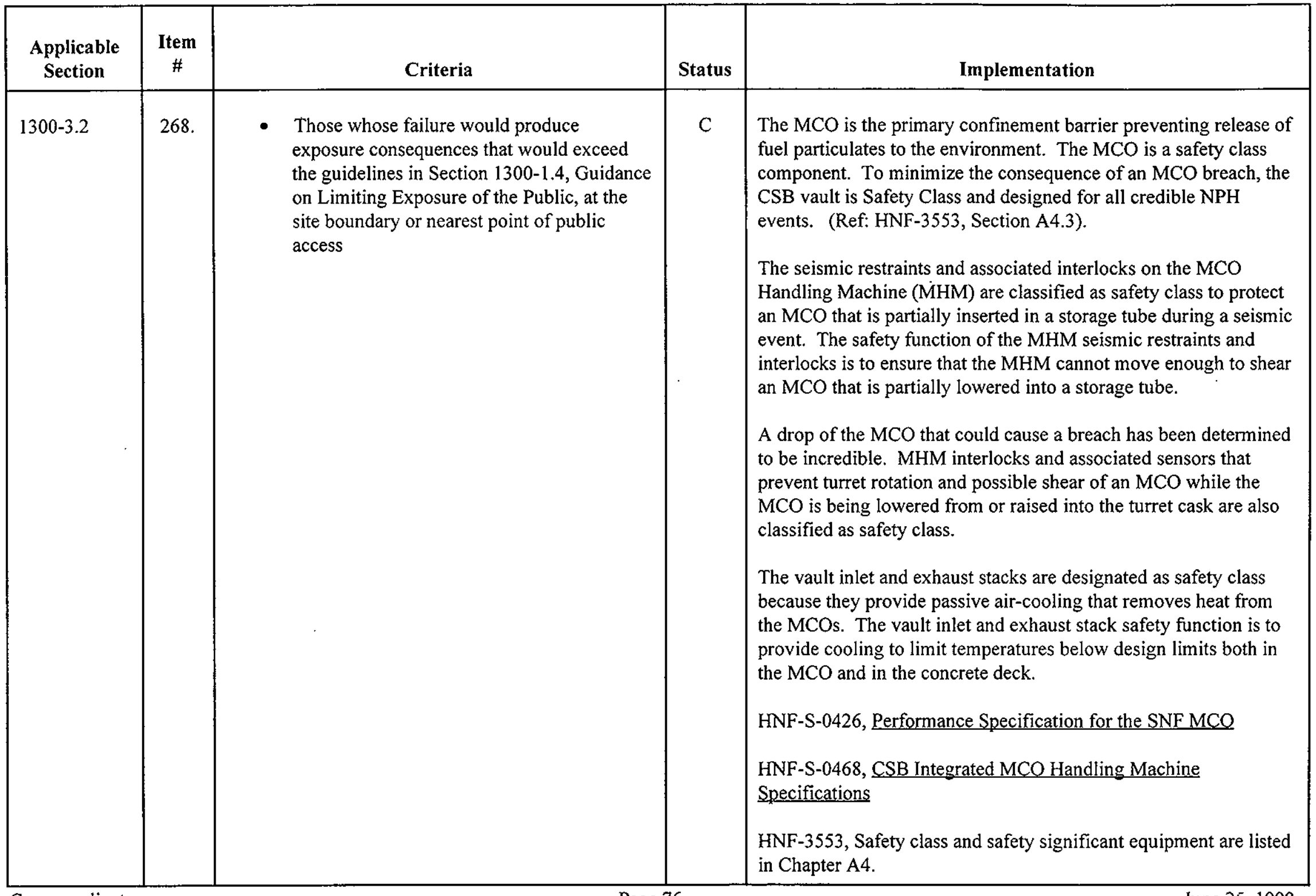




\section{Canister Storage Building Compliance Assessment \\ DOE Order 6430.1A, General Design Criteria}

HNF-4742, Rev. 0

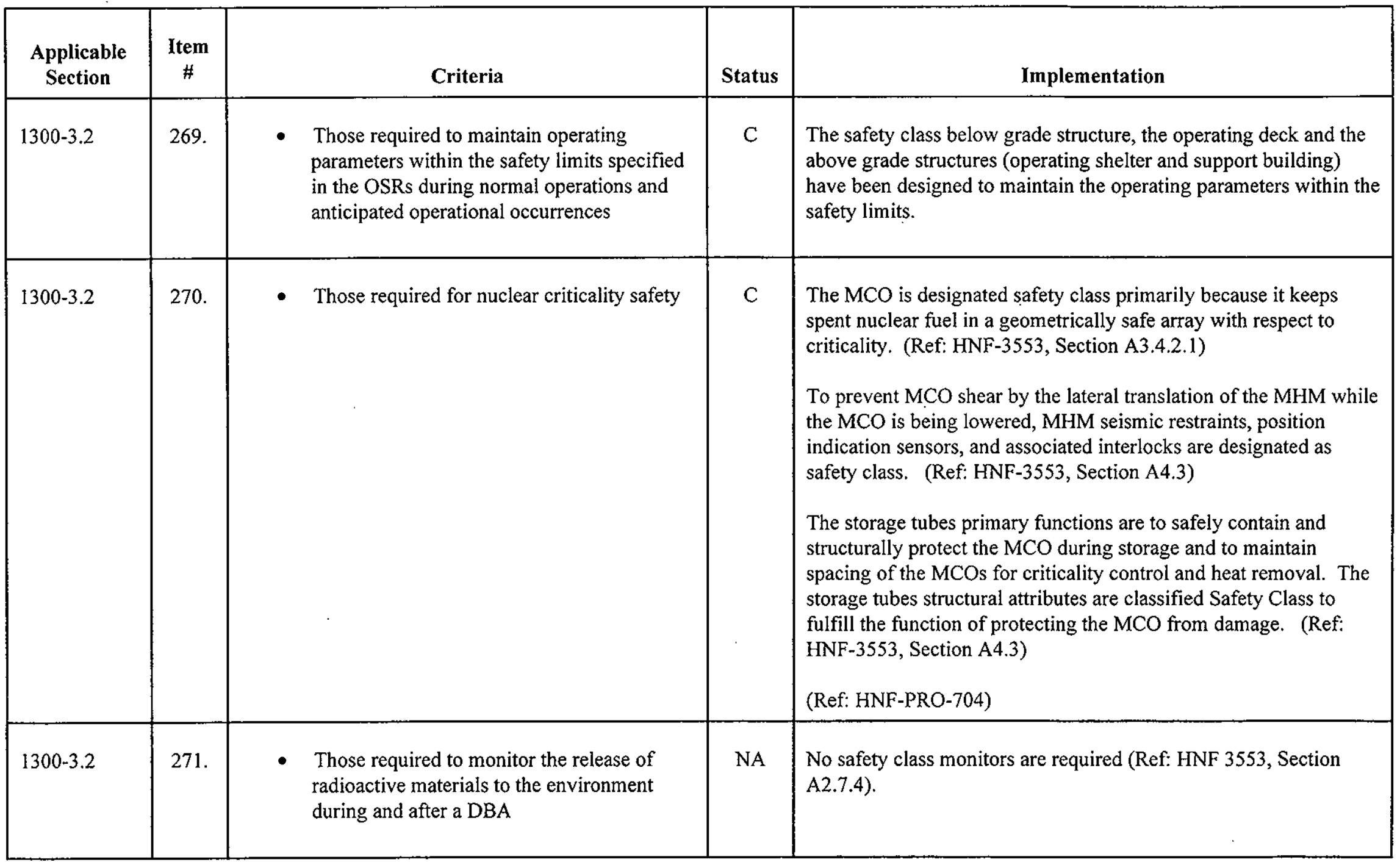


Canister Storage Building Compliance Assessment

HNF-4742, Rev. 0

DOE Order 6430.1A, General Design Criteria

\begin{tabular}{|l|c|c|c|c|}
\hline $\begin{array}{c}\text { Applicable } \\
\text { Section }\end{array}$ & $\begin{array}{c}\text { Item } \\
\text { \# }\end{array}$ & Criteria & Status & Implementation \\
\hline $1300-3.2$ & 272. & $\begin{array}{c}\text { Those required to achieve and maintain the } \\
\text { facility in a safe shutdown condition }\end{array}$ & $\mathrm{C}$ & $\begin{array}{l}\text { The CSB facility and equipment, and the MHM specifically, are } \\
\text { designed to maintain a safe configuration during loss of power. } \\
\text { (Ref: HNF-3553, Section A3.4.2.7.2 and A4.3.14). }\end{array}$ \\
\hline
\end{tabular}




\section{Canister Storage Building Compliance Assessment \\ DOE Order 6430.1A, General Design Criteria}

HNF-4742, Rev. 0

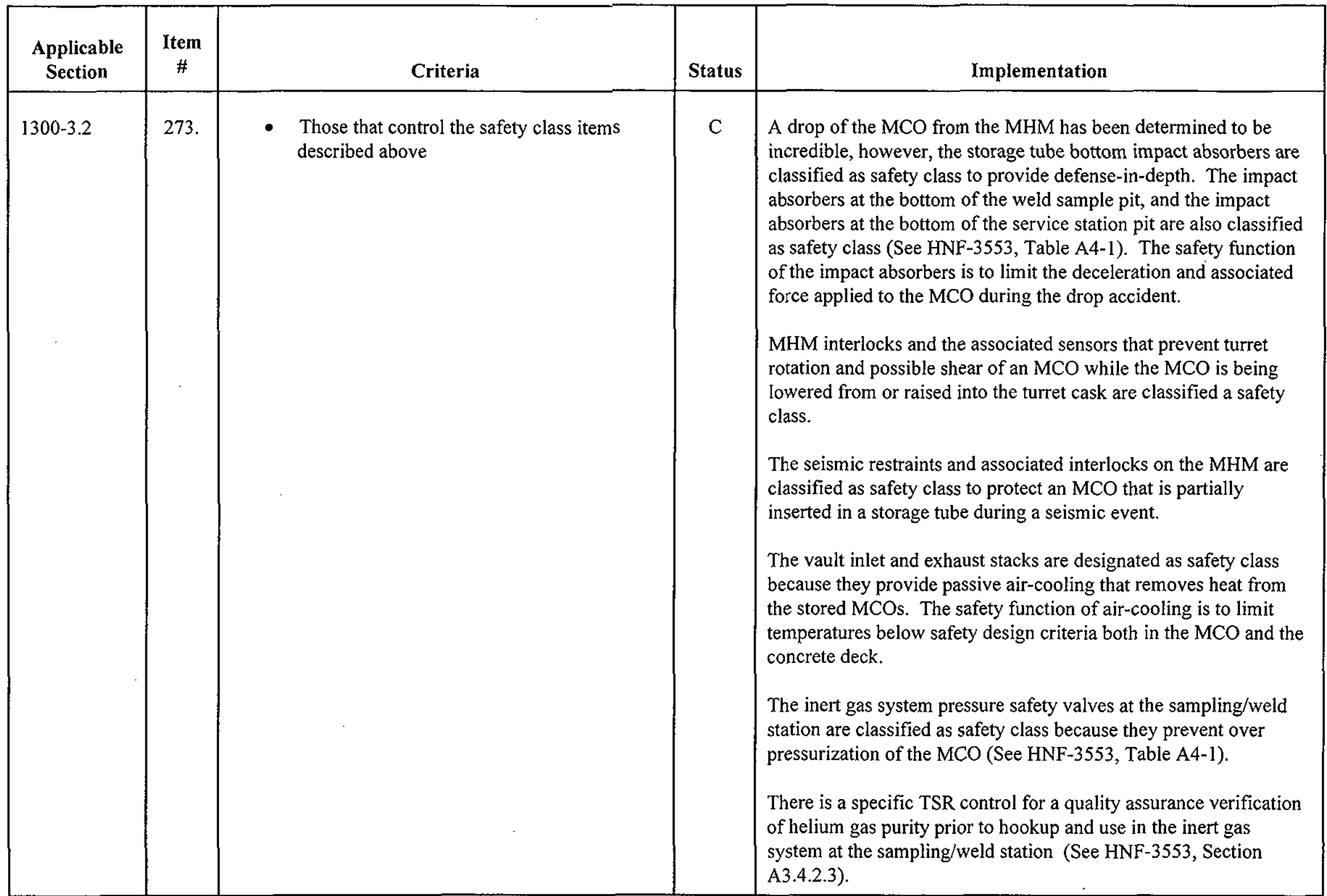




\section{Canister Storage Building Compliance Assessment \\ DOE Order 6430.1A, General Design Criteria}

HNF-4742, Rev. 0

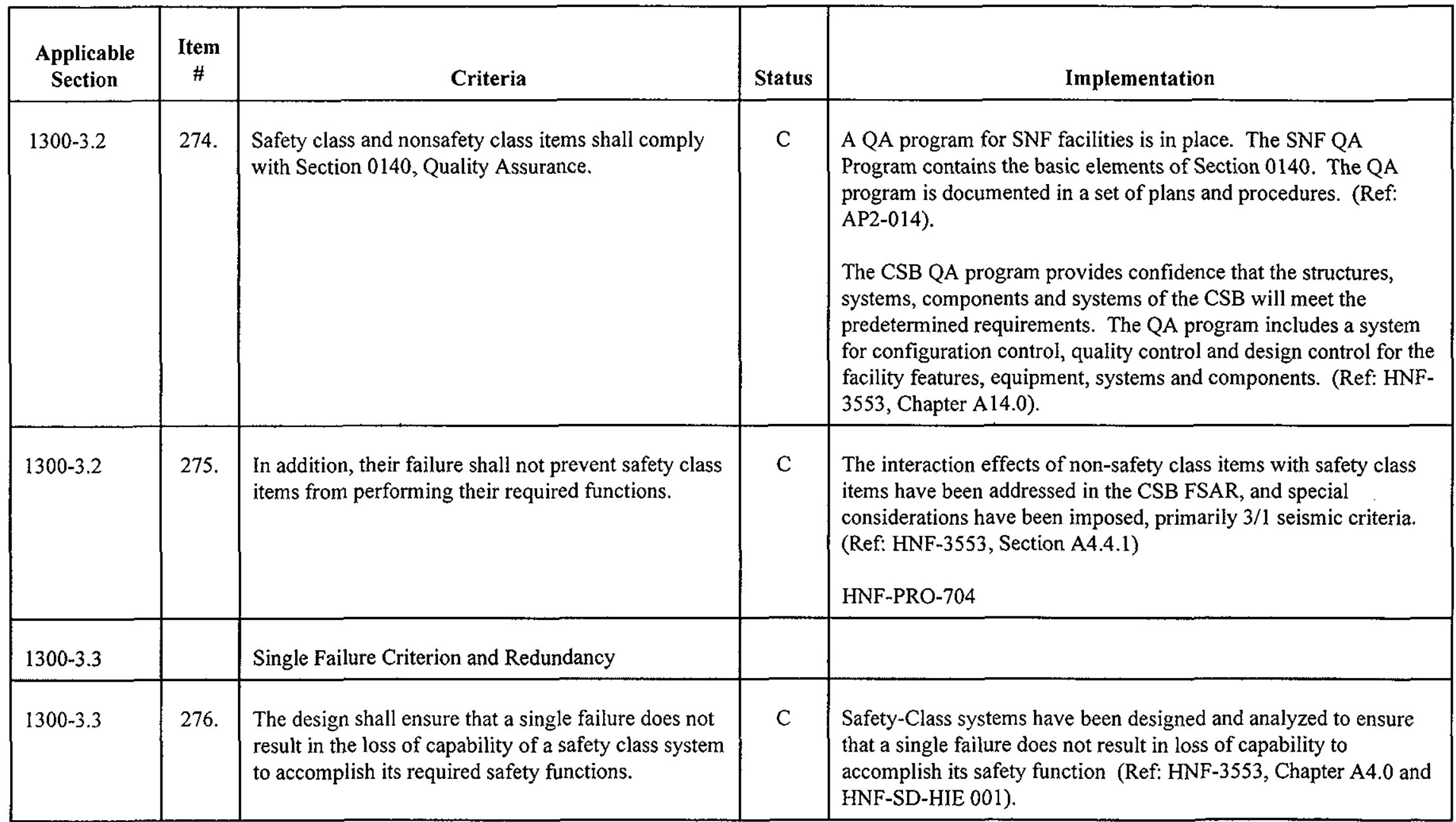




\section{Canister Storage Building Compliance Assessment \\ DOE Order 6430.1A, General Design Criteria}

HNF-4742, Rev. 0

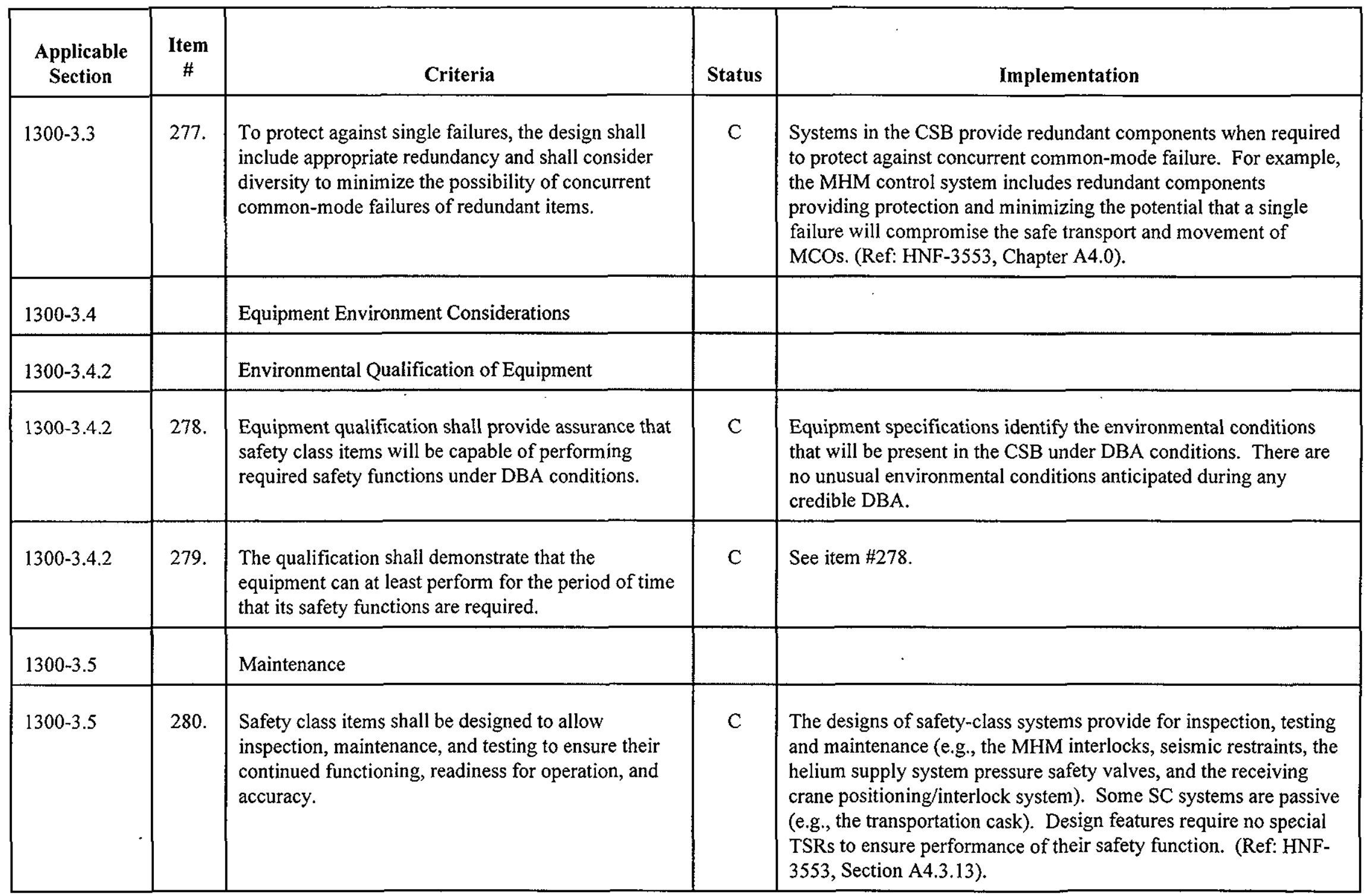




\section{Canister Storage Building Compliance Assessment \\ DOE Order 6430.1A, General Design Criteria}

HNF-4742, Rev. 0

\begin{tabular}{|c|c|c|c|c|}
\hline $1300-3.5$ & 283. & $\begin{array}{l}\text { This capability shall include the necessary provisions } \\
\text { for confinement, ventilation, and waste control. }\end{array}$ & $\mathrm{C}$ & $\begin{array}{l}\text { Provisions for confinement, ventilation, and waste control during } \\
\text { in-place maintenance are developed on a case-by-case basis if } \\
\text { needed. A maintenance pit for the MHM is provided. No other } \\
\text { special design features are required. }\end{array}$ \\
\hline $1300-3.5$ & 284. & $\begin{array}{l}\text { The design of all process equipment shall include } \\
\text { features to minimize self-contamination of the } \\
\text { equipment piping, and confinement areas. }\end{array}$ & C & $\begin{array}{l}\text { The CSB is not a processing facility. However, equipment that is } \\
\text { exposed to the MCO contents is designed to minimize self- } \\
\text { contamination. For example, the Sampling/Weld Station } \\
\text { equipment and the Tube Vent and Purge Cart piping is cleaned of } \\
\text { contaminants by their helium flow back towards the MCO or } \\
\text { overpack tubes. (Ref: HNF-3553, Section A2. 5.1.4) }\end{array}$ \\
\hline $1300-3.5$ & 285. & $\begin{array}{l}\text { The design of process equipment shall also include } \\
\text { features to minimize the spread of contamination out } \\
\text { of local areas. }\end{array}$ & $\mathrm{C}$ & $\begin{array}{l}\text { See \#284. The sampling/weld station is provided with a hood } \\
\text { ventilated through a HEPA filter and a ventilation exhaust system } \\
\text { to minimize potential spread of contamination. (Ref: HNF-3553, } \\
\text { Section A2.6.3) }\end{array}$ \\
\hline
\end{tabular}




\begin{tabular}{|c|c|c|c|c|c|}
\hline 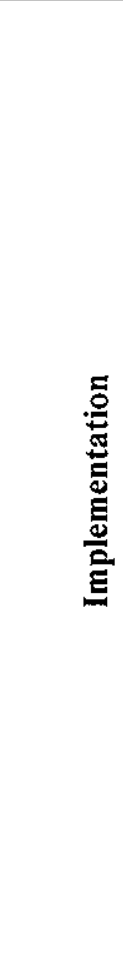 & 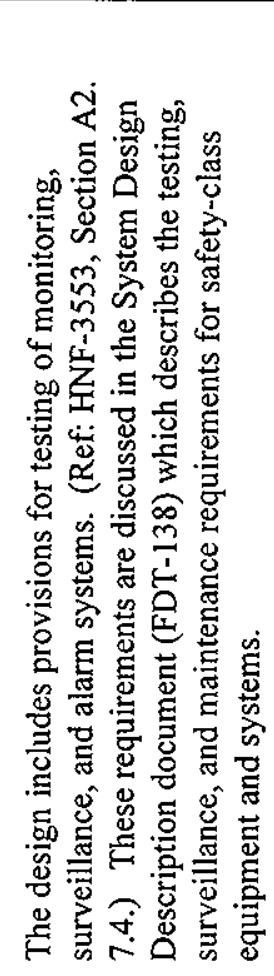 & 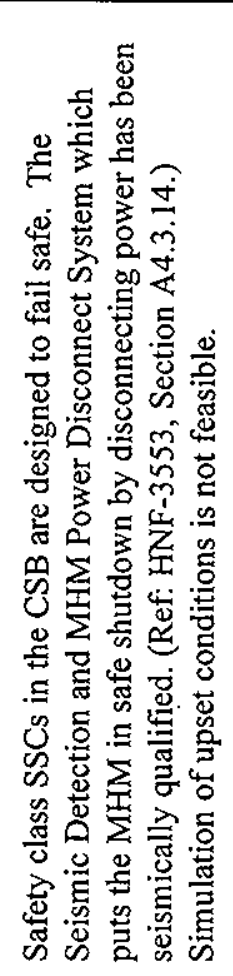 & 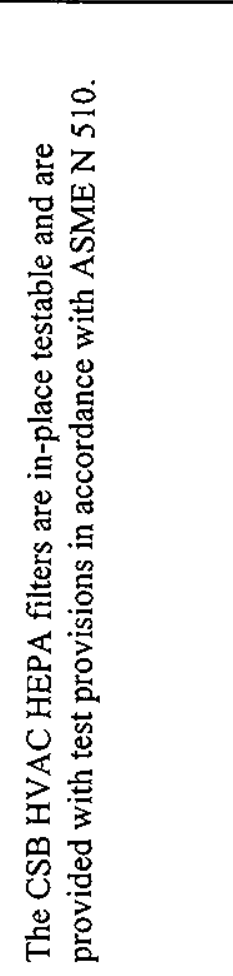 & 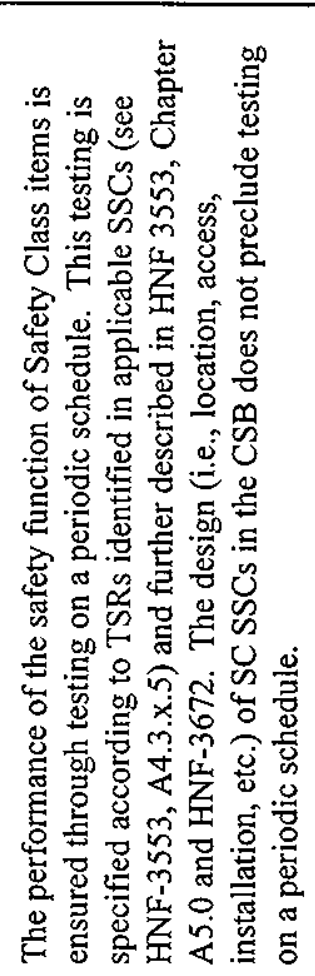 & 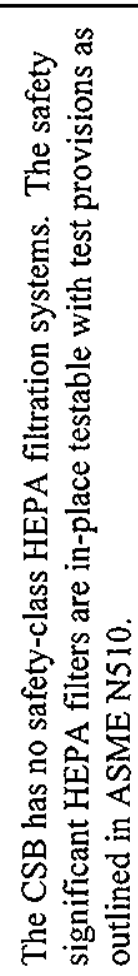 \\
\hline 号 & 0 & $\underset{z}{Z}$ & 0 & 0 & $u$ \\
\hline 递 & 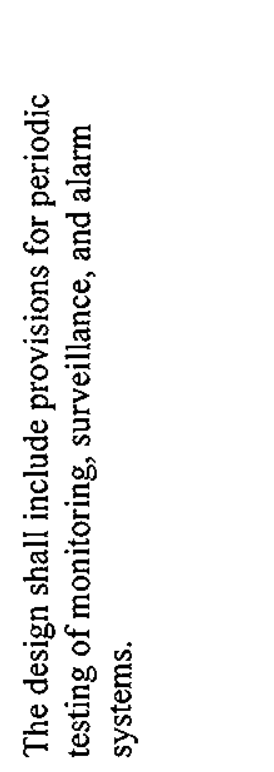 & 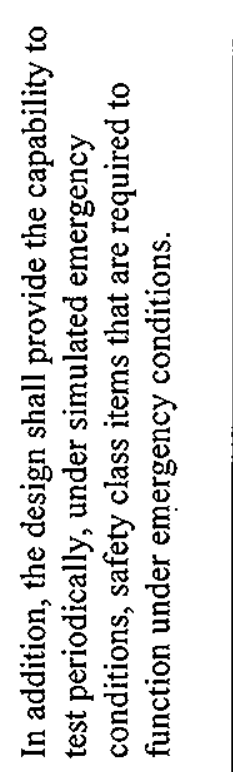 & 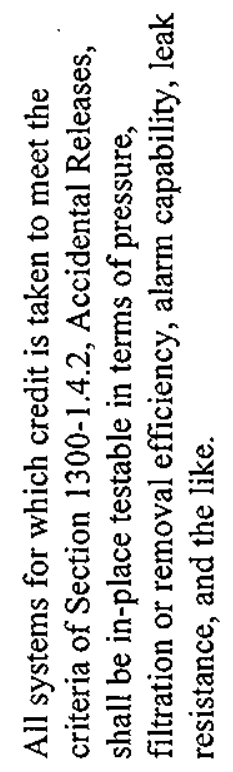 & 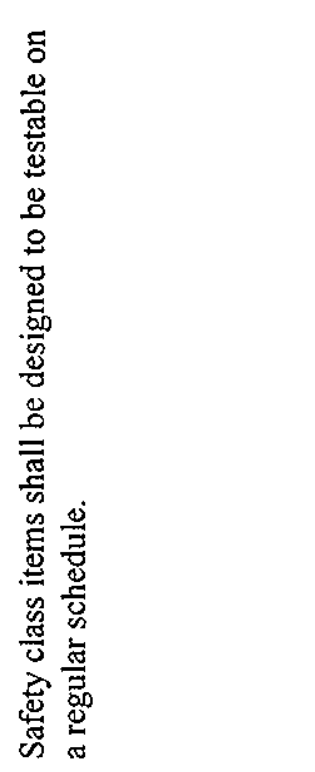 & 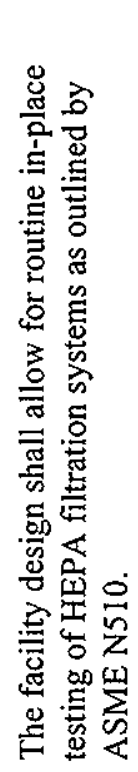 \\
\hline$\stackrel{\text { E्: }}{\Xi}$ & $\stackrel{\dot{0}}{\stackrel{\sim}{N}}$ & $\stackrel{\infty}{\sim}$ & $\underset{\sim}{\infty}$ & 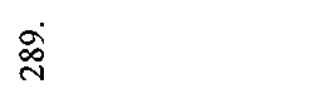 & ஓ̊ \\
\hline 总 & $\begin{array}{l}0 \\
\stackrel{j}{\delta} \\
\stackrel{8}{0}\end{array}$ & 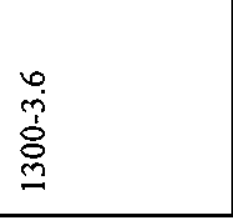 & 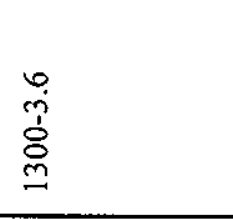 & 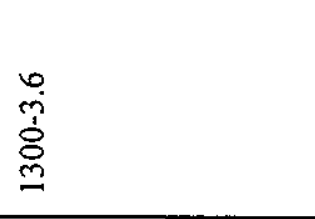 & $\begin{array}{l}0 \\
\stackrel{1}{0} \\
\stackrel{\delta}{8} \\
m\end{array}$ \\
\hline
\end{tabular}




\section{Canister Storage Building Compliance Assessment \\ DOE Order 6430.1A, General Design Criteria}

HNF-4742, Rev. 0

\begin{tabular}{|c|c|c|c|c|}
\hline $\begin{array}{l}\text { Applicable } \\
\text { Section }\end{array}$ & $\begin{array}{l}\text { Item } \\
\#\end{array}$ & Criteria & Status & Implementation \\
\hline $1300-4$ & 291. & $\begin{array}{l}\text { A criticality monitoring and alarm system (gamma } \\
\text { and/or neutron) shall be provided where necessary to } \\
\text { meet the requirements of DOE Order } 5480.5 \text { and } \\
\text { ANS } 8.3 \text {. }\end{array}$ & $\mathrm{C}$ & $\begin{array}{l}\text { There is no need for installation of criticality instrumentation in the } \\
\text { CSB. All situations analyzed in Section } 5.4 \text { of HNF-SD-SNF- } \\
\text { CSER-005, Criticality Safety Evaluation Report for Spent Nuclear } \\
\text { Fuel Processing and Storage Facilities, Rev. } 3 \text {, show that } \mathrm{k}_{\mathrm{eff}} \text { is } \\
\text { less than the criticality safety limit, even for the double } \\
\text { contingency accidents analyzed. (Ref: HNF-3553, Chapter A6.0). } \\
\text { This exclusion of criticality instrumentation is provided for by } \\
\text { ANSU/ANS-8.3-1997 and DOE Order } 5480.24 \text {. }\end{array}$ \\
\hline $1300-4$ & 292. & $\begin{array}{l}\text { When such potential for nuclear criticality exists, the } \\
\text { design of nuclear criticality control provisions, } \\
\text { including equipment and procedures, shall meet, as a } \\
\text { minimum, the requirements of DOE Order } 5480.5 \\
\text { and the ANS } 8 \text { series on Nuclear Criticality Safety. }\end{array}$ & NA & $\begin{array}{l}\text { The MCO and storage tube design precludes criticality in the CSB. } \\
\text { See } \# 291 \text {. }\end{array}$ \\
\hline $1300-4$ & 293. & $\begin{array}{l}\text { The design shall ensure that material shall not be } \\
\text { displaced or allowed to accumulate to form a critical } \\
\text { mass in the event of an internal or external accident. }\end{array}$ & $\mathrm{C}$ & $\begin{array}{l}\text { All situations analyzed in Section } 5.4 \text { of HNF-SD-SNF-CSER-005, } \\
\text { Criticality Safety Evaluation Report for Spent Nuclear Fuel } \\
\text { Processing and Storage Facilities, Rev. } 3 \text {, show that } \mathrm{k}_{\text {eff }} \text { is less } \\
\text { than the criticality safety limit, even for the double contingency } \\
\text { accidents analyzed. (Ref: HNF- } 3553 \text {, Chapter A6.0). The design } \\
\text { of the transportation cask, the MHM interlocks, and the storage } \\
\text { tubes are all designated safety-class due to ensuring the MCO's } \\
\text { geometric criticality control features are not damaged. }\end{array}$ \\
\hline
\end{tabular}




\section{Canister Storage Building Compliance Assessment DOE Order 6430.1A, General Design Criteria}

HNF-4742, Rev. 0

\begin{tabular}{|c|c|c|c|c|}
\hline $\begin{array}{l}\text { Applicable } \\
\text { Section }\end{array}$ & $\begin{array}{c}\text { Item } \\
\#\end{array}$ & Criteria & Status & Implementation \\
\hline $1300-4$ & 295. & $\begin{array}{l}\text { Also, heating or cooling jackets in the safe dimension } \\
\text { of geometrically safe vessels shall preclude a leak in } \\
\text { the jacket that causes an increase in the system's } \\
\text { reactivity. }\end{array}$ & NA & $\begin{array}{l}\text { There are no heating or cooling jackets in the CSB that can } \\
\text { increase the reactivity of the MCO. }\end{array}$ \\
\hline $1300-4$ & 296. & $\begin{array}{l}\text { Process designs shall incorporate sufficient factors of } \\
\text { safety so that at least two unlikely and independent } \\
\text { concurrent changes must occur in process conditions } \\
\text { before a criticality accident is possible. }\end{array}$ & $\mathrm{C}$ & $\begin{array}{l}\text { All situations analyzed in Section } 5.4 \text { of HNF-SD-SNF-CSER-005, } \\
\text { Criticality Safety Evaluation Report for Spent Nuclear Fuel } \\
\text { Processing and Storage Facilities, Rev. } 3 \text {, show that } \mathrm{k}_{\mathrm{eff}} \text { is less } \\
\text { than the criticality safety limit, even for the double contingency } \\
\text { accidents analyzed. }\end{array}$ \\
\hline $1300-4$ & 297. & $\begin{array}{l}\text { Structures, systems, and components that provide } \\
\text { nuclear criticality safety shall be designed as safety } \\
\text { class systems and be capable of performing their } \\
\text { criticality safety functions during and following } \\
\text { design basis accidents and events. }\end{array}$ & C & $\begin{array}{l}\text { The design of the MHM interlocks and the storage tubes are all } \\
\text { designated safety-class due to ensuring the MCO's geometric } \\
\text { criticality control features are not damaged in the event of a DBA. }\end{array}$ \\
\hline $1300-4$ & 298. & $\begin{array}{l}\text { Nuclear criticality safety shall be controlled, in } \\
\text { decreasing priority, by geometric spacing, density } \\
\text { and/or mass limitation, fixed neutron absorber, } \\
\text { soluble neutron absorber, and administrative } \\
\text { controls. }\end{array}$ & C & $\begin{array}{l}\text { Nuclear criticality safety is controlled by the design of the MCO, } \\
\text { geometric spacing of the MCO storage positions in the CSB vault, } \\
\text { integrity of the MCO internals, and mass limitation on the SNF } \\
\text { stored in the MCO. (Ref: HNF-SD-SNF-CSER-005). }\end{array}$ \\
\hline
\end{tabular}




\section{Canister Storage Building Compliance Assessment \\ DOE Order 6430.1A, General Design Criteria}

HNF-4742, Rev, 0

\begin{tabular}{|c|c|c|c|c|}
\hline $\begin{array}{l}\text { Applicable } \\
\text { Section }\end{array}$ & $\begin{array}{c}\text { Item } \\
\#\end{array}$ & Criteria & Status & Implementation \\
\hline $1300-4$ & 302. & $\begin{array}{l}\text { Locations where a potential critical mass could occur } \\
\text { in the event of accidental flooding by water from fire } \\
\text { protection systems shall be protected by } \\
\text { geometrically favorable curbed areas or collection } \\
\text { systems. }\end{array}$ & $\mathrm{C}$ & $\begin{array}{l}\text { The design of the } \mathrm{MCO} \text { and the storage tubes preclude criticality in } \\
\text { the CSB. Water is not allowed in the operations area and any } \\
\text { water from fire protection sprinkler system operation in the support } \\
\text { area is prevented from entering the operations area.(Ref: HNF- } \\
3553 \text {, Section A2.7.1) }\end{array}$ \\
\hline
\end{tabular}




\section{Canister Storage Building Compliance Assessment \\ DOE Order 6430.1A, General Design Criteria}

HNF-4742, Rev. 0

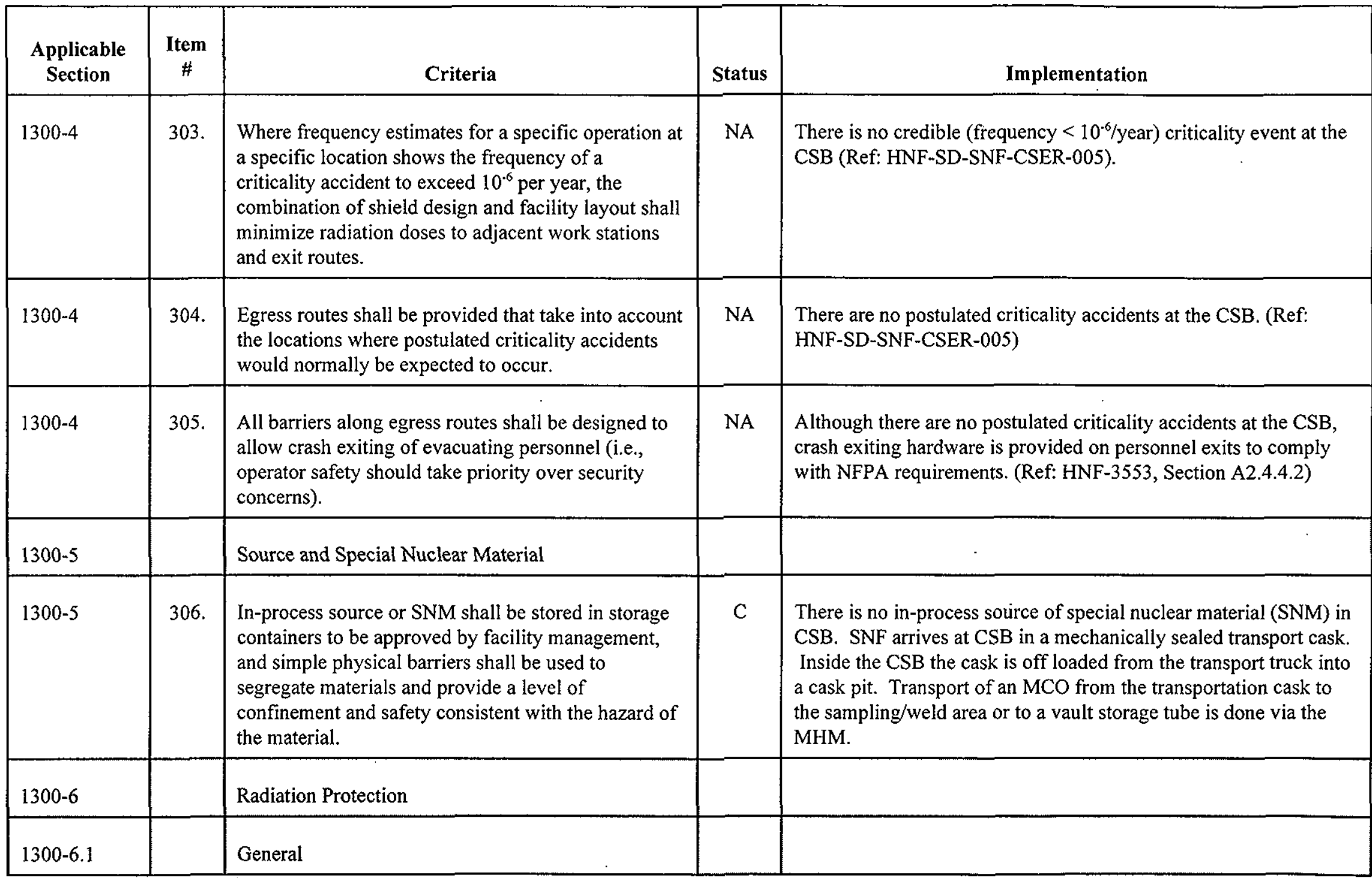




\section{Canister Storage Building Compliance Assessment \\ DOE Order 6430.1A, General Design Criteria}

HNF-4742, Rev. 0

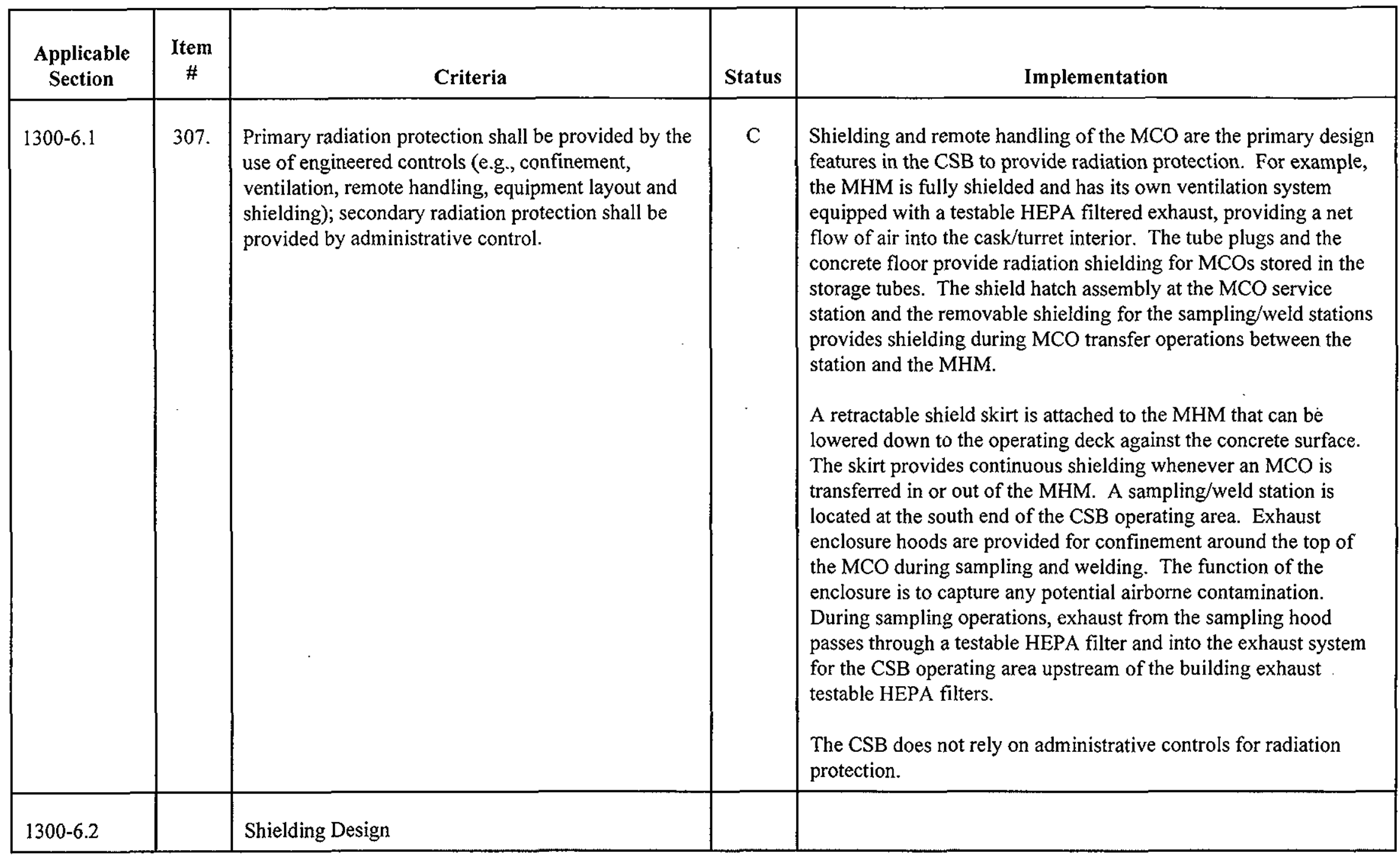




\section{Canister Storage Building Compliance Assessment DOE Order 6430.1A, General Design Criteria}

\begin{tabular}{|c|c|c|c|c|}
\hline $\begin{array}{l}\text { Applicable } \\
\text { Section }\end{array}$ & $\begin{array}{c}\text { Item } \\
\#\end{array}$ & Criteria & Status & Implementation \\
\hline $1300-6.2$ & 309. & $\begin{array}{l}\text { Straight-line penetration of shield walls shall be } \\
\text { avoided to prevent radiation streaming. }\end{array}$ & $\mathrm{C}$ & $\begin{array}{l}\text { Shielding walls in the CSB do not contain straight-line } \\
\text { penetrations. Primary shielding walls are the operations area floor } \\
\text { (over the vault) and the storage tube plugs. The sealing sides of } \\
\text { the plugs are angled. The vent from the tube to the CSB operating } \\
\text { area contains no straight-line paths. There are no straight-line } \\
\text { paths for cooling air inlet or outlet to and from the vault. (Ref: } \\
\text { HNF-3553, Section A2.4) }\end{array}$ \\
\hline $1300-6.2$ & 311. & $\begin{array}{l}\text { Within this design basis, personnel exposures shall } \\
\text { be maintained ALARA. }\end{array}$ & C & $\begin{array}{l}\text { Table 3-1 (mentioned in Item } 310 \text { ) applies in conjunction with an } \\
\text { ALARA analysis. No personnel access to the vault storage tube } \\
\text { area is allowed, nor is it possible except during construction when } \\
\text { the vault contains no fuel. ALARA studies have been performed } \\
\text { to assess all exposures associated with CSB operations (Ref: SNF } \\
\text { Canister Storage Building ALARA Analysis 09). }\end{array}$ \\
\hline
\end{tabular}




\section{Canister Storage Building Compliance Assessment \\ DOE Order 6430.1A, General Design Criteria}

HNF-4742, Rev. 0

\begin{tabular}{|c|c|c|c|c|}
\hline $1300-6.2$ & 314. & $\begin{array}{l}\text { Shielding and other radiation protection measures } \\
\text { shall be provided for areas requiring intermittent } \\
\text { access, such as for preventive maintenance, } \\
\text { component changes, adjustment of systems and } \\
\text { equipment, and so forth. }\end{array}$ & $\mathrm{C}$ & $\begin{array}{l}\text { A maintenance pit is provided for the MHM. The MHM Radiation } \\
\text { Protection Interlock System protects the facility worker from } \\
\text { inadvertent high doses of radiation while working inside the MHM } \\
\text { cask. (Ref: HNF-3553, Section A4.4.12) }\end{array}$ \\
\hline $1300-6.3$ & 315. & $\begin{array}{l}\text { Remote shielded operation (i.e., with remote } \\
\text { handling equipment such as remote manipulators) } \\
\text { shall be considered where it is anticipated that } \\
\text { exposures to hands and forearms would otherwise } \\
\text { approach the dose guidance in } 5480.11 \text { or where } \\
\text { contaminated puncture wounds could occur. }\end{array}$ & $\mathrm{C}$ & $\begin{array}{l}\text { Places where operators come in close proximity to MCOs are at the } \\
\text { service station pit, where cask fasteners must be removed in order } \\
\text { to remove the MCO from the Transport Cask, and at the } \\
\text { sampling/weld station where the operator must make sampling } \\
\text { connections and set up weld heads. In each case, the CSB design } \\
\text { includes shielding that, in conjunction with the MCO shield plug, } \\
\text { protects workers from exposure to hands and forearms. Extremity } \\
\text { dose rates are within the guidelines of } 10 \text { CFR } 835 \text {, which replaced } \\
\text { DOE } 5480.11 \text {. There is a low likely hood of loose contamination } \\
\text { on these components. Standard industrial PPE will protect against } \\
\text { puncture wounds during hands-on operations. (Ref: SNF Canister } \\
\text { Storage Building ALARA Analysis 09) }\end{array}$ \\
\hline
\end{tabular}




\section{Canister Storage Building Compliance Assessment \\ DOE Order 6430.1A, General Design Criteria}

HNF-4742, Rev. 0

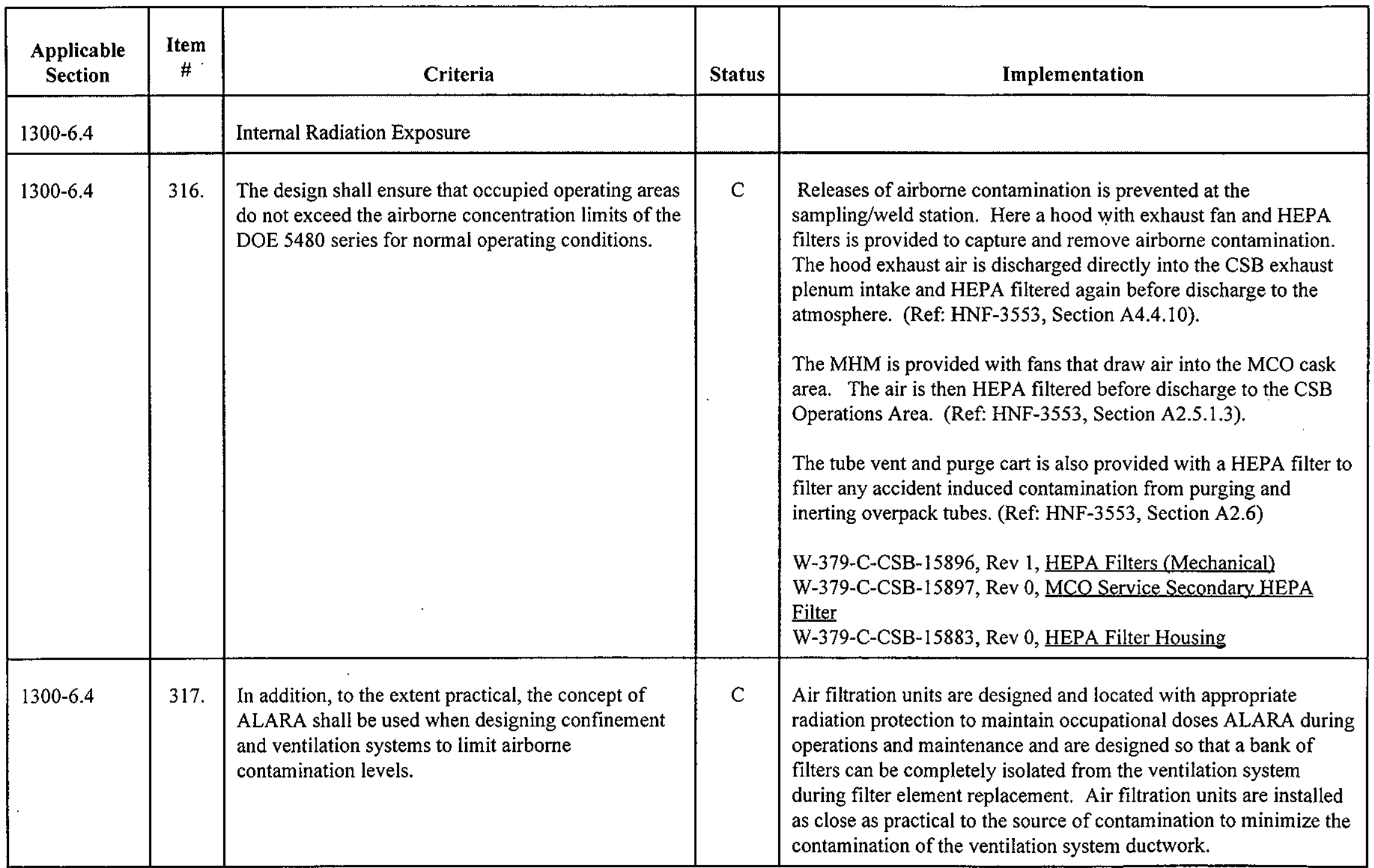




\section{Canister Storage Building Compliance Assessment \\ DOE Order 6430.1A, General Design Criteria}

HNF-4742, Rev. 0

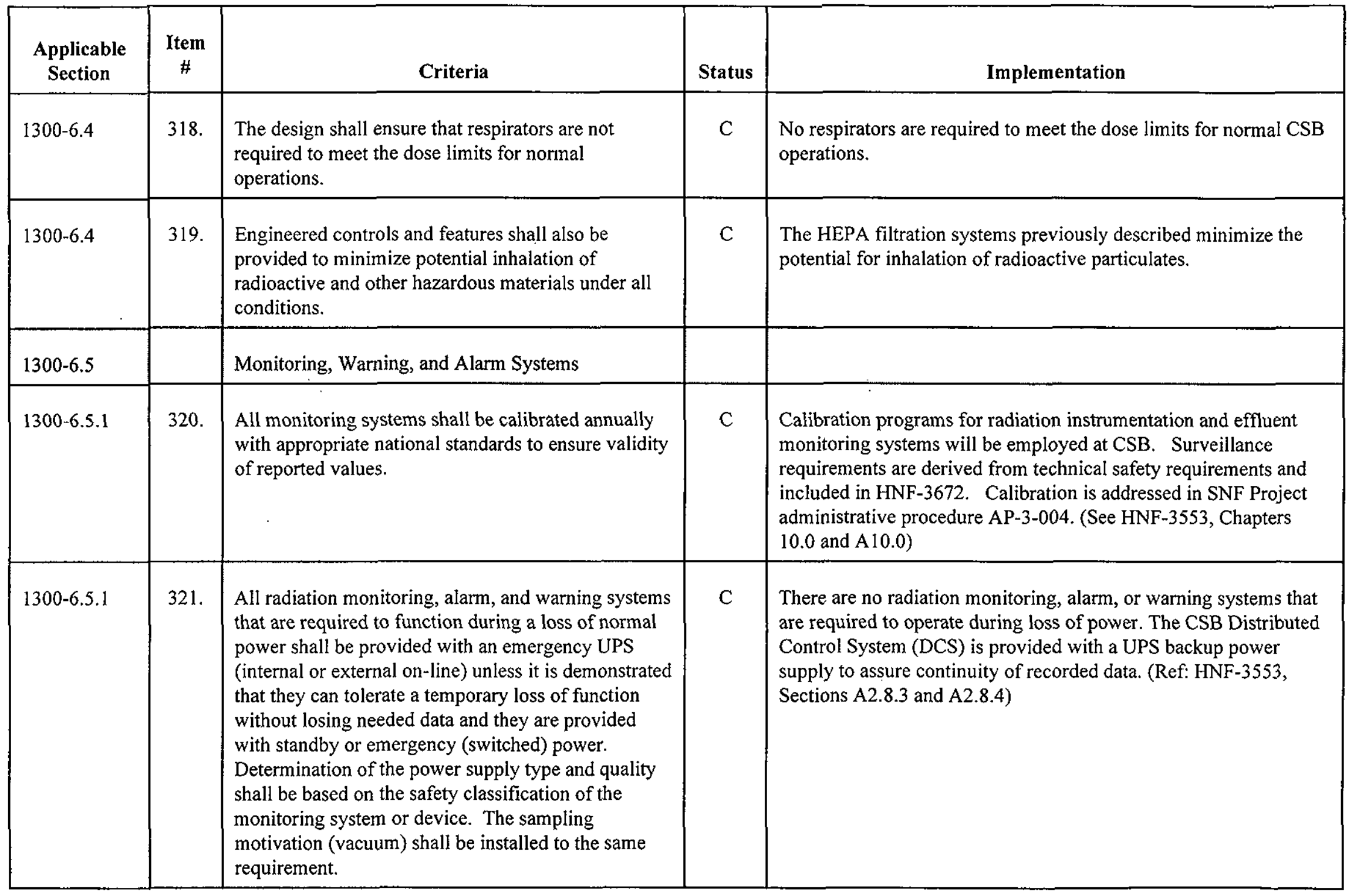




\section{Canister Storage Building Compliance Assessment \\ DOE Order 6430.1A, General Design Criteria}

HNF-4742, Rev. 0

\begin{tabular}{|c|c|c|c|c|}
\hline $\begin{array}{l}\text { Applicable } \\
\text { Section }\end{array}$ & $\begin{array}{c}\text { Item } \\
\#\end{array}$ & Criteria & Status & Implementation \\
\hline $1300-6.5 .2$ & 322. & $\begin{array}{l}\text { Air monitoring and warning systems shall be } \\
\text { installed in work areas where hazardous materials are } \\
\text { stored or handled and where hazardous airborne } \\
\text { particles or vapors may be present. }\end{array}$ & NA & $\begin{array}{l}\text { There are no hazardous materials stored or handled within the CSB } \\
\text { and there are no air monitoring and warning systems required in } \\
\text { work areas where hazardous airborne particles or vapors may be } \\
\text { present. Relatively small amounts of propylene glycol, lubricants, } \\
\text { and weld test materials are present while in use and do not pose } \\
\text { unreasonable risks to the workers. (Ref: Notice of Construction, } \\
\text { DOE/RL-98-30) }\end{array}$ \\
\hline $1300-6.5 .2$ & 323. & $\begin{array}{l}\text { Air sampling heads shall be located to provide a } \\
\text { representative sample of potential airborne } \\
\text { radioactive materials being breathed. }\end{array}$ & $\mathrm{C}$ & $\begin{array}{l}\text { Locations for air sampling heads have been determined by } \\
\text { radiological monitoring experts considering the particular } \\
\text { operations involved. Air flow rates for the CSB operations area are } \\
\sim 1.5 \text { air changes per hour. }\end{array}$ \\
\hline $1300-6.5 .3$ & & Personnel Monitoring and Warning Devices & & \\
\hline
\end{tabular}




\section{Canister Storage Building Compliance Assessment \\ DOE Order 6430.1A, General Design Criteria}

HNF-4742, Rev. 0

\begin{tabular}{|c|c|c|c|c|}
\hline $\begin{array}{l}\text { Applicable } \\
\text { Section }\end{array}$ & $\begin{array}{l}\text { Item } \\
\#\end{array}$ & Criteria & Status & Implementation \\
\hline $1300-6.5 .3$ & 326. & $\begin{array}{l}\text { CAMs shall be provided to detect and to alarm at } \\
\text { prescribed airborne radioactivity levels. }\end{array}$ & $\mathrm{C}$ & $\begin{array}{l}\text { There are nine beta continuous air monitors (CAMs) in the CSB } \\
\text { Health Protection System, including one mounted on the MHM, } \\
\text { and one used in the Mobile Containment Service Tent. Two of the } \\
\text { beta CAMs connect to the Distributed Control System. Beta } \\
\text { CAMs are located in occupied areas with a high potential for } \\
\text { airborne contamination such as the Count room, Maintenance area, } \\
\text { and HVAC equipment areas. There is also a portable beta CAM, } \\
\text { which will be used only when extra coverage is necessary. (Ref: H- } \\
\text { 2-121101 Sheets 2, 3, 4, and 6). There are six alpha CAMs, one } \\
\text { mounted on the MHM, and one used in the Mobile Containment } \\
\text { Service Tent. None of the alpha CAMs are connected to the } \\
\text { Distributed Control System. There is one portable alpha CAM, } \\
\text { which will be used only when extra coverage is necessary.(Ref: H- } \\
2-121101 \text { Sheet } 8 \text { ). There is one Continuous Airborne Effluent } \\
\text { Monitor (CAEM) in the CSB Health Protection System, located in } \\
\text { the CAEM room (room 016), and connected to the Distributed } \\
\text { Control System. The CAEM monitors HVAC exhaust airflow for } \\
\text { radioactive and chemical contamination.(Ref: H-2-129586 Sheet } 1 \text { ) } \\
\text { There is one lodine Monitor which checks HVAC exhaust airflow } \\
\text { for the presence of I-129. (Ref: HNF-3553, Section A2.7.3) }\end{array}$ \\
\hline
\end{tabular}




\section{Canister Storage Building Compliance Assessment \\ DOE Order 6430.1A, General Design Criteria}

HNF-4742, Rev. 0

\begin{tabular}{|c|c|c|c|c|}
\hline $\begin{array}{l}\text { Applicable } \\
\text { Section }\end{array}$ & $\begin{array}{l}\text { Item } \\
\#\end{array}$ & Criteria & Status & Implementation \\
\hline $1300-6.5 .4$ & 327. & $\begin{array}{l}\text { Where ionizing radiation is present (due to process } \\
\text { material, equipment, or operations), an area radiation } \\
\text { monitoring system shall be provided to alert } \\
\text { personnel of unexpected increases in ionizing } \\
\text { radiation levels. }\end{array}$ & $\mathrm{C}$ & $\begin{array}{l}\text { There are } 23 \text { Area Radiation Monitors (ARMs) located throughout } \\
\text { the CSB. ARMs connect to the Distributed Control System } \\
\text { through a Remote Terminal Unit. There are three portable ARMs } \\
\text { which will be used only when extra coverage is necessary. (Ref: } \\
\text { HNF-3553, Section A2.7.3 and H-2-121101 Sheets } 2,3 \text {, and } 6 \text { ) }\end{array}$ \\
\hline $1300-6.5 .5$ & & Warning and Alarm Systems Features & & \\
\hline $1300-6.5 .5$ & 328. & $\begin{array}{l}\text { Warning and alarm systems shall be designed, } \\
\text { installed, and tested to ensure that they can be heard } \\
\text { in the ambient conditions of the area they are } \\
\text { intended to cover. }\end{array}$ & $\mathrm{C}$ & $\begin{array}{l}\text { Hand and Foot monitors, ARMs, alpha CAMs, beta CAMs, } \\
\text { Radioactive Gas Monitors, and the Continuous Airborne Effluent } \\
\text { Monitor are all equipped with both audible and visual alarms. } \\
\text { Each instrument is designed to be adjusted, or reset by authorized } \\
\text { personnel without removing the instrument from service. The } \\
\text { alarms will be tested periodically. (Ref: HNF-3553, Section } \\
\text { A2.7.3) }\end{array}$ \\
\hline $1300-6.5 .5$ & 329. & $\begin{array}{l}\text { Evacuation alarm systems shall comply with ANSI } \\
\text { N2.3. }\end{array}$ & $\mathrm{C}$ & $\begin{array}{l}\text { The evacuation alarm complies with ANSI N2.3 and is sounded } \\
\text { through public address system speakers. It is possible to activate } \\
\text { the evacuation alarm from the central control room and from the } \\
\text { emergency control station. (Ref: HNF-3553, Section A2.9.1) }\end{array}$ \\
\hline $1300-6.5 .6$ & & Nuclear Accident Dosimetry & & - \\
\hline
\end{tabular}




\section{Canister Storage Building Compliance Assessment \\ DOE Order 6430.1A, General Design Criteria}

HNF-4742, Rev. 0

\begin{tabular}{|c|c|c|c|c|}
\hline $\begin{array}{l}\text { Applicable } \\
\text { Section }\end{array}$ & $\begin{array}{l}\text { Item } \\
\#\end{array}$ & Criteria & Status & Implementation \\
\hline $1300-6.5 .7$ & & Central Radiation Monitoring and Alarm Readout & & \\
\hline $1300-6.5 .7$ & 331. & $\begin{array}{l}\text { In addition to a local station alarm, radiation } \\
\text { monitoring system (criticality alarms, CAMSs, } \\
\text { alarms associated with stack monitoring systems, and } \\
\text { so on) shall have central (i.e., control room or } \\
\text { radiation monitoring office) readout and alarm panels } \\
\text { that are accessible after a DBA to evaluate internal } \\
\text { conditions. }\end{array}$ & $\mathrm{C}$ & $\begin{array}{l}\text { The control room contains a central monitoring system and alarm } \\
\text { panels to warn plant personnel of hazardous radioactive conditions } \\
\text { that may occur as a result of a DBA. (Ref: HNF-3553, Section } \\
\text { A2.4.4.3) }\end{array}$ \\
\hline $1300-6.6$ & & Decontamination of Personnel & & \\
\hline $1300-6.6$ & 332. & $\begin{array}{l}\text { Design shall provide for personnel decontamination } \\
\text { facilities close to areas that represent sources of } \\
\text { potential contamination. }\end{array}$ & $\mathrm{C}$ & See response to item $\# 333$ below. \\
\hline $1300-6.8$ & & Change Rooms & & \\
\hline
\end{tabular}




\section{Canister Storage Building Compliance Assessment \\ DOE Order 6430.1A, General Design Criteria}

HNF-4742, Rev. 0

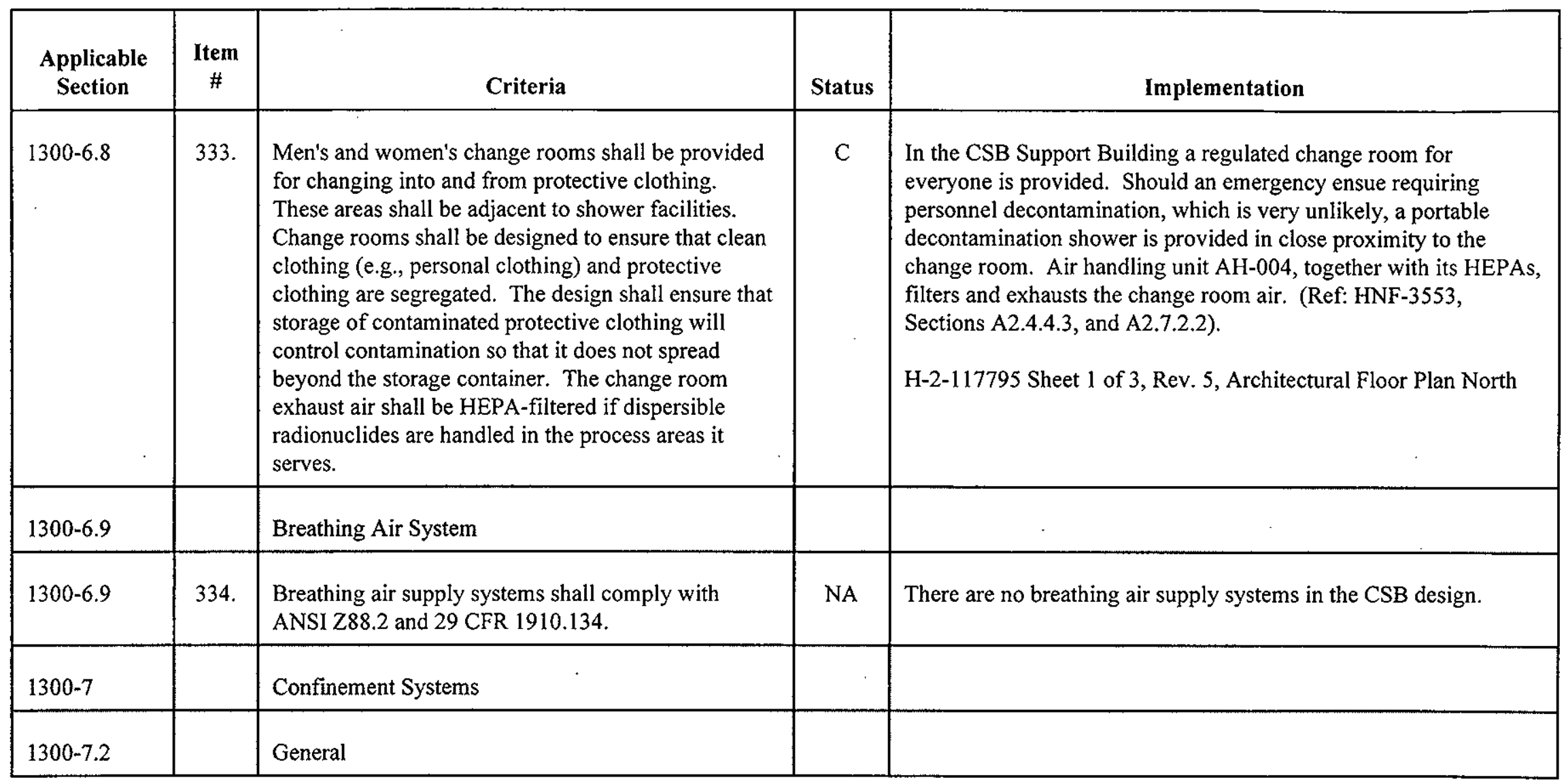




\section{Canister Storage Building Compliance Assessment \\ DOE Order 6430.1A, General Design Criteria}

HNF-4742, Rev. 0

\begin{tabular}{|c|c|c|c|c|}
\hline $\begin{array}{l}\text { Applicable } \\
\text { Section }\end{array}$ & $\begin{array}{c}\text { Item } \\
\#\end{array}$ & Criteria & Status & Implementation \\
\hline $1300-7.2$ & 337. & $\begin{array}{l}\text { The adequacy of the design of these confinement } \\
\text { systems to effectively perform their required } \\
\text { functions shall be demonstrated by the safety } \\
\text { analysis. }\end{array}$ & $\mathrm{C}$ & $\begin{array}{l}\text { The safety analysis document establishes the adequacy of } \\
\text { confinement system design. (Ref: HNF-3553, Section A2.6 and } \\
\text { A3.4.2). }\end{array}$ \\
\hline
\end{tabular}




\section{Canister Storage Building Compliance Assessment \\ DOE Order 6430.1A, General Design Criteria}

HNF-4742, Rev. 0

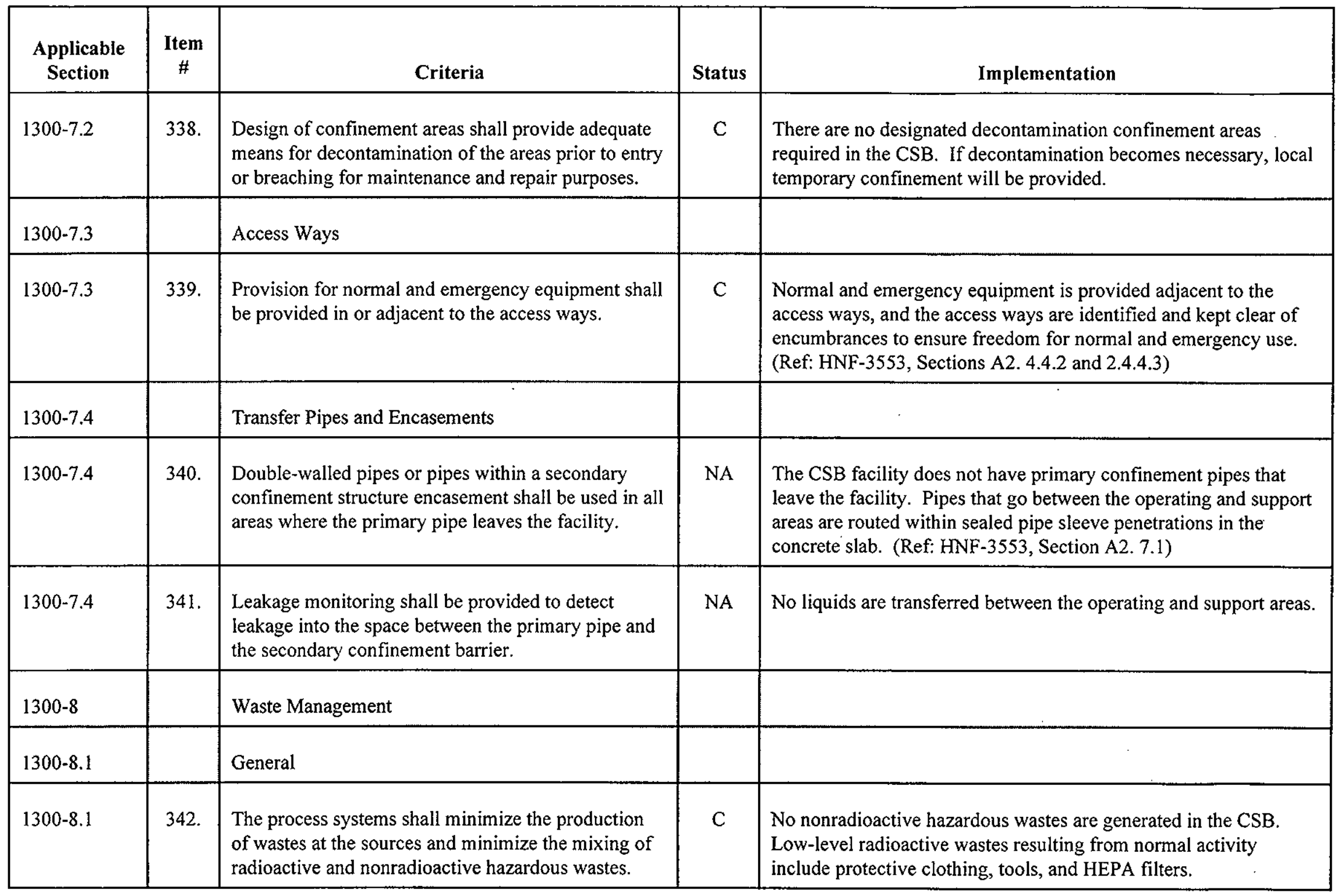




\section{Canister Storage Building Compliance Assessment DOE Order 6430.1A, General Design Criteria}

HNF-4742, Rev. 0

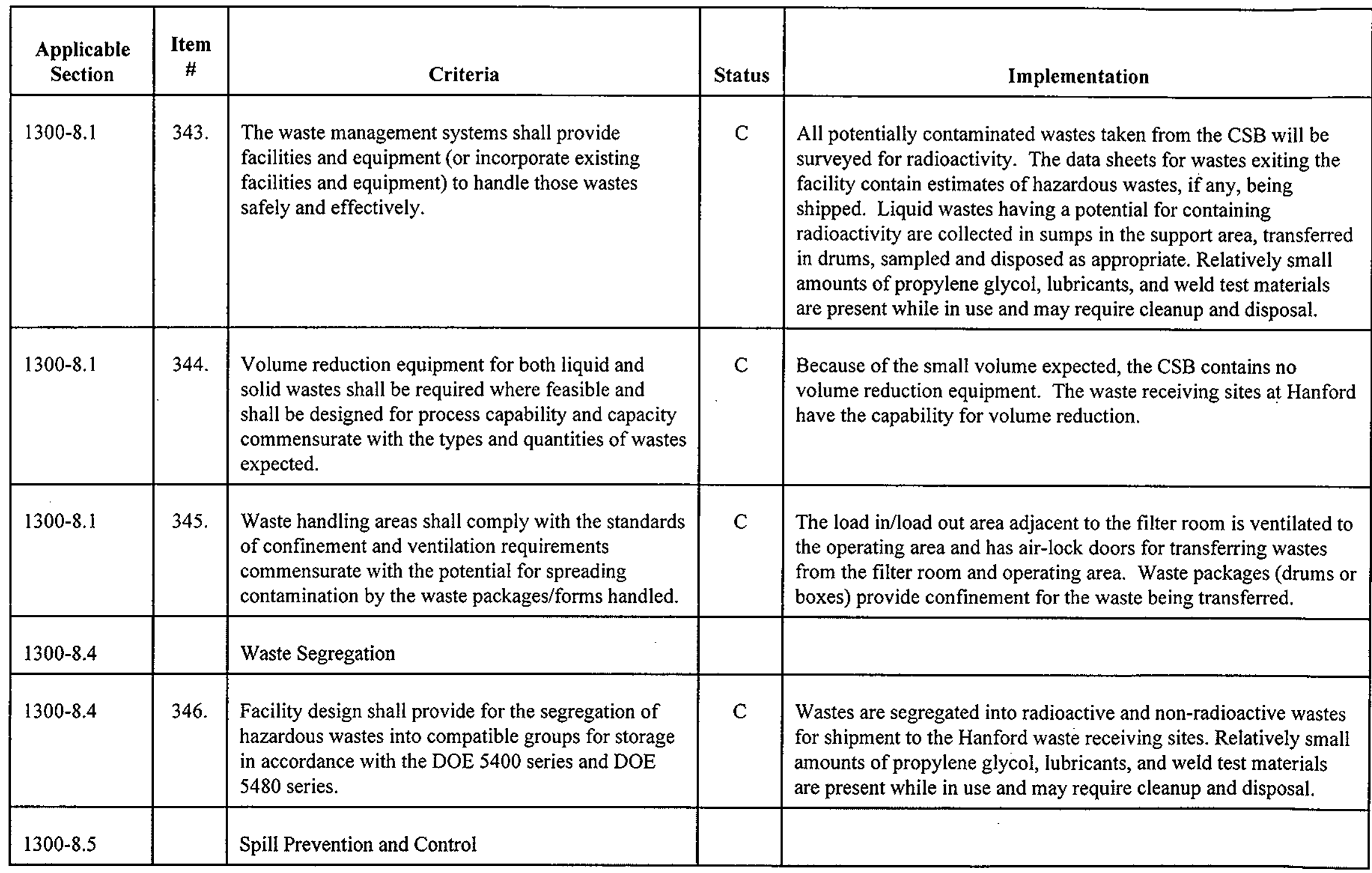




\section{Canister Storage Building Compliance Assessment DOE Order 6430.1A, General Design Criteria}

HNF-4742, Rev. 0

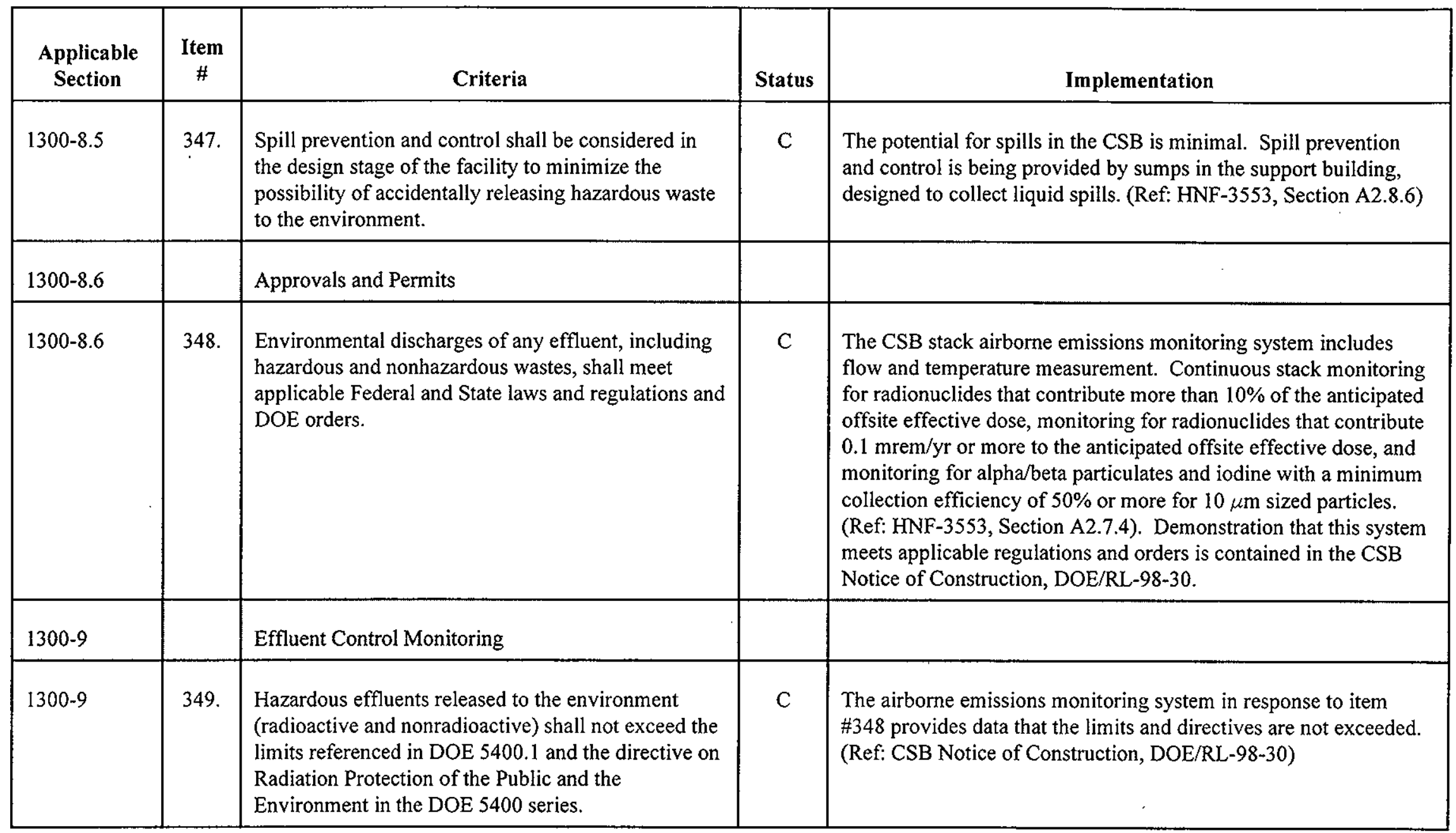




\section{Canister Storage Building Compliance Assessment \\ DOE Order 6430.1A, General Design Criteria}

HNF-4742, Rev. 0

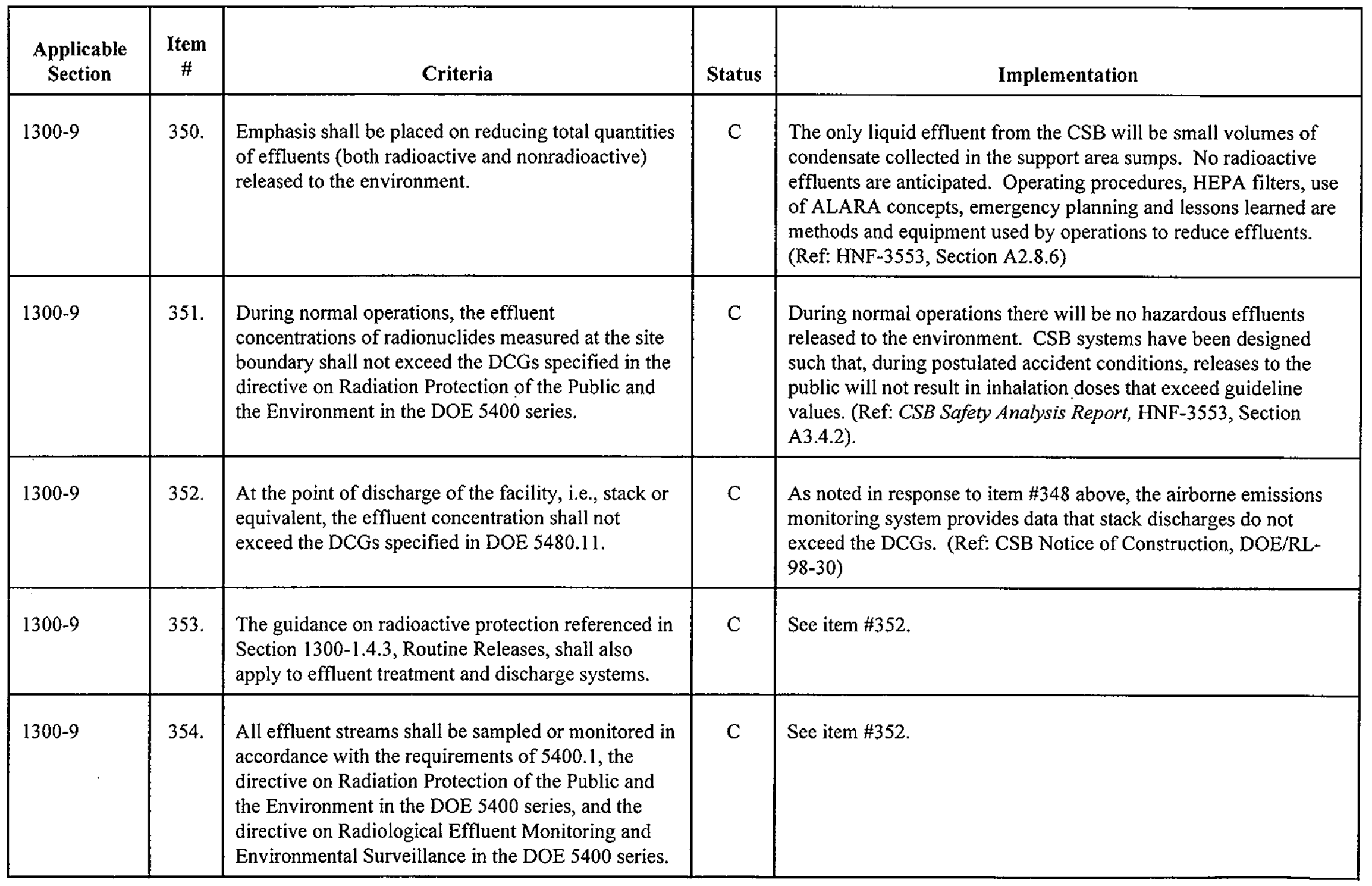




\section{Canister Storage Building Compliance Assessment \\ DOE Order 6430.1A, General Design Criteria}

HNF-4742, Rev. 0

\begin{tabular}{|c|c|c|c|c|}
\hline $\begin{array}{l}\text { Applicable } \\
\text { Section }\end{array}$ & $\begin{array}{l}\text { Item } \\
\#\end{array}$ & Criteria & Status & Implementation \\
\hline $1300-9$ & 356. & $\begin{array}{l}\text { The design of the facility shall include appropriate } \\
\text { groundwater monitoring unless a site-wide program } \\
\text { is provided. This monitoring shall be designed to } \\
\text { detect releases of contaminants to the ground or } \\
\text { ground water. }\end{array}$ & $\mathrm{C}$ & $\begin{array}{l}\text { A site-wide groundwater monitoring program is documented in the } \\
\text { Hanford Environmental Monitoring Report. }\end{array}$ \\
\hline $1300-9$ & 357. & $\begin{array}{l}\text { Groundwater protection programs shall comply with } \\
\text { DOE } 5400.1 \text {, DOE } 5400.3 \text {, and the directive on } \\
\text { Radiation Protection of the Public and the } \\
\text { Environment in the DOE } 5400 \text { series. }\end{array}$ & $\mathrm{C}$ & $\begin{array}{l}\text { A site-wide groundwater monitoring program is documented in the } \\
\text { Hanford Environmental Monitoring Report. }\end{array}$ \\
\hline $1300-11$ & & Decontamination and Decommissioning & & \\
\hline $1300-11.1$ & & Decontamination & & \\
\hline $1300-11.1$ & 358. & $\begin{array}{l}\text { Design of the areas in a facility that may become } \\
\text { contaminated with radioactive or other hazardous } \\
\text { materials under normal or abnormal operating } \\
\text { conditions shall incorporate measures to simplify } \\
\text { future decontamination. }\end{array}$ & $\mathrm{C}$ & $\begin{array}{l}\text { CSB facilities and equipment have been designed to minimize } \\
\text { locations for accumulation of contamination. For example, the } \\
\text { equipment surfaces are smooth and designed for ease of } \\
\text { decontamination. HEPA filters are located close to the potential } \\
\text { source of particulate contamination to limit the length of pipes and } \\
\text { ducts that have the potential for becoming contaminated. The } \\
\text { concrete surfaces have a sealing coat, which provides for ease of } \\
\text { decontamination. (Ref: HNF-3553, Section 16.3) }\end{array}$ \\
\hline
\end{tabular}




\section{Canister Storage Building Compliance Assessment \\ DOE Order 6430.1A, General Design Criteria}

HNF-4742, Rev. 0

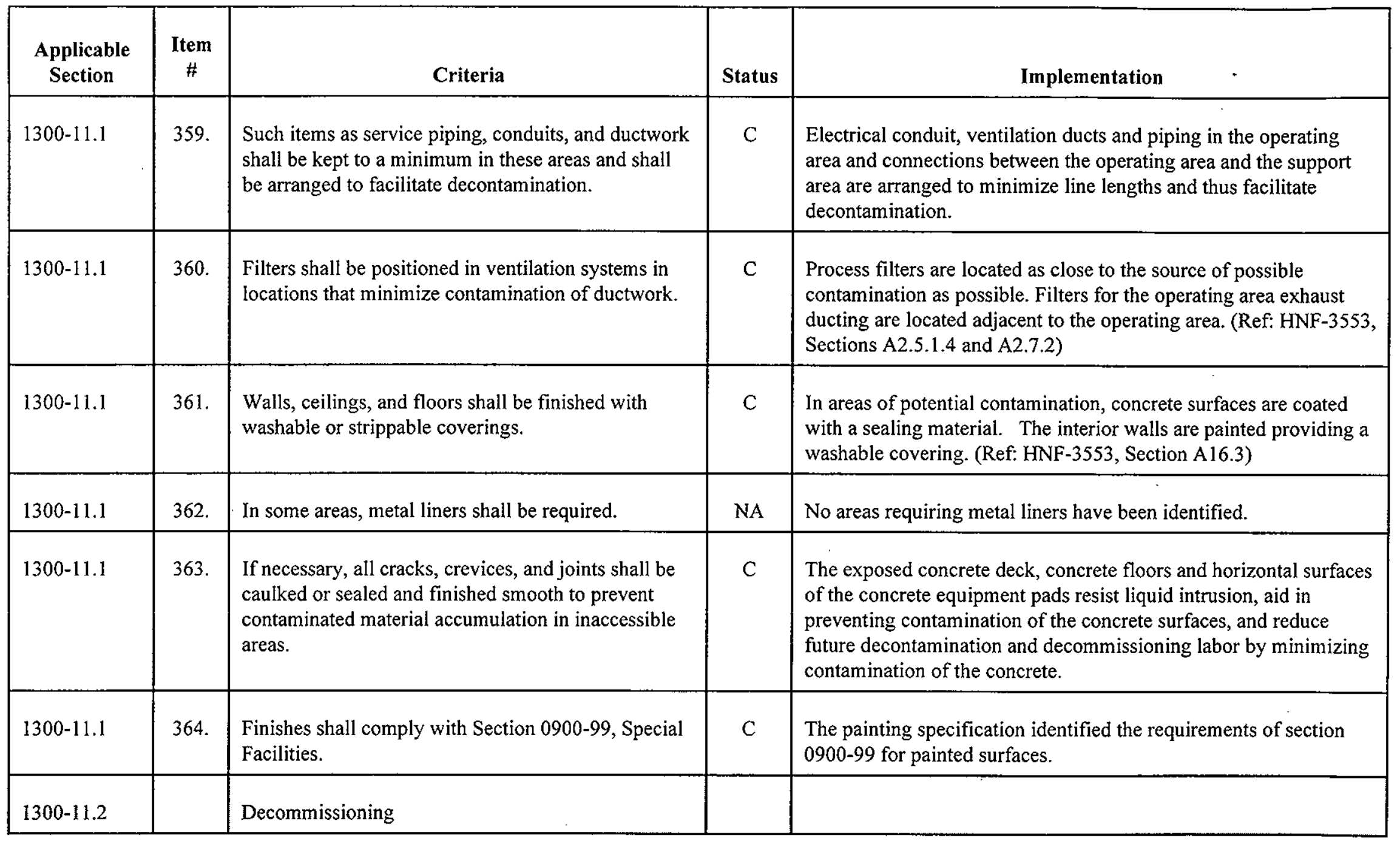




\section{Canister Storage Building Compliance Assessment DOE Order 6430.1A, General Design Criteria}

\begin{tabular}{|c|c|c|c|c|}
\hline $\begin{array}{l}\text { Applicable } \\
\text { Section }\end{array}$ & $\begin{array}{c}\text { Item } \\
\#\end{array}$ & Criteria & Status & Implementation \\
\hline $1300-11.2$ & 366. & $\begin{array}{l}\text { Decommissioning of special facilities is of utmost } \\
\text { importance. The facility design shall include features } \\
\text { that will facilitate decontamination for future } \\
\text { decommissioning, increase the potential for other } \\
\text { uses, or both. }\end{array}$ & $\mathrm{C}$ & Note response to item $\# 365$, above. \\
\hline $1300-12$ & & Human Factors Engineering & & \\
\hline $1300-12.1$ & & Coverage & & \\
\hline
\end{tabular}




\section{Canister Storage Building Compliance Assessment \\ DOE Order 6430.1A, General Design Criteria}

HNF-4742, Rev. 0

\begin{tabular}{|c|c|c|c|c|}
\hline $\begin{array}{l}\text { Applicable } \\
\text { Section }\end{array}$ & $\begin{array}{c}\text { Item } \\
\#\end{array}$ & Criteria & Status & Implementation \\
\hline $1300-12.3 .3$ & & Requirements Analyses & & \\
\hline $1300-12.3 .3$ & 368. & $\begin{array}{l}\text { A systems requirements analysis appropriate to the } \\
\text { level of importance of the system and the level of } \\
\text { risk associated with system failure shall be performed } \\
\text { as an integral part of the design process and shall } \\
\text { include human factors engineering considerations. }\end{array}$ & $\mathrm{C}$ & $\begin{array}{l}\text { The human factors evaluation addressed the relative importance } \\
\text { and risks of CSB systems. For example, the CSB has a control } \\
\text { room containing the DCS and the MHM has an operator control } \\
\text { console. NUREG } 0700 \text { and Mil STD } 1472 \text { D requirements were } \\
\text { applied in designing the DCS and MHM control panels. The } \\
\text { MHM vendor completed a human factors engineering plan and } \\
\text { human factors review of the MHM systems using man-machine } \\
\text { interface criteria. A review was conducted of both control console } \\
\text { designs and layouts and suggestions were incorporated to improve } \\
\text { ease of operation and minimize the potential for mis-operation. } \\
\text { (Ref: HNF-3553, Section A13.5.7) }\end{array}$ \\
\hline $1300-12.3 .3$ & 369. & $\begin{array}{l}\text { Decisions concerning which system functions to } \\
\text { allocate to the human versus the machine shall be } \\
\text { determined by analyses of system functions required, } \\
\text { impact of error or no action on safety, and a } \\
\text { comparison of human capabilities and equipment } \\
\text { capabilities for the separate system functions. }\end{array}$ & $\mathrm{C}$ & Note response to item \# 368. \\
\hline
\end{tabular}




\section{Canister Storage Building Compliance Assessment DOE Order 6430.1A, General Design Criteria}

HNF-4742, Rev. 0

\begin{tabular}{|c|c|c|c|c|}
\hline $\begin{array}{c}\text { Applicable } \\
\text { Section }\end{array}$ & $\begin{array}{c}\text { Item } \\
\#\end{array}$ & Criteria & Status & Implementation \\
\hline $1300-12.3 .4$ & & Process System Design Interfaces & & \\
\hline $1300-12.3 .4$ & 371. & $\begin{array}{l}\text { The design or the selection of equipment to be } \\
\text { operated and maintained by personnel shall include } \\
\text { the application of human factors engineering criteria } \\
\text { together with other appropriate design criteria. }\end{array}$ & $\mathrm{C}$ & $\begin{array}{l}\text { There are minimal process systems within the CSB. The Sample/ } \\
\text { Weld station were addressed in the recent CSB human factors } \\
\text { engineering analysis. (Ref: SNF CSB HFE Analysis, Gem } \\
\text { Ergonomics, January 1999). }\end{array}$ \\
\hline $1300-12.4 .1$ & & General & & \\
\hline $1300-12.4 .1$ & 372. & $\begin{array}{l}\text { The organization of operator movements and the } \\
\text { arrangement and accessibility of equipment and } \\
\text { controls in the work area shall facilitate convenient } \\
\text { access to each system component for operation and } \\
\text { maintenance. }\end{array}$ & $\mathrm{C}$ & $\begin{array}{l}\text { The operation of the MHM is the main area where human machine } \\
\text { interfaces are required. The MHM vendor completed a human } \\
\text { factors engineering plan and human factors review of the MHM } \\
\text { systems using man-machine interface criteria. The suggestions for } \\
\text { improvement of the MHM control system and the DCS system } \\
\text { were incorporated. The formality and the extent of the human } \\
\text { factors engineering program has been graded on the basis of the } \\
\text { extent of the human interaction, the overall design effort, and the } \\
\text { risk associated with human performance failures. Due to the } \\
\text { inherent design simplicity of the CSB, its passive nature, and its } \\
\text { limited access, instrumentation and control systems requirements } \\
\text { are minimal. (Ref: HNF-3553, Section A13.5) }\end{array}$ \\
\hline
\end{tabular}




\section{Canister Storage Building Compliance Assessment \\ DOE Order 6430.1A, General Design Criteria}

\begin{tabular}{|c|c|c|c|c|}
\hline $\begin{array}{l}\text { Applicable } \\
\text { Section }\end{array}$ & $\begin{array}{c}\text { Item } \\
\#\end{array}$ & Criteria & Status & Implementation \\
\hline $1300-12.4 .3$ & & Environmental Considerations & & \\
\hline $1300-12.4 .3$ & 373. & $\begin{array}{l}\text { Adequate light levels are necessary to ensure } \\
\text { optimum performance in all work areas. Glare and } \\
\text { shadowing shall be avoided. For recommended } \\
\text { control room illumination levels, luminance ratios, } \\
\text { reflectance levels and further lighting considerations, } \\
\text { see Section } 1655 \text {, Interior lighting, and NUREG } \\
0700 \text {, Section } 6.1 \text {. }\end{array}$ & Open & $\begin{array}{l}\text { Lighting systems for the CSB were designed using the } \\
\text { requirements of the IES Lighting Handbook-1987 and ASHRAE } \\
90-75 \mathrm{R} \text {. High intensity discharge lights are used in the high bay } \\
\text { areas. Fluorescent lights are provided in the support building } \\
\text { rooms. Low brightness, low glare lights provide light in the } \\
\text { control room. Lighting fixtures in the personnel decontamination } \\
\text { room and the battery room are vapor tight fluorescent lamps. The } \\
\text { sample/weld station will add local lighting. Lighting levels in the } \\
\text { CSB will be re-evaluated during pre-operational testing and } \\
\text { adjusted where needed. (Ref: "SNF CSB HFE Analysis," Gem } \\
\text { Ergonomics, January 1999). } \\
\text { Design Basis Document (DBD) Section } 5.0\end{array}$ \\
\hline $1300-12.4 .3$ & & Emergency Lighting & & \\
\hline $1300-12.4 .3$ & 374. & $\begin{array}{l}\text { Emergency lighting systems shall be provided as } \\
\text { required by NFPA } 101 \text {. A control room emergency } \\
\text { lighting system shall be automatically activated and } \\
\text { immediately available for a stated minimum length } \\
\text { of time on failure of the normal lighting system. }\end{array}$ & $\mathrm{C}$ & $\begin{array}{l}\text { Emergency lighting consists of individual lighting fixtures } \\
\text { powered by an integral battery and self-luminous exit signs. These } \\
\text { lights are installed in areas where egress routes are identified -- this } \\
\text { is in compliance with NFPA-101. (Ref: HNF-3553, Sections } \\
\text { A2.4.4.2 and A2.4.4.3) }\end{array}$ \\
\hline
\end{tabular}




\section{Canister Storage Building Compliance Assessment \\ DOE Order 6430.1A, General Design Criteria}

HNF-4742, Rev. 0

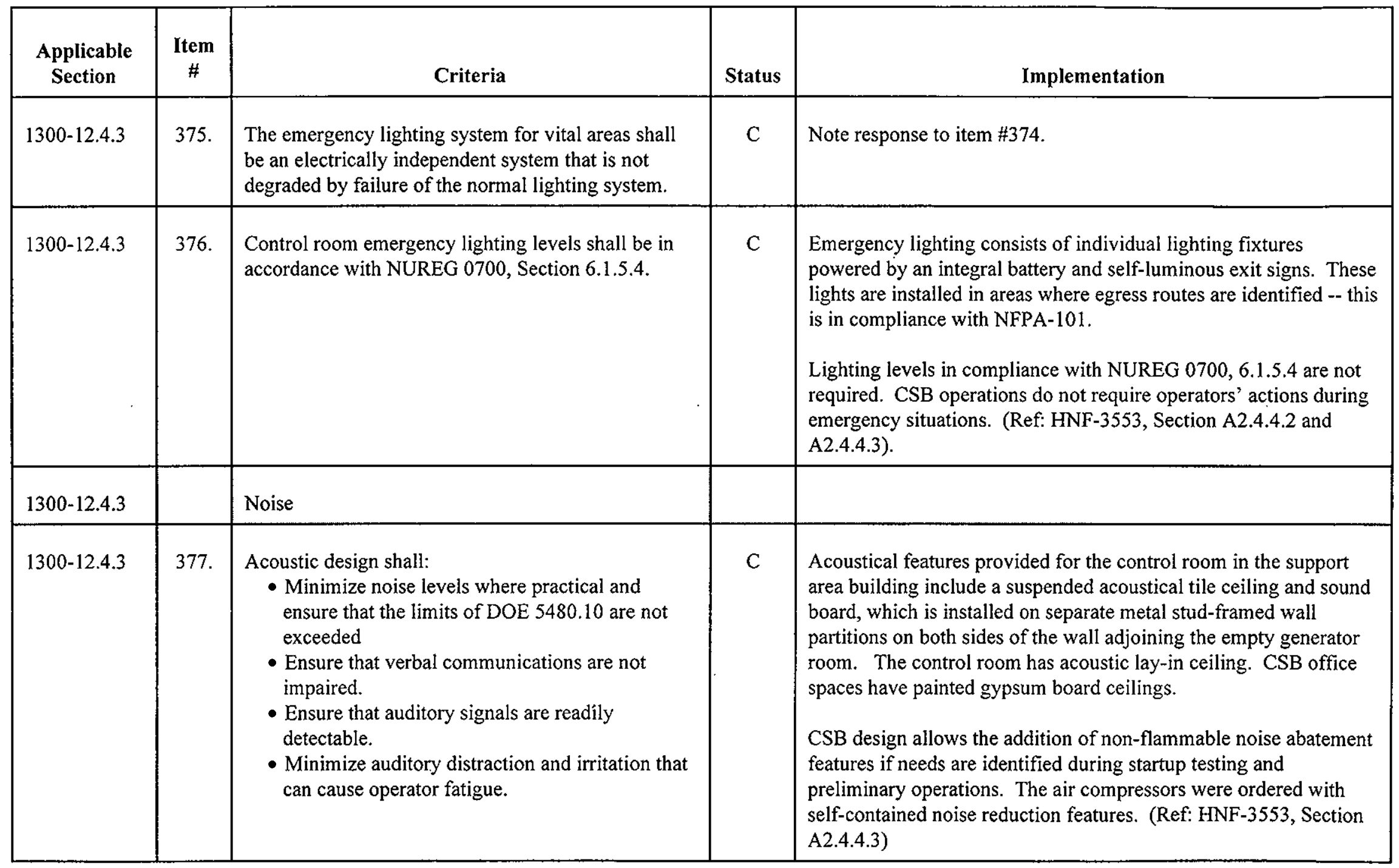




\section{Canister Storage Building Compliance Assessment DOE Order 6430.1A, General Design Criteria}

HNF-4742, Rev. 0

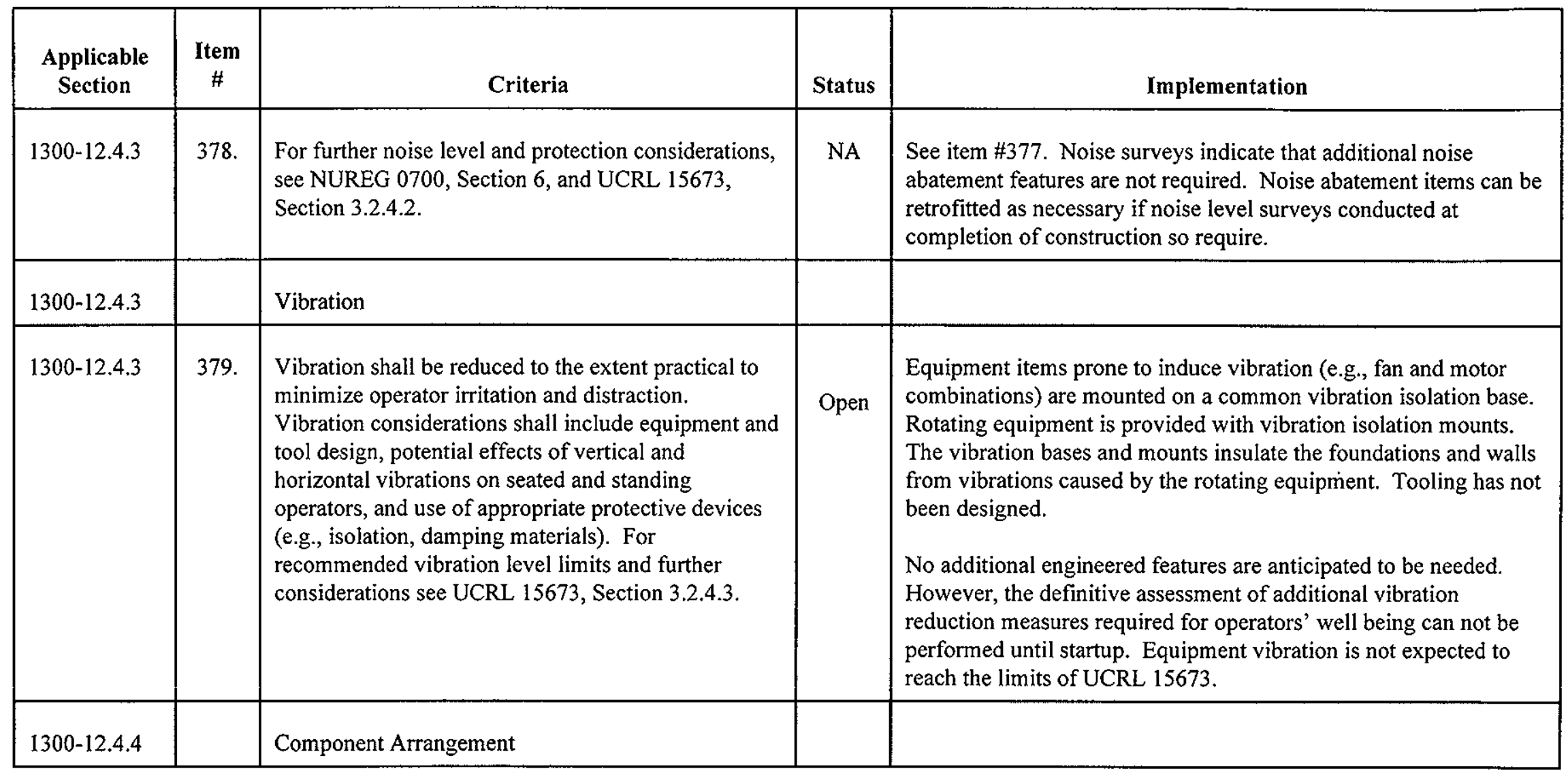




\section{Canister Storage Building Compliance Assessment DOE Order 6430.1A, General Design Criteria}

HNF-4742, Rev. 0

\begin{tabular}{|c|c|c|c|c|}
\hline $\begin{array}{l}\text { Applicable } \\
\text { Section }\end{array}$ & $\begin{array}{l}\text { Item } \\
\#\end{array}$ & Criteria & Status & Implementation \\
\hline $1300-12.4 .4$ & 381. & $\begin{array}{l}\text { Component arrangement shall promote easy } \\
\text { association of related controls and displays or other } \\
\text { related components. Displays are usually placed } \\
\text { above and relatively close to the related control. }\end{array}$ & $\mathrm{C}$ & Note response to \# 380 . \\
\hline $1300-12.4 .5$ & & Protective Equipment & & \\
\hline
\end{tabular}




\section{Canister Storage Building Compliance Assessment DOE Order 6430.1A, General Design Criteria}

HNF-4742, Rev. 0

\begin{tabular}{|c|c|c|c|c|}
\hline $\begin{array}{l}\text { Applicable } \\
\text { Section }\end{array}$ & $\begin{array}{c}\text { Item } \\
\#\end{array}$ & Criteria & Status & Implementation \\
\hline $1300-12.4 .5$ & 383. & $\begin{array}{l}\text { The design or selection of protective equipment shall } \\
\text { be such that it minimizes the impairment of } \\
\text { operational and maintenance performance. It shall } \\
\text { provide adequate tactile sensitivity and provide the } \\
\text { ability to see, reach, move, communicate, and hear. }\end{array}$ & C & $\begin{array}{l}\text { No special personal protective equipment is required for CSB } \\
\text { operations. Requirements for specific Personal Protective } \\
\text { Equipment are established during the normal job safety analysis } \\
\text { activities. }\end{array}$ \\
\hline $1300-12.4 .6$ & 384. & $\begin{array}{l}\text { Displays shall provide only the information about } \\
\text { system status and parameter values that is needed to } \\
\text { meet task requirements in normal, abnormal and } \\
\text { emergency situations. Failure of a display of any } \\
\text { type shall be easily recognized and shall not affect } \\
\text { equipment or system performance. }\end{array}$ & C & $\begin{array}{l}\text { The Distributed Control System (DCS) serves as the central } \\
\text { monitoring system for CSB facility and equipment conditions. The } \\
\text { DCS has the capability of displaying and annunciating failure of } \\
\text { any monitored component. The DCS will monitor and display all } \\
\text { Alarms in the "Alarm Status" portion of most display screens and } \\
\text { on the "Alarm Summary Display" screen. (See DCS System } \\
\text { Design Descriptions, Rev. 2, Section 1.1.) } \\
\text { Onboard display devices are installed in the MHM, which are } \\
\text { designed for specific operations of the MHM. The overall MHM } \\
\text { control system is equipped with numerous safety interlocks to } \\
\text { protect against operating errors which could result in damage to the } \\
\text { deck or the MCO as well as to guard against damage to the MHM } \\
\text { or its associated equipment. }\end{array}$ \\
\hline
\end{tabular}




\section{Canister Storage Building Compliance Assessment \\ DOE Order 6430.1A, General Design Criteria}

HNF-4742, Rev. 0

\begin{tabular}{|c|c|c|c|c|}
\hline $\begin{array}{l}\text { Applicable } \\
\text { Section }\end{array}$ & $\begin{array}{c}\text { Item } \\
\#\end{array}$ & Criteria & Status & Implementation \\
\hline $1300-12.4 .8$ & & Warning and Annunciator Systems & & \\
\hline
\end{tabular}




\section{Canister Storage Building Compliance Assessment DOE Order 6430.1A, General Design Criteria}

\begin{tabular}{|c|c|c|c|c|}
\hline $\begin{array}{l}\text { Applicable } \\
\text { Section }\end{array}$ & $\begin{array}{c}\text { Item } \\
\#\end{array}$ & Criteria & Status & Implementation \\
\hline $1300-12.4 .8$ & 387. & $\begin{array}{l}\text { Each stimulus shall be easily distinguishable from } \\
\text { other stimuli in the same modality but it shall not be } \\
\text { a distraction. If an alarm can be one of many similar } \\
\text { alarms that may occur simultaneously, it shall be } \\
\text { easy to locate. }\end{array}$ & $\mathrm{C}$ & See item \#386. Alarms are distinct and distinguishable. \\
\hline
\end{tabular}




\section{Canister Storage Building Compliance Assessment DOE Order 6430.1A, General Design Criteria}

HNF-4742, Rev. 0

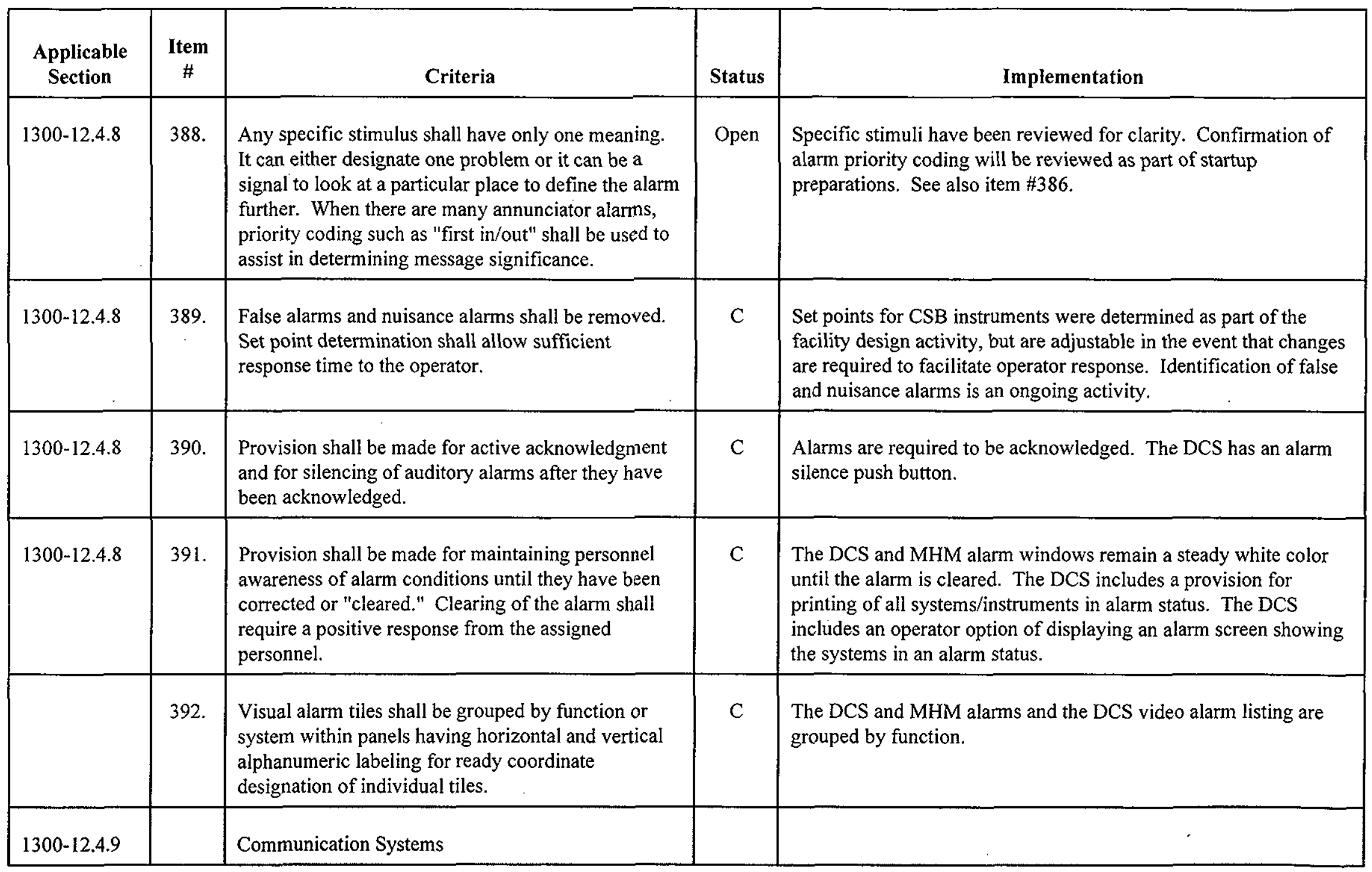




\section{Canister Storage Building Compliance Assessment DOE Order 6430.1A, General Design Criteria}

HNF-4742, Rev. 0

\begin{tabular}{|c|c|c|c|c|}
\hline $\begin{array}{l}\text { Applicable } \\
\text { Section }\end{array}$ & $\begin{array}{c}\text { Item } \\
\#\end{array}$ & Criteria & Status & Implementation \\
\hline $1300-12.4 .10$ & & Maintainability & & . \\
\hline $1300-12.4 .10$ & 394. & UCRL 15673 shall be considered for system design. & C & $\begin{array}{l}\text { The CSB utilized NUREG } 0700 \text {, Mil Std } 1472 \text { D, and UCRL } 15673 \\
\text { for guidance in human factors design. The Human Factors study } \\
\text { recently completed for the CSB indicates that guidance provided in } \\
\text { UCRL } 15673 \text { was complied with in the CSB design. }\end{array}$ \\
\hline $1300-12.4 .11$ & & Labels & & \\
\hline $1300-12.4 .11$ & 395. & $\begin{array}{l}\text { Equipment and any parts of that equipment to be } \\
\text { used by personnel shall be identified with appropriate } \\
\text { labels. }\end{array}$ & $\mathrm{C}$ & $\begin{array}{l}\text { Labels/tags have been placed on equipment and instruments } \\
\text { identifying the location and function. The labels correspond to the } \\
\text { numbering and identification system used in the plant flow } \\
\text { diagrams. }\end{array}$ \\
\hline $1300-12.4 .11$ & 396. & $\begin{array}{l}\text { The label shall indicate clearly and concisely the } \\
\text { function and purpose of the item being labeled. }\end{array}$ & C & See response to item $\# 395$. \\
\hline $1300-12.4 .11$ & 397. & Label design shall be consistent. & $\mathrm{C}$ & $\begin{array}{l}\text { CSB labeling is done in accordance with CSB labeling guidance } \\
\text { and is consistent within the facility. }\end{array}$ \\
\hline
\end{tabular}




\section{Canister Storage Building Compliance Assessment DOE Order 6430.1A, General Design Criteria}

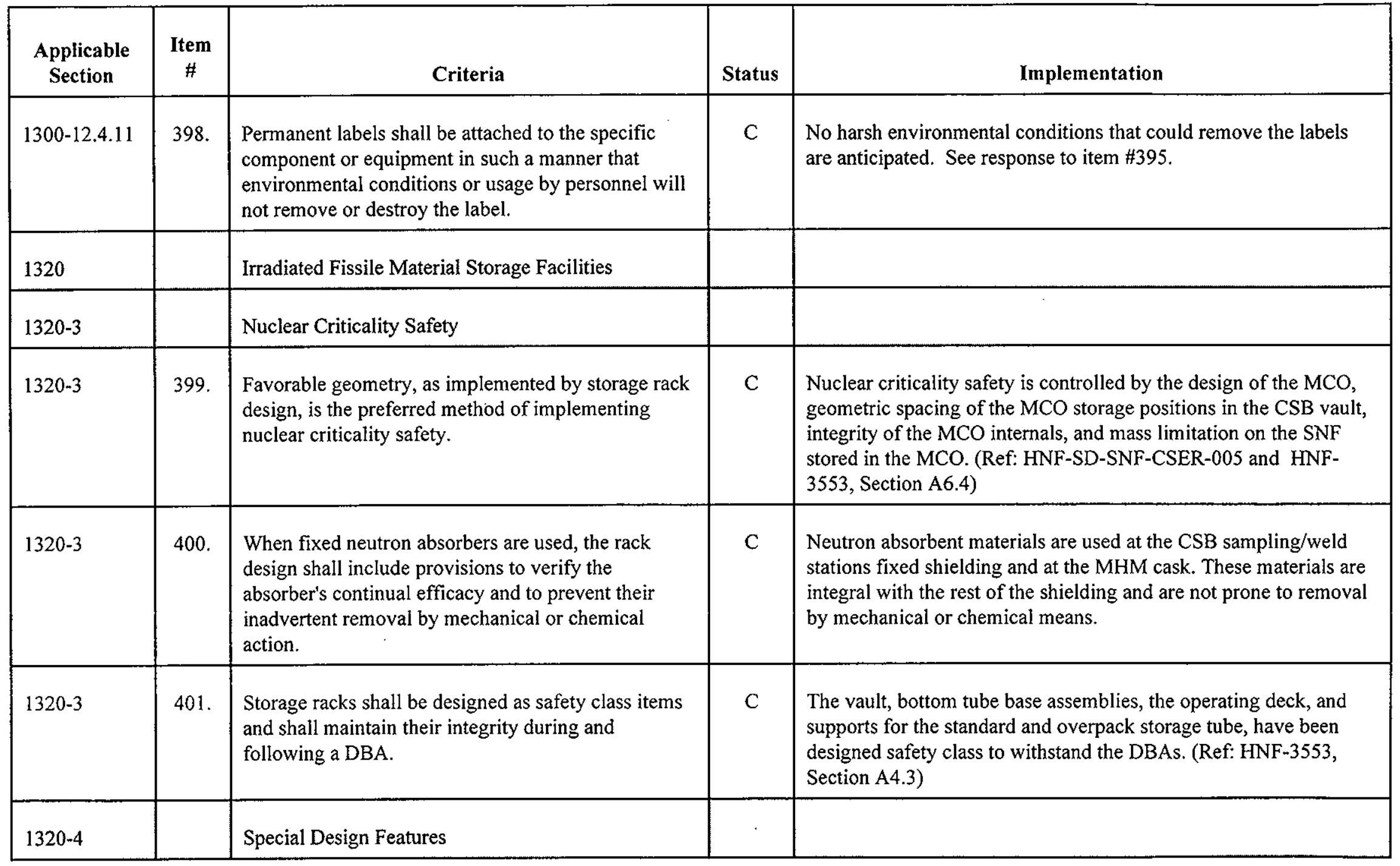




\section{Canister Storage Building Compliance Assessment DOE Order 6430.1A, General Design Criteria}

\begin{tabular}{|c|c|c|c|c|}
\hline $\begin{array}{c}\text { Applicable } \\
\text { Section }\end{array}$ & $\begin{array}{c}\text { Item } \\
\#\end{array}$ & Criteria & Status & Implementation \\
\hline $1320-4$ & 403. & $\begin{array}{l}\text { A system shall be incorporated into the design that } \\
\text { can detect leakage from stored IFM in the event of a } \\
\text { cladding or canning failure that could allow the } \\
\text { escape of fission products and other radioactive } \\
\text { material greater than specified limits. This system } \\
\text { shall include the following: }\end{array}$ & $\mathrm{C}$ & $\begin{array}{l}\text { The tube vent and purge cart has been designed to monitor the } \\
\text { overpack storage tubes containing an MCO that has been } \\
\text { determined to be off-normal (a high pressure detected inside the } \\
\text { cask received from CVDF or a dropped MCO). The tube vent and } \\
\text { purge cart can also be used to monitor standard storage tubes for a } \\
\text { leaking MCO. (Ref: HNF-3553, Section A2.5.3) }\end{array}$ \\
\hline
\end{tabular}




\section{Canister Storage Building Compliance Assessment \\ DOE Order 6430.1A, General Design Criteria}

HNF-4742, Rev. 0

\begin{tabular}{|c|c|c|c|c|}
\hline $\begin{array}{l}\text { Applicable } \\
\text { Section }\end{array}$ & $\begin{array}{c}\text { Item } \\
\#\end{array}$ & Criteria & Status & Implementation \\
\hline $1320-4$ & 407. & $\begin{array}{l}\text { - The design professional of the IFMSF shall } \\
\text { consider provisions that allow for the interim } \\
\text { canning of leaking assemblies until disposal. }\end{array}$ & C & $\begin{array}{l}\text { For MCOs, interim canning of suspect MCOs is achieved by the } \\
\text { placement of the suspect MCO into an overpack storage tube. (Ref: } \\
\text { HNF- } 3553 \text {, Section A2.4.3) } \\
\text { The sampling/weld station pits have welding equipment for } \\
\text { attaching a welded cap to each MCO. }\end{array}$ \\
\hline
\end{tabular}




\section{Canister Storage Building Compliance Assessment DOE Order 6430.1A, General Design Criteria}

\begin{tabular}{|c|c|c|c|c|}
\hline $\begin{array}{l}\text { Applicable } \\
\text { Section }\end{array}$ & $\begin{array}{l}\text { Item } \\
\#\end{array}$ & Criteria & Status & Implementation \\
\hline $1320-4$ & 408. & $\begin{array}{l}\text { The Design professional shall consider the criteria } \\
\text { provided in } 10 \text { CFR } 72 \text { and the following guides for } \\
\text { applicability to IFMSFs: }\end{array}$ & $\mathrm{C}$ & $\begin{array}{l}10 \text { CFR } 72 \text { Criteria have been considered for incorporation into } \\
\text { CSB design. (Ref: WHC-SD-SNF-DB-003) }\end{array}$ \\
\hline $1320-4$ & 409. & - R.G. 3.49 & NA & $\begin{array}{l}\text { Design of an independent water basin type spent fuel storage basin } \\
\text { is not applicable to the CSB dry storage facility. }\end{array}$ \\
\hline $1320-4$ & 410. & - R.G. 3.54 & $\mathrm{C}$ & $\begin{array}{l}\text { Spent fuel heat generation rates have been considered in the design } \\
\text { of the CSB passive cooling system. (Ref: HNF-3553, Section } \\
\text { A2.5.2) }\end{array}$ \\
\hline $1320-5$ & & Confinement Systems & & \\
\hline $1320-5.1$ & & General & & \\
\hline $1320-5.1$ & 411. & $\begin{array}{l}\text { In general, the primary confinement shall be the IFM } \\
\text { cladding or canning. Secondary confinement shall } \\
\text { be established by the facility buildings that enclose } \\
\text { the dry storage area and/or the storage pool and } \\
\text { auxiliary systems. }\end{array}$ & $\mathrm{C}$ & $\begin{array}{l}\text { The MCO is the primary confinement barrier for SNF interim } \\
\text { stored in MCOs at the CSB. The secondary confinement barrier } \\
\text { during shipping, receiving operations and service station unloading } \\
\text { operations is the transportation cask. For other operations in the } \\
\text { CSB, the equipment around the MCO provides secondary } \\
\text { confinement, i.e., the service station pit and service station mobile } \\
\text { tent, the MHM, the sampling/weld station pit and sampling hood, } \\
\text { the standard storage tube/standard storage tube plug, and the } \\
\text { overpack storage tube/overpack storage tube plug. The CSB } \\
\text { operating shelter structure is considered to be a defense-in-depth } \\
\text { feature in the provision of secondary confinement. (Ref: HNF- } \\
3553 \text {, Section A2.6) }\end{array}$ \\
\hline 1320.5 .2 & & Primary Confinement Systems & & \\
\hline
\end{tabular}




\section{Canister Storage Building Compliance Assessment \\ DOE Order 6430.1A, General Design Criteria}

\begin{tabular}{|l|c|l|c|c|}
\hline $\begin{array}{c}\text { Applicable } \\
\text { Section }\end{array}$ & $\begin{array}{c}\text { Item } \\
\text { \# }\end{array}$ & \multicolumn{1}{|c|}{ Criteria } & Status & Implementation \\
\hline $1320-5.2$ & 412. & $\begin{array}{l}\text { The IFM cladding or cans, as appropriate, shall } \\
\text { provide primary confinement during normal and } \\
\text { anticipated operational occurrences. }\end{array}$ & C & The MCO provides primary confinement for SNF in the CSB. \\
\hline $1320-5.2$ & 413. & $\begin{array}{l}\text { The IFM cladding or canning shall be designed to } \\
\text { provide a corrosion-resistant confinement for the } \\
\text { IFM material to prevent an uncontrolled release of } \\
\text { radioactive material. }\end{array}$ & C & $\begin{array}{l}\text { The MCO has been constructed using 1/2" thick stainless steel } \\
\text { (304L for the shell, bottom baseplate and the MCO shield plug) } \\
\text { and designed to Boiler Pressure Vessel Code (ASME 1995), } \\
\text { Section IrI, Subsection NB. (Ref: HNF-SD-SNF-SARR-005) }\end{array}$ \\
\hline $1320-5.3$ & 414. & $\begin{array}{l}\text { The facility building, and ventilation make up the } \\
\text { secondary confinement system. }\end{array}$ & C & $\begin{array}{l}\text { See item \#411. The CSB facility provides appropriate secondary } \\
\text { confinement features for the SNF. (Ref: HNF-3553, Figure A2- } \\
\text { 45.) }\end{array}$ \\
\hline $1320-5.3$ & 415. & $\begin{array}{l}\text { The secondary confinement system shall be designed } \\
\text { to function during normal operations and anticipated } \\
\text { operational occurrences. }\end{array}$ & C & $\begin{array}{l}\text { The secondary confinement systems for the CSB are designed to } \\
\text { function during normal operations and anticipated operational } \\
\text { occurrences. }\end{array}$ \\
\hline $1320-5.3$
\end{tabular}




\section{Canister Storage Building Compliance Assessment DOE Order 6430.1A, General Design Criteria}

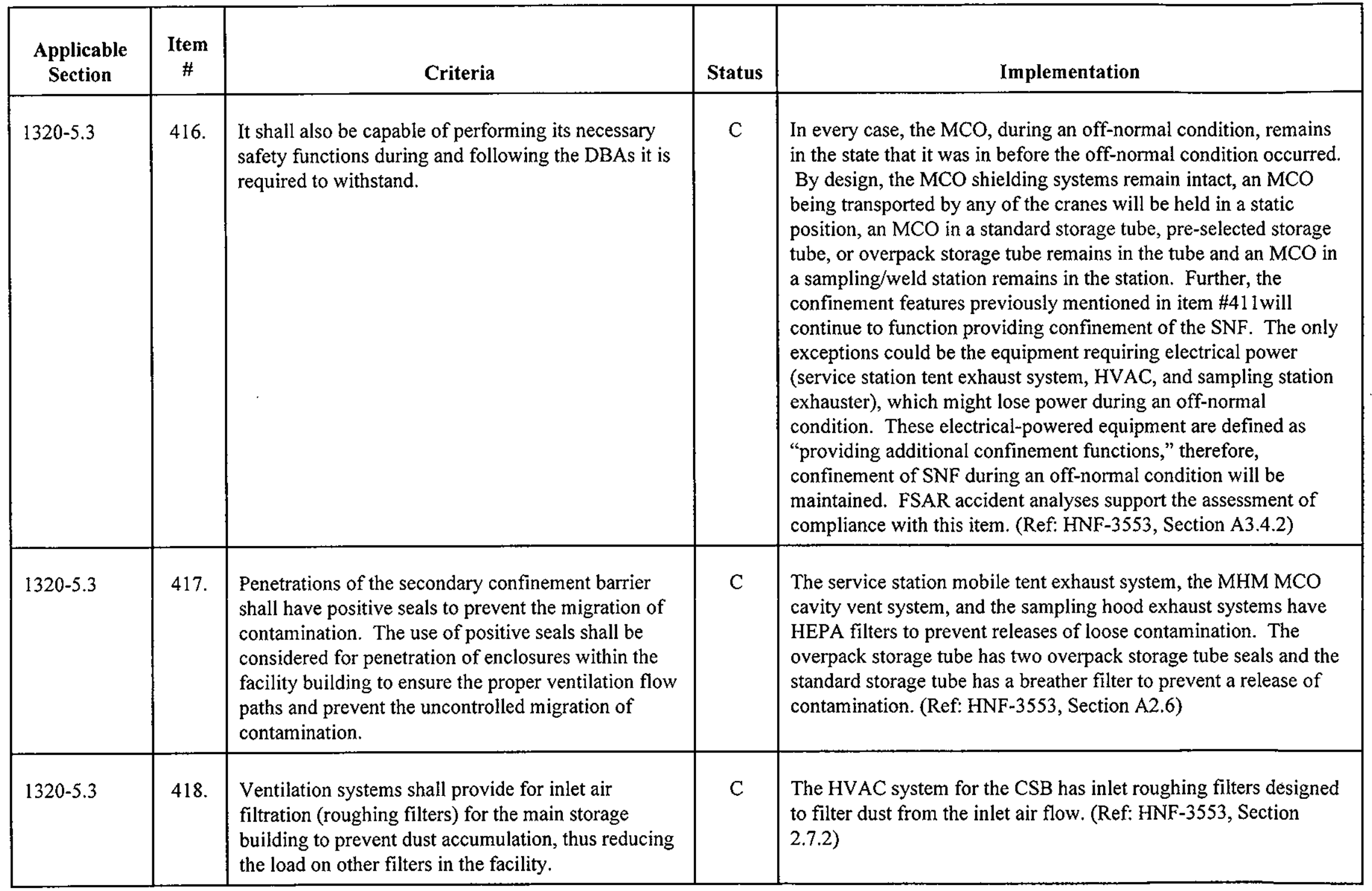




\section{Canister Storage Building Compliance Assessment DOE Order 6430.1A, General Design Criteria}

HNF-4742, Rev. 0

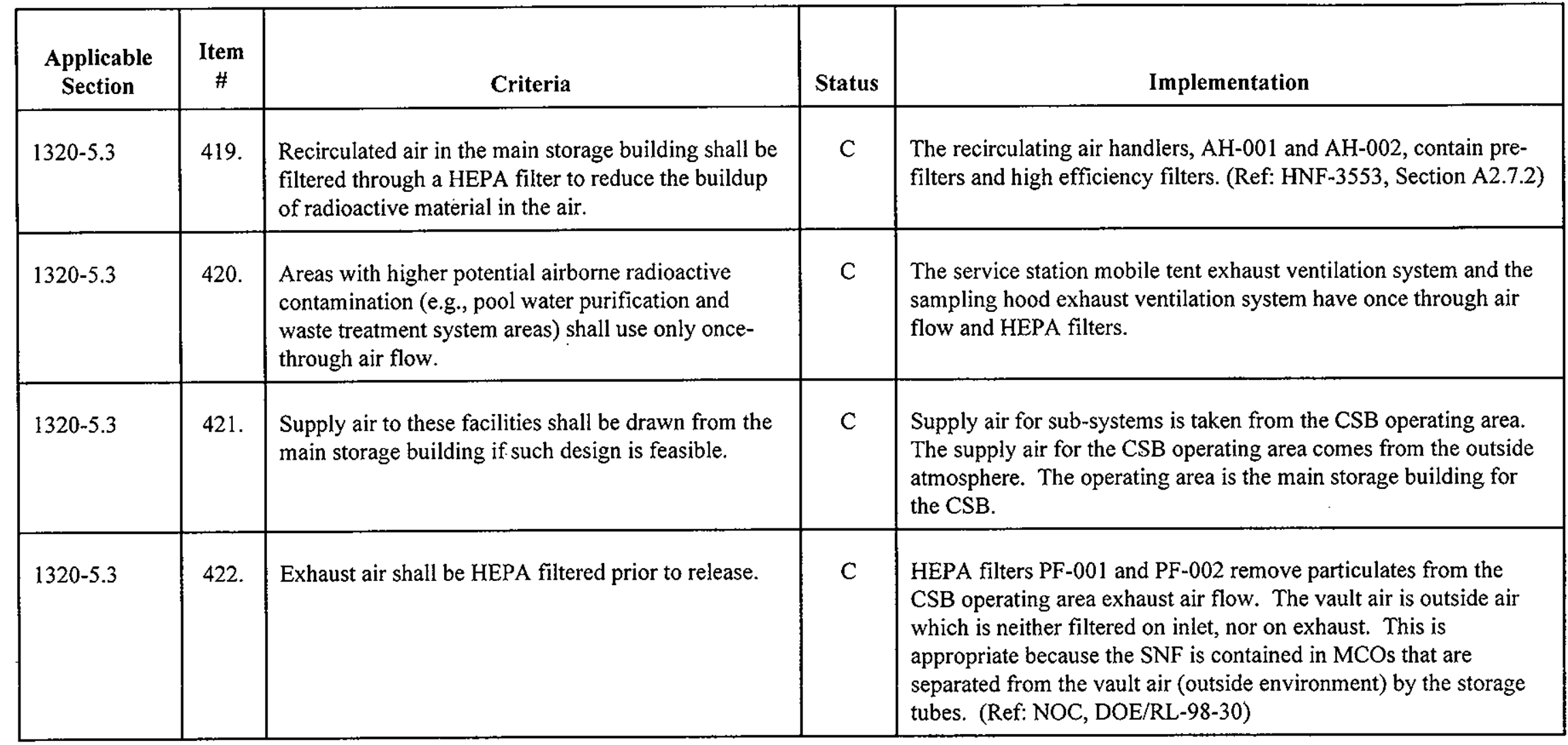




\section{Canister Storage Building Compliance Assessment DOE Order 6430.1A, General Design Criteria}

HNF-4742, Rev. 0

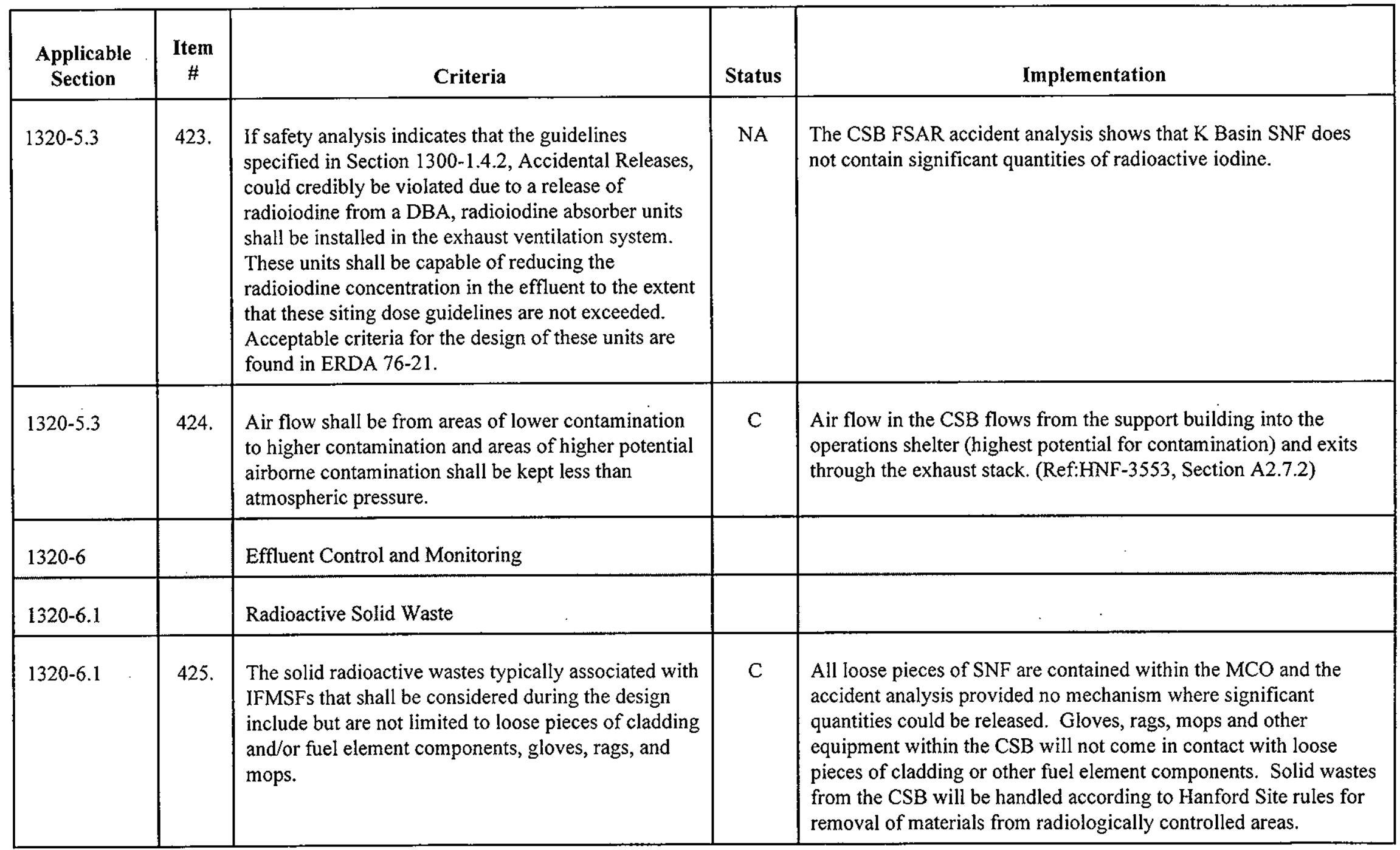




\section{Canister Storage Building Compliance Assessment \\ DOE Order 6430.1A, General Design Criteria}

HNF-4742, Rev. 0

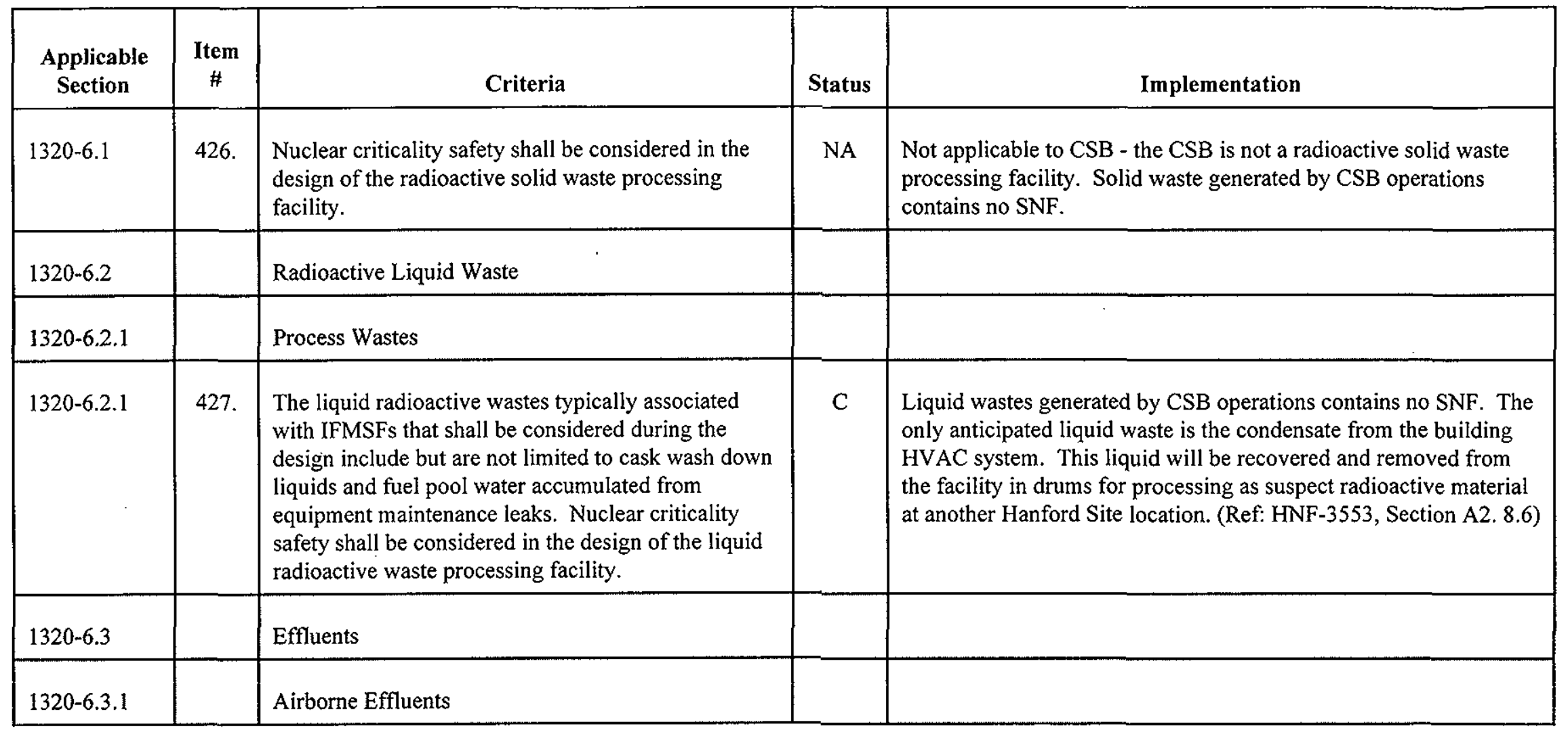




\section{Canister Storage Building Compliance Assessment DOE Order 6430.1A, General Design Criteria}

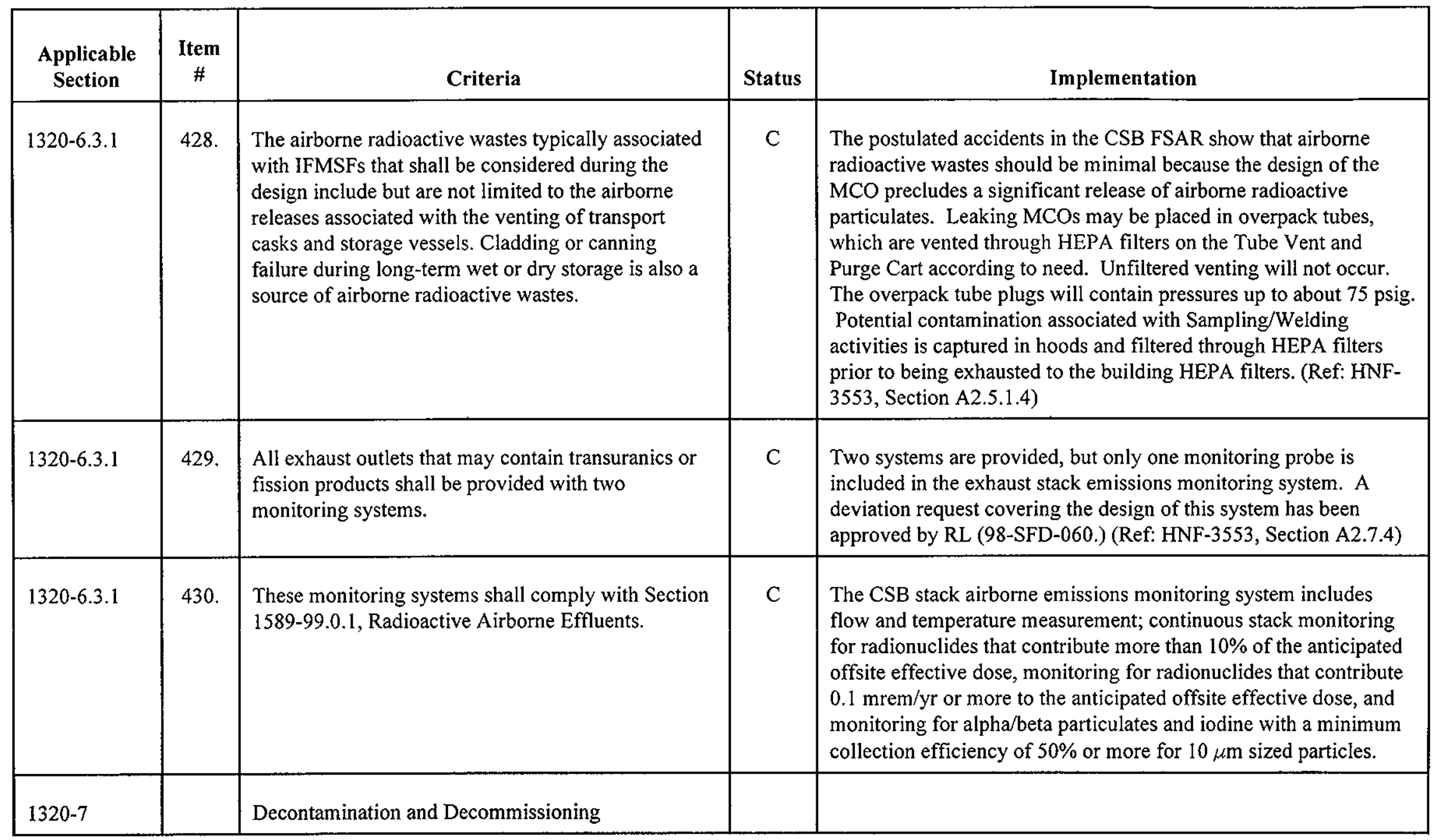




\section{Canister Storage Building Compliance Assessment}

HNF-4742, Rev. 0 DOE Order 6430.1A, General Design Criteria

\begin{tabular}{|l|c|l|c|l|}
\hline $\begin{array}{c}\text { Applicable } \\
\text { Section }\end{array}$ & $\begin{array}{c}\text { Item } \\
\text { \# }\end{array}$ & \multicolumn{1}{|c|}{ Criteria } & Status & Implementation \\
\hline $1320-7$ & 431. & $\begin{array}{l}\text { Decommissioning of the IFMSF is of utmost } \\
\text { importance. The facility design shall include features } \\
\text { that will facilitate decontamination for future } \\
\text { decommissioning. }\end{array}$ & C & $\begin{array}{l}\text { The facility design includes provisions to facilitate } \\
\text { decontamination and decommissioning. (Ref: HNF-3553, Section } \\
\text { A.16) }\end{array}$ \\
\hline
\end{tabular}




\section{Canister Storage Building Compliance Assessment DOE Order 6430.1A, General Design Criteria}

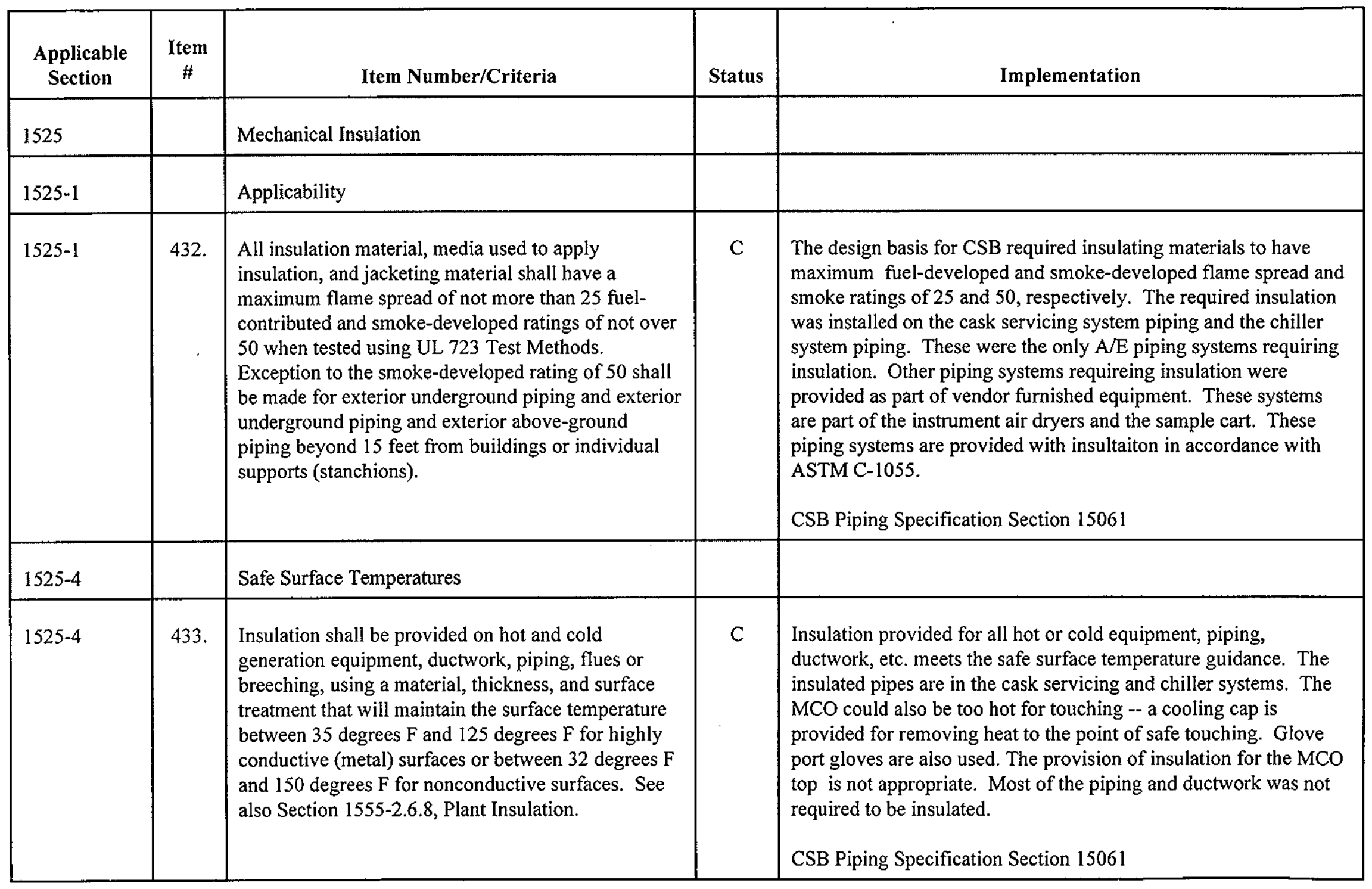




\section{Canister Storage Building Compliance Assessment \\ DOE Order 6430.1A, General Design Criteria}

HNF-4742, Rev. 0

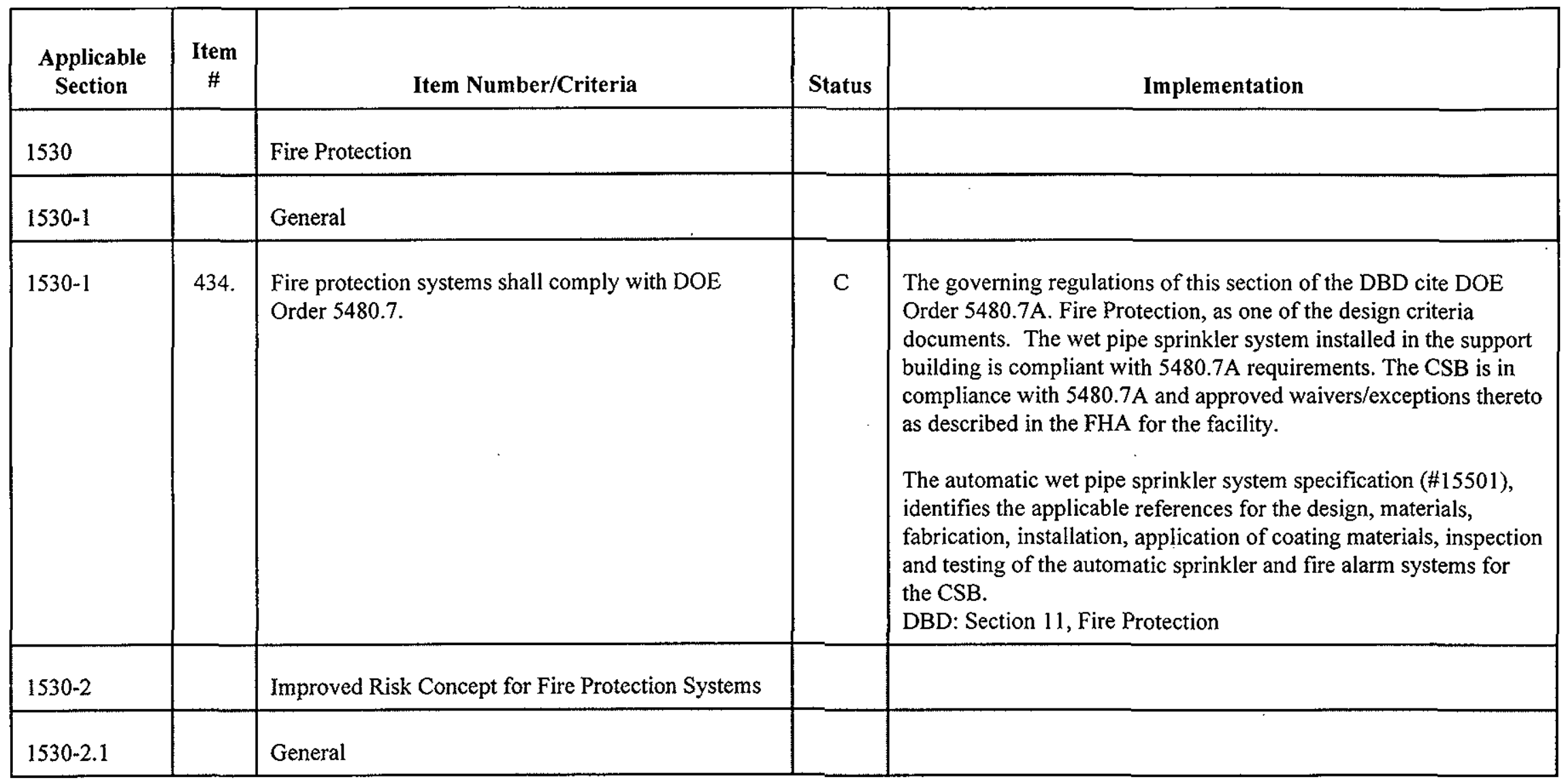




\section{Canister Storage Building Compliance Assessment DOE Order 6430.1A, General Design Criteria}

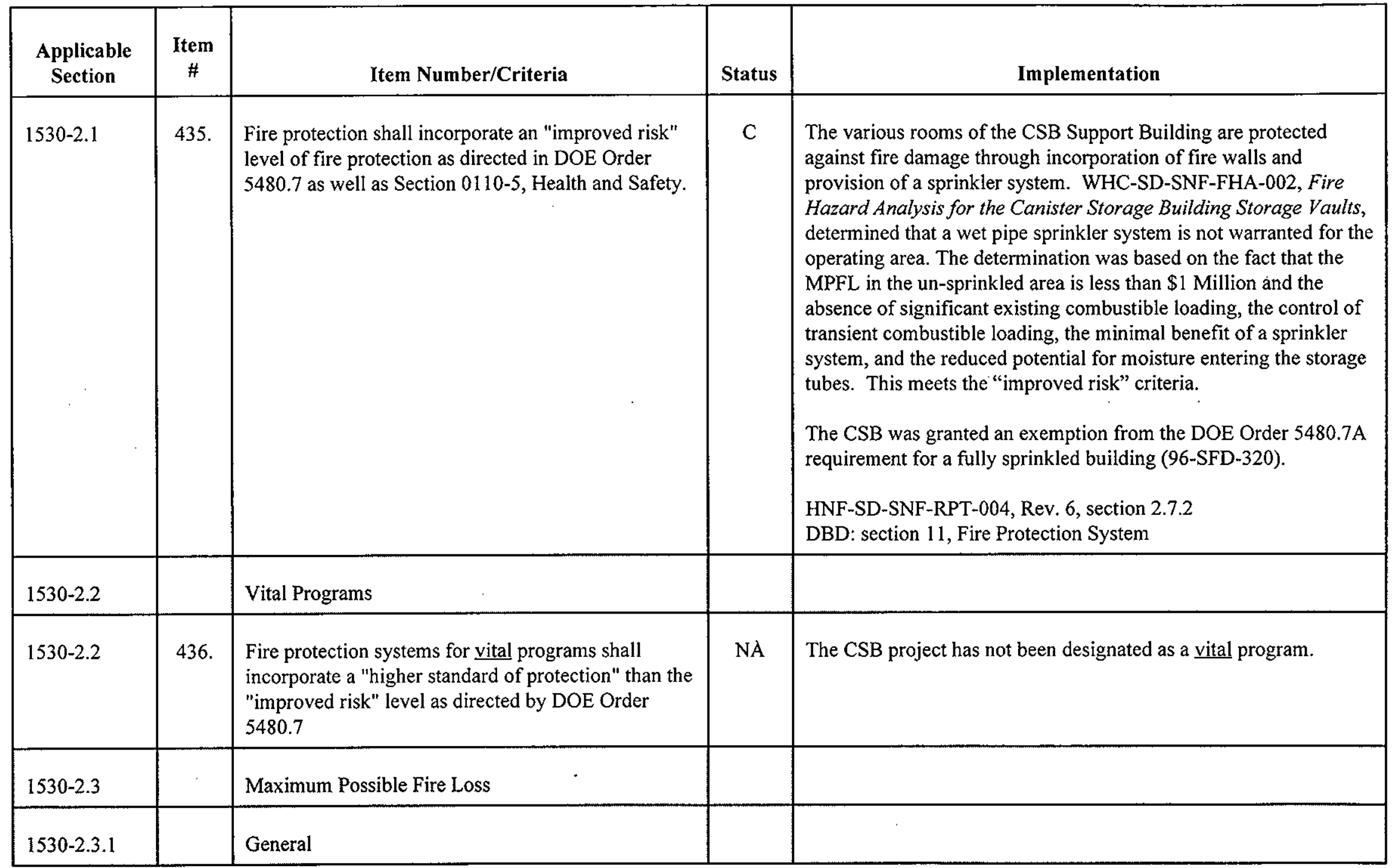




\section{Canister Storage Building Compliance Assessment \\ DOE Order 6430.1A, General Design Criteria}

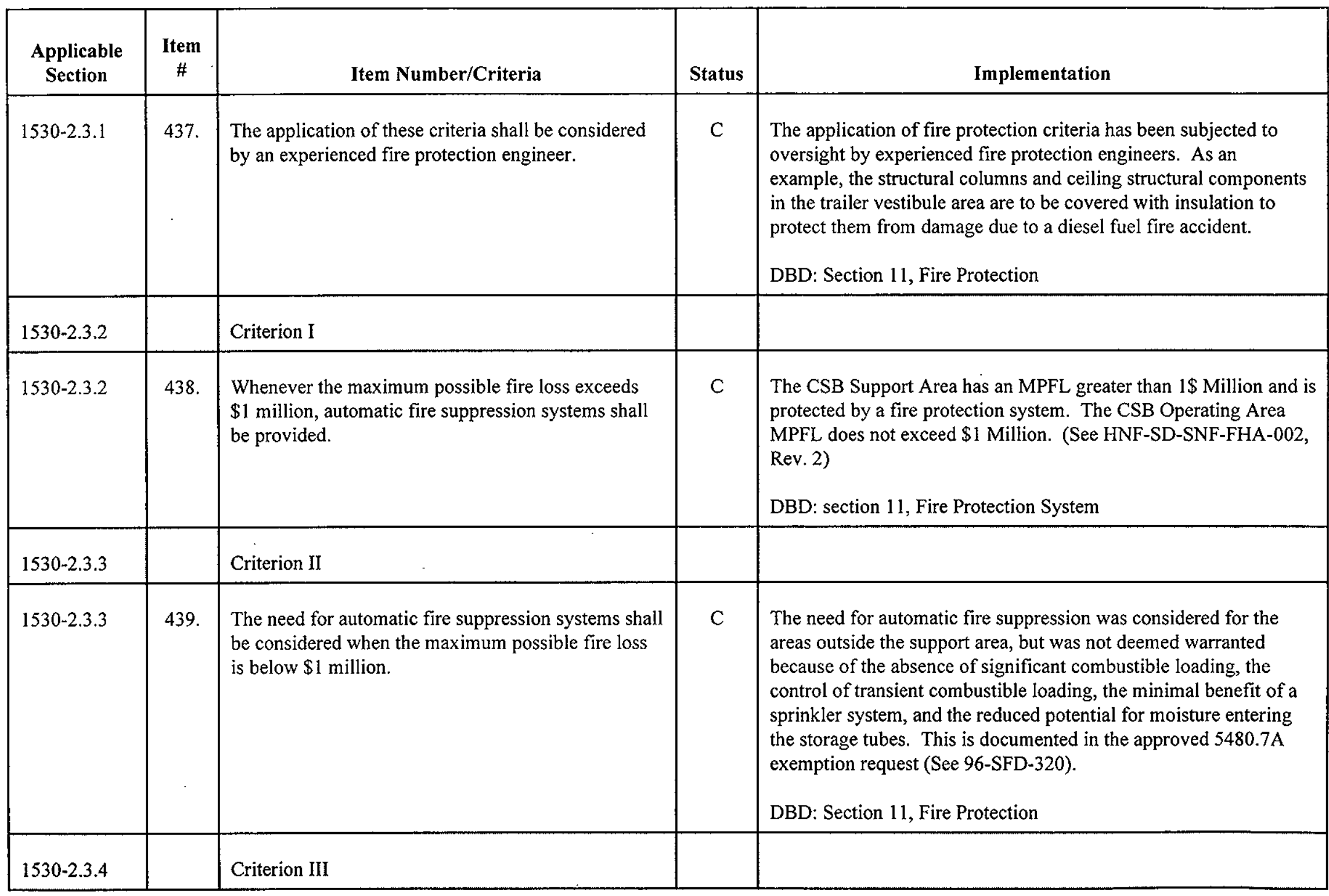




\section{Canister Storage Building Compliance Assessment DOE Order 6430.1A, General Design Criteria}

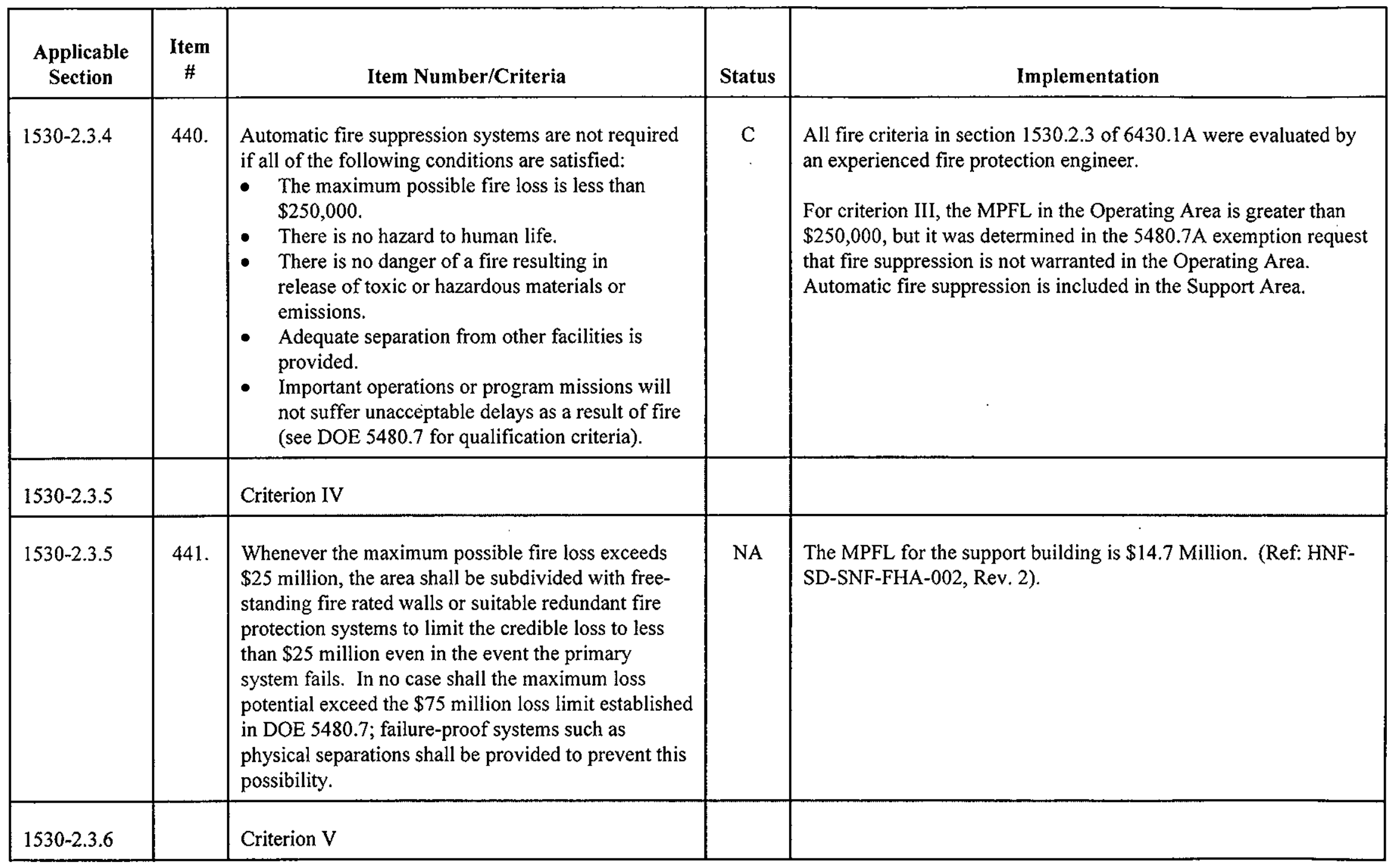




\section{Canister Storage Building Compliance Assessment DOE Order 6430.1A, General Design Criteria}

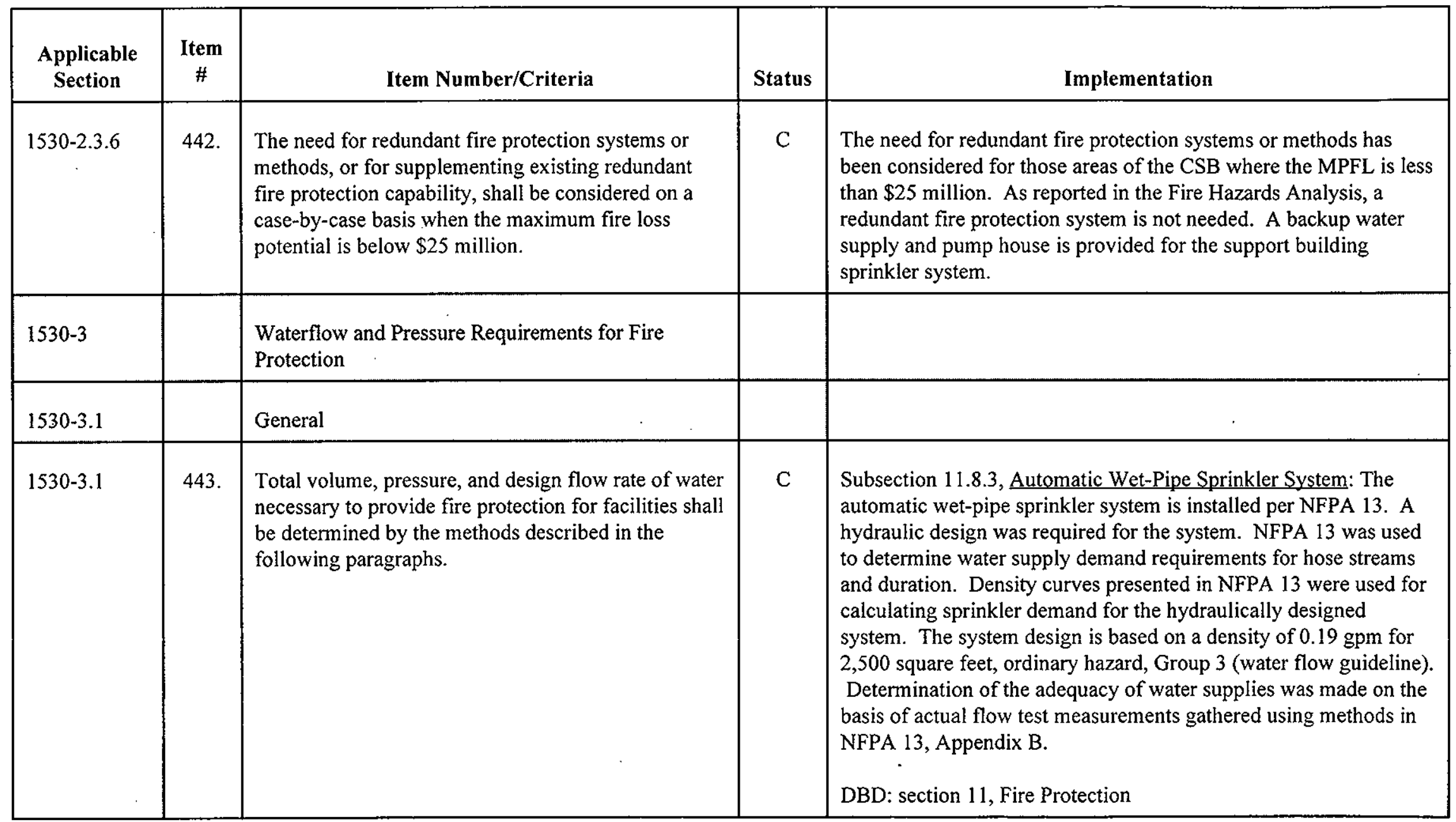




\section{Canister Storage Building Compliance Assessment DOE Order 6430.1A, General Design Criteria}

\begin{tabular}{|c|c|c|c|c|}
\hline $\begin{array}{l}\text { Applicable } \\
\text { Section }\end{array}$ & $\begin{array}{l}\text { Item } \\
\#\end{array}$ & Item Number/Criteria & Status & Implementation \\
\hline $1530-3.2$ & & Occupancy Hazard Classification & & \\
\hline $1530-3.2$ & 445. & $\begin{array}{l}\text { NFPA } 13 \text { shall be used to determine the Occupancy } \\
\text { Hazard Classification for any facility. Light hazard } \\
\text { occupancy rules are prohibited. }\end{array}$ & $\mathrm{C}$ & $\begin{array}{l}\text { Subsection 11.8.3, Automatic Wet-Pipe Sprinkler System: Light } \\
\text { hazard occupancy rules are not permitted for the design of this } \\
\text { system. Occupancy Hazard Classifications were established in } \\
\text { accordance with UBC as (H-7). This is in compliance with NFPA } \\
\text { 13. } \\
\text { DBD: section 11, Fire Protection }\end{array}$ \\
\hline $1530-3.3$ & & Water Demands for Sprinklered Facilities & & \\
\hline $1530-3.3 .1$ & & Schedule-Designed Sprinkler Systems & & \\
\hline $1530-3.3 .1$ & 446. & $\begin{array}{l}\text { For systems designed using schedule methods, NFPA } \\
13 \text { shall be used for calculating water demand in the } \\
\text { absence of specific requirements provided by } \\
\text { cognizant DOE fire protection authorities based on } \\
\text { unusual occupancies or special hazards. }\end{array}$ & NA & $\begin{array}{l}\text { Hydraulic design methodology was employed for the support } \\
\text { building sprinkler system. See statement } \# 443 \text {. }\end{array}$ \\
\hline
\end{tabular}




\section{Canister Storage Building Compliance Assessment DOE Order 6430.1A, General Design Criteria}

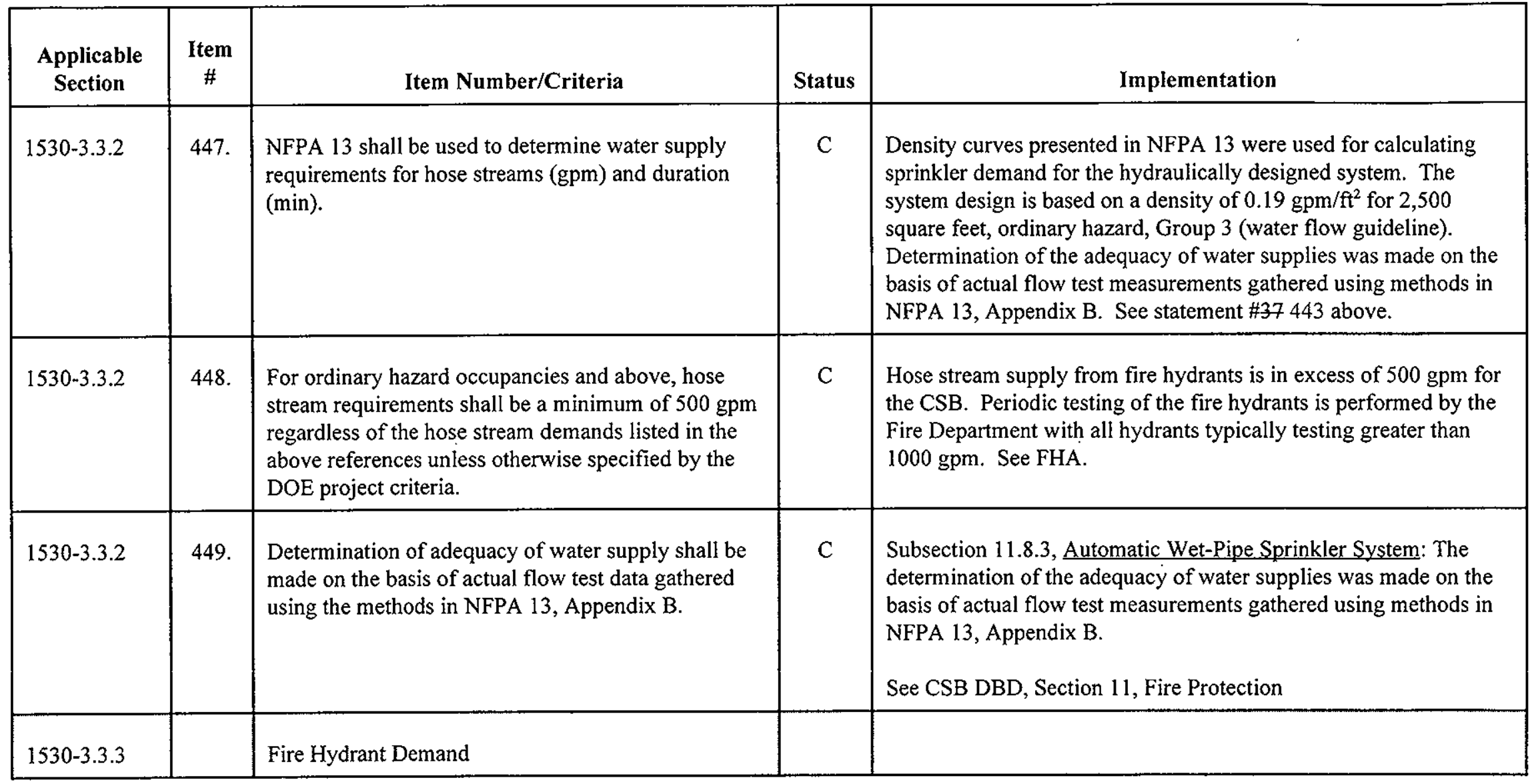




\section{Canister Storage Building Compliance Assessment \\ DOE Order 6430.1A, General Design Criteria}

HNF-4742, Rev. 0

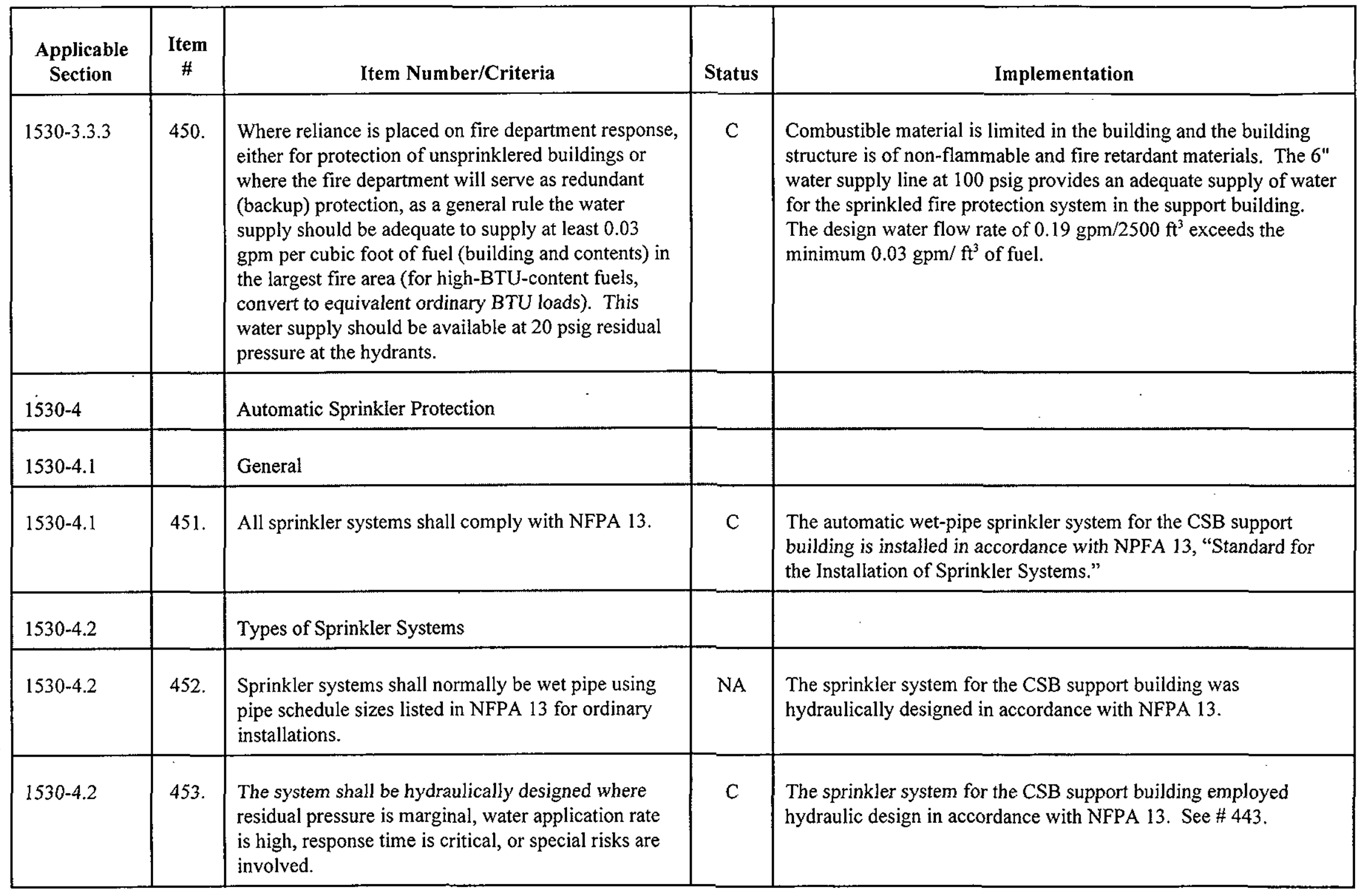




\section{Canister Storage Building Compliance Assessment DOE Order 6430.1A, General Design Criteria}

HNF-4742, Rev. 0

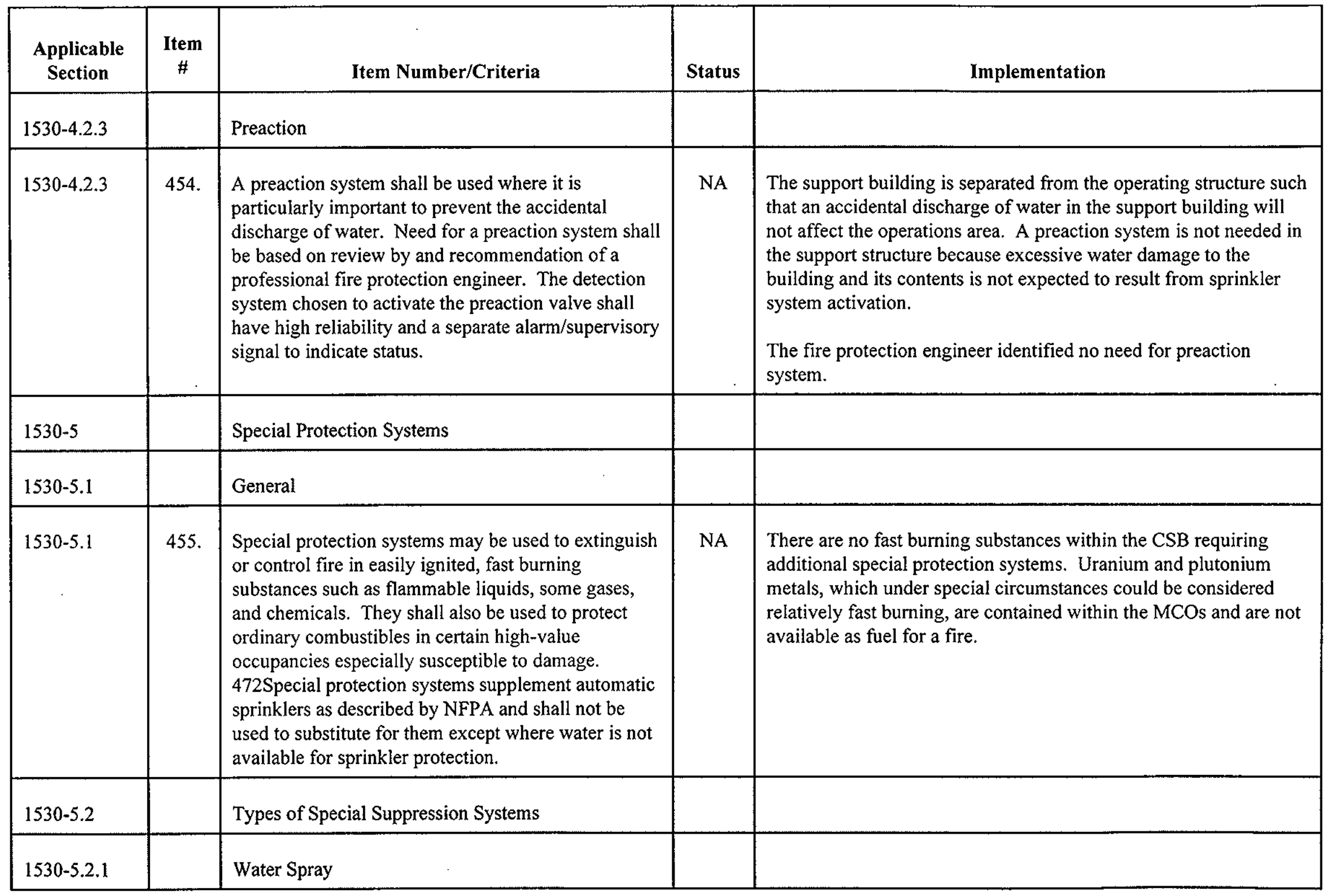




\section{Canister Storage Building Compliance Assessment \\ DOE Order 6430.1A, General Design Criteria}

HNF-4742, Rev. 0

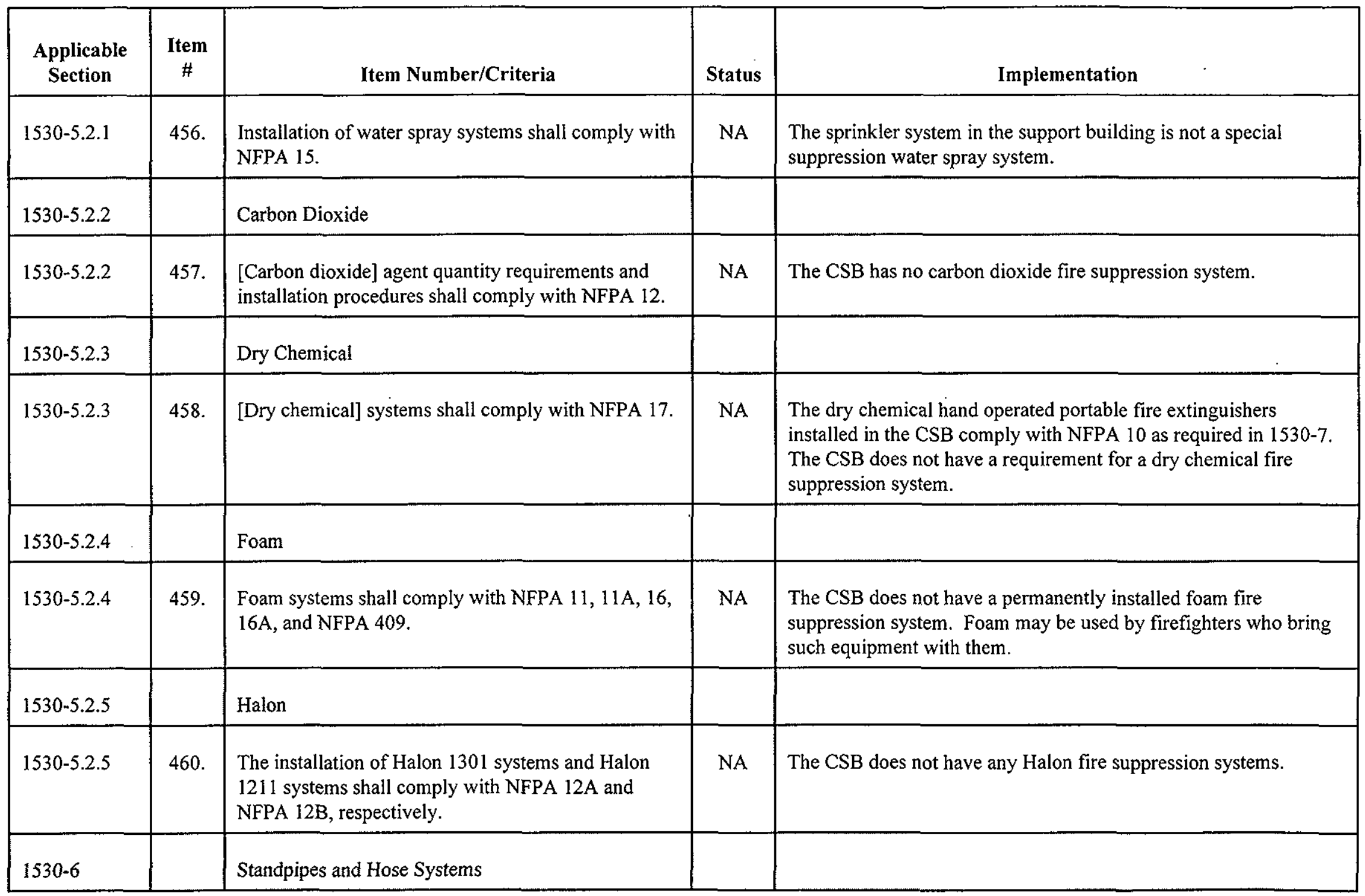




\section{Canister Storage Building Compliance Assessment \\ DOE Order 6430.1A, General Design Criteria}

HNF-4742, Rev. 0

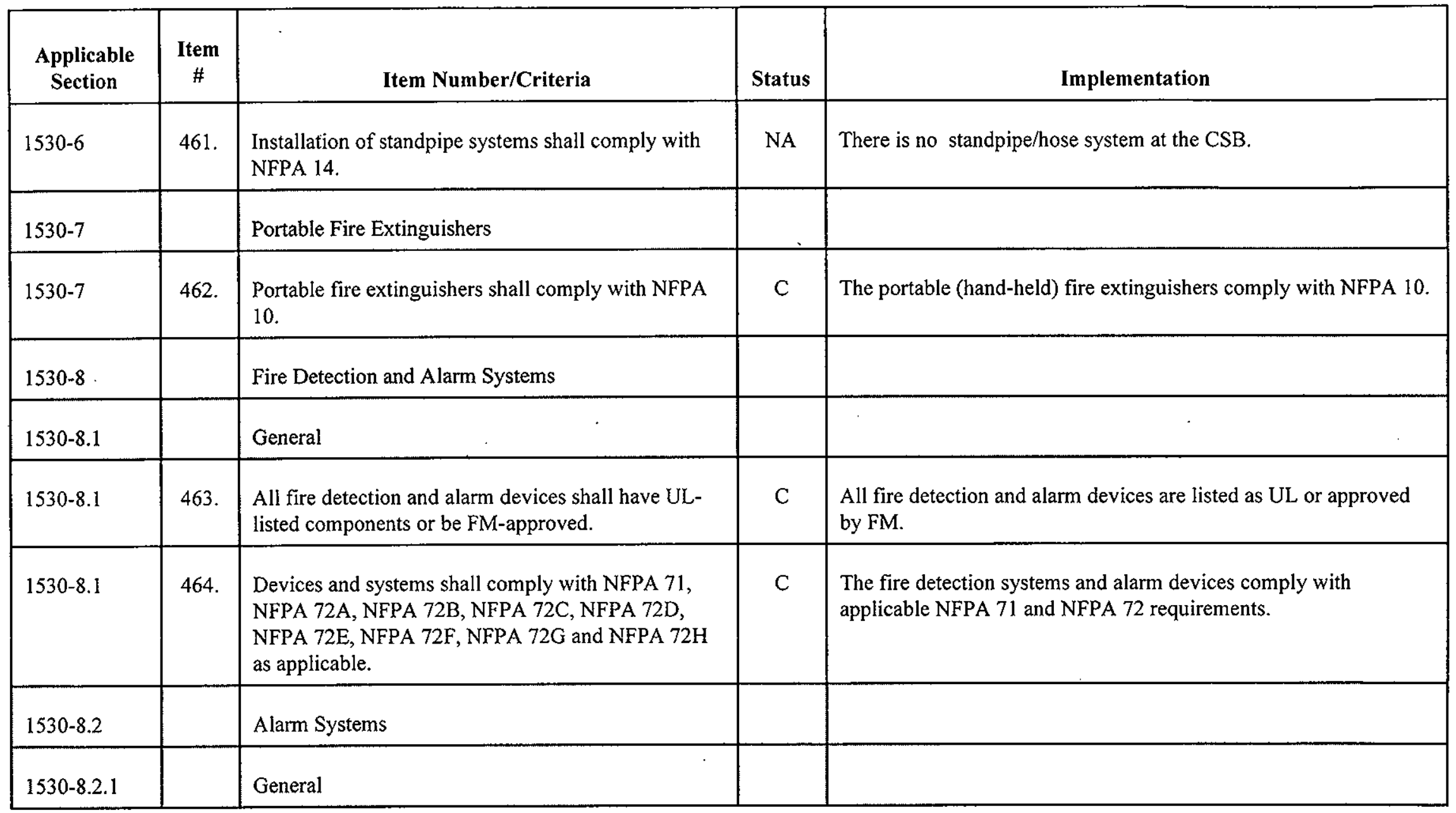




\section{Canister Storage Building Compliance Assessment \\ DOE Order 6430.1A, General Design Criteria}

HNF-4742, Rev. 0

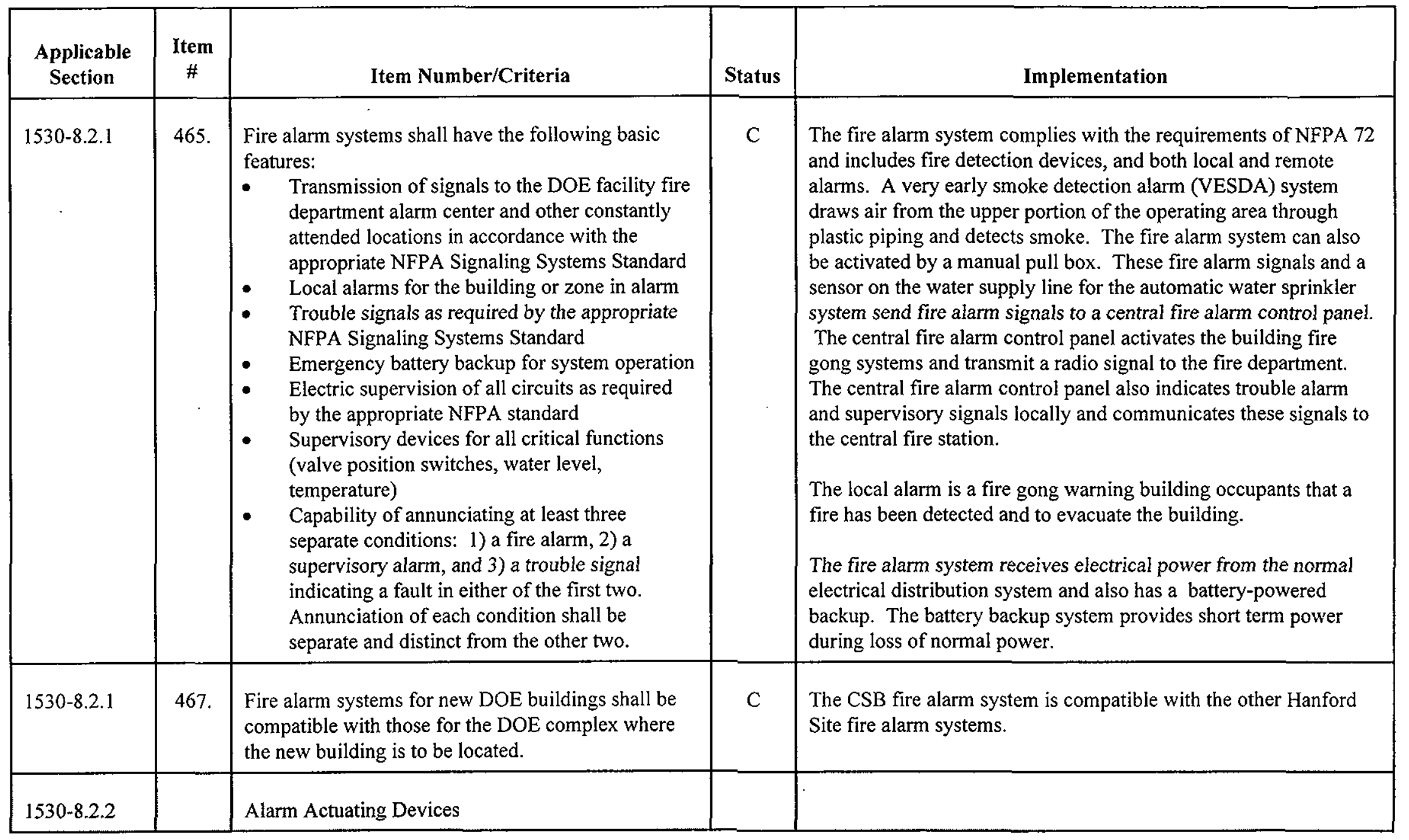




\section{Canister Storage Building Compliance Assessment \\ DOE Order 6430.1A, General Design Criteria}

HNF-4742, Rev. 0

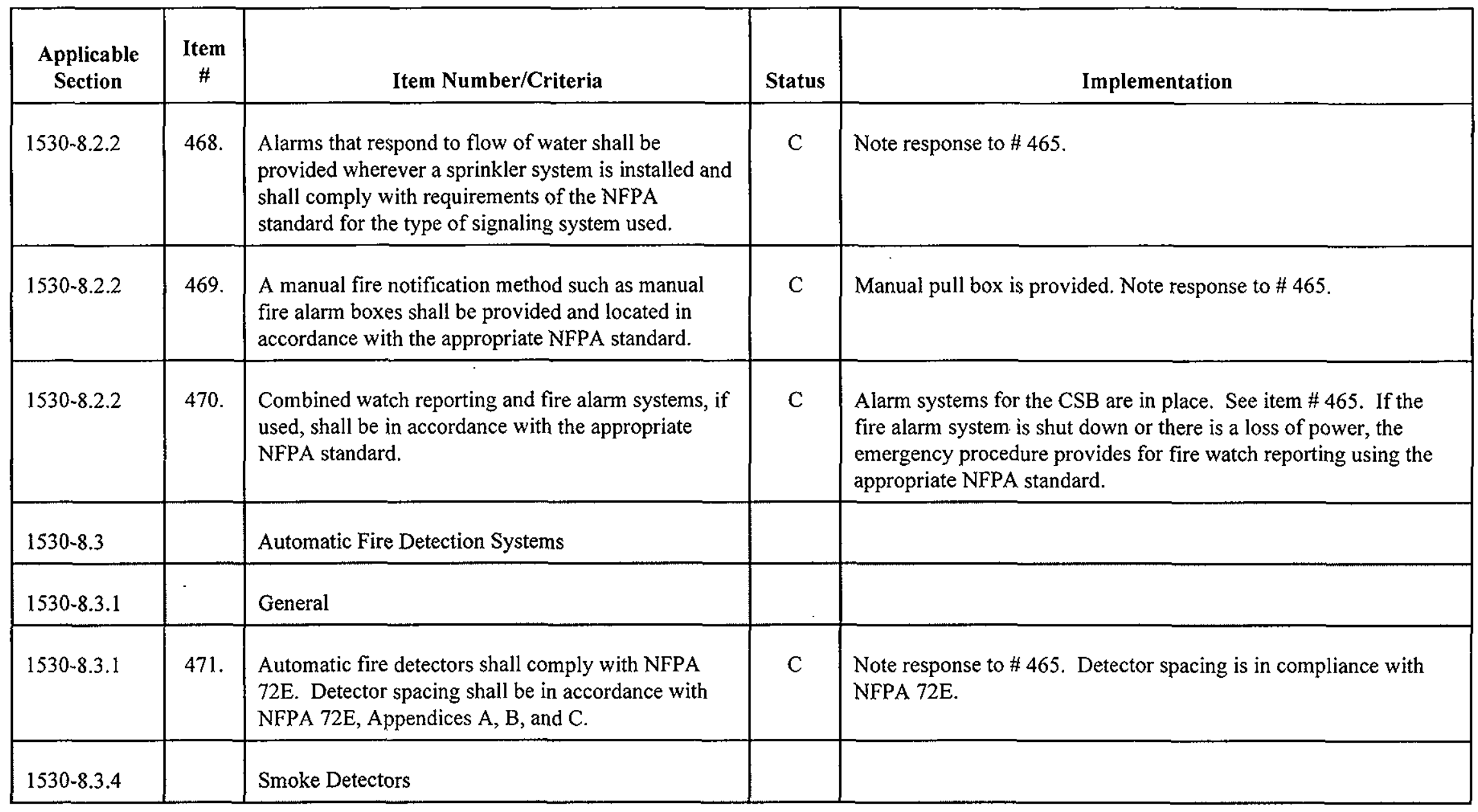




\section{Canister Storage Building Compliance Assessment DOE Order 6430.1A, General Design Criteria}

\begin{tabular}{|c|c|c|c|c|}
\hline $\begin{array}{l}\text { Applicable } \\
\text { Section }\end{array}$ & $\begin{array}{l}\text { Item } \\
\#\end{array}$ & Item Number/Criteria & Status & Implementation \\
\hline 1530.9 & & Water Storage and Distribution & & \\
\hline $1530-9$ & 474. & $\begin{array}{l}\text { Where automatic sprinkler systems or standpipes are } \\
\text { fed from a potable water system, approved check } \\
\text { valves shall be installed in sprinkler lead-ins to } \\
\text { preclude the introduction of pollutants from systems } \\
\text { or recirculation of stagnant water that would } \\
\text { contaminate the domestic water system. }\end{array}$ & NA & $\begin{array}{l}\text { The fire water supply line for the CSB uses water from the } 10^{\prime \prime} \text { fire } \\
\text { water main line; this is not connected to the potable water system. }\end{array}$ \\
\hline
\end{tabular}




\section{Canister Storage Building Compliance Assessment DOE Order 6430.1A, General Design Criteria}

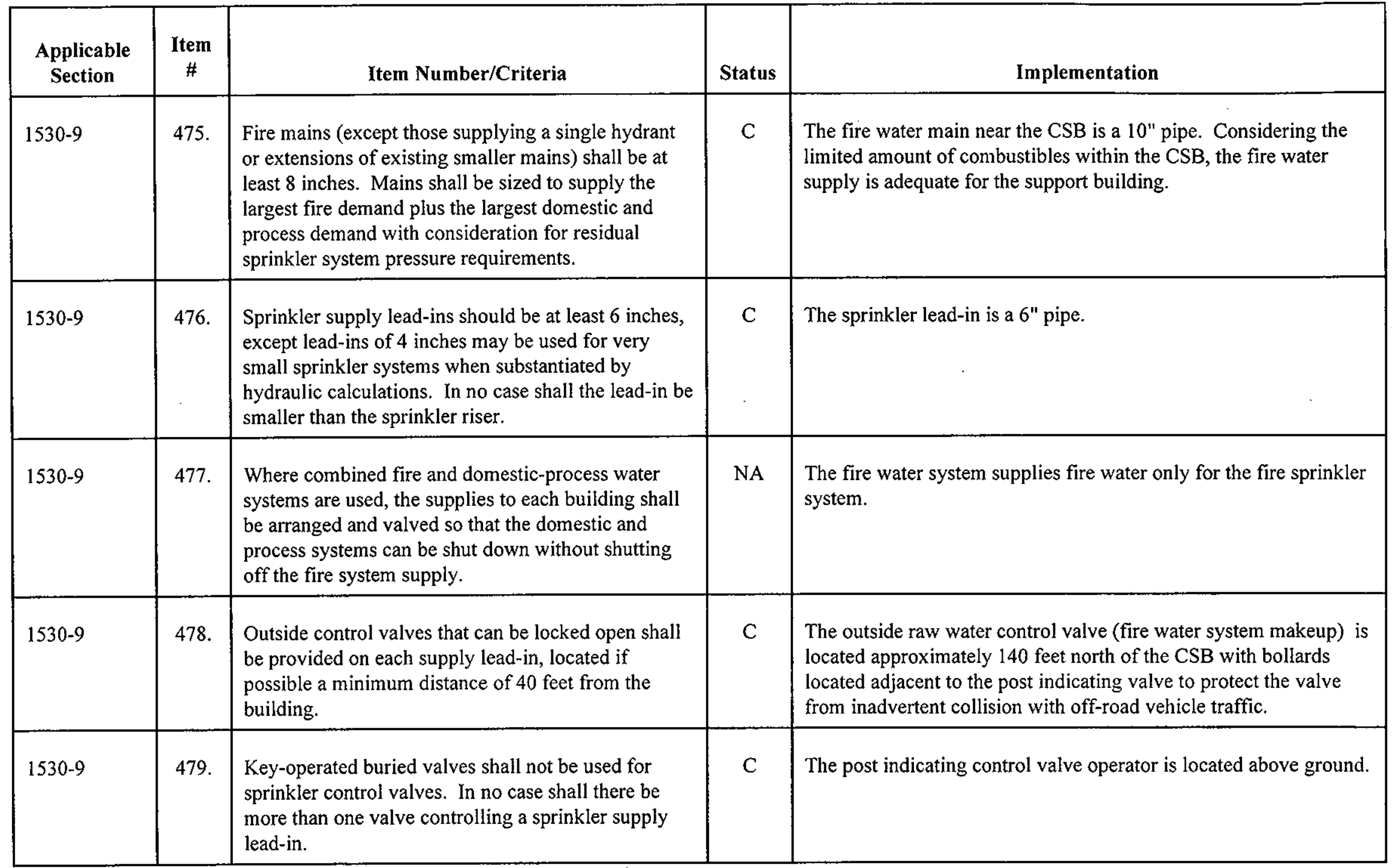




\section{Canister Storage Building Compliance Assessment DOE Order 6430.1A, General Design Criteria}

\begin{tabular}{|c|c|c|c|c|}
\hline $\begin{array}{l}\text { Applicable } \\
\text { Section }\end{array}$ & $\begin{array}{c}\text { Item } \\
\#\end{array}$ & Item Number/Criteria & Status & Implementation \\
\hline $1530-9$ & 480. & $\begin{array}{l}\text { All lead-ins shall be connected with the sprinkler } \\
\text { system at the base of the riser. Alarm valves shall be } \\
\text { located as close as practical to the building entry } \\
\text { point. }\end{array}$ & $\mathrm{C}$ & $\begin{array}{l}\text { The lead-in line is connected to the base of the control valve and } \\
\text { the alarm valve is located just inside the support building. }\end{array}$ \\
\hline $1530-9$ & 481. & $\begin{array}{l}\text { Hydrants shall be provided so that hose lays from } \\
\text { hydrants to all exterior portions of a protected } \\
\text { building are no more than } 300 \text { feet. Hydrants shall } \\
\text { not be closer to buildings than } 50 \text { feet. }\end{array}$ & $\mathrm{C}$ & $\begin{array}{l}\text { Three fire hydrants located near the CSB are between } 80 \text { and } 130 \\
\text { feet from the buildings. }\end{array}$ \\
\hline $1530-99$ & & Special Facilities & & . \\
\hline $1530-99.0$ & & General & & \\
\hline $1530-99.0$ & 482. & $\begin{array}{l}\text { An assessment shall be made early in the design or } \\
\text { modification to determine the facility structures, } \\
\text { systems, and components that shall be protected } \\
\text { against the effects of a DBF and explosion. }\end{array}$ & $\mathrm{C}$ & $\begin{array}{l}\text { A fire protection requirements assessment was made early in the } \\
\text { design of the CSB by a competent, experienced fire protection } \\
\text { engineer. The design that was built was based on that early } \\
\text { assessment. (Ref: CSB DBD, Section 11, Fire Protection). }\end{array}$ \\
\hline $1530-99.0$ & 483. & $\begin{array}{l}\text { A fire protection engineer or person knowledgeable } \\
\text { in applying the principles of fire protection shall } \\
\text { develop the fire protection system. }\end{array}$ & $\mathrm{C}$ & $\begin{array}{l}\text { Knowledgeable fire protection engineers from WHC, FDI, ARES, } \\
\text { and Hughes Associates, developed the fire protection system. The } \\
\text { fire protection design was reviewed by the Hanford Fire Marshall. } \\
\text { See item \# } 437 \text {. }\end{array}$ \\
\hline
\end{tabular}




\section{Canister Storage Building Compliance Assessment \\ DOE Order 6430.1A, General Design Criteria}

HNF-4742, Rev. 0

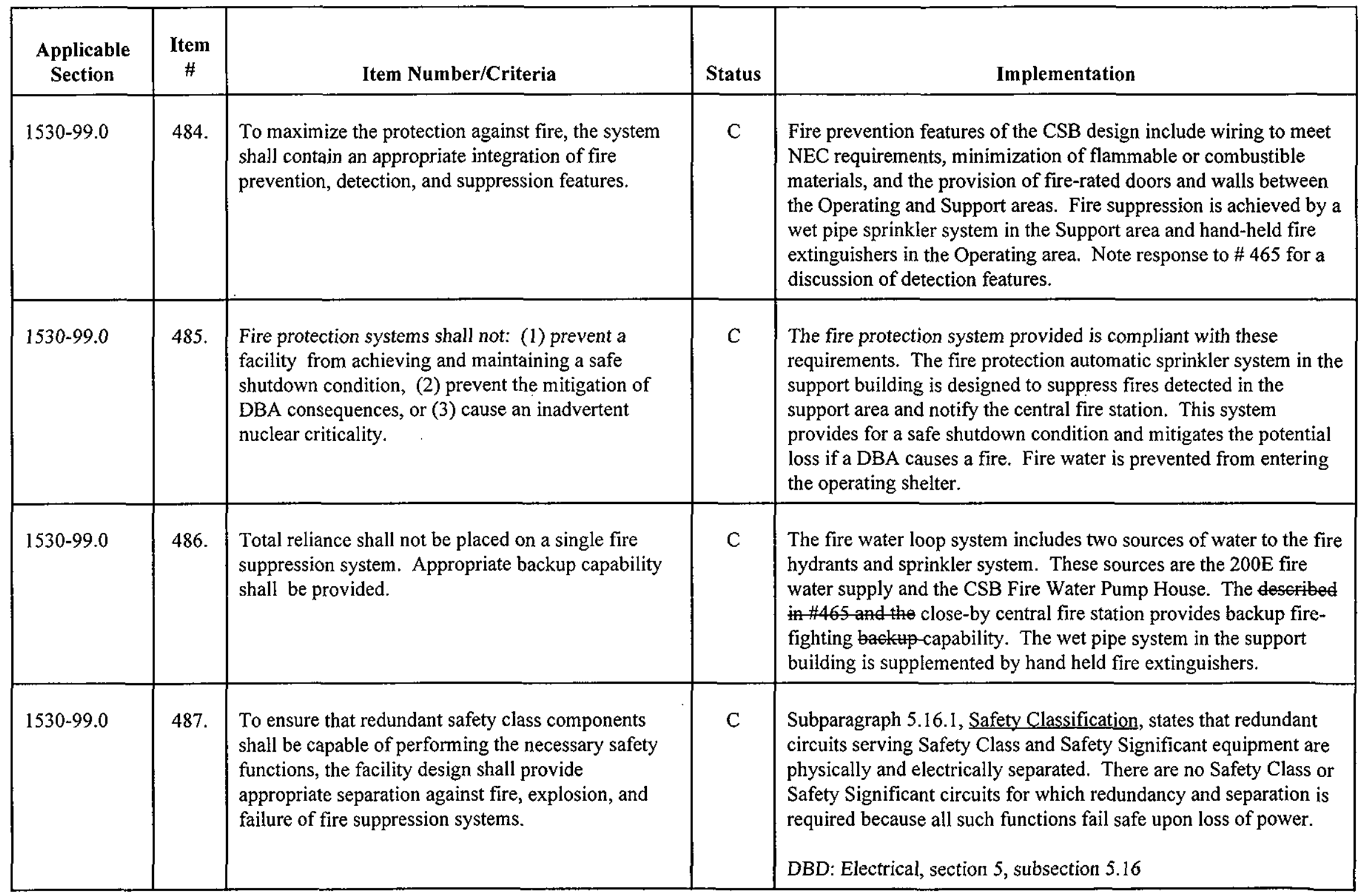




\section{Canister Storage Building Compliance Assessment DOE Order 6430.1A, General Design Criteria}

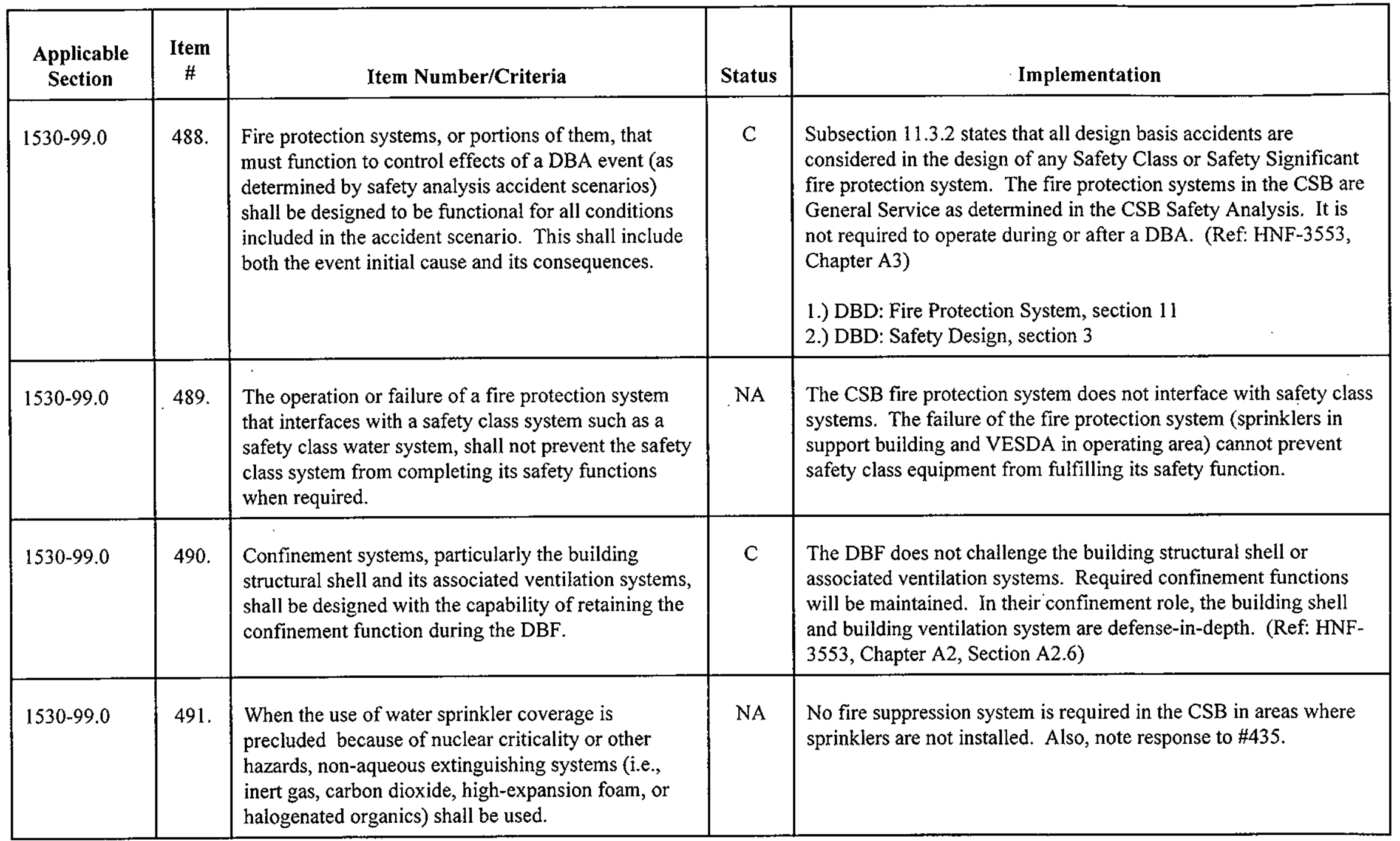




\section{Canister Storage Building Compliance Assessment DOE Order 6430.1A, General Design Criteria}

\begin{tabular}{|c|c|c|c|c|}
\hline $1530-99.0$ & 493. & $\begin{array}{l}\text { Fire protection systems and components shall have } \\
\text { fail safe features and audible and visual alarms for } \\
\text { operability and trouble indications. }\end{array}$ & $\mathrm{C}$ & $\begin{array}{l}\text { Appropriate alarms and trouble indicators are provided with the } \\
\text { systems. Note response to } \# 465 \text {. }\end{array}$ \\
\hline $1530-99.0$ & 494. & $\begin{array}{l}\text { An emergency source of electric power shall be } \\
\text { provided to operate fire protection systems. Fire } \\
\text { protection systems shall be capable of operating } \\
\text { during a normal power outage. The emergency } \\
\text { power sources and the electrical distribution circuits } \\
\text { shall have independence and testability to ensure } \\
\text { performance of their safety functions assuming any } \\
\text { single failure. }\end{array}$ & $\mathrm{C}$ & $\begin{array}{l}\text { The fire protection system is General Service. The fire protection } \\
\text { system is supported by a battery backup power system so that it } \\
\text { remains functional in the event of a power failure for up to } 48 \\
\text { hours. The battery backup is not "emergency power" in the safety } \\
\text { class sense. }\end{array}$ \\
\hline $1530-99.0$ & 495. & $\begin{array}{l}\text { The designers of the fire protection system shall } \\
\text { consider the fire and explosion potential of the } \\
\text { materials being processed and the solvents used } \\
\text { during processing. In addition, the design shall } \\
\text { include facility-specific fire protection systems to } \\
\text { mitigate the damage from pyrophoric and other } \\
\text { materials that are fire hazards, (e.g., magnesium, ion } \\
\text { exchange resins, nitrate solvent and nitrate reduction } \\
\text { reactions, and zirconium fuel element cladding } \\
\text { hulls). }\end{array}$ & $\mathrm{C}$ & $\begin{array}{l}\text { The FHA addresses potential sources of fire in the CSB. The CSB } \\
\text { contains no unusual fire hazards requiring special fire protection } \\
\text { systems beyond the sprinkler system for the support building and } \\
\text { the VESDA for the operating area. } \\
\text { No processing takes place in the CSB operations. Uranium metal, } \\
\text { which under special circumstances could be considered pyrophoric } \\
\text { is contained within the sealed MCO and is not available for a fire } \\
\text { as fuel. }\end{array}$ \\
\hline
\end{tabular}




\section{Canister Storage Building Compliance Assessment DOE Order 6430.1A, General Design Criteria}

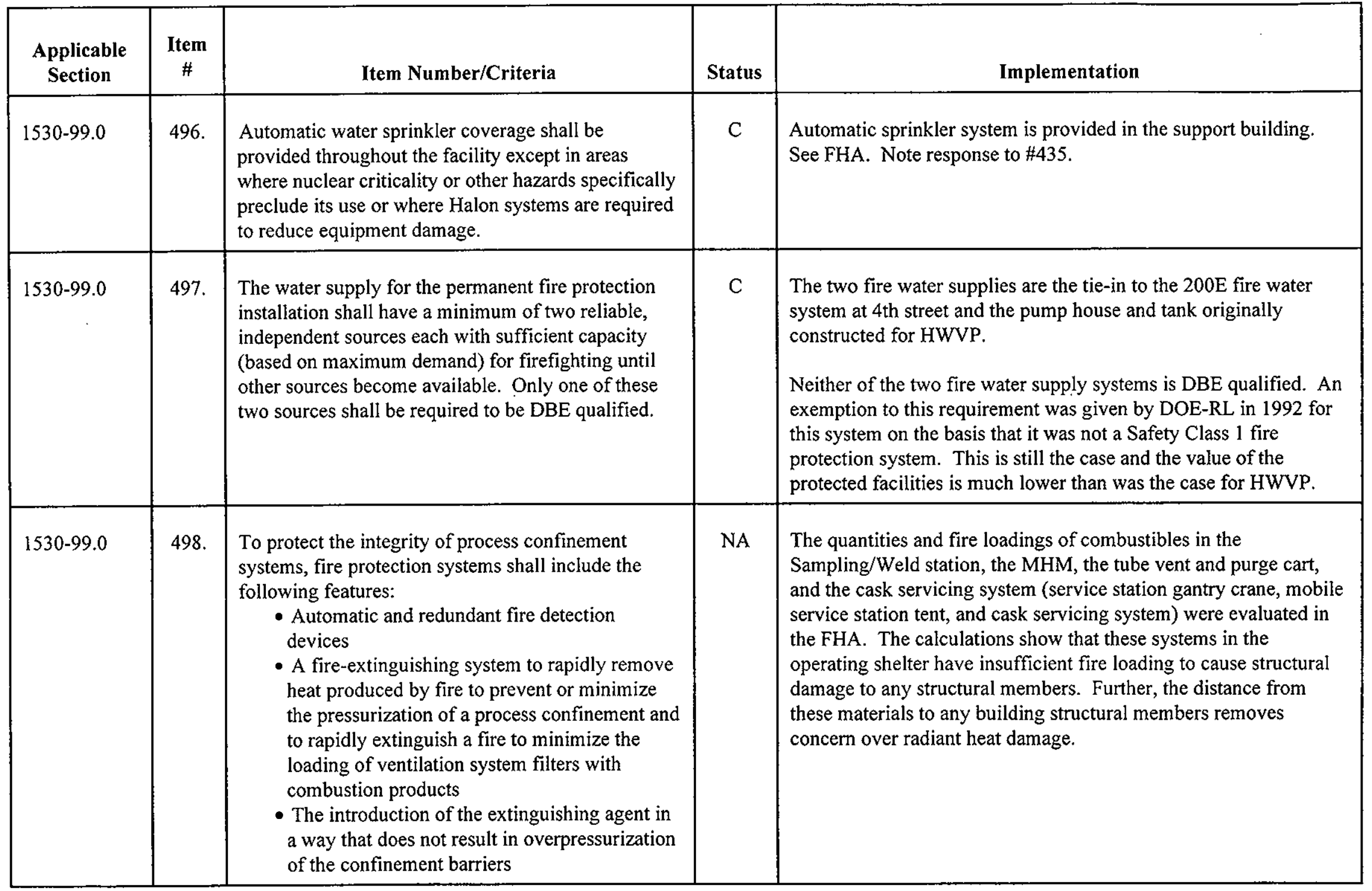




\section{Canister Storage Building Compliance Assessment DOE Order 6430.1A, General Design Criteria}

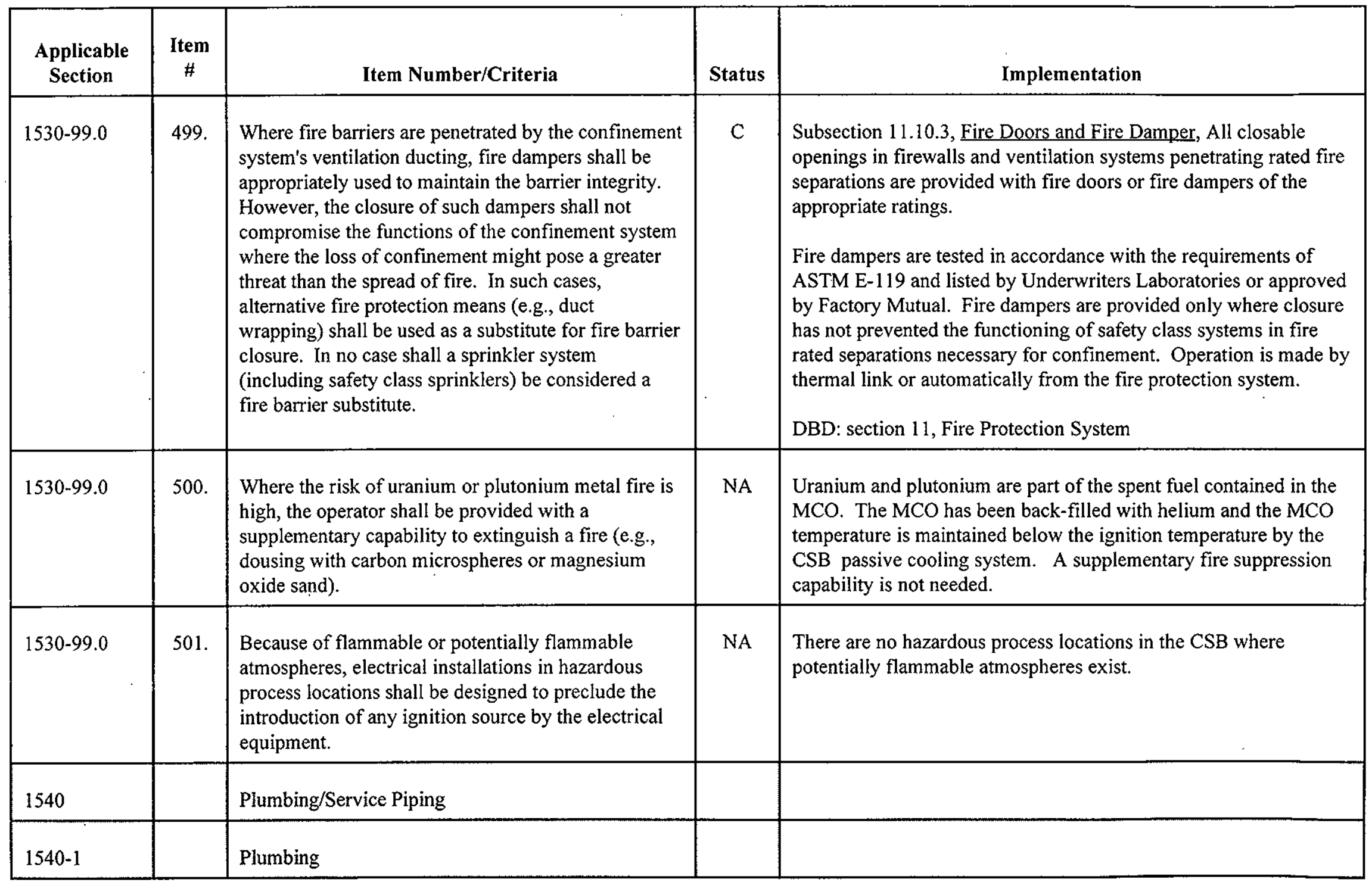




\section{Canister Storage Building Compliance Assessment \\ DOE Order 6430.1A, General Design Criteria}

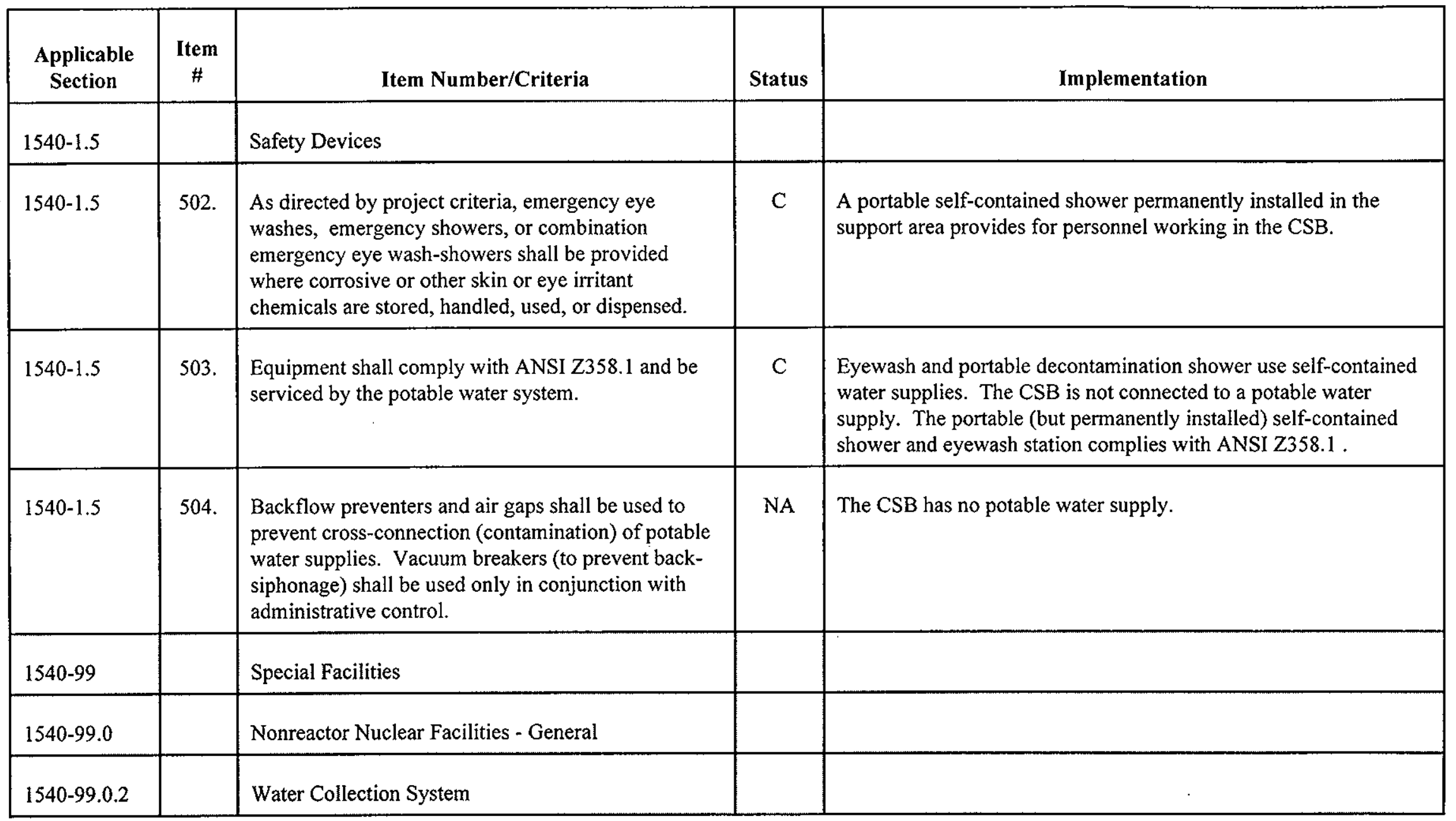




\section{Canister Storage Building Compliance Assessment DOE Order 6430.1A, General Design Criteria}

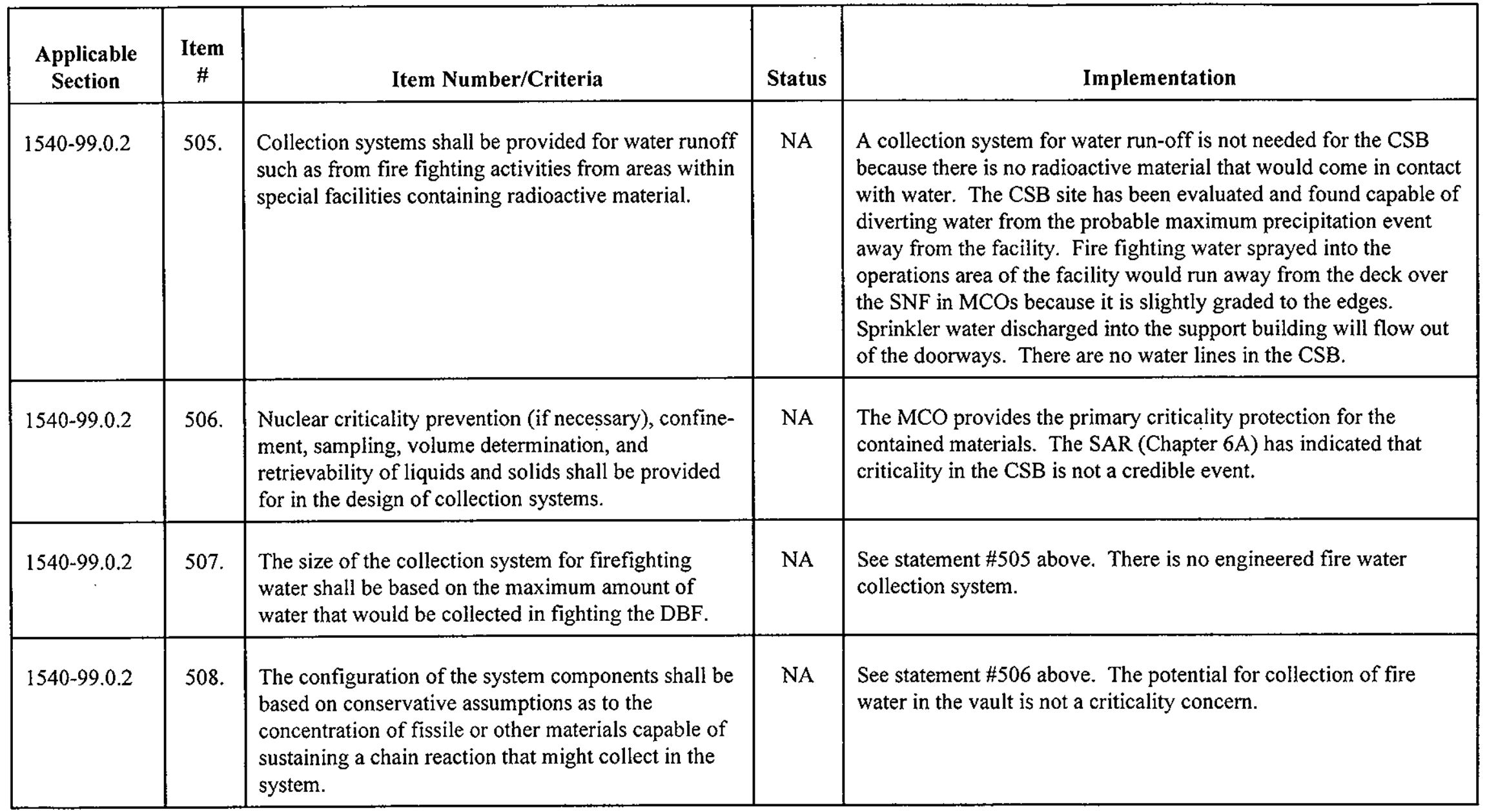




\section{Canister Storage Building Compliance Assessment DOE Order 6430.1A, General Design Criteria}

HNF-4742, Rev. 0

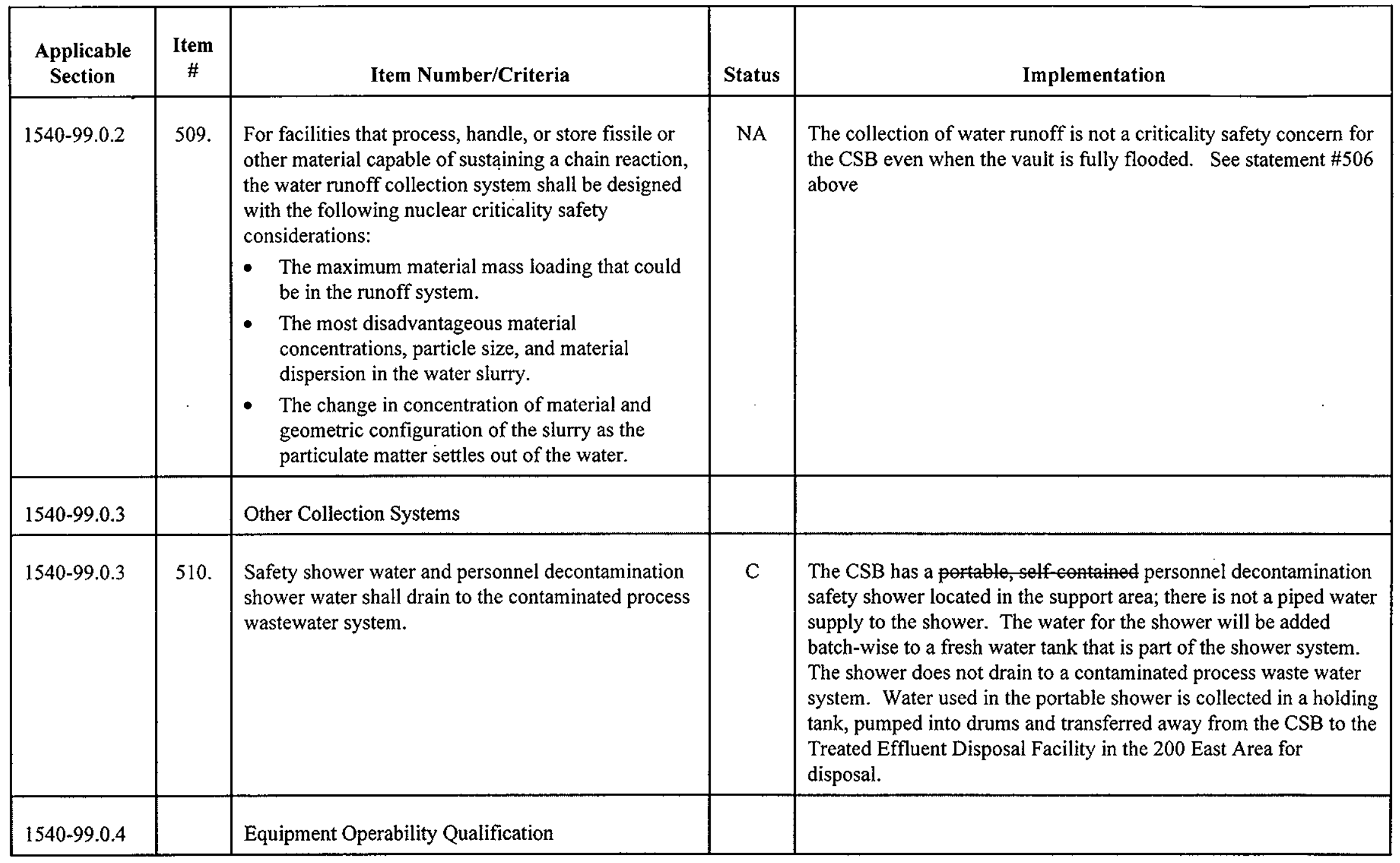




\section{Canister Storage Building Compliance Assessment \\ DOE Order 6430.1A, General Design Criteria}

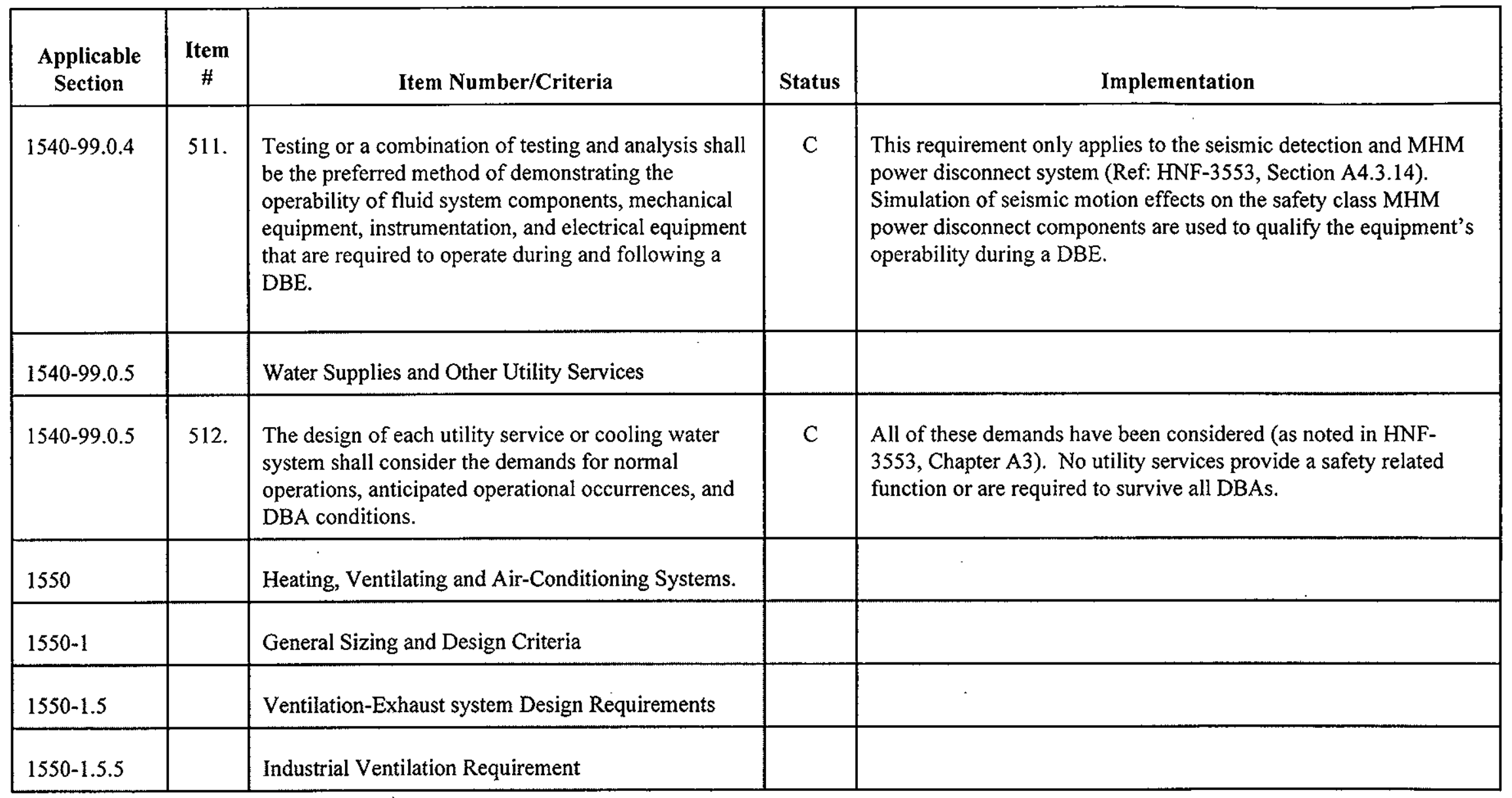




\section{Canister Storage Building Compliance Assessment DOE Order 6430.1A, General Design Criteria}

\begin{tabular}{|c|c|c|c|c|}
\hline $\begin{array}{l}\text { Applicable } \\
\text { Section }\end{array}$ & $\begin{array}{c}\text { Item } \\
\#\end{array}$ & Item Number/Criteria & Status & Implementation \\
\hline $1550-1.5 .5$ & 514. & $\begin{array}{l}\text { Design air quantities and transport velocities shall be } \\
\text { calculated according to the calculation methods } \\
\text { prescribed by the ASHRAE Systems handbook, the } \\
\text { ASHRAE Application handbook, the ACGIH } \\
\text { Industrial Ventilation Manual, } 29 \text { CFR 1910, and } \\
\text { NFPA } 45 \text {. }\end{array}$ & $\mathrm{C}$ & $\begin{array}{l}\text { The CSB HVAC system is classified as general service because no } \\
\text { known or expected radiological or toxicological wastes are } \\
\text { mitigated by the HVAC system. The HVAC system functions by } \\
\text { drawing air inward from outside the building to sweep any } \\
\text { potential contaminants into the HVAC discharge HEPA filters for } \\
\text { containment. } \\
\text { The system has been designed to meet ASHRAE } 62 \text { indoor air } \\
\text { quality standards, } 29 \text { CFR } 1910 \text {, and NFPA } 45 \text { standards (fire } \\
\text { protection for laboratories using chemicals), and also meets } \\
\text { ACGIH requirements. }\end{array}$ \\
\hline $1550-1.5 .5$ & 515. & $\begin{array}{l}\text { Makeup air shall be provided in the quantities } \\
\text { required to maintain required positive or negative } \\
\text { room static pressure requirements and to offset local } \\
\text { exhaust air quantities. Makeup air shall be tempered. }\end{array}$ & $\mathrm{C}$ & $\begin{array}{l}\text { The CSB HVAC system draws outside air through filtered air } \\
\text { handlers where the air is cooled in the summer time and heated in } \\
\text { the winter time to maintain a comfortable working environment in } \\
\text { all areas of the facility. The support area is maintained at a } \\
\text { positive pressure with respect to the operating area for confinement } \\
\text { of potential hazardous airborne contaminants. }\end{array}$ \\
\hline $1550-1.5 .6$ & & Local Exhaust Systems & & \\
\hline
\end{tabular}




\section{Canister Storage Building Compliance Assessment DOE Order 6430.1A, General Design Criteria}

HNF-4742, Rev. 0

\begin{tabular}{|c|c|c|c|c|}
\hline $\begin{array}{l}\text { Applicable } \\
\text { Section }\end{array}$ & $\begin{array}{l}\text { Item } \\
\#\end{array}$ & Item Number/Criteria & Status & Implementation \\
\hline $1550-1.5 .6$ & 516. & $\begin{array}{l}\text { Local exhaust systems shall be designed to maintain } \\
\text { the required capture air velocities for source } \\
\text { containment control. Air quantities and transport } \\
\text { shall be calculated based on the calculation methods } \\
\text { prescribed by the ASHRAE systems handbook, the } \\
\text { ASHRAE Applications handbook and the ACGIH } \\
\text { Industrial Ventilation Manual. }\end{array}$ & $\mathrm{C}$ & $\begin{array}{l}\text { Local exhaust systems (tent enclosure, and sample and weld } \\
\text { hoods) are designed to maintain the required capture air velocities } \\
\text { for source containment control. Note response to } \# 514 \text {. }\end{array}$ \\
\hline $1550-1.5 .7$ & & Equipment Room Ventilation & & \\
\hline $1550-1.5 .7$ & 517. & $\begin{array}{l}\text { Mechanical and electrical equipment rooms shall be } \\
\text { exhausted so that room temperature does not exceed } \\
\text { NEMA equipment ratings. DOE project criteria shall } \\
\text { provide the space temperature limit criterion. Where } \\
\text { mechanical ventilation cannot maintain a satisfactory } \\
\text { environment, evaporative cooling systems or other } \\
\text { mechanical cooling systems shall be provided. }\end{array}$ & $\mathrm{C}$ & $\begin{array}{l}\text { The CSB mechanical and electrical equipment rooms are provided } \\
\text { with HVAC. The Design Basis Document (DBD) references HPS- } \\
\text { SDC-5.1 for recommended temperature and humidity limits. The } \\
\text { exhaust design for the equipment rooms is based on maintaining } \\
\text { temperatures below levels that challenge NEMA equipment } \\
\text { ratings. Evaporative cooling is not required. The temperature } \\
\text { control range for these rooms is } 55 \mathrm{~F} \text { to } 95 \mathrm{~F} \text {. NEMA equipment } \\
\text { temperature range for sensitive electronic equipment is } 58 \mathrm{~F} \text { to } \\
104 \mathrm{~F} \text {. A review of the installed equipment shows that there are no } \\
\text { instruments/equipment in the CSB that would be effected with a } \\
\text { room temperature of } 55 \mathrm{~F} \text {. Note response to \# } 515 \text {. }\end{array}$ \\
\hline $1550-2$ & & $\begin{array}{l}\text { Heating, Ventilation, and Air-Conditioning Systems } \\
\text { Selection }\end{array}$ & & . \\
\hline $1550-2.5$ & & Air Handling and air Distribution Systems & & \\
\hline $1550-2.5 .5$ & & Air Cleaning Devices & & \\
\hline $1550-2.5 .5$ & & High-Efficiency Particulate Air Filters & & \\
\hline
\end{tabular}




\section{Canister Storage Building Compliance Assessment DOE Order 6430.1A, General Design Criteria}

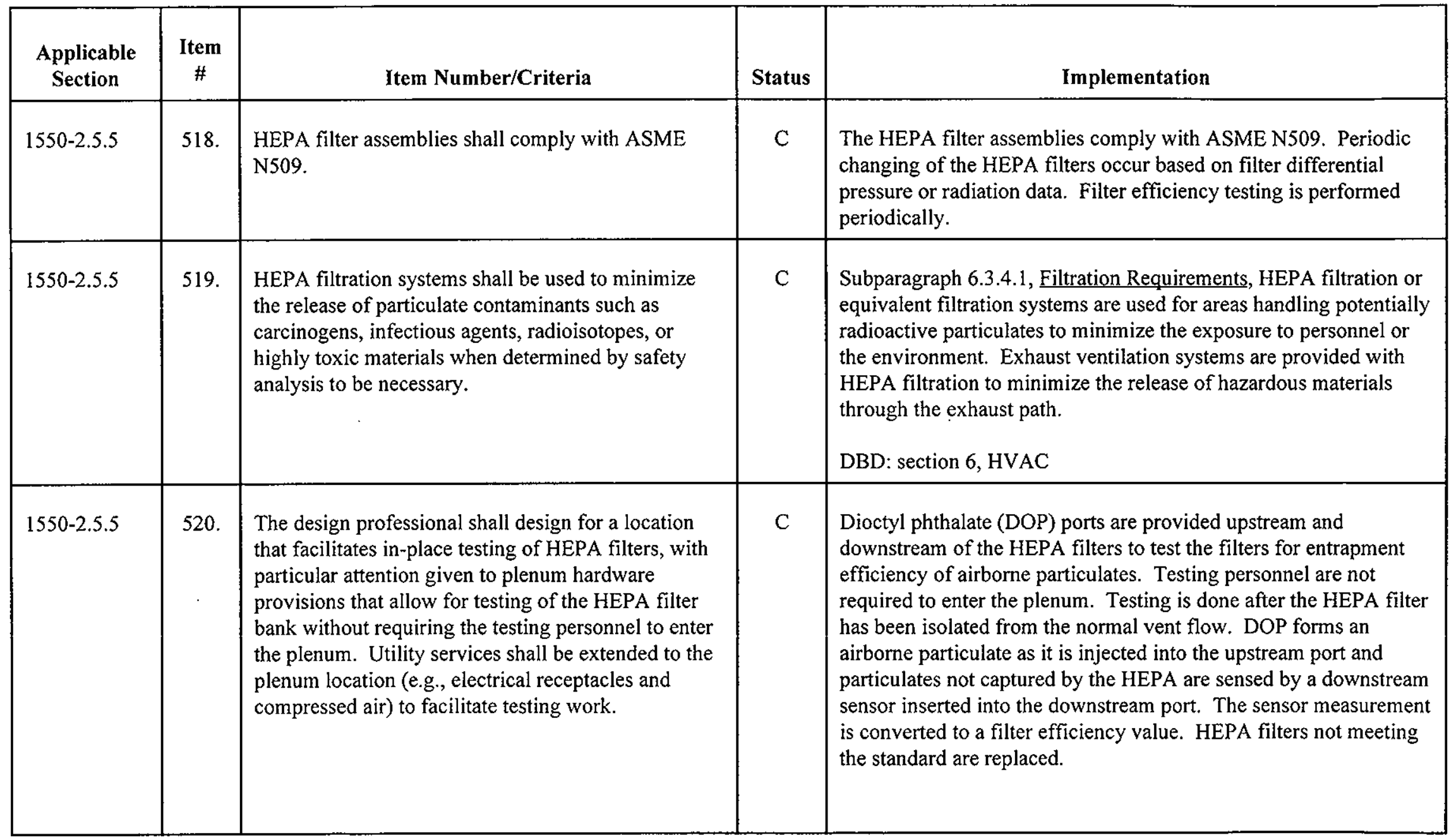




\section{Canister Storage Building Compliance Assessment DOE Order 6430.1A, General Design Criteria}

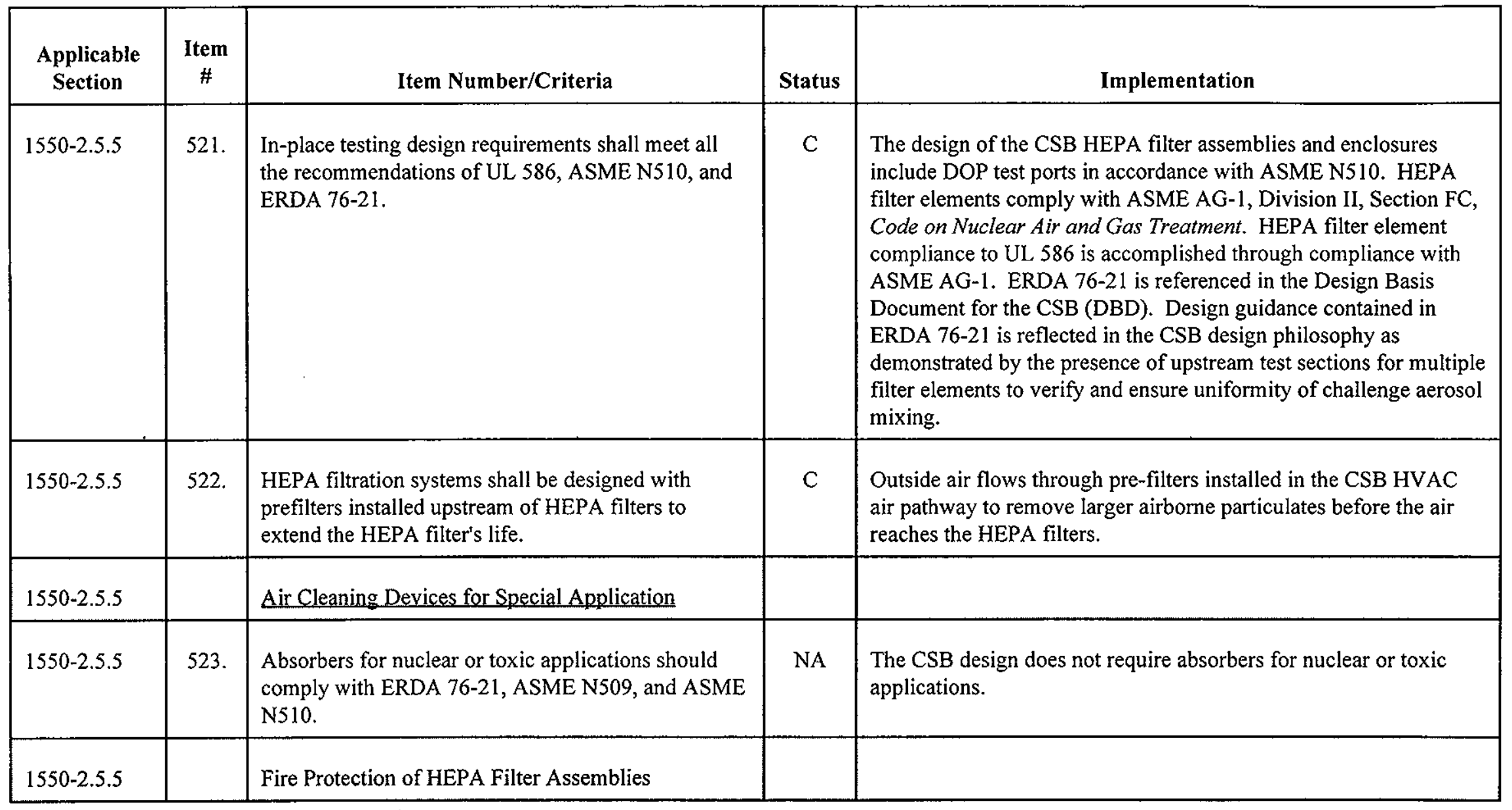




\section{Canister Storage Building Compliance Assessment DOE Order 6430.1A, General Design Criteria}

\begin{tabular}{|c|c|c|c|c|}
\hline $\begin{array}{l}\text { Applicable } \\
\text { Section }\end{array}$ & $\begin{array}{c}\text { Item } \\
\#\end{array}$ & Item Number/Criteria & Status & Implementation \\
\hline $1550-2.5 .5$ & 525. & $\begin{array}{l}\text { The HEPA filter fire protection system shall be } \\
\text { activated in a manner consistent with the fire } \\
\text { protection system in the room or building in which } \\
\text { the filters are located and as directed by the } \\
\text { cognizant DOE fire protection authority. }\end{array}$ & $\mathrm{C}$ & $\begin{array}{l}\text { Automatic, fusible-link fire dampers and duct-mounted smoke } \\
\text { detectors provide for worker safety. Fire dampers are spring- } \\
\text { loaded, duct-mounted collapsible dampers that automatically } \\
\text { extend and seal off the HVAC ducts when the air temperature } \\
\text { melts the fusible link. Fire dampers and smoke detectors are } \\
\text { placed to alert operators of a fire, send a fire alarm signal to the } \\
\text { central fire station and to limit air flows. These controls minimize } \\
\text { air flow to the fire. The operating area, during a fire, is maintained } \\
\text { at a negative pressure with respect to the support area and the } \\
\text { outside atmosphere. }\end{array}$ \\
\hline $1550-2.5 .6$ & & Ductwork Systems & & \\
\hline $1550-2.5 .6$ & 526. & $\begin{array}{l}\text { Ductwork systems shall be designed to meet the } \\
\text { leakage rate requirements of SMACNA HVAC Air } \\
\text { Duct Leakage Test Manual. }\end{array}$ & $\mathrm{C}$ & $\begin{array}{l}\text { HVAC ductwork for the CSB is designed to meet SMACNA } \\
\text { leakage requirements. (Ref: HNF-3553, Section A2.7.2). } \\
\text { CSB Specification Section 15840, Ductwork and Accessories }\end{array}$ \\
\hline
\end{tabular}




\section{Canister Storage Building Compliance Assessment DOE Order 6430.1A, General Design Criteria}

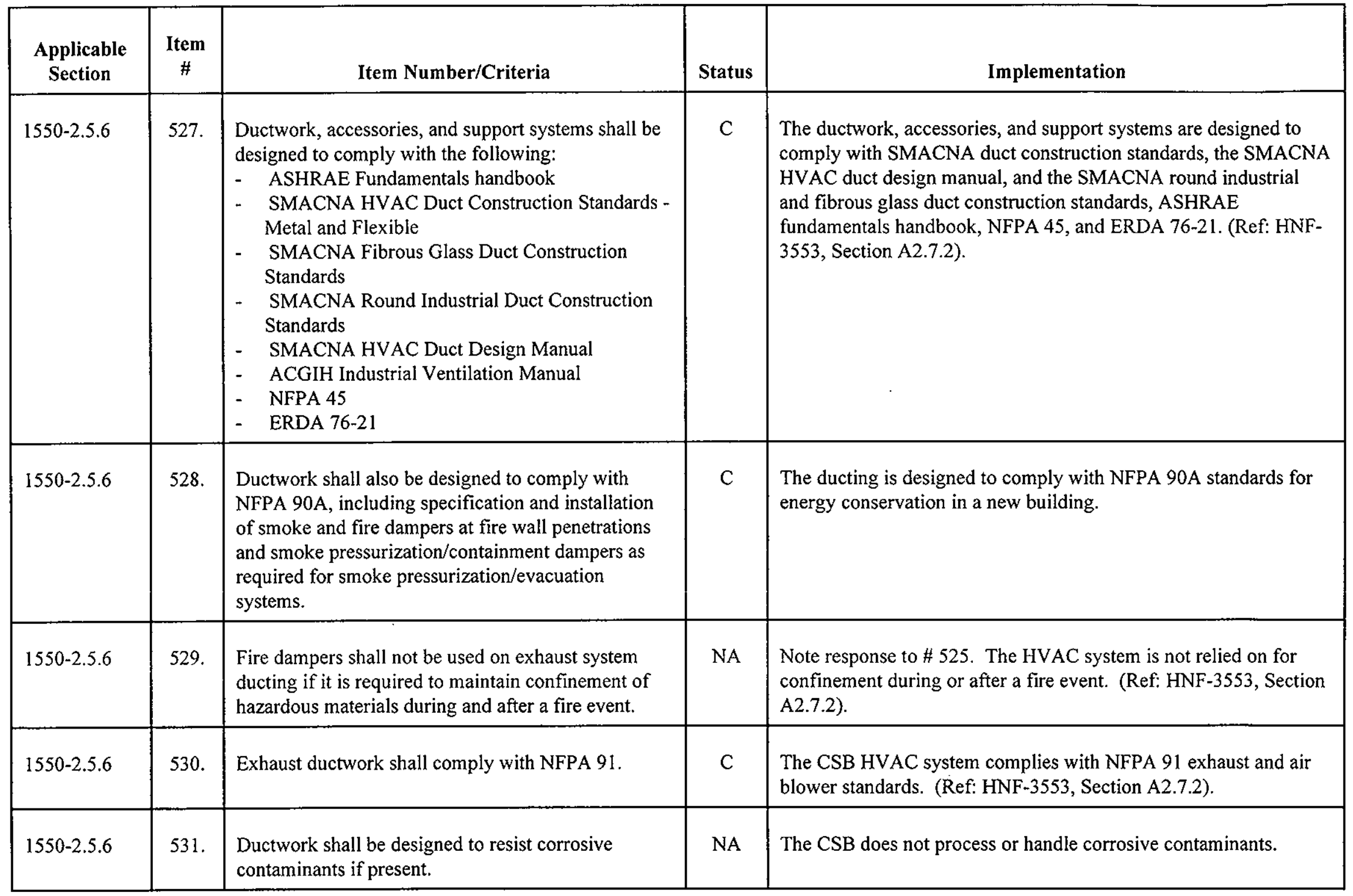




\section{Canister Storage Building Compliance Assessment DOE Order 6430.1A, General Design Criteria}

HNF-4742, Rev. 0

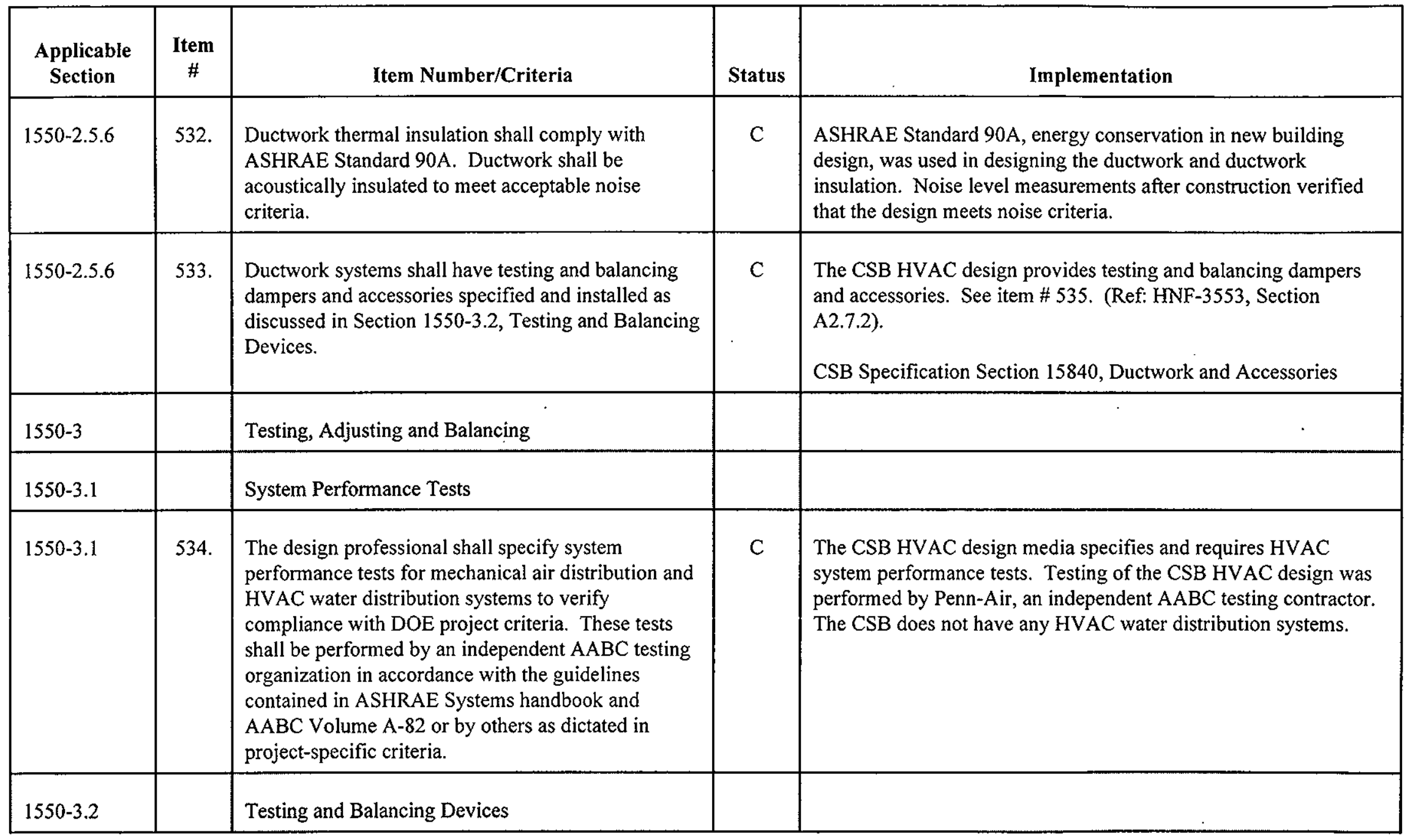




\section{Canister Storage Building Compliance Assessment DOE Order 6430.1A, General Design Criteria}

HNF-4742, Rev. 0

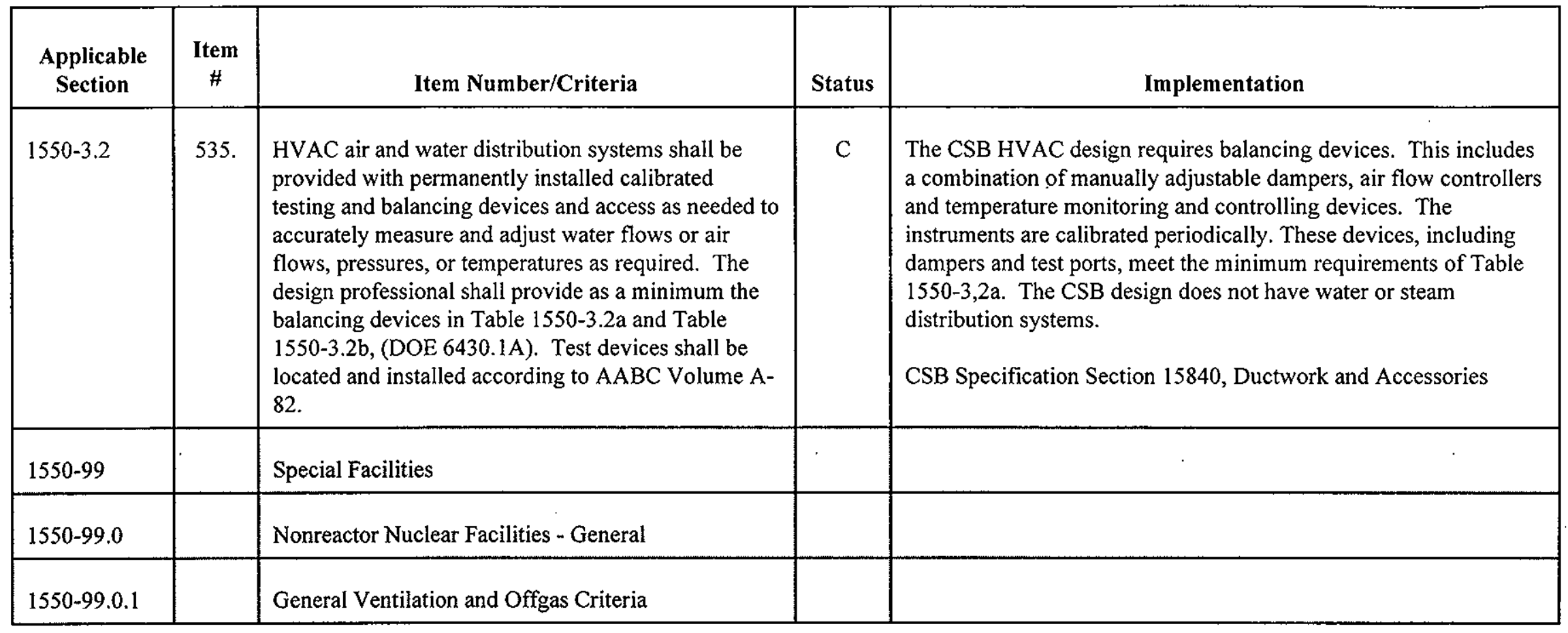




\section{Canister Storage Building Compliance Assessment \\ DOE Order 6430.1A, General Design Criteria}

HNF-4742, Rev. 0

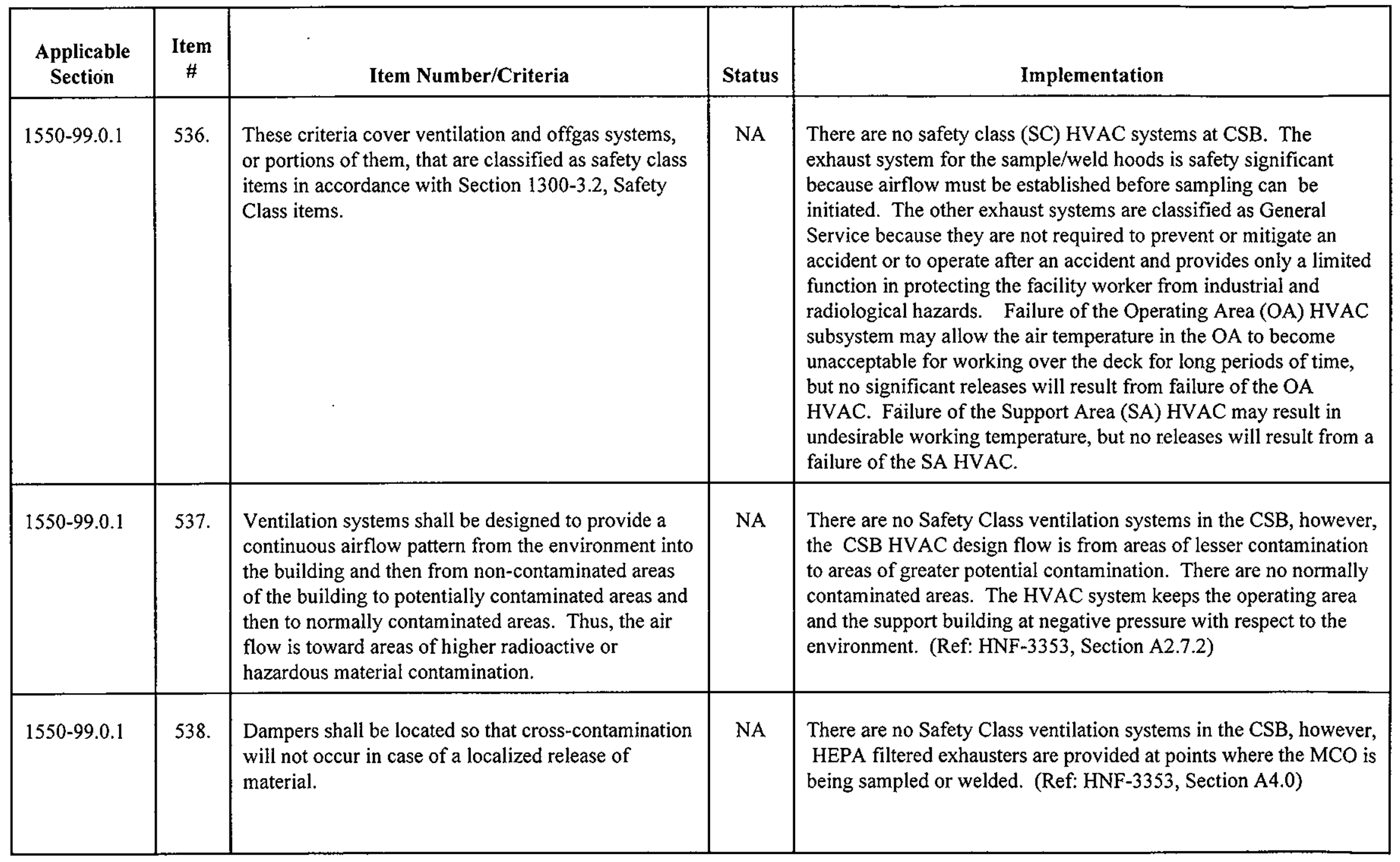




\section{Canister Storage Building Compliance Assessment DOE Order 6430.1A, General Design Criteria}

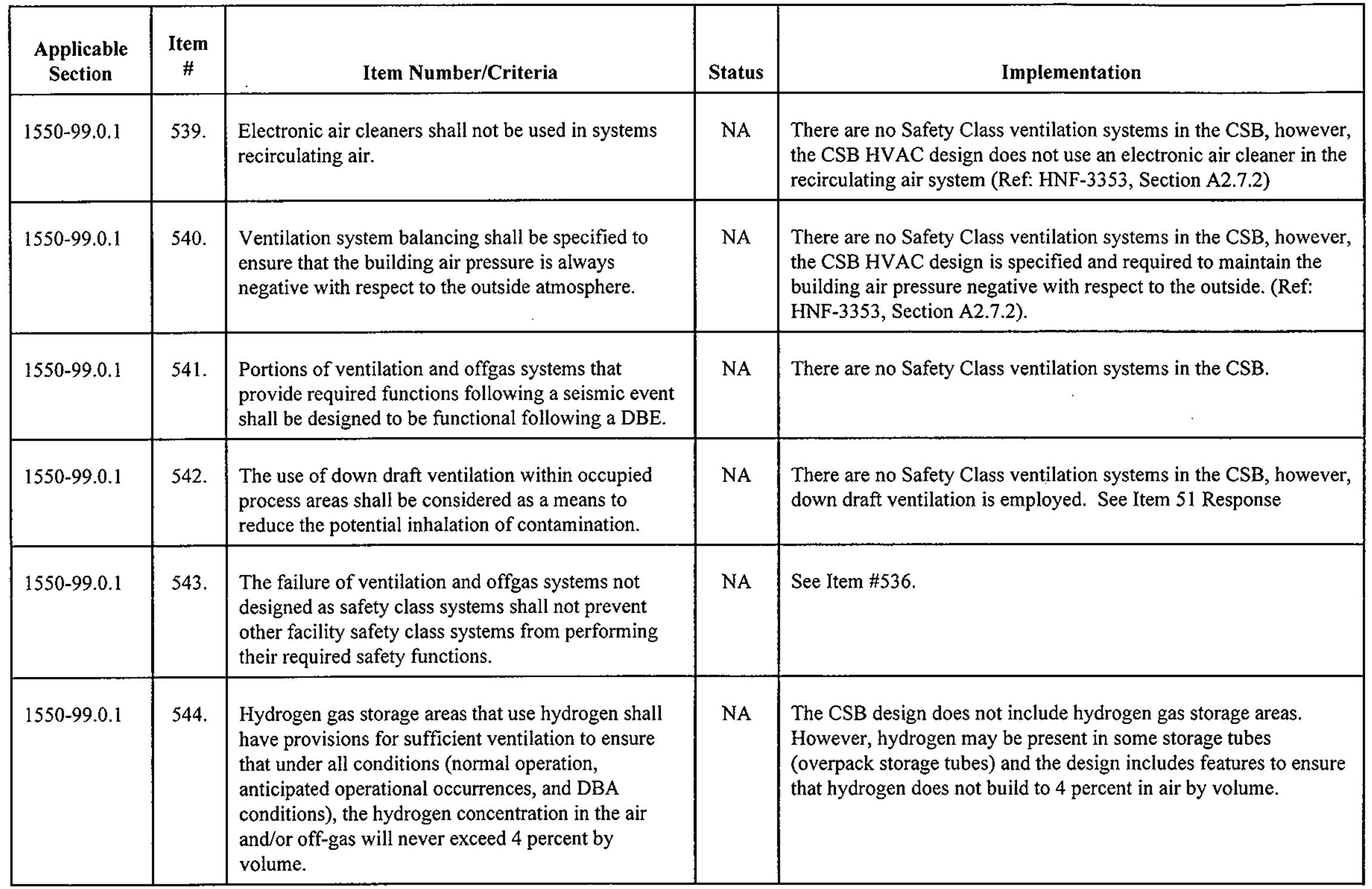




\section{Canister Storage Building Compliance Assessment DOE Order 6430.1A, General Design Criteria}

HNF-4742, Rev. 0

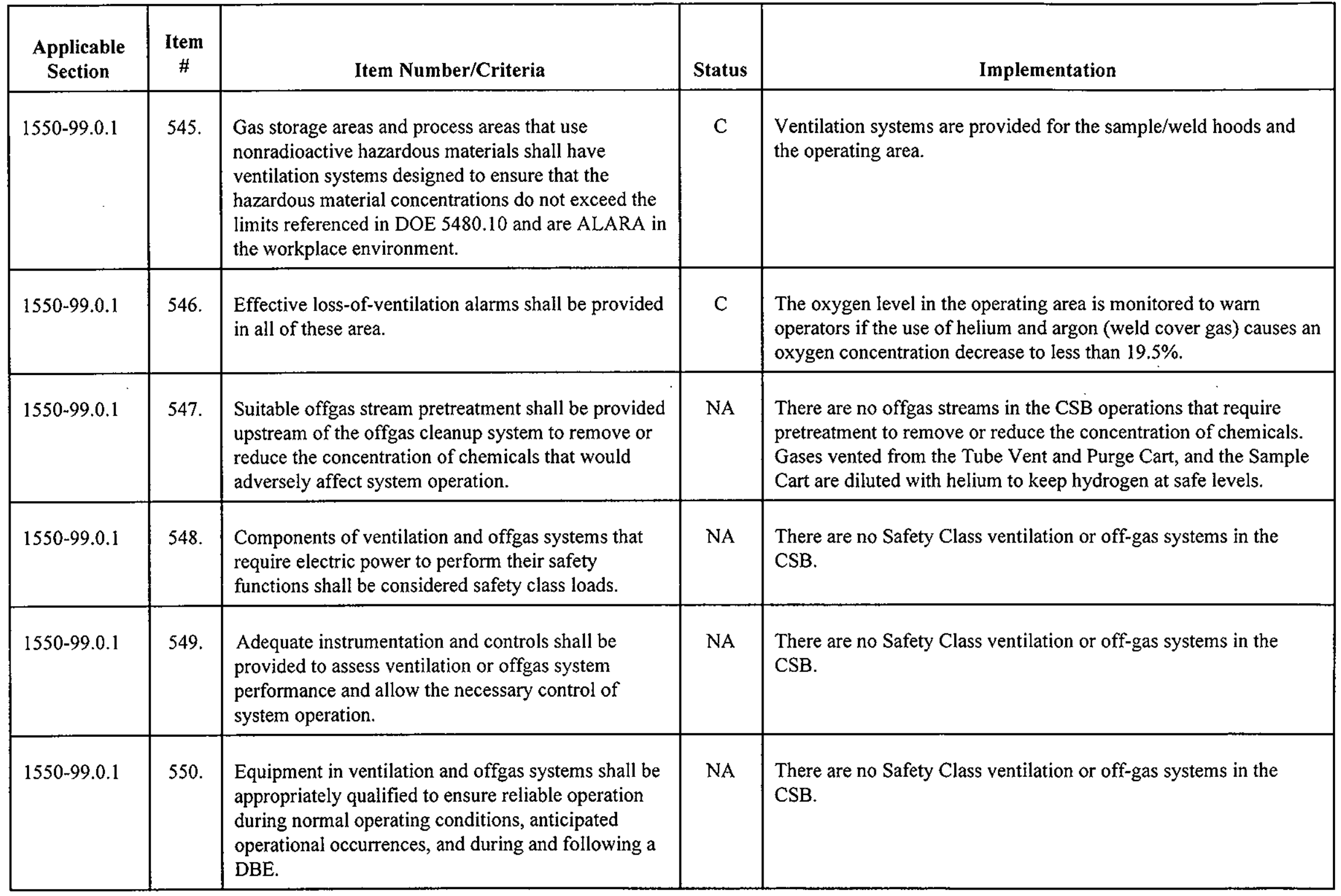




\section{Canister Storage Building Compliance Assessment DOE Order 6430.1A, General Design Criteria}

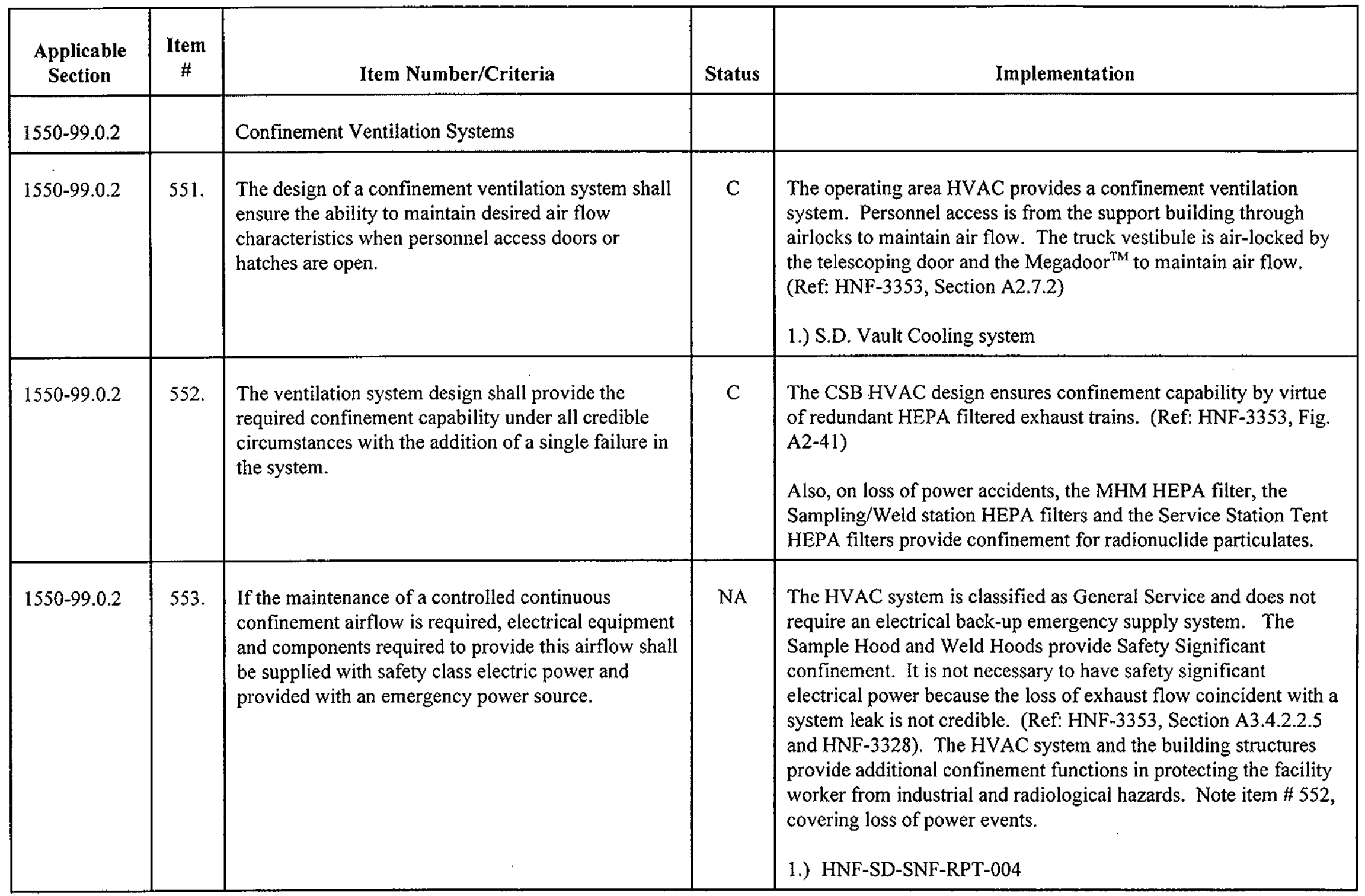




\section{Canister Storage Building Compliance Assessment DOE Order 6430.1A, General Design Criteria}

\begin{tabular}{|c|c|c|c|c|}
\hline $\begin{array}{c}\text { Applicable } \\
\text { Section }\end{array}$ & $\begin{array}{c}\text { Item } \\
\#\end{array}$ & Item Number/Criteria & Status & Implementation \\
\hline $1550-99.0 .2$ & 555. & $\begin{array}{l}\text { The level of radioactive material in confinement } \\
\text { exhaust systems shall be continuously monitored. } \\
\text { Alarms shall be provided that will annunciate in the } \\
\text { event that activity levels above specified limits are } \\
\text { detected in the exhaust stream. }\end{array}$ & C & $\begin{array}{l}\text { The CSB HVAC system design has alarms that will annunciate in } \\
\text { the event that activity levels above specified limits are detected in } \\
\text { the exhaust flow. The Gaseous Effluent Monitoring System } \\
\text { (GEMS) (ref: HNF-3553, Section A2.7.4) would alarm/annunciate } \\
\text { on high rad signal. } \\
\text { In addition, the GEMS provides data for stack releases. There are } \\
\text { no automatic shut down features for the HVAC, ventilation is } \\
\text { designed to be constant providing a defense-in-depth confinement } \\
\text { function for airborne radioactivity. }\end{array}$ \\
\hline
\end{tabular}




\section{Canister Storage Building Compliance Assessment DOE Order 6430.1A, General Design Criteria}

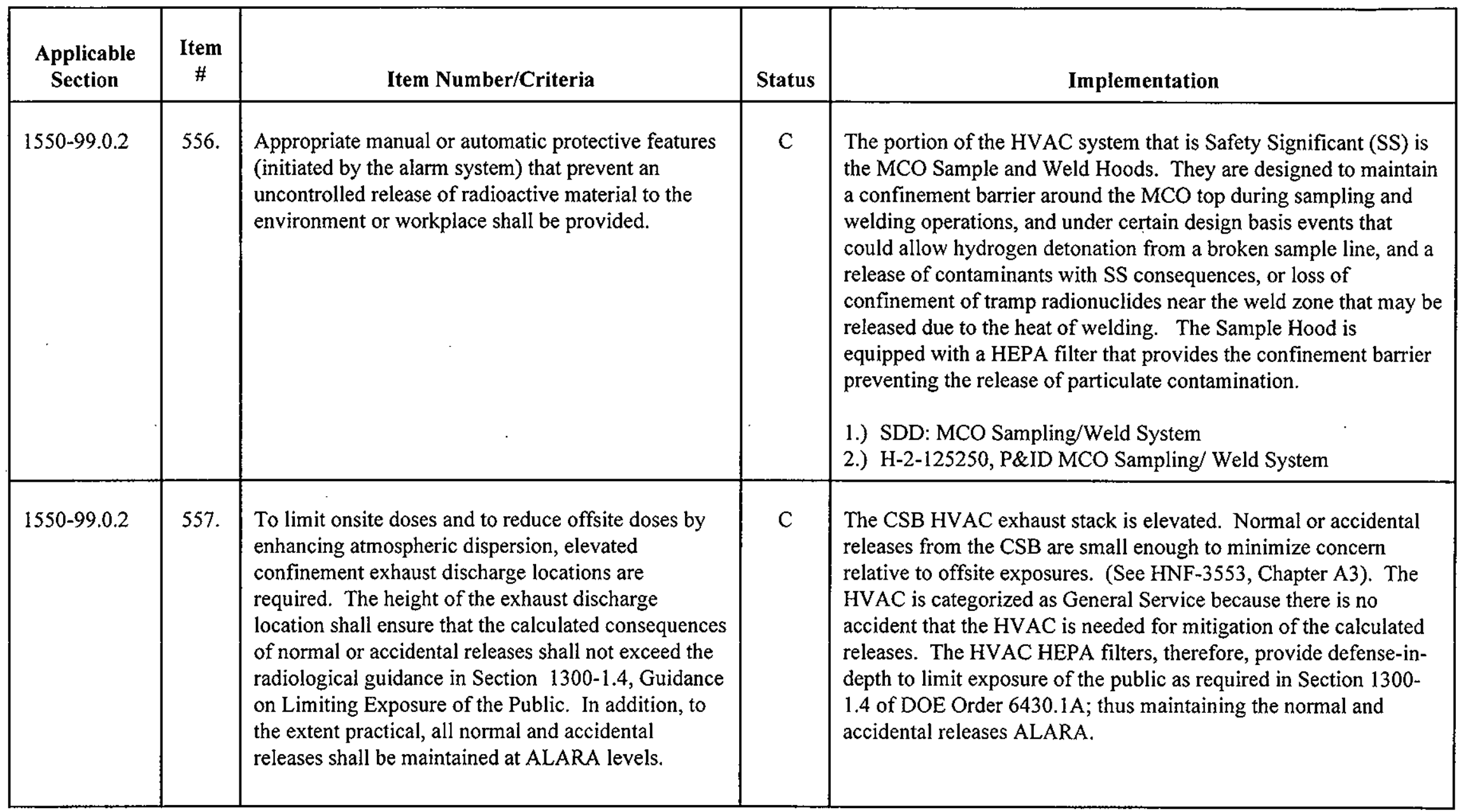




\section{Canister Storage Building Compliance Assessment DOE Order 6430.1A, General Design Criteria}

HNF-4742, Rev. 0

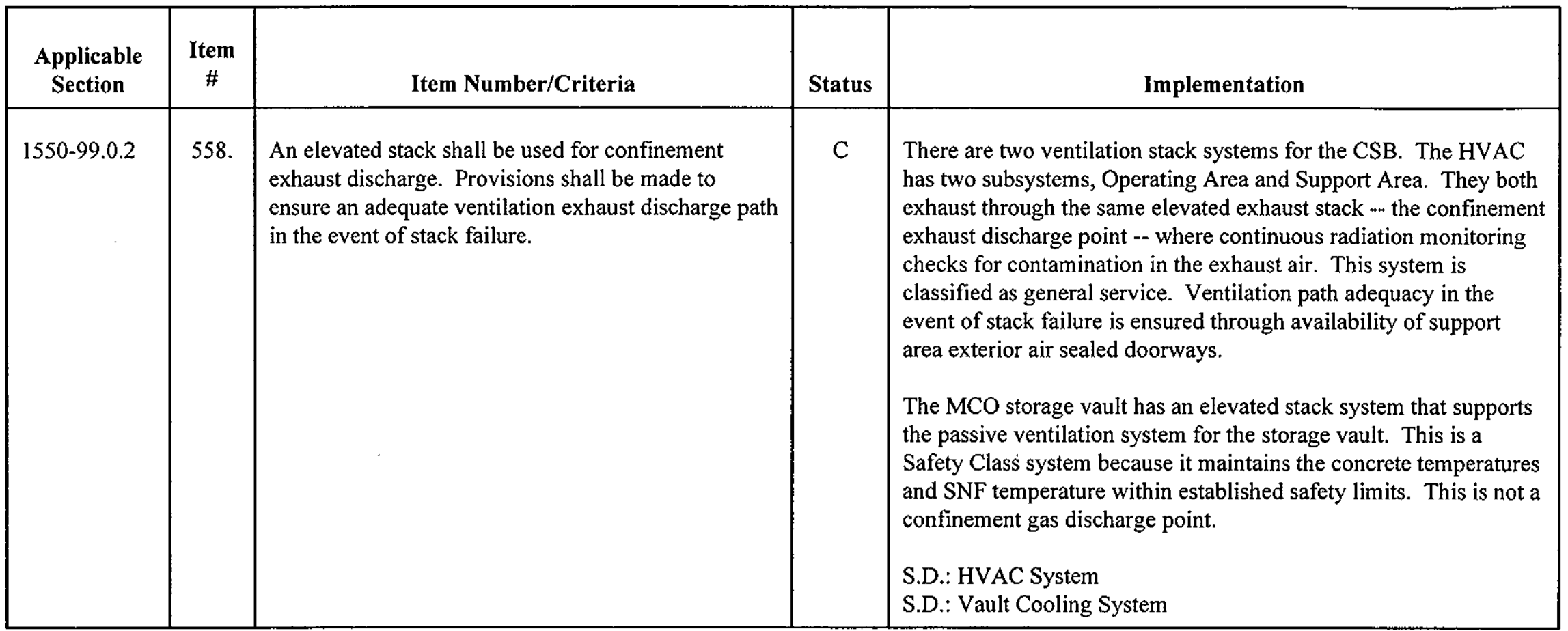




\section{Canister Storage Building Compliance Assessment DOE Order 6430.1A, General Design Criteria}

HNF-4742, Rev. 0

\begin{tabular}{|c|c|c|c|c|}
\hline $1550-99.0 .2$ & 560. & $\begin{array}{l}\text { Safety class air filtration units shall be designed to } \\
\text { remain functional throughout DBAs and to retain } \\
\text { radioactive collected materials after the accident. }\end{array}$ & NA & $\begin{array}{l}\text { There is no Safety Class air filtration associated with the CSB } \\
\text { operations. } \\
\text { S.D.: MCO Sampling/Weld System }\end{array}$ \\
\hline
\end{tabular}




\section{Canister Storage Building Compliance Assessment DOE Order 6430.1A, General Design Criteria}

\begin{tabular}{|c|c|c|c|c|}
\hline $1550-99.0 .2$ & 562. & $\begin{array}{l}\text { The number of air filtration stages required for any } \\
\text { area of a facility shall be determined by safety } \\
\text { analysis based on the quantity and type of radioactive } \\
\text { materials to be confined. }\end{array}$ & $\mathrm{C}$ & $\begin{array}{l}\text { The number of exhaust filtration stages are sufficient to limit } \\
\text { concentrations of airborne radioactive particulates released to the } \\
\text { environment to less than the applicable limits at the point of } \\
\text { discharge during all anticipated operating conditions. The } \\
\text { filtration systems conform to ALARA principles and comply with } \\
\text { DOE Order 5480.1A requirements during abnormal, accident, and } \\
\text { DBA conditions. } \\
\text { DBD, section 6, paragraph 6.3.4(2) }\end{array}$ \\
\hline $1550-99.0 .2$ & 563. & $\begin{array}{l}\text { Air filtration units shall be installed as close as } \\
\text { practical to the source of contaminants to minimize } \\
\text { the contamination of ventilation system ductwork. }\end{array}$ & $\mathrm{C}$ & $\begin{array}{l}\text { Air filtration units are designed and located within } 30 \text { feet of the } \\
\text { source of contaminants and minimize contamination of ventilation } \\
\text { system ductwork. } \\
\text { DBD, section 6, paragraph } 6.3 .4(4)\end{array}$ \\
\hline $1550-99.0 .2$ & 564. & $\begin{array}{l}\text { Ducts shall be sized for the transport velocities } \\
\text { needed to convey without settling all particulate } \\
\text { contaminants. }\end{array}$ & $\mathrm{C}$ & $\begin{array}{l}\text { The HVAC ducts are designed to meet the requirements of the } \\
\text { Operations and Support Area ventilation requirements. See S.DD: } \\
\text { HVAC System description, section 1.4. Transport velocities are } \\
\text { sufficient to prevent settling of particulate contaminants. }\end{array}$ \\
\hline
\end{tabular}




\section{Canister Storage Building Compliance Assessment \\ DOE Order 6430.1A, General Design Criteria}

HNF-4742, Rev. 0

\begin{tabular}{|l|c|l|c|c|}
\hline $\begin{array}{c}\text { Applicable } \\
\text { Section }\end{array}$ & $\begin{array}{c}\text { Item } \\
\text { \# }\end{array}$ & \multicolumn{1}{|c|}{ Item Number/Criteria } & Status & Implementation \\
\hline $1550-99.0 .2$ & 565. & $\begin{array}{l}\text { Air filtration units shall be located and provided with } \\
\text { appropriate radiation shielding to maintain } \\
\text { occupational doses ALARA during operations and } \\
\text { maintenance. }\end{array}$ & C & $\begin{array}{l}\text { Expected levels of contamination do not require that additional } \\
\text { shielding of HEPA filters, or other filtration units, be provided. } \\
\text { Filter change-out will be based on an experience based } \\
\text { combination of radiation monitoring and pressure drop monitoring. } \\
\text { See item \#563 above. }\end{array}$ \\
\hline $1550-99.0 .2$ & 566. & $\begin{array}{l}\text { Air filtration units shall be designed for ease of } \\
\text { recovery of fissile material and other materials } \\
\text { capable of sustaining a chain reaction in case of an } \\
\text { accident as well as during normal operations. }\end{array}$ & NA & $\begin{array}{l}\text { No appreciable amounts of fissile materials will be collected on } \\
\text { HEPA, or other, filters. (Ref: HNF-3553, Section A2.7.2). }\end{array}$ \\
\hline $1550-99.0 .2$ & 567. & $\begin{array}{l}\text { The cleanup system shall have installed test and } \\
\text { measuring devices and shall facilitate monitoring } \\
\text { operations, maintenance, and periodic inspection and } \\
\text { testing during equipment operation or shutdown, as } \\
\text { appropriate. }\end{array}$ & NA & $\begin{array}{l}\text { Special cleanup systems are not required in CSB air filtration } \\
\text { systems. See response to item \#563. } \\
\text { Appropriate radiation protection is provided to maintain } \\
\text { occupational doses ALARA during operations and maintenance } \\
\text { and the main building systems are designed so that a bank of filters } \\
\text { can be completely isolated from the ventilation system during filter } \\
\text { element replacement. } \\
\text { DBD, section 6, paragraph 6.3.2(6) }\end{array}$ \\
\hline
\end{tabular}




\section{Canister Storage Building Compliance Assessment \\ DOE Order 6430.1A, General Design Criteria}

HNF-4742, Rev. 0

\begin{tabular}{|c|c|c|c|c|}
\hline $1550-99.0 .2$ & 570. & $\begin{array}{l}\text { Consideration shall be given to providing roughing } \\
\text { filters or prefilters upstream of a HEPA filter to } \\
\text { maximize the useful life of the HEPA filter and } \\
\text { reduce radioactive waste volume. }\end{array}$ & $\mathrm{C}$ & $\begin{array}{l}\text { The HEPA filtration systems are designed with prefilters installed } \\
\text { upstream of HEPA filters to extend HEPA filter life. } \\
\text { DBD, section } 6 \text {, HVAC, paragraph } 6.3 .4(6)\end{array}$ \\
\hline $1550-99.0 .3$ & & Off-Gas systems & & \\
\hline
\end{tabular}




\section{Canister Storage Building Compliance Assessment \\ DOE Order 6430.1A, General Design Criteria}

\begin{tabular}{|c|c|c|c|c|}
\hline $\begin{array}{l}\text { Applicable } \\
\text { Section }\end{array}$ & $\begin{array}{c}\text { Item } \\
\#\end{array}$ & Item Number/Criteria & Status & Implementation \\
\hline $1550-99.0 .3$ & 573. & $\begin{array}{l}\text { Electrical equipment and components of off-gas } \\
\text { systems that require electric power to perform their } \\
\text { safety functions shall be considered safety class } \\
\text { loads. }\end{array}$ & NA & $\begin{array}{l}\text { The gaseous emissions monitoring system is classified general } \\
\text { service and an emergency power supply system is not required. } \\
\text { The uninterruptible power supply system provides temporary } \\
\text { power for the emissions monitoring system during loss of normal } \\
\text { power. }\end{array}$ \\
\hline
\end{tabular}




\section{Canister Storage Building Compliance Assessment DOE Order 6430.1A, General Design Criteria}

HNF-4742, Rev. 0

\begin{tabular}{|c|c|c|c|c|}
\hline $1550-99.0 .3$ & 575. & $\begin{array}{l}\text { Appropriate manual or automatic protective features } \\
\text { shall be provided to prevent an uncontrolled release } \\
\text { of radioactive material to the environment and to } \\
\text { minimize the spread of contamination within the } \\
\text { facility. }\end{array}$ & $\mathrm{C}$ & $\begin{array}{l}\text { Uncontrolled release of radionuclides to the environment is } \\
\text { prevented by the nature of the MCO storage system. No additional } \\
\text { protective features are provided for normal MCOs. Overpack- } \\
\text { stored MCOs may be leaking. The escape of radionuclides from } \\
\text { Overpack-stored MCOs is prevented by manually secured, } \\
\text { pressure retaining overpack tube plugs. Periodic surveillance of } \\
\text { the overpack storage tubes is provided by the Tube Vent and Purge } \\
\text { Cart. Note response to \# } 572 \text {. }\end{array}$ \\
\hline $1550-99.0 .3$ & 577. & $\begin{array}{l}\text { The system's capacity shall be consistent with the } \\
\text { needs for handling off-gas from components and } \\
\text { systems during normal operations, anticipated } \\
\text { operational occurrences, and DBA conditions. }\end{array}$ & $\mathrm{C}$ & Note response to \# 572 . \\
\hline $1550-99.0 .3$ & 578. & $\begin{array}{l}\text { Process system tanks and other sealed components } \\
\text { shall be vented to an off-gas system. }\end{array}$ & C & $\begin{array}{l}\text { The vent flow from the sampling hood exhaust systems is designed } \\
\text { to flow through a duct that connects to the exhaust ducting from } \\
\text { the operating area. The exhaust from the tube vent and purge cart, } \\
\text { the MHM cask, and the transportation cask service system is } \\
\text { vented into the operating area exhaust stream. through HEPA } \\
\text { filters. }\end{array}$ \\
\hline
\end{tabular}




\section{Canister Storage Building Compliance Assessment DOE Order 6430.1A, General Design Criteria}

\begin{tabular}{|c|c|c|c|c|}
\hline $\begin{array}{l}\text { Applicable } \\
\text { Section }\end{array}$ & $\begin{array}{l}\text { Item } \\
\#\end{array}$ & Item Number/Criteria & Status & Implementation \\
\hline $1550-99.0 .3$ & 580. & $\begin{array}{l}\text { Vents from liquid components shall be provided with } \\
\text { traps and drains to prevent inadvertent flooding of } \\
\text { off-gas systems. }\end{array}$ & NA & $\begin{array}{l}\text { The CSB has no systems with liquid components that need a trap } \\
\text { or drain. HVAC condensate and condensate from the air } \\
\text { compressors drain into the support building sumps. }\end{array}$ \\
\hline $1550-99.0 .3$ & 581. & $\begin{array}{l}\text { Adequate shielding shall be provided for filters, } \\
\text { absorbers, scrubbers, and other off-gas treatment } \\
\text { system components to maintain occupational } \\
\text { exposures within the limits specified in DOE } \\
5480.11 \text {. In addition to the extent practical, the } \\
\text { shielding design shall use ALARA principles to } \\
\text { minimize overall exposures. }\end{array}$ & NA & $\begin{array}{l}\text { There are no absorbers or scrubbers. Filters in the ventilation } \\
\text { systems are to be monitored for radioactivity and pressure build } \\
\text { up. Periodic surveillance of filters by the RCTs will provide for } \\
\text { detection and exchange of filters before the dose rate can have an } \\
\text { adverse effect on personnel exposure. The dose limits for the } \\
\text { filters provides for ALARA control of personnel exposure. }\end{array}$ \\
\hline $1550-99.0 .3$ & 582. & $\begin{array}{l}\text { Corrosive gases and particles from vats, scrubbers, } \\
\text { and similar equipment in gloveboxes shall be } \\
\text { neutralized prior to reaching the HEPA off-gas } \\
\text { filters. }\end{array}$ & NA & $\begin{array}{l}\text { There are no corrosive gases associated with planned CSB } \\
\text { operations or design basis accidents. }\end{array}$ \\
\hline $1550-99.0 .3$ & 583. & $\begin{array}{l}\text { Air ventilated gloveboxes shall have the ability to } \\
\text { safely contain in-box contaminants when an access } \\
\text { port is opened or a glove ruptures. }\end{array}$ & NA & $\begin{array}{l}\text { There are no gloveboxes in the CSB. However, the sample hood } \\
\text { and the weld hoods are open bottomed hoods that are designed to } \\
\text { safely confine contaminants through face velocity of the airstream } \\
\text { that could entrain contaminants. }\end{array}$ \\
\hline
\end{tabular}




\section{Canister Storage Building Compliance Assessment \\ DOE Order 6430.1A, General Design Criteria}

HNF-4742, Rev. 0

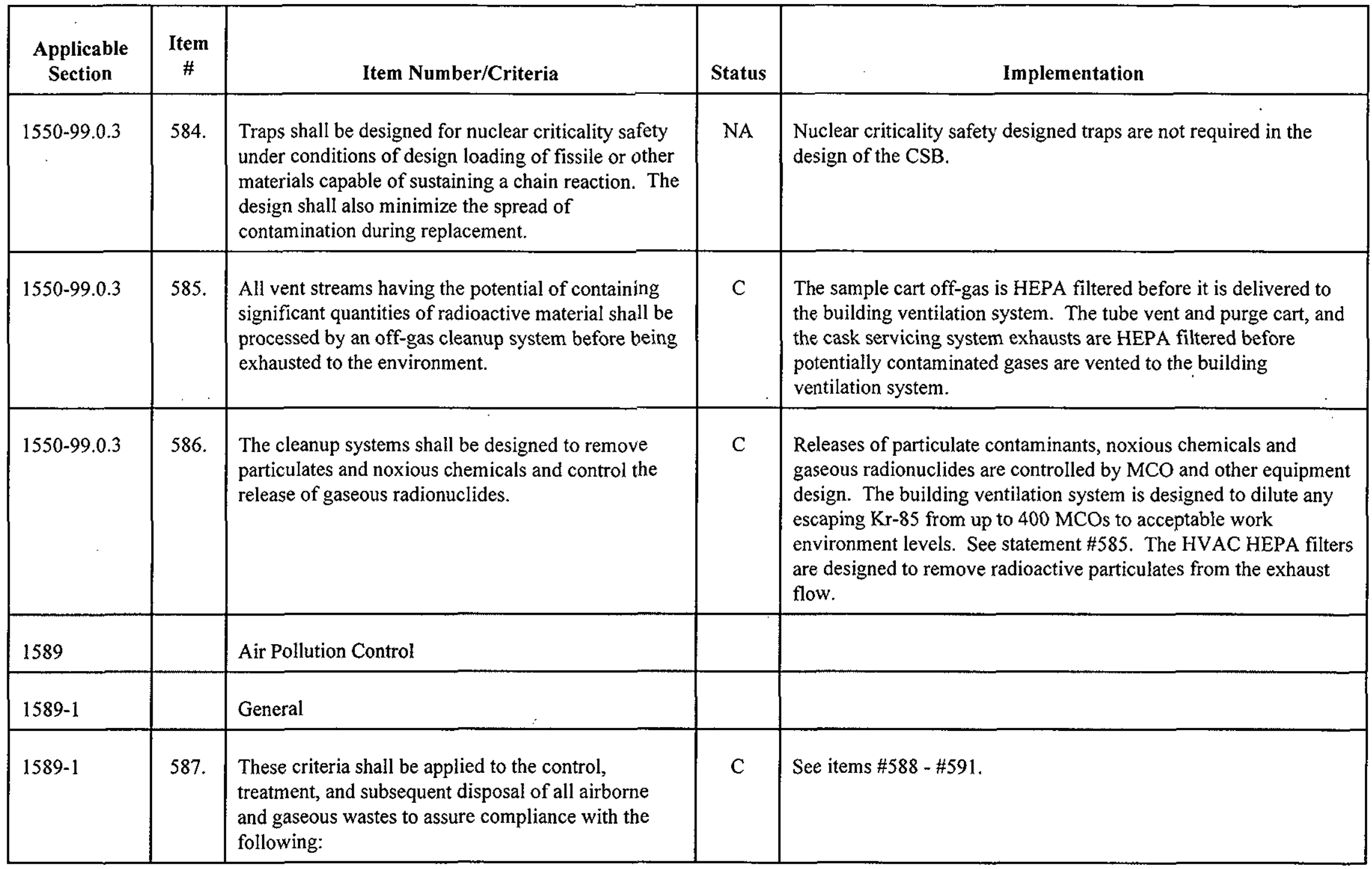




\section{Canister Storage Building Compliance Assessment \\ DOE Order 6430.1A, General Design Criteria}

HNF-4742, Rev. 0

\begin{tabular}{|c|c|c|c|c|}
\hline $\begin{array}{l}\text { Applicable } \\
\text { Section }\end{array}$ & $\begin{array}{l}\text { Item } \\
\#\end{array}$ & Item Number/Criteria & Status & Implementation \\
\hline $1589-1$ & 590. & DOE 5480.4 & $\mathrm{C}$ & $\begin{array}{l}\text { General Health Protection Standards were applied to CSB design. } \\
\text { Note Section A2.7.3 of the CSB FSAR. }\end{array}$ \\
\hline $1589-2$ & & Improved Risk Concept & & \\
\hline
\end{tabular}




\section{Canister Storage Building Compliance Assessment \\ DOE Order 6430.1A, General Design Criteria}

HNF-4742, Rev. 0

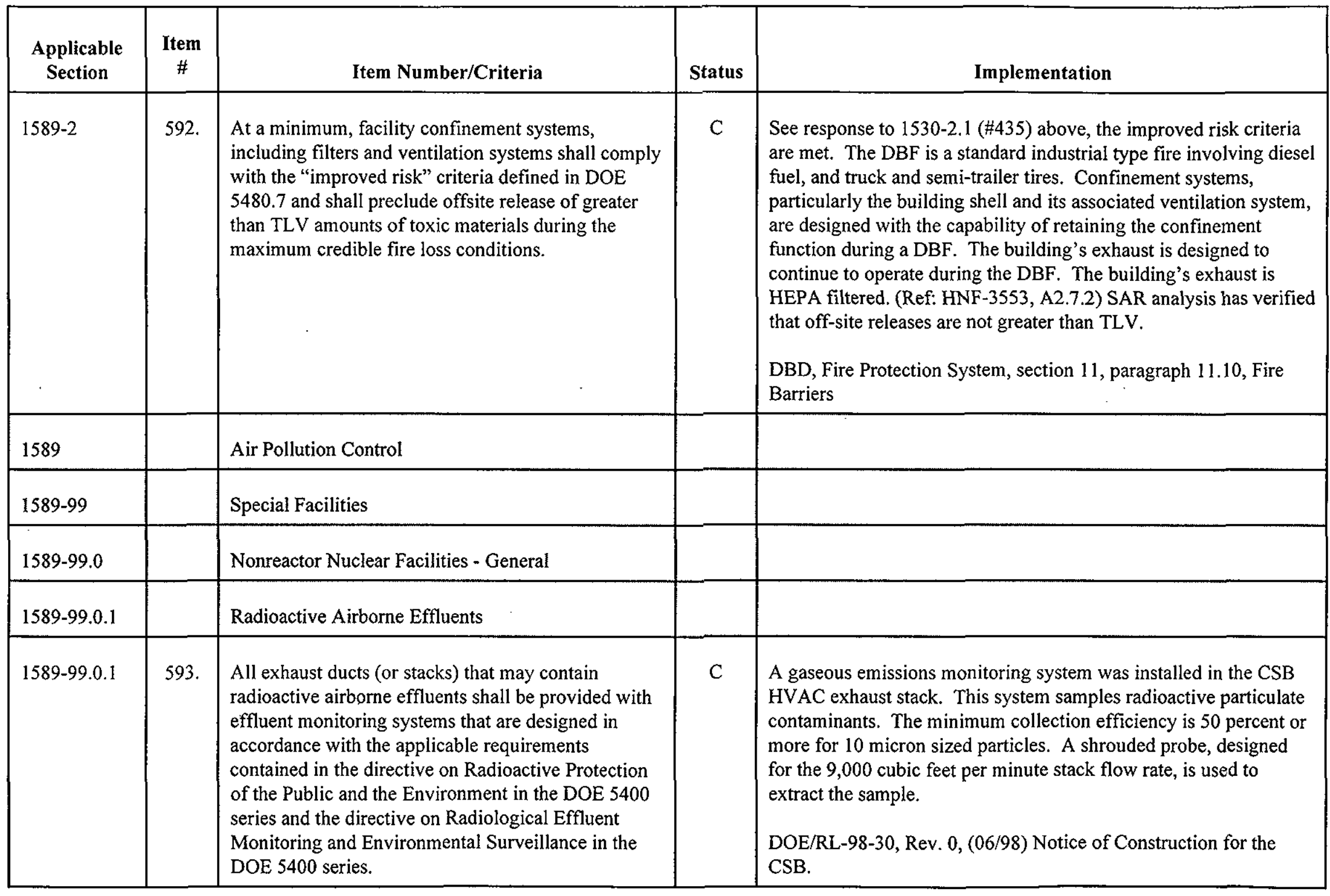




\section{Canister Storage Building Compliance Assessment DOE Order 6430.1A, General Design Criteria}

HNF-4742, Rev. 0

\begin{tabular}{|c|c|c|c|c|}
\hline $1589-99.0 .1$ & 595. & $\begin{array}{l}\text { Continuous stack sampling and continuous radiation } \\
\text { detection shall be considered. Sampling systems } \\
\text { shall be designed in accordance with ANSI N13.1 } \\
\text { and associated appendixes to ensure representative } \\
\text { sampling of the effluent stream. Isokinetic sampling } \\
\text { shall be provided for effluent streams that are } \\
\text { expected to contain particulate radionuclides. The } \\
\text { range capability of continuous monitors shall cover } \\
\text { from routine to potential DBA releases of } \\
\text { radionuclides. }\end{array}$ & $\mathrm{C}$ & $\begin{array}{l}\text { See statement } \# 593 \text { above The sampling system complies with } \\
\text { ANSI N13.1. The effluent monitoring system also monitors the } \\
\text { stack discharge during a DBA. }\end{array}$ \\
\hline $1589-99.0 .1$ & 596. & $\begin{array}{l}\text { Nuclear criticality safety shall be considered in the } \\
\text { design of equipment used to treat and discharge } \\
\text { radioactive airborne effluents. }\end{array}$ & $\mathrm{C}$ & $\begin{array}{l}\text { There is no possibility of criticality in the CSB due to } \\
\text { accumulation of fissile materials in the building ventilation } \\
\text { equipment. } \\
\text { The safety analysis report considered nuclear criticality as a set of } \\
\text { the bounding and credible analyses that are applicable to the CSB } \\
\text { facility (see SAR section } 6.3 \text { ) } \\
\text { HNF-SD-SNF-RPT-004 } \\
\text { section } 6.0 \text {, prevention of inadvertent criticality. }\end{array}$ \\
\hline $1589-99.0 .2$ & & Nonradioactive Airborne Effluents & & \\
\hline
\end{tabular}




\section{Canister Storage Building Compliance Assessment \\ DOE Order 6430.1A, General Design Criteria}

HNF-4742, Rev. 0

\begin{tabular}{|c|c|c|c|c|}
\hline $\begin{array}{l}\text { Applicable } \\
\text { Section }\end{array}$ & $\begin{array}{l}\text { Item } \\
\#\end{array}$ & Item Number/Criteria & Status & Implementation \\
\hline 1595 & & Controls & & \\
\hline $1595-1$ & & General & & \\
\hline $1595-1$ & 599. & $\begin{array}{l}\text { All control equipment shall be easily accessible. One } \\
\text { temperature control panel shall be provided for each } \\
\text { system, complete with panel-face-mounted } \\
\text { indicators, switches, pilot lights, and tags. All } \\
\text { control interlocks shall be through HOA switches. }\end{array}$ & $\mathrm{C}$ & $\begin{array}{l}\text { Control equipment is easily accessible. Temperature control } \\
\text { panels are provided as appropriate. HOA switches are provided. }\end{array}$ \\
\hline
\end{tabular}




\section{Canister Storage Building Compliance Assessment \\ DOE Order 6430.1A, General Design Criteria}

HNF-4742, Rev. 0

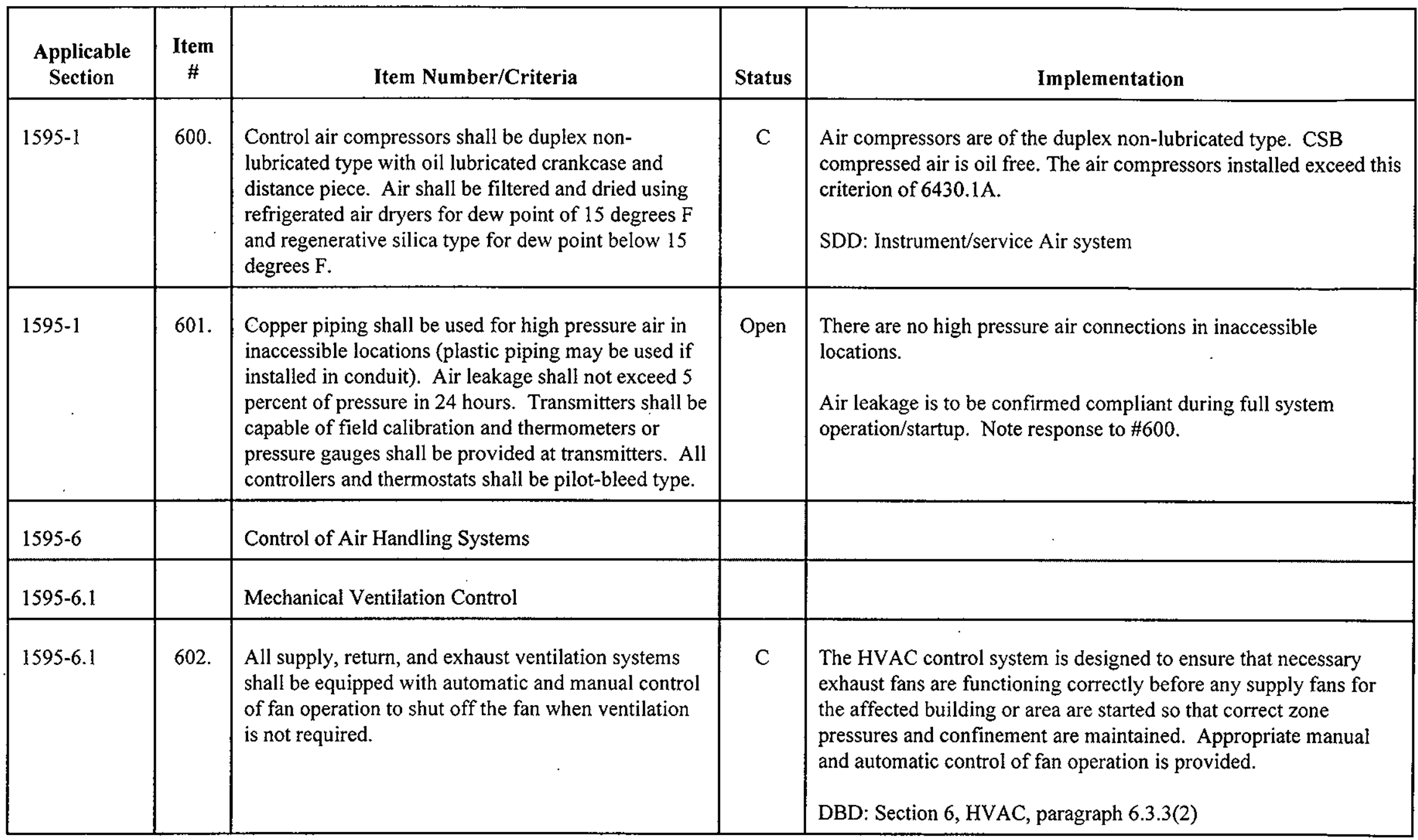




\section{Canister Storage Building Compliance Assessment \\ DOE Order 6430.1A, General Design Criteria}

HNF-4742, Rev. 0

\begin{tabular}{|c|c|c|c|c|}
\hline $\begin{array}{l}\text { Applicable } \\
\text { Section }\end{array}$ & $\begin{array}{l}\text { Item } \\
\#\end{array}$ & Item Number/Criteria & Status & Implementation \\
\hline $1595-6.1$ & 604. & $\begin{array}{l}\text { Systems that circulate air shall be provided with } \\
\text { minimum outdoor air damper position control to } \\
\text { assure that the minimum outdoor air quantity is being } \\
\text { introduced to the system. }\end{array}$ & $\mathrm{C}$ & Appropriate damper control of outside air is provided. \\
\hline $1595-6.1$ & 605. & $\begin{array}{l}\text { Automatic dampers should fail open for return air } \\
\text { and fail closed for outside air. }\end{array}$ & $\mathrm{C}$ & $\begin{array}{l}\text { The automatic return and outside air damper control for } \\
\text { AH- } 003(\mathrm{CD}-3 \text { ) regulates outside air from } 42 \text { to } 100 \% \\
\text { of total flow and regulates return air from } 0 \text { to } 58 \% \text { of } \\
\text { total flow. The automatic damper fails in the } 42 \% \\
\text { position (outside air) and } 58 \% \text { position (return air) to } \\
\text { provide minimum air flow for the support area rooms. } \\
\text { FSAR: Figure A2-47 }\end{array}$ \\
\hline $1595-6.3$ & & Automatic Control Dampers & & \\
\hline
\end{tabular}




\section{Canister Storage Building Compliance Assessment \\ DOE Order 6430.1A, General Design Criteria}

HNF-4742, Rev. 0

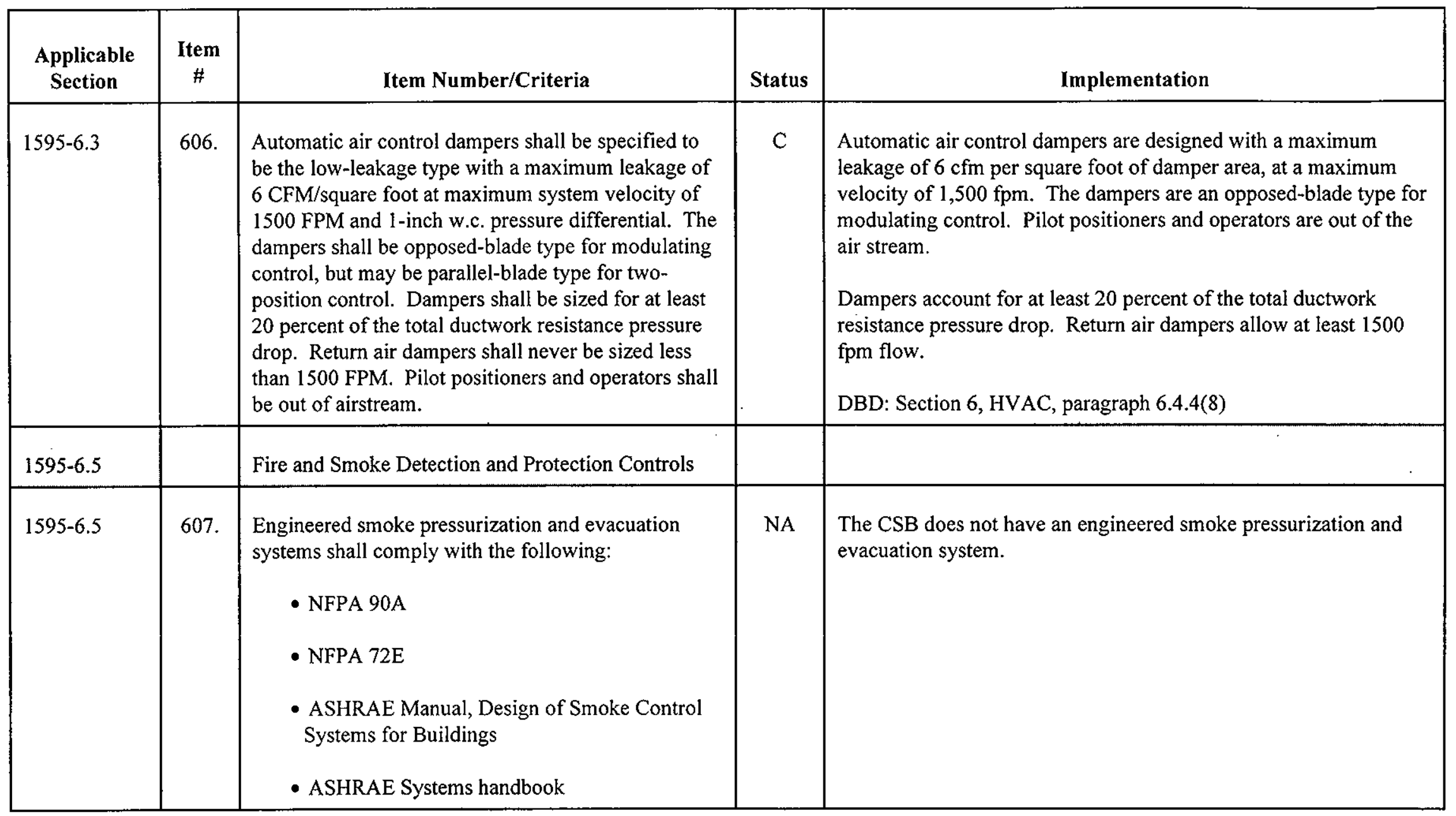




\section{Canister Storage Building Compliance Assessment \\ DOE Order 6430.1A, General Design Criteria}

HNF-4742, Rev. 0

\begin{tabular}{|c|c|c|c|c|}
\hline $\begin{array}{l}\text { Applicable } \\
\text { Section }\end{array}$ & $\begin{array}{l}\text { Item } \\
\#\end{array}$ & Item Number/Criteria & Status & Implementation \\
\hline $1595-6.5$ & 609. & $\begin{array}{l}\text { All supply, return, relief, and exhaust air ventilation } \\
\text { systems shall have interlock controls that interface } \\
\text { with fire and smoke detection system controls and } \\
\text { either turn off or selectively operate fans and } \\
\text { dampers to prevent the spread of smoke and fire } \\
\text { throughout the building. These controls shall comply } \\
\text { with NFPA 90A. }\end{array}$ & $\mathrm{C}$ & Controls are compliant with NFPA 90A. Note response to \# 608 . \\
\hline 1605 & & Electrical Materials and Methods & & \\
\hline $1605-1$ & & General & & \\
\hline
\end{tabular}




\section{Canister Storage Building Compliance Assessment \\ DOE Order 6430.1A, General Design Criteria}

HNF-4742, Rev. 0

\begin{tabular}{|c|c|c|c|c|}
\hline $1605-1$ & 612. & $\begin{array}{l}\text { Electrical systems shall be designed so that all } \\
\text { components operate within their capacities for initial } \\
\text { and projected loads. }\end{array}$ & C & $\begin{array}{l}\text { The electrical system is designed for continuous reliable service } \\
\text { and allows CSB components to operate within their rated } \\
\text { capacities for initial and projected loads. } \\
\text { DBD: Section 5, Electrical, paragraph } 5.4 .1\end{array}$ \\
\hline $1605-1$ & 614. & $\begin{array}{l}\text { Electrical materials and equipment shall be UL- or } \\
\text { FM-tested, with label attached, for the purpose } \\
\text { intended, whenever such products are available. } \\
\text { Where there are no UL- or FM- listed products of the } \\
\text { type, testing and certification by another nationally } \\
\text { recognized testing agency may be acceptable. }\end{array}$ & Open & $\begin{array}{l}\text { Designed and installed electrical materials and equipment are UL- } \\
\text { or FM-tested, with label attached, for the purpose intended. } \\
\text { Regarding the MHM, UL inspector found items to be corrected } \\
\text { and will issue a certification of compliance for the MHM following } \\
\text { system energization. } \\
\text { DBD: Section 5, Electrical, paragraph } 5.4 .7(1)\end{array}$ \\
\hline
\end{tabular}




\section{Canister Storage Building Compliance Assessment \\ DOE Order 6430.1A, General Design Criteria}

HNF-4742, Rev. 0

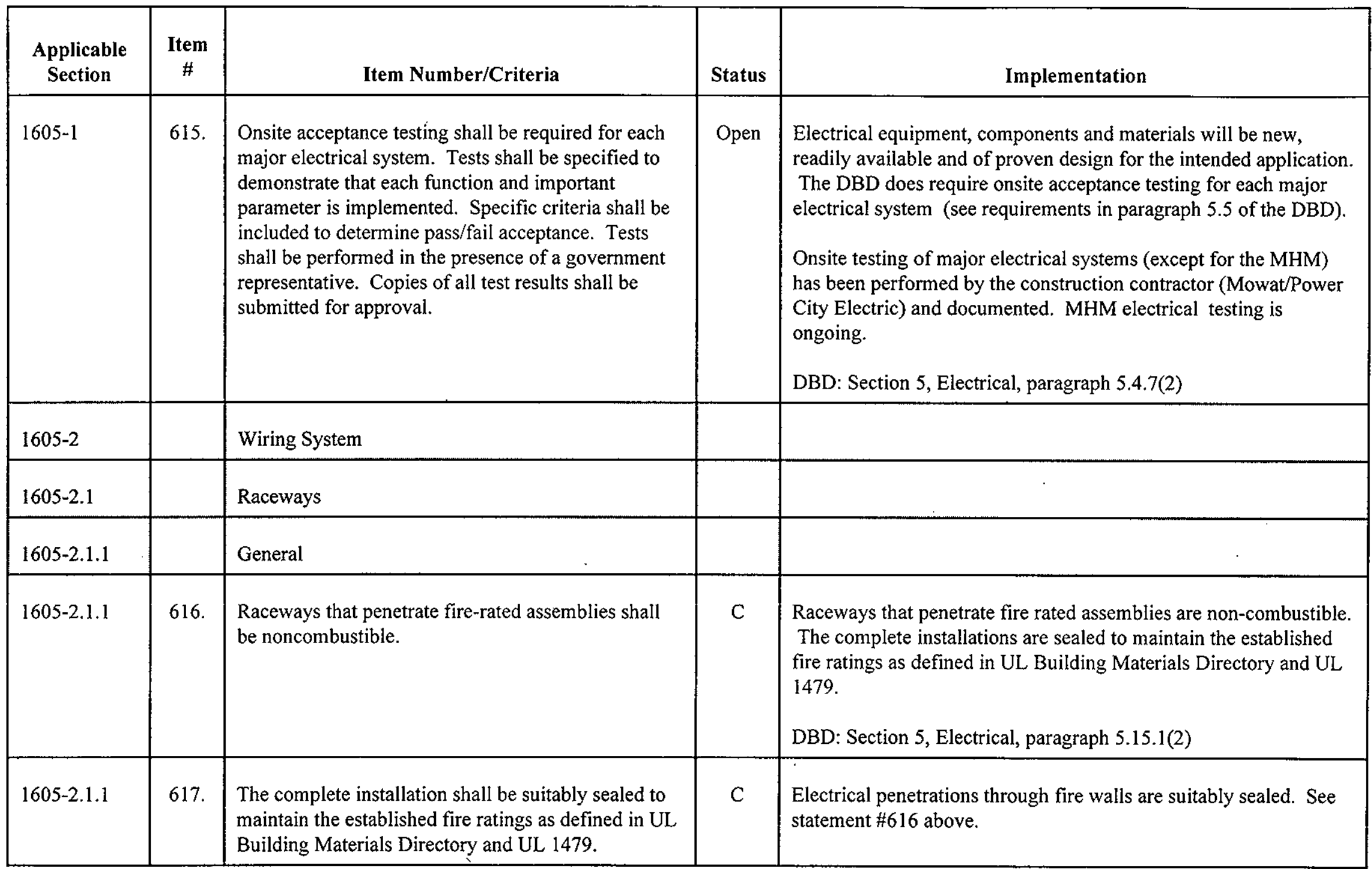




\section{Canister Storage Building Compliance Assessment \\ DOE Order 6430.1A, General Design Criteria}

HNF-4742, Rev. 0

\begin{tabular}{|c|c|c|c|c|}
\hline $\begin{array}{l}\text { Applicable } \\
\text { Section }\end{array}$ & $\stackrel{\text { Item }}{\#}$ & Item Number/Criteria & Status & Implementation \\
\hline $1605-2.1 .2$ & & Electrical Metallic Tubing & & \\
\hline $1605-2.1 .2$ & 619. & $\begin{array}{l}\text { Electrical Metallic Tubing (EMT) shall be used to } \\
\text { enclose circuit power conductors, alarm and signal } \\
\text { circuits in nonhazardous and noncorrosive locations. } \\
\text { It shall not be installed where subjected to physical } \\
\text { damages during installation or while in service. } \\
\text { EMT shall not be installed underground and shall not } \\
\text { be encased in concrete. When EMT is used outdoors } \\
\text { or in damp locations, compression type (rain tight) } \\
\text { fittings must be used. }\end{array}$ & $\mathrm{C}$ & $\begin{array}{l}\text { EMT is not used in the CSB. Intermediate metal conduit was used } \\
\text { instead. IMC is superior in all performance measures to EMT and } \\
\text { is rain tight. } \\
\text { DBD: Section 5, Electrical, paragraph 5.15.3.(3), (4), (8),(9), and } \\
\text { (10). Approved deviation letter 92-PMD-253 dated } 7 / 13 / 92 \text {. }\end{array}$ \\
\hline $1605-2.1 .3$ & & Flexible Steel Conduit & & \\
\hline $1605-2.1 .3$ & 620 & $\begin{array}{l}\text { Flexible steel conduit shall be used for connection to } \\
\text { equipment subject to vibration and connection from } \\
\text { junction boxes to recessed lighting fixtures. }\end{array}$ & $\mathrm{C}$ & $\begin{array}{l}\text { Flexible steel conduit is used when connecting power to motors, } \\
\text { compressors and other rotating equipment. Recessed lighting } \\
\text { fixtures were not used. }\end{array}$ \\
\hline 1605-2.1.4 & & Rigid Steel Conduit and Intermediate Metal Conduit & & \\
\hline
\end{tabular}




\section{Canister Storage Building Compliance Assessment \\ DOE Order 6430.1A, General Design Criteria}

HNF-4742, Rev. 0

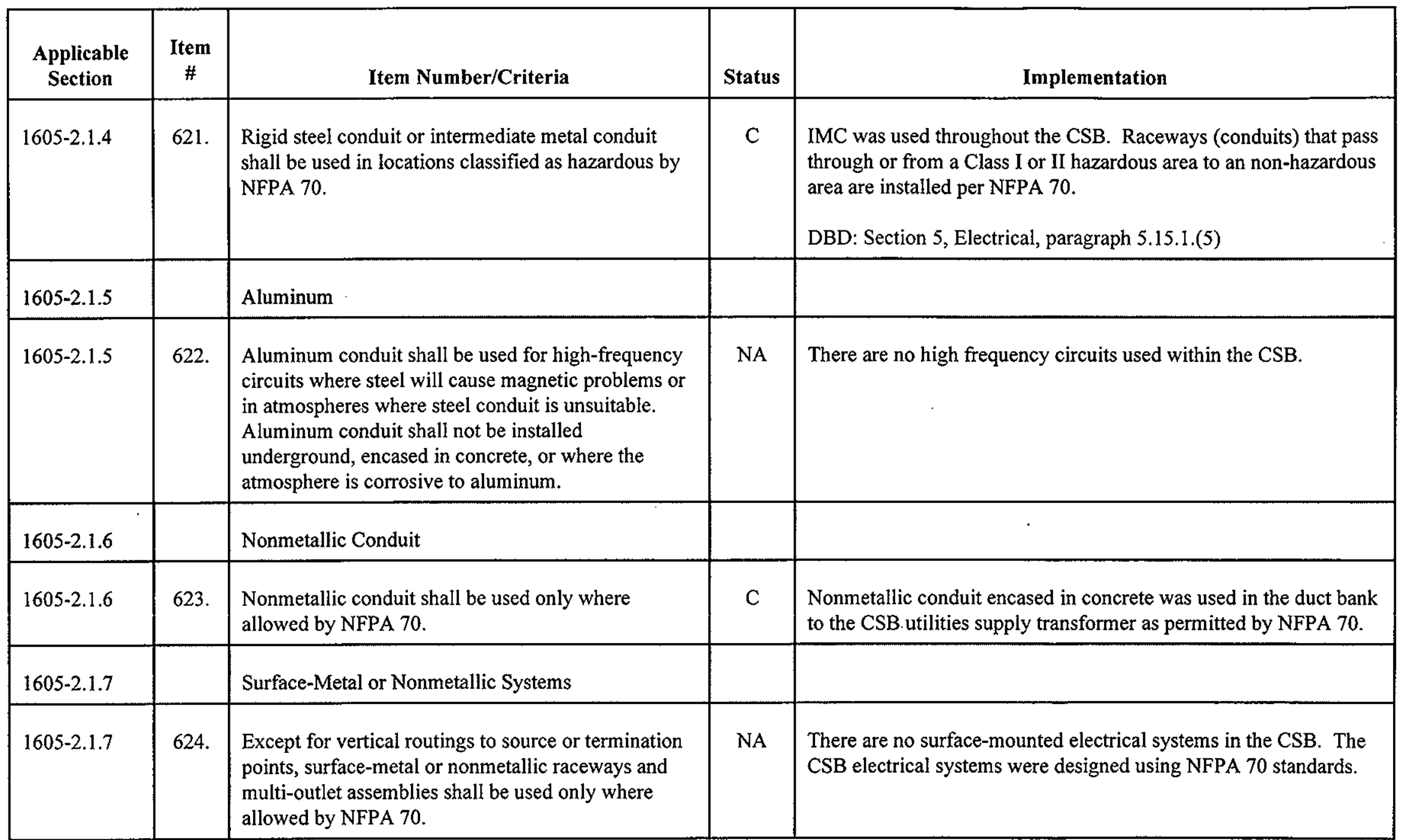




\section{Canister Storage Building Compliance Assessment \\ DOE Order 6430.1A, General Design Criteria}

HNF-4742, Rev. 0

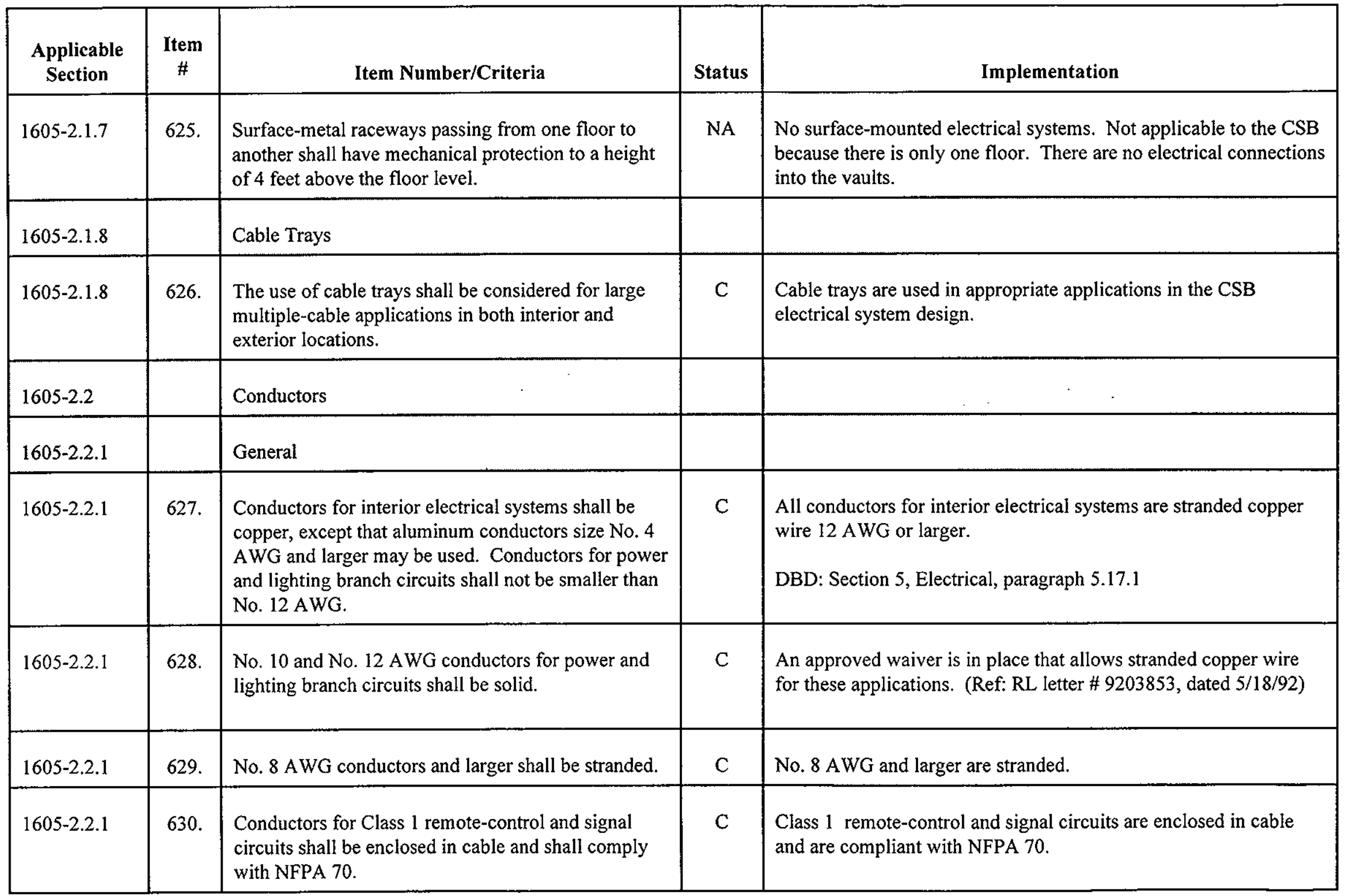




\section{Canister Storage Building Compliance Assessment DOE Order 6430.1A, General Design Criteria}

HNF-4742, Rev. 0

\begin{tabular}{|c|c|c|c|c|}
\hline $1605-2.2 .1$ & 632. & $\begin{array}{l}\text { Power and lighting conductors shall be } 600 \text {-volt, } \\
\text { Type THW, XHHW, or THWN. }\end{array}$ & $\mathrm{C}$ & $\begin{array}{l}\text { Power and lighting conductors are XHHW, or THHN/THWN } \\
\text { rated. }\end{array}$ \\
\hline $1605-2.2 .1$ & 633. & $\begin{array}{l}\text { Conductors required to be rated } 90 \text { degrees } C \text { in } \\
\text { accordance with NFPA } 70 \text { shall be Type RHH, } \\
\text { THW, or THHN. }\end{array}$ & $\mathrm{C}$ & $\begin{array}{l}\text { Conductors required to be } 90 \mathrm{C} \text { rated are RHH, THW, or THHN in } \\
\text { accordance with NFPA } 70 . \\
\text { DBD: Section 5, Electrical, paragraph 5.17.1(2) }\end{array}$ \\
\hline $1605-2.2 .1$ & 635. & Direct-burial conductors shall be Type UF, UL 493. & NA & $\begin{array}{l}\text { There are no direct burial conductors used in the CSB design. } \\
\text { Underground wiring, except for the grounding system, is encased } \\
\text { in schedule } 80 \mathrm{PVC} \text { conduit. }\end{array}$ \\
\hline $1605-2.2 .1$ & 636. & $\begin{array}{l}\text { Bonding and grounding conductors shall be ASTM } \\
\text { B1 solid, bare copper for sized No. } 8 \text { AWG and } \\
\text { smaller and shall be ASTM B8 Class B stranded } \\
\text { copper for wire sized No. } 6 \text { AWG and larger. }\end{array}$ & $\mathrm{C}$ & $\begin{array}{l}\text { Bonding and grounding conductors are solid copper for No. } 8 \\
\text { AWG and smaller and stranded copper for No. } 6 \text { AWG and larger. } \\
\text { Bonding and grounding conductors are bare or with type XHHW } \\
\text { or THWN insulation. ASTM B1 and ASTM B8 requirements are } \\
\text { met. } \\
\text { DBD: Section 5, Electrical, paragraph 5.17.1(3) }\end{array}$ \\
\hline
\end{tabular}




\section{Canister Storage Building Compliance Assessment \\ DOE Order 6430.1A, General Design Criteria}

HNF-4742, Rev. 0

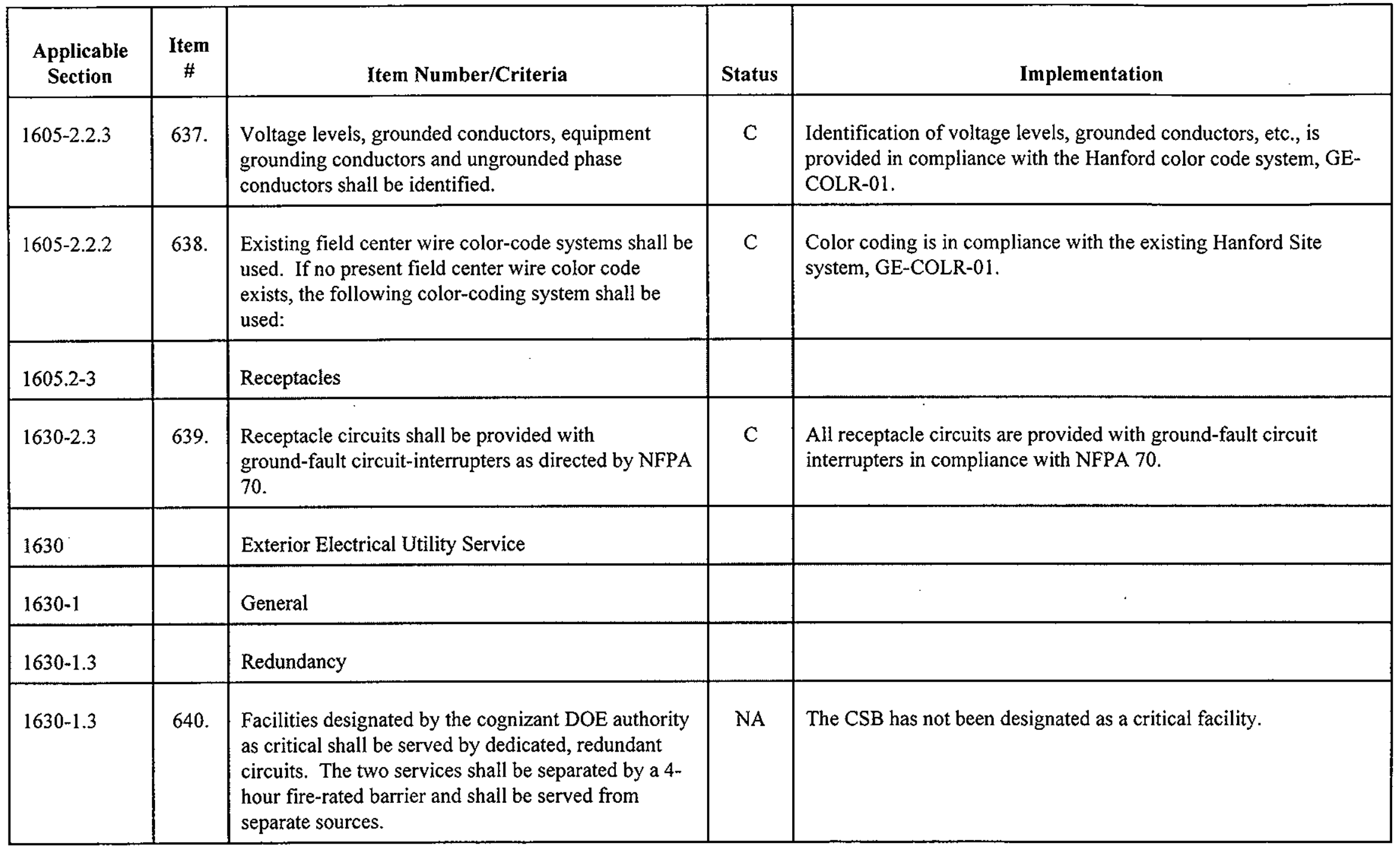




\section{Canister Storage Building Compliance Assessment \\ DOE Order 6430.1A, General Design Criteria}

HNF-4742, Rev. 0

\begin{tabular}{|c|c|c|c|c|}
\hline $\begin{array}{l}\text { Applicable } \\
\text { Section }\end{array}$ & $\begin{array}{l}\text { Item } \\
\#\end{array}$ & Item Number/Criteria & Status & Implementation \\
\hline $1630-2$ & & Supply Equipment and Facilities & & \\
\hline $1630-2.2$ & & Power Supply Lines & & \\
\hline $1630-2.2 .1$ & & General & & \\
\hline $1630-2.2 .1$ & 643. & $\begin{array}{l}\text { Line location shall be established in accordance with } \\
\text { clearance requirements stated in ANSI C } 2 \text { and shall } \\
\text { be routed within established rights-of-way for each } \\
\text { facility. }\end{array}$ & $\mathrm{C}$ & $\begin{array}{l}\text { Hanford Utilities organization established line location for the } \\
\text { CSB. The ANSI C } 2 \text { standard was used in designing the line } \\
\text { location for the CSB. }\end{array}$ \\
\hline $1630-2.2 .1$ & 644. & $\begin{array}{l}\text { Minimum rights-of-way shall extend } 5 \text { feet beyond } \\
\text { outside conductors. }\end{array}$ & $\mathrm{C}$ & $\begin{array}{l}\text { Hanford Utilities has complied with this item. See response to } \\
\text { item \#643. }\end{array}$ \\
\hline $1630-2.3$ & & Substations and Switching Stations & & \\
\hline
\end{tabular}




\section{Canister Storage Building Compliance Assessment \\ DOE Order 6430.1A, General Design Criteria}

HNF-4742, Rev. 0

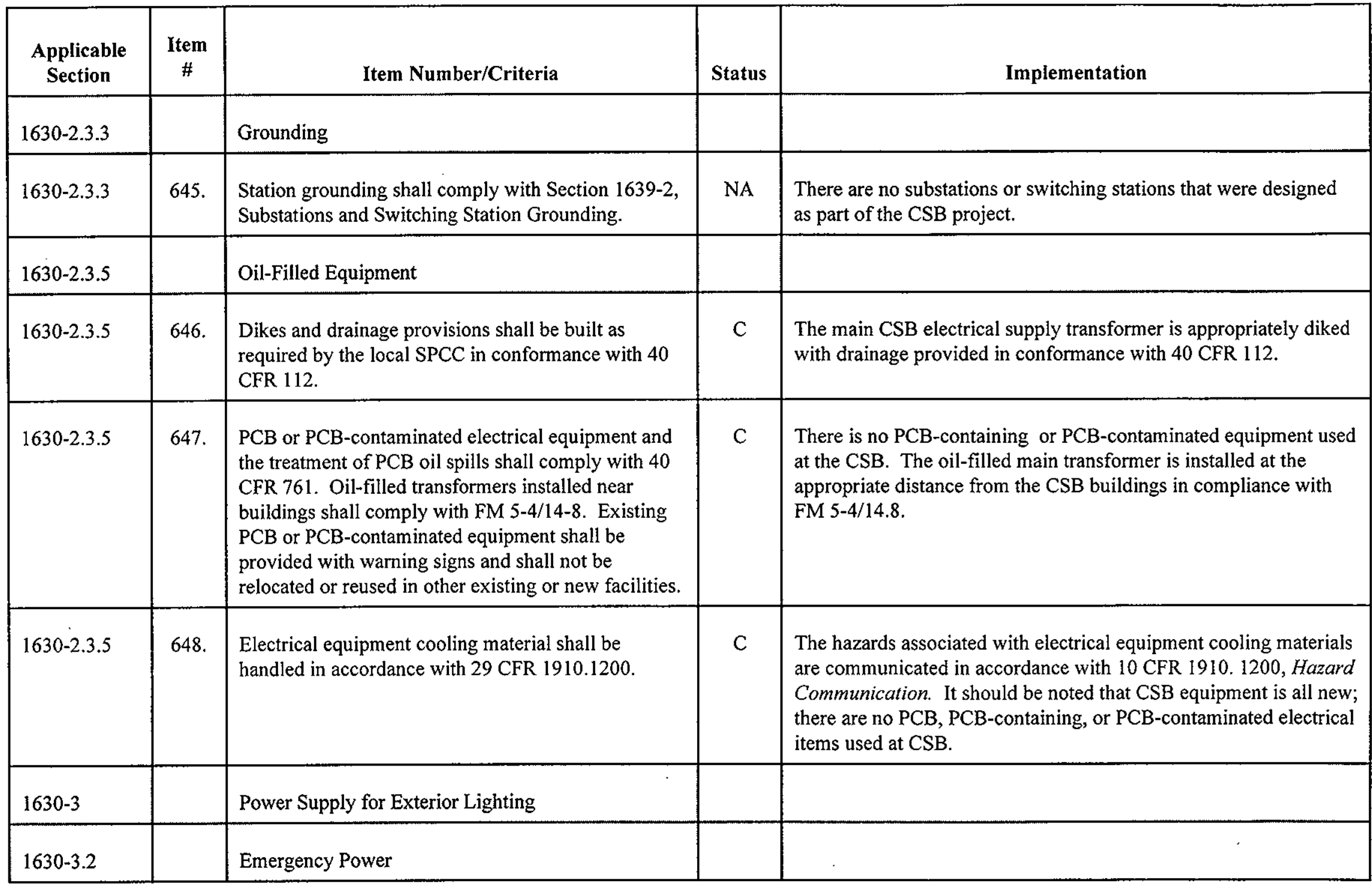




\section{Canister Storage Building Compliance Assessment DOE Order 6430.1A, General Design Criteria}

HNF-4742, Rev. 0

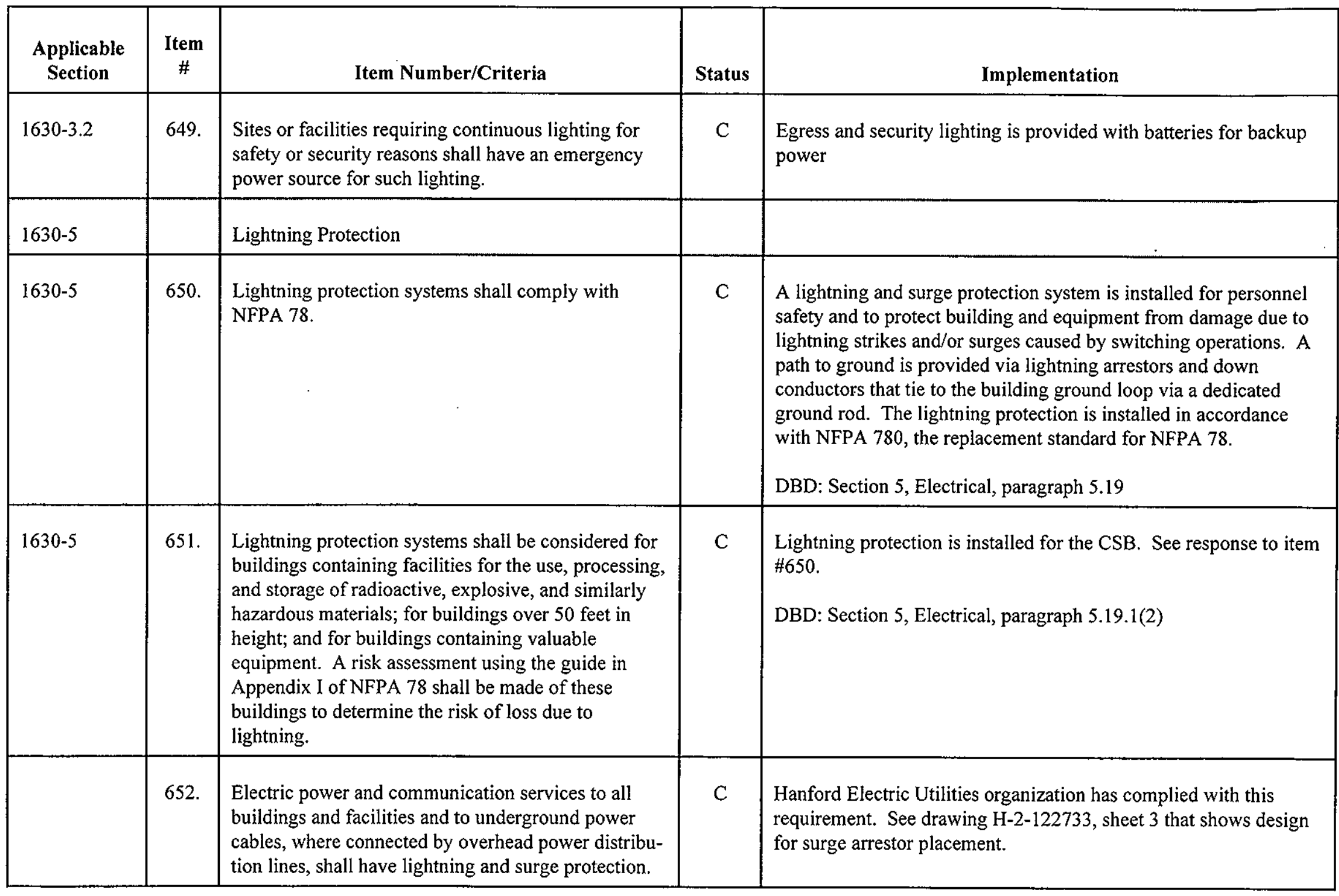




\section{Canister Storage Building Compliance Assessment \\ DOE Order 6430.1A, General Design Criteria}

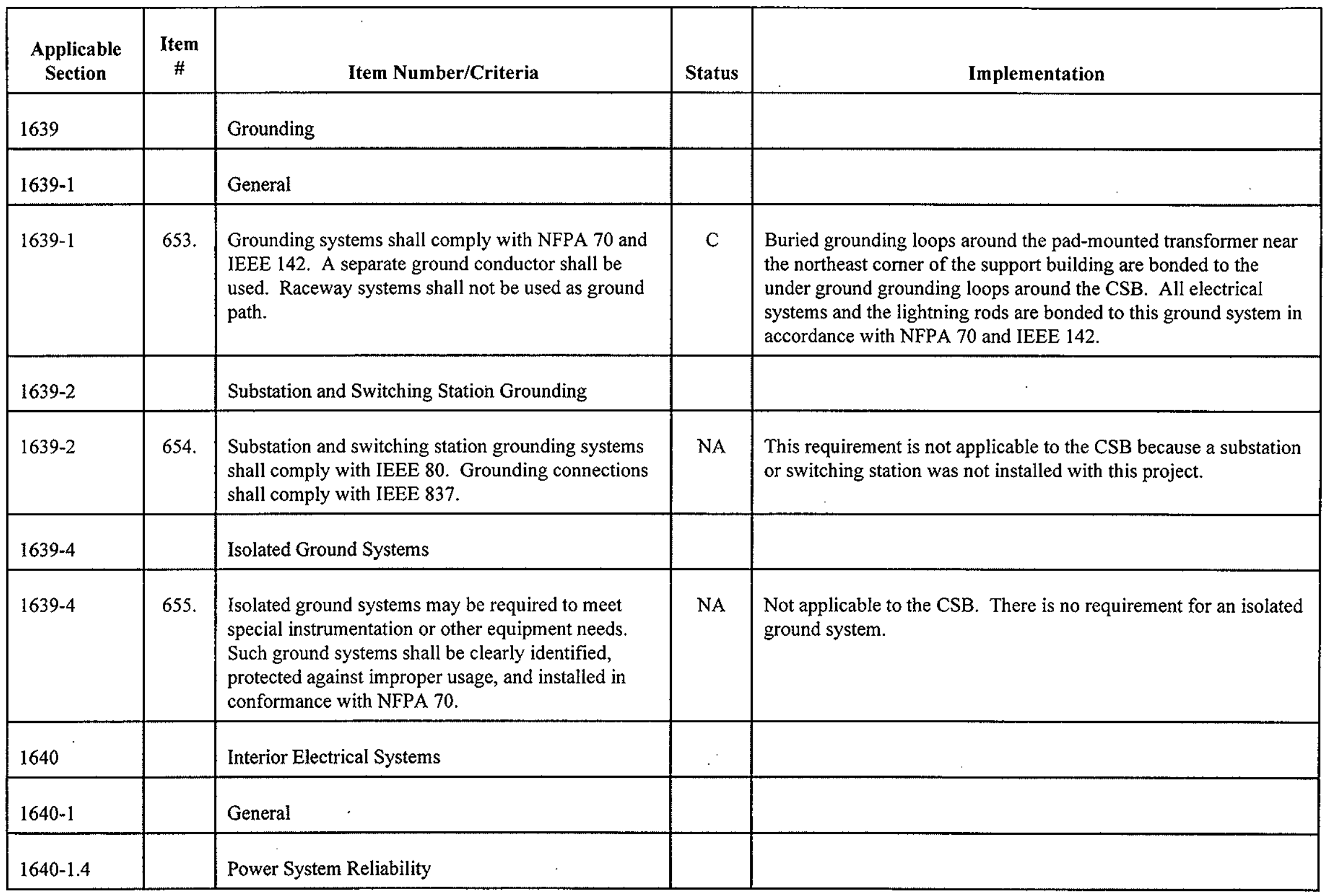




\section{Canister Storage Building Compliance Assessment \\ DOE Order 6430.1A, General Design Criteria}

HNF-4742, Rev. 0

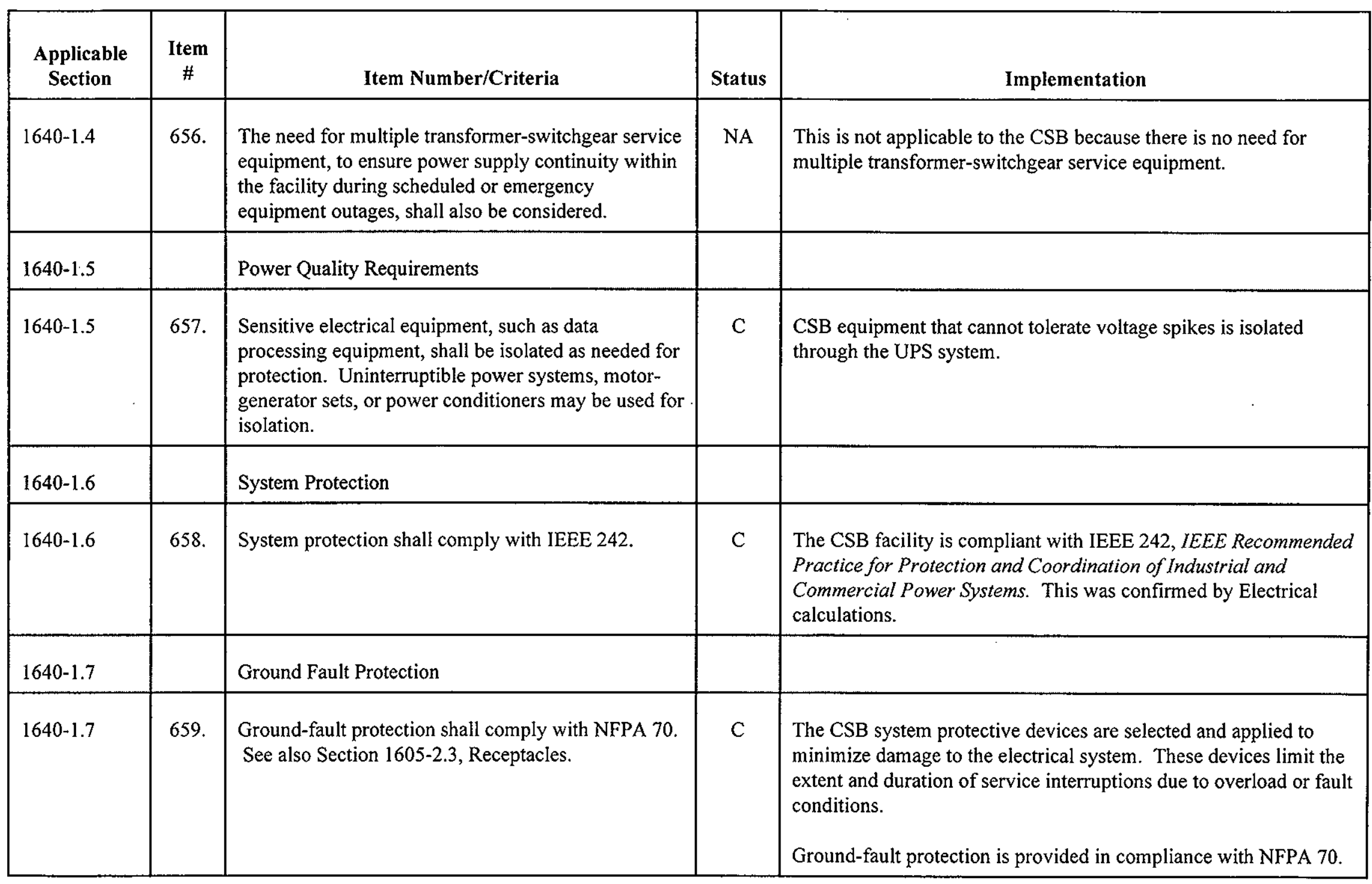




\section{Canister Storage Building Compliance Assessment \\ DOE Order 6430.1A, General Design Criteria}

HNF-4742, Rev. 0

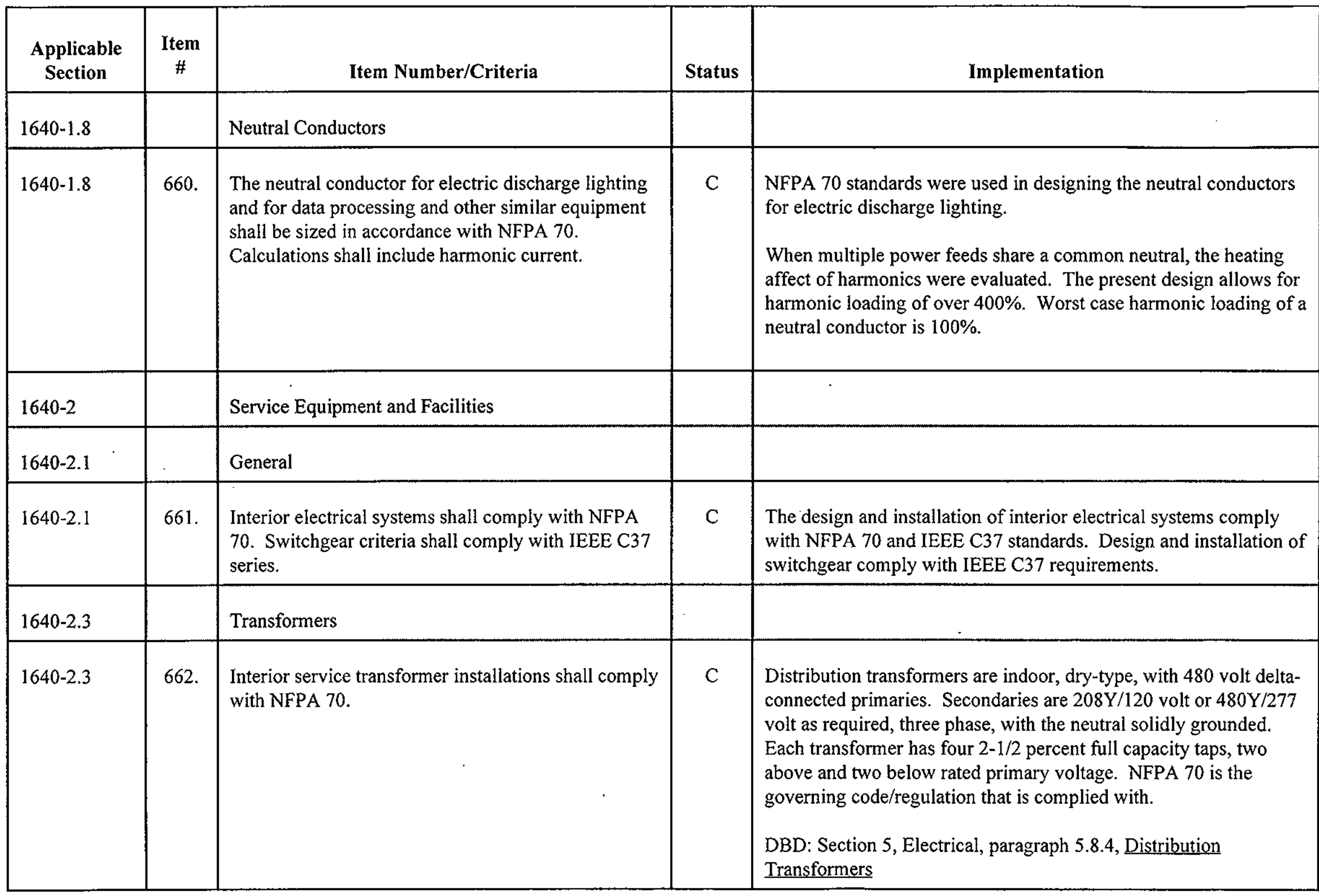




\section{Canister Storage Building Compliance Assessment \\ DOE Order 6430.1A, General Design Criteria}

\begin{tabular}{|c|c|c|c|c|}
\hline $\begin{array}{l}\text { Applicable } \\
\text { Section }\end{array}$ & $\begin{array}{l}\text { Item } \\
\#\end{array}$ & Item Number/Criteria & Status & Implementation \\
\hline $1640-2.4$ & & Motors & & \\
\hline $1640-2.4$ & 665. & $\begin{array}{l}\text { Motors shall comply with NEMA MG-1, except that } \\
\text { hermetic refrigerant motor compressors shall comply } \\
\text { with UL } 984 \text {. }\end{array}$ & C & $\begin{array}{l}\text { Motors, incorporated into the CSB facility design, comply with } \\
\text { NEMA MG-1, squirrel-cage induction type, with starting and } \\
\text { running characteristics coordinated with the driven machine and } \\
\text { the motor control equipment. The chiller motor for the } \\
\text { sampling/weld stations is UL } 984 \text { compliant. } \\
\text { DBD: Section 5, Electrical, paragraph 5.9, Motors }\end{array}$ \\
\hline $1640-2.5$ & & Motor Control & & \\
\hline $1640-2.5$ & 666. & $\begin{array}{l}\text { Control equipment shall comply with the NEMA ICS } \\
\text { standards and UL } 508 \text {. }\end{array}$ & $\mathrm{C}$ & $\begin{array}{l}\text { The motor control centers comply with NEMA Class 1, Type B } \\
\text { wiring per NEMA ICS2, Part ICS2-322. All electrical equipment } \\
\text { is UL labeled. } \\
\text { DBD: Section 5, Electrical, paragraph 5.2, Codes and Standards } \\
\text { Motor Control Centers Specification: W-379-C-CSB-16482 }\end{array}$ \\
\hline
\end{tabular}




\section{Canister Storage Building Compliance Assessment DOE Order 6430.1A, General Design Criteria}

\begin{tabular}{|c|c|c|c|c|}
\hline $\begin{array}{l}\text { Applicable } \\
\text { Section }\end{array}$ & $\begin{array}{c}\text { Item } \\
\#\end{array}$ & Item Number/Criteria & Status & Implementation \\
\hline $1640-2.5$ & 668. & $\begin{array}{l}\text { Control devices shall be of adequate voltage and } \\
\text { current rating for the duty to be performed. Pilot } \\
\text { control circuits shall operate with one side grounded, } \\
\text { at no greater than } 120 \text { volts. }\end{array}$ & $\mathrm{C}$ & $\begin{array}{l}\text { The general requirement for control devices is for the normal, } \\
\text { standby and emergency uninterruptible power supply distribution } \\
\text { systems to meet a minimum design power factor of } 0.95 \text {, which } \\
\text { includes motors and variable speed controllers. } \\
\text { Pilot control circuits are designed to operate with one side } \\
\text { grounded, at no greater than } 120 \text { volts. (See Specification Section } \\
16482 \text { ) } \\
\text { DBD: Section 5, Electrical, paragraph } 5.10 \\
\text { DBD: Section 5, Electrical, paragraph } 5.4 .7(1)\end{array}$ \\
\hline $1640-2.5$ & 669. & $\begin{array}{l}\text { Where control power transformers are required, they } \\
\text { shall be located inside the associated motor starter } \\
\text { housing, shall be protected against faults and } \\
\text { overload by properly sized over- current devices, and } \\
\text { shall be of sufficient capacity to serve all devices } \\
\text { connected to them without overload. }\end{array}$ & C & $\begin{array}{l}\text { Power control transformers are mounted inside the associated } \\
\text { motor starter housings on the removable unit with no wiring } \\
\text { behind the unit. } \\
\text { Control transformers are connected to alternate phases of control } \\
\text { center power buses to provide balancing of single phase loads. } \\
\text { Control transformers are provided one standard size larger than is } \\
\text { required for control devices, this provides extra protection from } \\
\text { overloads. } \\
\text { Specification W-379-C-CSB-16482B, Motor Control Centers }\end{array}$ \\
\hline
\end{tabular}




\section{Canister Storage Building Compliance Assessment \\ DOE Order 6430.1A, General Design Criteria}

HNF-4742, Rev. 0

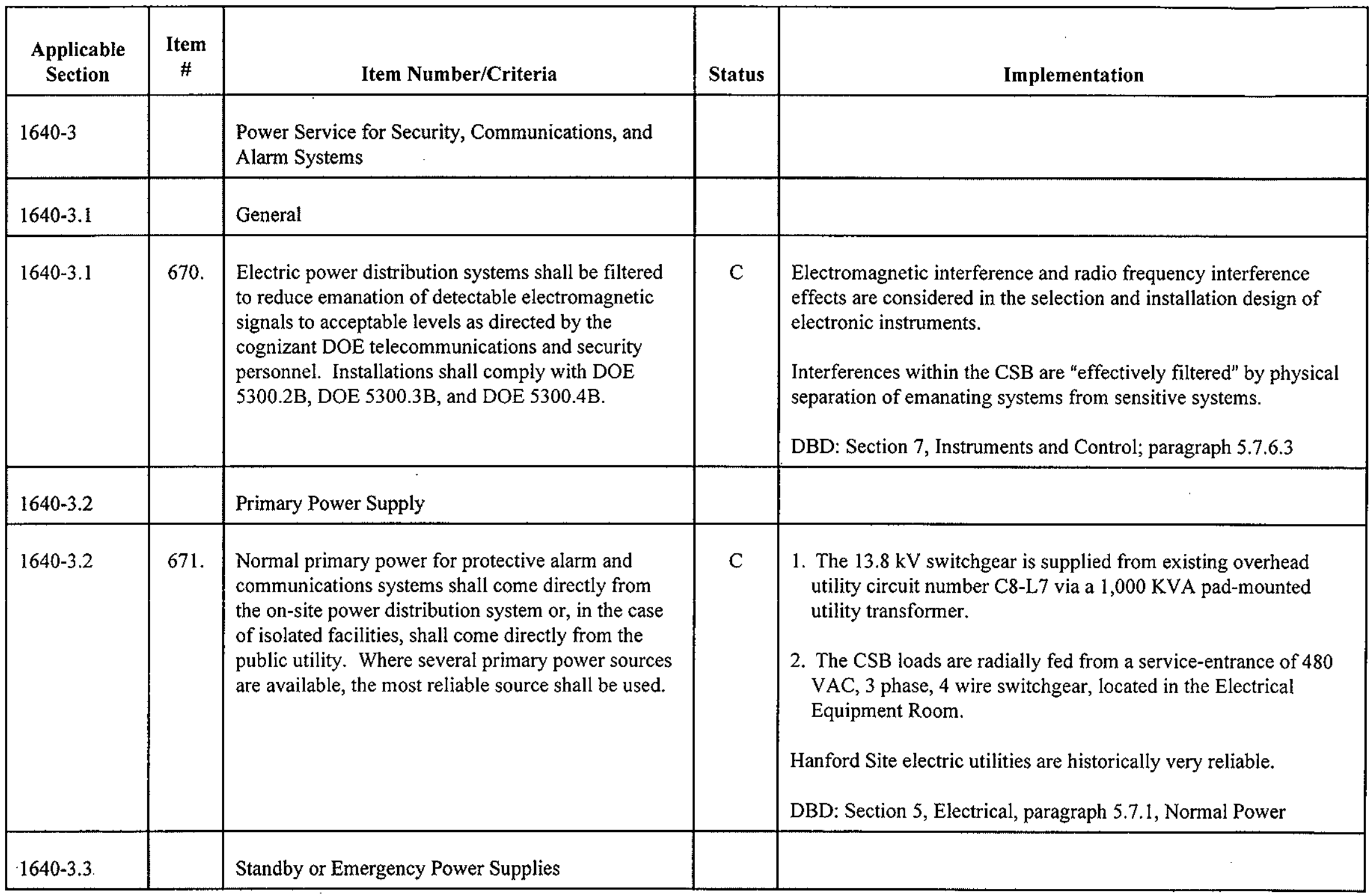




\section{Canister Storage Building Compliance Assessment \\ DOE Order 6430.1A, General Design Criteria}

HNF-4742, Rev. 0

\begin{tabular}{|c|c|c|c|c|}
\hline $\begin{array}{l}\text { Applicable } \\
\text { Section }\end{array}$ & $\begin{array}{c}\text { Item } \\
\#\end{array}$ & Item Number/Criteria & Status & Implementation \\
\hline $1660-1$ & & General & & \\
\hline $1660-1$ & 673. & $\begin{array}{l}\text { Standby and emergency systems shall serve loads set } \\
\text { forth in NFPA } 110 \text {. Additional standby or } \\
\text { emergency systems shall be provided to support } \\
\text { systems or equipment components whose operating } \\
\text { continuity is determined to be vital by the cognizant } \\
\text { DOE authorities for protection of health, life, } \\
\text { property, and safeguards and security systems. } \\
\text { Safety Class } 1 \text { items shall be provided with } \\
\text { emergency power. }\end{array}$ & NA & $\begin{array}{l}\text { There are no NFPA } 110 \text { loads identified for the CSB. There are no } \\
\text { active safety class systems that require electricity to perform their } \\
\text { function. }\end{array}$ \\
\hline $1660-1$ & 674. & $\begin{array}{l}\text { Optional standby systems shall be provided for } \\
\text { production process operations in cases where the } \\
\text { cognizant DOE authority determines that the process } \\
\text { will become unstable on loss of power or that a } \\
\text { severe monetary loss will result. }\end{array}$ & NA & There are no production process operations associated with CSB. \\
\hline $1660-1$ & 675. & $\begin{array}{l}\text { Uninterruptible power shall be provided for } \\
\text { equipment that cannot sustain functions through the } \\
\text { momentary power loss that occurs when an alternate } \\
\text { power source comes on line and picks up the load. } \\
\text { See Section } 1660-3 \text {, Uninterruptible Power Systems. }\end{array}$ & $\mathrm{C}$ & A $20 \mathrm{KVA}$ UPS is provided for selected electrical loads. \\
\hline
\end{tabular}




\section{Canister Storage Building Compliance Assessment DOE Order 6430.1A, General Design Criteria}

HNF-4742, Rev. 0

\begin{tabular}{|c|c|c|c|c|}
\hline $1660-1$ & 677. & $\begin{array}{l}\text { Emergency power equipment areas shall be } \\
\text { ventilated to exhaust hazardous gases (if applicable) } \\
\text { and to maintain satisfactory ambient temperatures for } \\
\text { equipment operation or personnel access. }\end{array}$ & NA & No emergency power equipment in CSB. \\
\hline $1660-1$ & 678. & $\begin{array}{l}\text { Emergency or standby power shall service fire alarm, } \\
\text { security alarm, and supervisory sensing devices } \\
\text { designated essential by the cognizant DOE authority. }\end{array}$ & NA & $\begin{array}{l}\text { No emergency power equipment in CSB. Fire and security } \\
\text { systems are backed up by local battery systems. }\end{array}$ \\
\hline $1660-1$ & 679. & $\begin{array}{l}\text { Emergency power systems are further detailed in } \\
\text { Section } 1660-99 \text {, Special Facilities. }\end{array}$ & NA & No emergency power equipment in CSB. \\
\hline $1660-2$ & & Emergency Power Systems & & \\
\hline
\end{tabular}




\section{Canister Storage Building Compliance Assessment \\ DOE Order 6430.1A, General Design Criteria}

HNF-4742, Rev. 0

\begin{tabular}{|c|c|c|c|c|}
\hline $1660-3$ & & Uninterruptible Power Systems & & \\
\hline
\end{tabular}




\section{Canister Storage Building Compliance Assessment \\ DOE Order 6430.1A, General Design Criteria}

HNF-4742, Rev. 0

\begin{tabular}{|c|c|c|c|c|}
\hline $1660-99$ & & Special Facilities & & \\
\hline $1660-99.0$ & & Nonreactor Nuclear Facilities - General & & \\
\hline
\end{tabular}




\section{Canister Storage Building Compliance Assessment \\ DOE Order 6430.1A, General Design Criteria}

HNF-4742, Rev. 0

\begin{tabular}{|c|c|c|c|c|}
\hline $\begin{array}{l}\text { Applicable } \\
\text { Section }\end{array}$ & $\begin{array}{c}\text { Item } \\
\#\end{array}$ & Item Number/Criteria & Status & Implementation \\
\hline
\end{tabular}




\section{Canister Storage Building Compliance Assessment \\ DOE Order 6430.1A, General Design Criteria}

HNF-4742, Rev. 0

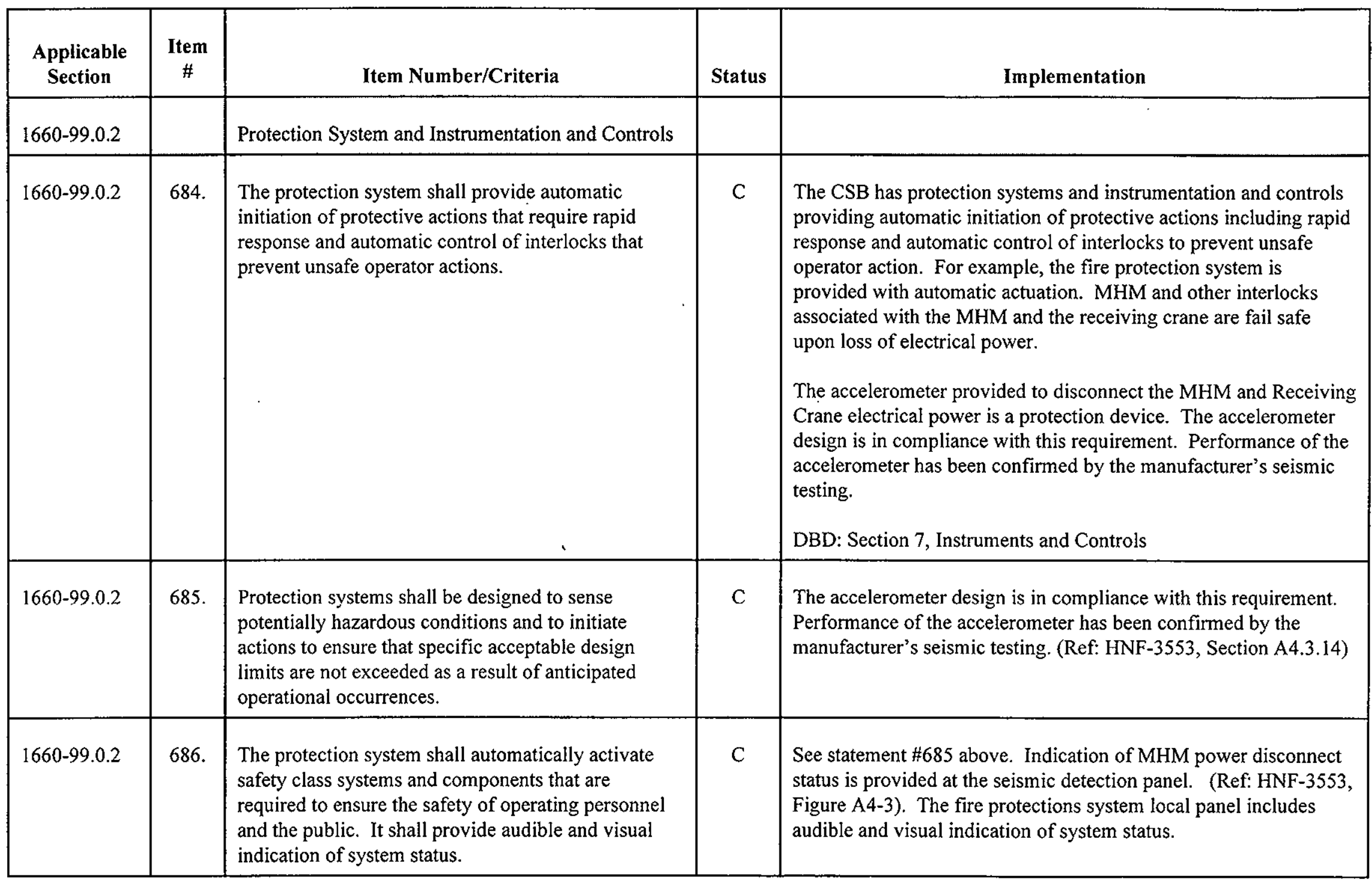




\section{Canister Storage Building Compliance Assessment \\ DOE Order 6430.1A, General Design Criteria}

HNF-4742, Rev. 0

\begin{tabular}{|c|c|c|c|c|}
\hline $\begin{array}{l}\text { Applicable } \\
\text { Section }\end{array}$ & $\begin{array}{c}\text { Item } \\
\#\end{array}$ & Item Number/Criteria & Status & Implementation \\
\hline $1660-99.0 .2$ & 688. & $\begin{array}{l}\text { The design of the protection system shall provide } \\
\text { suitable redundancy and diversity to ensure that } \\
\text { safety functions can be completed, when required, } \\
\text { and that no single failure will result in the loss of the } \\
\text { protective functions. The protection system shall be } \\
\text { designed to fail in a safe state following a component } \\
\text { or channel failure or loss of power (e.g., control air } \\
\text { or electric power). }\end{array}$ & $\mathrm{C}$ & $\begin{array}{l}\text { The Seismic Detection and MHM Power Disconnect System } \\
\text { provides redundancy and is designed to be failsafe. The } \\
\text { accelerometer design is in compliance with this requirement. } \\
\text { Performance of the accelerometer has been confirmed by the } \\
\text { manufacturer's seismic testing. (Ref: HNF-3553, Section A4.3.14) }\end{array}$ \\
\hline
\end{tabular}




\section{Canister Storage Building Compliance Assessment \\ DOE Order 6430.1A, General Design Criteria}

HNF-4742, Rev. 0

\begin{tabular}{|c|c|l|c|c|}
\hline $\begin{array}{c}\text { Applicable } \\
\text { Section }\end{array}$ & $\begin{array}{c}\text { Item } \\
\text { \# }\end{array}$ & \multicolumn{1}{|c|}{ Item Number/Criteria } & Status & Implementation \\
\hline $1660-99.0 .2$ & 690. & $\begin{array}{l}\text { Safety class instrumentation and control systems } \\
\text { shall provide audible and visual alarms so that the } \\
\text { operator can take timely corrective actions to ensure } \\
\text { the safety of operating personnel and the public. }\end{array}$ & See statement \#689 above \\
\hline $1660-99.0 .2$ & 691. & $\begin{array}{l}\text { The safety class instrumentation shall be designed to } \\
\text { monitor safety related variables and safety class } \\
\text { systems over expected ranges for normal operation, } \\
\text { anticipated operational occurrences, DBA } \\
\text { conditions, and for safe shutdown. Safety class } \\
\text { controls shall be provided when they are necessary to } \\
\text { control these variables. }\end{array}$ & C & $\begin{array}{l}\text { There is no safety class instrumentation required to monitor safety- } \\
\text { related variables or safety class systems in the CSB. The only } \\
\text { Safety Class control system in the CSB utilizes accelerometers to } \\
\text { trip power to the MHM upon actuation caused by a 1/2 SSE } \\
\text { earthquake. Local indication of accelerometer status is provided. } \\
\text { (Ref: HNF-3553, Section A4.3.14). }\end{array}$ \\
\hline $1660-99.0 .2$ & 692. & $\begin{array}{l}\text { The design of safety class instrumentation and } \\
\text { controls shall provide suitable redundancy and } \\
\text { diversity to ensure that safety functions can be } \\
\text { completed, when required, and that no single failure } \\
\text { will result in the loss of the protective functions. }\end{array}$ & C & $\begin{array}{l}\text { See item \#691. Safety class MHM interlocks provide needed } \\
\text { redundancy and diversity to ensure that the MHM is safely shut } \\
\text { down when required and that no single failure will result in the loss } \\
\text { of the protective functions. (Ref: HNF-3553, Section A4.3.14) }\end{array}$ \\
\hline
\end{tabular}




\section{Canister Storage Building Compliance Assessment DOE Order 6430.1A, General Design Criteria}

HNF-4742, Rev. 0

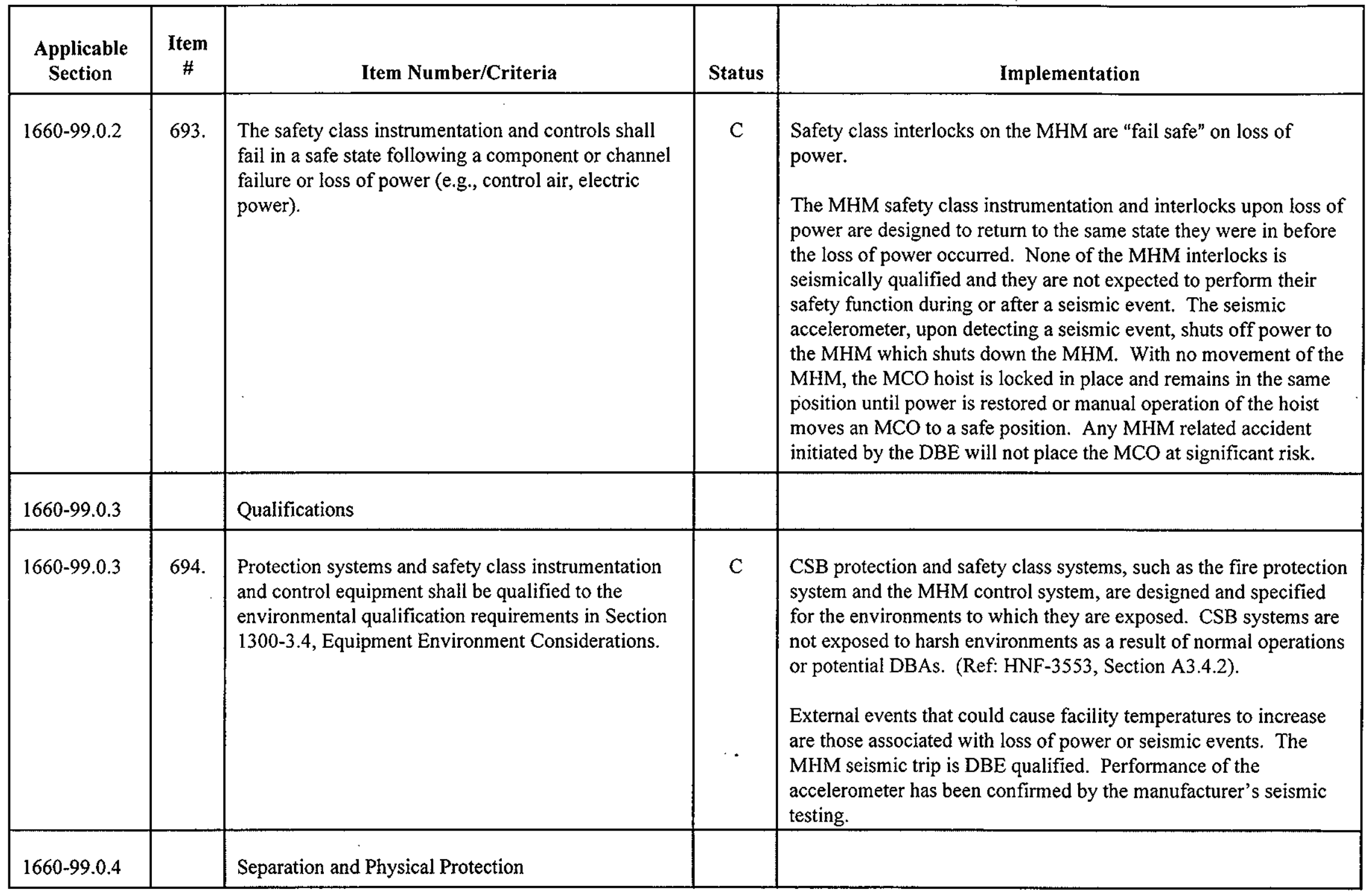




\section{Canister Storage Building Compliance Assessment \\ DOE Order 6430.1A, General Design Criteria}

HNF-4742, Rev. 0

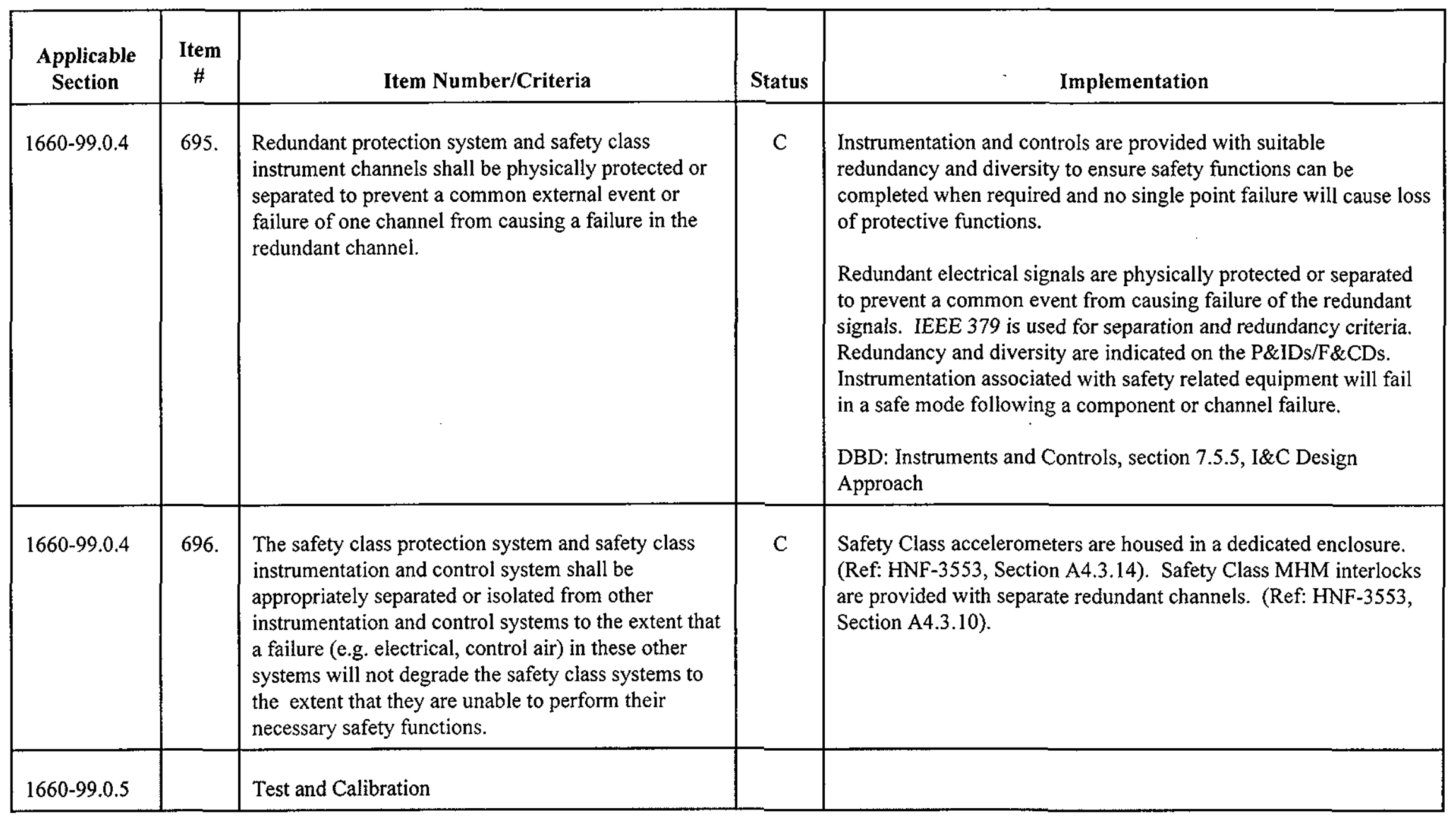




\section{Canister Storage Building Compliance Assessment DOE Order 6430.1A, General Design Criteria}

HNF-4742, Rev. 0

\begin{tabular}{|c|c|c|c|c|}
\hline $\begin{array}{l}\text { Applicable } \\
\text { Section }\end{array}$ & $\begin{array}{c}\text { Item } \\
\#\end{array}$ & Item Number/Criteria & Status & Implementation \\
\hline $1660-99.0 .5$ & 698. & $\begin{array}{l}\text { The design shall allow periodic testing of protective } \\
\text { functions to determine whether failure or loss of } \\
\text { redundancy may have occurred. }\end{array}$ & $\mathrm{C}$ & See statement $\# 697$ above. \\
\hline $1660-99.0 .7$ & & Control Areas & & \\
\hline
\end{tabular}




\section{Canister Storage Building Compliance Assessment \\ DOE Order 6430.1A, General Design Criteria}

HNF-4742, Rev. 0

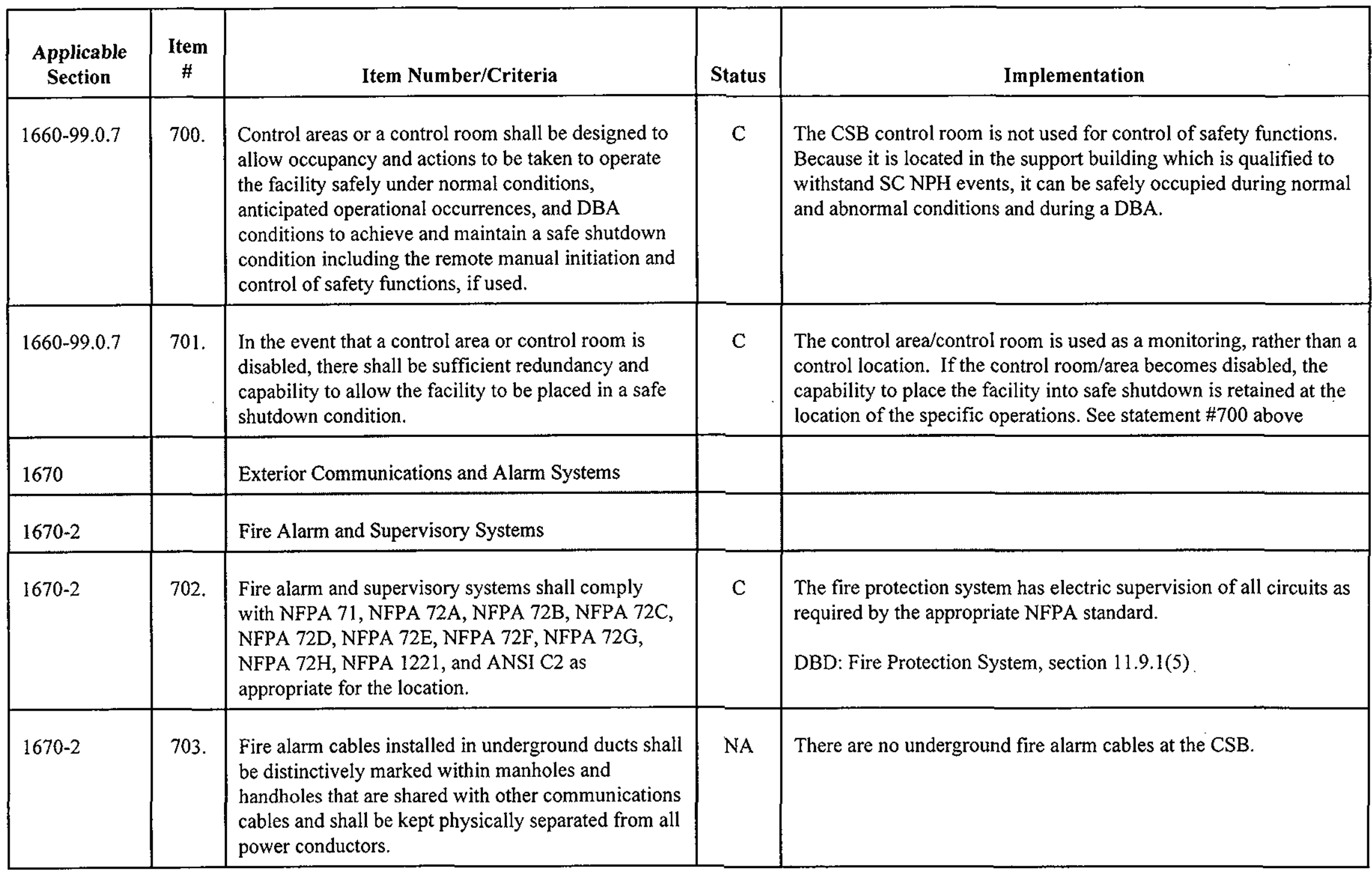




\section{Canister Storage Building Compliance Assessment}

HNF-4742, Rev. 0 DOE Order 6430.1A, General Design Criteria

\begin{tabular}{|l|c|l|c|l|}
\hline $\begin{array}{c}\text { Applicable } \\
\text { Section }\end{array}$ & $\begin{array}{c}\text { Item } \\
\text { I }\end{array}$ & \multicolumn{1}{|c|}{ Item Number/Criteria } & Status & Implementation \\
\hline $1670-2$ & 704. & $\begin{array}{l}\text { Exterior fire alarm pull boxes and emergency- } \\
\text { reporting telephones shall be installed in } \\
\text { weatherproof housings manufactured specifically for } \\
\text { the mechanism. }\end{array}$ & $\begin{array}{l}\text { There are no exterior fire alarm pull boxes or emergency } \\
\text { telephones at the CSB. }\end{array}$ \\
\hline
\end{tabular}




\section{DISTRIBUTION SHEET}

\begin{tabular}{|c|c|c|c|c|c|}
\hline $\begin{array}{l}\text { To } \\
\text { Distribution }\end{array}$ & \multicolumn{3}{|c|}{$\begin{array}{l}\text { From } \\
\text { Nuclear Safety } \\
\end{array}$} & \multicolumn{2}{|l|}{$\begin{array}{l}\text { Page } 1 \\
\end{array}$} \\
\hline \multirow{2}{*}{\multicolumn{4}{|c|}{$\begin{array}{l}\text { Project Title / Work Order } \\
\text { HNF-4742, Rev } 0 \\
\text { Canister Storage Building Compliance Assessment, DOE 6430.1A, } \\
\text { General Design Criteria }\end{array}$}} & \multicolumn{2}{|l|}{ EDT No. 626885} \\
\hline & & & & \multicolumn{2}{|l|}{ ECN No. N/A } \\
\hline Name & MSIN & $\begin{array}{l}\text { Text with } \\
\text { All Attach. }\end{array}$ & $\begin{array}{l}\text { Text } \\
\text { Only }\end{array}$ & $\begin{array}{l}\text { Attach/Appendix } \\
\text { Only }\end{array}$ & EDT/ECN Only \\
\hline G. D. Bazinet & S8-07 & $X$ & & & \\
\hline R. B. Bendixsen & $\mathrm{R} 3-26$ & $\mathrm{X}$ & & & \\
\hline D. M. Black & $\mathrm{R} 3-86$ & $X$ & & & \\
\hline A. S. Daughtridge & $\mathrm{R} 3-86$ & $X$ & & & \\
\hline L. J. Garvin & $\mathrm{R} 3-26$ & $\mathrm{X}$ & & & \\
\hline S. B. Harrington (5) & R3-26 & $X$ & & & \\
\hline P. G. LeRoy & R3-11 & $\mathrm{X}$ & & & \\
\hline
\end{tabular}

